\title{
Information asymmetry and sustainability in real estate markets
}

Citation for published version (APA):

Holtermans, R. (2016). Information asymmetry and sustainability in real estate markets. [Doctoral Thesis, Maastricht University]. Datawyse / Universitaire Pers Maastricht. https://doi.org/10.26481/dis.20160623rh

Document status and date:

Published: 01/01/2016

DOI:

10.26481/dis.20160623rh

Document Version:

Publisher's PDF, also known as Version of record

\section{Please check the document version of this publication:}

- A submitted manuscript is the version of the article upon submission and before peer-review. There can be important differences between the submitted version and the official published version of record.

People interested in the research are advised to contact the author for the final version of the publication, or visit the DOI to the publisher's website.

- The final author version and the galley proof are versions of the publication after peer review.

- The final published version features the final layout of the paper including the volume, issue and page numbers.

Link to publication

\footnotetext{
General rights rights.

- You may freely distribute the URL identifying the publication in the public portal. please follow below link for the End User Agreement:

www.umlib.nl/taverne-license

Take down policy

If you believe that this document breaches copyright please contact us at:

repository@maastrichtuniversity.nl

providing details and we will investigate your claim.
}

Copyright and moral rights for the publications made accessible in the public portal are retained by the authors and/or other copyright owners and it is a condition of accessing publications that users recognise and abide by the legal requirements associated with these

- Users may download and print one copy of any publication from the public portal for the purpose of private study or research.

- You may not further distribute the material or use it for any profit-making activity or commercial gain

If the publication is distributed under the terms of Article $25 \mathrm{fa}$ of the Dutch Copyright Act, indicated by the "Taverne" license above, 


\title{
Information Asymmetry and Sustainability in Real Estate Markets
}

\author{
Rogier Holtermans \\ Maastricht University School of Business and Economics \\ Maastricht, the Netherlands
}

A thesis submitted for the degree of

Doctor of Philosophy at Maastricht University

June 23, 2016 
All rights reserved. No part of this publication may be reproduced, stored in a retrieval system, or transmitted, in any form, or by any means, electronic, mechanical, photocopying, recording or otherwise, without the prior permission in writing from the author.

Cover design by Marco Jeurissen (http://www . marcojeurisssen.nl).

This book was typeset using ATEX. .

ISBN 9789461595805

Printed by Datawyse / Universitaire Pers Maastricht 


\title{
Information Asymmetry and Sustainability in Real Estate Markets
}

\author{
DISSERTATION \\ to obtain the degree of Doctor at Maastricht University, \\ on the authority of Prof. dr. L.L.G. Soete, Rector Magnificus, \\ in accordance with the decision of the Board of Deans, \\ to be defended in public \\ on Thursday, June 23, 2016, at 4:00 p.m.
}

by

Rogier Holtermans 
Promotor:

Prof. dr. Piet Eichholtz

Co-promotor:

Dr. Nils Kok

Assessment committee:

Prof. dr. Jaap Bos, Chairman

Prof. dr. Rob Bauer

Prof. dr. Dirk Brounen (Tilburg University)

Dr. Chris Pyke (GRESB) 
Voor mijn ouders 
Zum Glück gehört, dass man irgendwann beschließt, zufrieden zu sein. 


\section{Acknowledgements}

Maastricht, June 1, 2016

Some compare doing a $\mathrm{PhD}$ to a personal development track. That seems pretty accurate to me. Writing this piece is the final step in completing "The Book," and the journey that accompanied it. The last few years have been a remarkable experience, and reflecting back on that period is humbling. I have learned that there is no such thing as the solitary researcher; many have contributed to my dissertation, and for their guidance and support I am deeply grateful.

My first words of thanks go to my promotor, Piet Eichholtz. Piet, I am greatly indebted to you. It is safe to say that without you this dissertation would not have been written, and I probably would have been lost to "the dark side." You taught me countless lessons, including life lessons reaching far beyond research. Your enthusiasm has been and always will be a great source of inspiration. You are a gifted mentor, and together with Nils I could not have wished for a better team of academic supervisors. Nils, you have been like an elder brother to me, always encouraging me to take on new challenges. You set the bar extremely high in everything you undertake in life, which makes for an exceptional role model. ${ }^{1}$ The only caveat is that it is almost impossible to keep up with and follow in your footsteps. ${ }^{2}$

During my doctoral program I had the opportunity to visit at some outstanding institutions. Chris Pyke and the research team of the U.S. Green Building Council welcomed me for three months in the summer of 2013 in Washington, DC. Chris, you were a great host and made sure I had everything I needed to make my stay both productive and fun. I am very pleased that you are part of my assessment committee and grateful for the time you invested in my academic development. Many thanks also go out to Albert Saiz and David Geltner for hosting me for a semester at the MIT Center for Real Estate. You have an incredible group at the Center, including the most hospitable support staff. David, you are one of the kindest and brightest academics I have come to know: thank you for introducing me to the world of delicious donuts. The invitation to spend a semester at the University of Southern California was kindly extended by Matt Kahn. Matt, I am so thankful that you stuck your neck out to host a doctoral student that you barely knew. You are among the brightest economists with which I have had the good fortune to work, and your method of returning to the fundamental economic questions has been key in shaping my research. I am also very grateful to Richard and Rodney of the Lusk Center for Real Estate for having me at Price, and I very much look forward to joining your team.

In addition, I would like to thank the other members of my assessment committee, Jaap Bos, Rob Bauer, and Dirk Brounen, for their time and energy in providing me with invaluable feedback on my manuscript. Jaap, it has been an honor to be part of the Finance Department

\footnotetext{
${ }^{1}$ I am assuming this has been said before...

2 ...maybe this not.
} 
and I am sure it will thrive under your auspices. Rob, in addition to Piet and Nils, you showed me that it is possible to combine a great academic career with close ties to the industry; I admire you for that. Dirk, I got to know you as part of the larger Maastricht real estate family, and you always provided a valuable outside-in perspective on various matters. I have fond memories of our research day in front of the wood stove at your beautiful home.

Along the way I was fortunate enough to have great coauthors who exposed me to different aspects of research. Andrea, during our collaboration on several projects, you stressed the power of combining the bigger picture with a sound estimation strategy. The fact that I had such a great time at MIT is, to a large extent, due to you. You made me feel welcome and at home, and were always available for advice or simply a pick me up. ${ }^{3}$ Erkan, it has been great working together on our papers and combined we make a very creative data matching team. It is wonderful to see that you and your family are doing so well in Istanbul, and thank you for showing me your amazing city.

Going to work with a smile is not difficult when you are part of such a great team. The Finance Department consists of a truly wonderful group of people that feels like family. ${ }^{4}$ The ladies of the secretariat are the heart of this family and have assisted me in many matters, ranging from travel arrangements to administrative issues, but most importantly also provided for a nice chat whenever needed. Carina, Cécile, Els and Francien: you are the ones that keep the boat afloat. Although you will have to say goodbye to the "Kneuterkaart" soon, I will be back more often than you would have hoped. Oana, Hang, Juan and Patrick: you have been great office mates, and many thanks for good times go out to all colleagues of the department, both past and present.

Empirical research without good information is not possible, several organizations have contributed to the studies in this dissertation. ${ }^{5}$ I kindly thank CBRE, CoStar Realty Information, the Dutch Land Registry, the Dutch Realtors Association, and the U.S. Green Building Council for providing me with the information needed to perform my research. Similar to data, access to funding is also key. I would like to thank CBRE, the Dutch Enterprise Agency and the Real Estate Research Institute for their generous support.

Of course there is also a world outside of work, and many friends have provided support throughout the process in varying capacities. I wish there was enough space to thank everyone who shaped me, but a few bear highlighting. A special word of thanks go to my paranymphs Simone and Tim. Simone, we met through the department, and I am very happy we have been able to stay in touch ever since. You are one of the most kind and fun people I know and it has been a joy getting to know you better. I admire the ease with which you combine a global academic career and strong roots in your social circle. Tim, you have been a part of this endeavor from the beginning, and whenever we get the chance to meet it always feels like it was only yesterday that we last saw each other. We have such great times discussing any aspect of life and diligently supporting the local bar and restaurant industry wherever we go. ${ }^{6}$ Marius, the year we spent together at the Vijfharingenstraat was great. You showed me how important it is to put yourself in someone else's shoes. Petran, we have known each other since high school

\footnotetext{
${ }^{3}$ Here is hoping Mars stays out of retrograde for a while.

${ }^{4}$ Gossip included.

${ }^{5}$ In case we paid you for your data, you unfortunately did not make the cut here.

${ }^{6}$ Predominantly Maastricht, but we do tend to take it international.
} 
and nothing distinguishes a great friend like their unwavering support. From long Christmas dinners with your family to road tripping in California, a pleasure as always.

Ik ben geworden tot wie ik ben door mijn familie. Mam en Pap, zonder jullie eindeloze steun en vertrouwen was het me nooit gelukt om dit proefschrift tot een succesvol einde te brengen. Opgroeien met de volledige vrijheid om je eigen interesses en doelen te ontplooien is het mooiste dat er is. Mam, je bent ontzettend zorgzaam, en ik kan je niet genoeg bedanken voor alles wat je voor me gedaan hebt. Pap, ik denk dat jij eerder wist dat ik deze uitdaging aan zou gaan dan ikzelf. Ik waardeer onze gesprekken over de meest uiteenlopende zaken enorm, en stel je adviezen zeer op prijs. Gertjan, jouw nuchtere kijk op de wereld en de inzichten die dit brengt hebben me veel geholpen en zullen voor mij in de toekomst zeker nog vaker van grote waarde zijn. Uitwaaien tussen de landerijen heeft een verfrissende en verhelderende werking, wat vaak een welkome afleiding heeft geboden op een (te) volle to-do list. Een grote steun is de gedachte aan jullie, mijn thuis, waar ter wereld ik me ook bevind. 



\section{Contents}

Acknowledgements $\quad$ iii

List of Figures $\quad$ xi

List of Tables $\quad$ xiii

1 Introduction 1

1.1 Information Asymmetry in the Commercial Real Estate Market . . . . . . . . . 2

1.2 The Environmental Implications of the Built Environment . . . . . . . . . . 3

2 The Effects of Owner Distance and Property Management 9

2.1 Introduction . . . . . . . . . . . . . . . . . . . 9

2.2 Local Asset Ownership and Information Access . . . . . . . . . . . . . . . . 11

2.3 Data Description . . . . . . . . . . . . . . . . . . 13

2.3 .1 Data and Source . . . . . . . . . . . . . . . . . . . 13

2.3.2 Descriptive Statistics . . . . . . . . . . . . . . . . . . . . . 14

2.3.3 Investor Proximity in the U.S. Office Markets . . . . . . . . . . . . . . 16

2.4 Empirical Framework . . . . . . . . . . . . . . . . . . . . 18

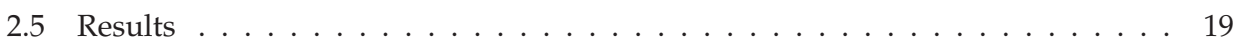

2.5.1 Proximity Premium and Distance Discount . . . . . . . . . . . . . . . . 19

2.5.2 Owner Distance and Property Management . . . . . . . . . . . . . . . 22

2.5.3 Building Quality and Property Management . . . . . . . . . . . . . . . . . . 25

2.6 Conclusion and Discussion $\ldots \ldots \ldots \ldots \ldots \ldots \ldots$

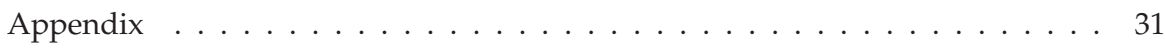

A Main Results for the 50 Largest CBSAs . . . . . . . . . . . . . . . 31

B Definition of Building Classifications . . . . . . . . . . . . . 32

C Propensity Score Weighting Procedure . . . . . . . . . . . . . . . 33

D Owner Distance Distribution Figures . . . . . . . . . . . . . . . . 42

E Impact of Property Management . . . . . . . . . . . . . . . . . . . . 44

3 Intermediation in the Commercial Real Estate Market $\quad 45$

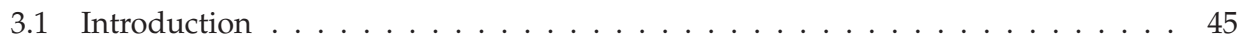

3.2 Literature . . . . . . . . . . . . . . . . . . . . . . . 47

3.3 Data and Descriptive Statistics . . . . . . . . . . . . . . 50

3.3.1 Data and Sources . . . . . . . . . . . . . . . . . . . 50

3.3.2 Descriptive Statistics . . . . . . . . . . . . . . . . . . 51 


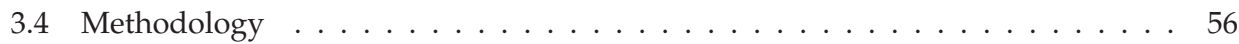

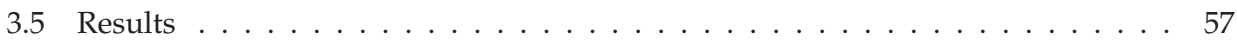

3.5.1 Rental Sample . . . . . . . . . . . . . . . . . . . . . . . . . 57

3.5 .2 Transaction Sample . . . . . . . . . . . . . . . . . . . . . . . . . . 61

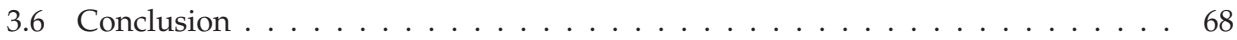

4 Environmental Certification in Commercial Real Estate $\quad 69$

4.1 Introduction . . . . . . . . . . . . . . . . . . . . . . . . . 69

4.2 Environmental Certification in Commercial Real Estate . . . . . . . . . . . . . 71

4.3 Repeated Rent Indices . . . . . . . . . . . . . . . . . . . . . 73

$4.3 .1 \quad$ Empirical Framework . . . . . . . . . . . . . . . . . . 73

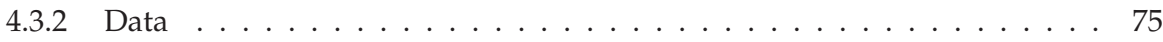

4.3 .3 Descriptive Statistics . . . . . . . . . . . . . . . . . 76

4.3.4 Environmental Certification Indices . . . . . . . . . . . . . . . . 76

4.4 Marginal Certification Effects . . . . . . . . . . . . . . . . . . . . 80

4.4 .1 Empirical Framework . . . . . . . . . . . . . . . . 80

4.4 .2 Data . . . . . . . . . . . . . . . . . . . 81

4.4 .3 Descriptive Statistics . . . . . . . . . . . . . . . . . . . . 82

4.5 Empirical Results . . . . . . . . . . . . . . . . . . . . . . . . 84

4.5 .1 Marginal Effects . . . . . . . . . . . . . . . . . . 84

4.6 Conclusion . . . . . . . . . . . . . . . . . . . . . 93

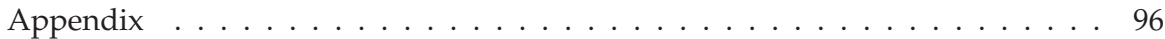

A Main Results for the Attribution Analysis . . . . . . . . . . . . . . . 96

5 Environmental Performance and the Cost of Capital 99

5.1 Introduction . . . . . . . . . . . . . . . . . . . . . . . . . . . . . . . 99

5.2 Environmental Performance and Real Estate Investments . . . . . . . . . . . 102

5.3 Data . . . . . . . . . . . . . . . . . . . . . . . . . . . 103

5.3.1 REITs and Environmentally Certified Buildings . . . . . . . . . . . 103

5.3.2 REITs and Commercial Mortgages . . . . . . . . . . . . . . . . 106

5.3 .3 REIT Bonds . . . . . . . . . . . . . . . . . . . . . . 108

5.4 Methodology . . . . . . . . . . . . . . . . . . . . . 109

5.4.1 REIT Commercial Mortgages . . . . . . . . . . . . . . . . . . . . . . . 109

5.4 .2 REIT Corporate Bonds . . . . . . . . . . . . . . . . . . . . . . 110

5.5 Empirical Findings . . . . . . . . . . . . . . . . . . . . 112

5.5.1 Commercial Mortgage Spreads and Environmental Certification . . . . 112

5.5.2 Corporate Bond Spreads and Environmental Certification . . . . . . . . 116

5.5 .3 Robustness Checks . . . . . . . . . . . . . . . . . . . . 120

5.6 Conclusion and Discussion . . . . . . . . . . . . . . . . . . . 122

Appendix . . . . . . . . . . . . . . . . . . . . . . . . 124

A The REIT Bond Market . . . . . . . . . . . . . . . . . . . . . . . . . . . . 124 
6.1 Introduction . . . . . . . . . . . . . . . . . . . . . 125

6.2 The Housing Market and the Value of Energy Efficiency . . . . . . . . . . . . . 127

6.3 The Dutch Affordable Housing Market . . . . . . . . . . . . . . . . . . . 130

6.4 Data and Descriptive Statistics . . . . . . . . . . . . . . . . . . 131

6.4 .1 Data . . . . . . . . . . . . . . . . . . . . 131

6.4 .2 Descriptive Statistics . . . . . . . . . . . . . . . . . . . . . . . . . . . . . . . . . . . . . . . . .

6.5 Method . . . . . . . . . . . . . . . . . . . . . . . 136

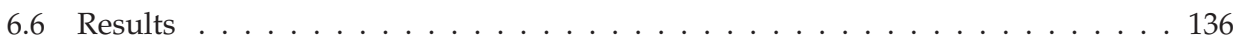

6.6.1 The Value of Energy Performance Certificates in Affordable Housing . . . . . . . . . . . . . . . . . . . . . . . . . . . . . . . . . . . . .

6.6 .2 Heterogeneous Effects . . . . . . . . . . . . . . . . . . . . 140

6.7 Conclusions and Policy Implications . . . . . . . . . . . . . . . . . 144

$\begin{array}{lll}7 & \text { Conclusion } & 147\end{array}$

8 Research Impact $\quad 151$

$\begin{array}{ll}\text { References } & 155\end{array}$

$\begin{array}{ll}\text { Curriculum Vitae } & 165\end{array}$ 



\section{List of Figures}

1.1 Household and Home Size in the U.S. (1973-2013) . . . . . . . . . . . . . . . . 2

1.2 Carbon Concentration in the Atmosphere $(1000-2004) \ldots \ldots \ldots$. . . . . . . 4

1.3 Energy Production by Fuel Type $(1800-2008) \quad \ldots \ldots \ldots$. . . . . . . . . . . . 5

1.4 Share of U.S. Energy Consumption by End-Use Sector (1949-2014) . . . . . . . . . 6

2.1 Quintiles of Number of Observations by CBSA . . . . . . . . . . . . . . . . . . . . 14

2.2 Effective Rent and Owner Distance . . . . . . . . . . . . . . . . . . . . . 20

2.3 Effective Rent, Owner Distance, and Property Management (Class B) . . . . . . . 27

C.1 Distribution of Propensity Scores . . . . . . . . . . . . . . . . . . 35

D.1 Distribution of Owner Distance, by Building Class . . . . . . . . . . . . . . . 42

D.2 Distribution of Owner Distance, by Property Management Category . . . . . . 43

3.1 Geographic Distribution of Observations . . . . . . . . . . . . . . 51

3.2 Transaction Advisors by Building Class . . . . . . . . . . . . . . . 55

4.1 The Adoption of Environmental Building Certification . . . . . . . . . . . . . 74

4.2 Rent and Occupancy Trends for Environmentally Certified and Non-Certified Buildings . . . . . . . . . . . . . . . . . . . 77

4.3 Asking Rent and Effective Rent Indices for Environmentally Certified and NonCertified Buildings . . . . . . . . . . . . . . . . . . . . 79

5.1 Portfolio Weights of Environmental Certification over Time . . . . . . . . . . . . . 104

5.2 Environmental Certification of REIT-Owned Assets by CBSA . . . . . . . . . . . 105

A.1 Number of REIT Bonds at Origination and in the Secondary Market . . . . . . . . 124

6.1 Distribution of Energy Performance Certificates . . . . . . . . . . . . . . . . 135

6.2 Transaction Value and Energy Performance Index . . . . . . . . . . . . . 143 



\section{List of Tables}

2.1 Building Characteristics . . . . . . . . . . . . . . . . 16

2.2 Non-Local Ownership and Distance . . . . . . . . . . . . . . . . . . 18

2.3 Local Owernship and Rent Value . . . . . . . . . . . . . . . . . . . . . . . . . . . 21

2.4 Local Ownership and Rent Value, by Building Class . . . . . . . . . . . . . . . . . 23

2.5 Property Management and Local Ownership . . . . . . . . . . . . . . . . . . . 24

2.6 Property Management and Local Ownership, by Building Class . . . . . . . . . 26

2.7 Property Management Categories and Local Ownership . . . . . . . . . . . . . . 29

A.1 Property Management and Local Ownership, CBSA Top 50 . . . . . . . . . . . 31

C.1 The Determinants of External Property Management . . . . . . . . . . . . 36

C.2 Building Characteristics across Propensity Score Weighting Techniques . . . . . . 37

C.3 Propensity Score Specificaitons . . . . . . . . . . . . . . . . . . . . . . . . 39

E.1 Property Management and Local Ownership . . . . . . . . . . . . . . . . . . . 44

3.1 Descriptive Statistics . . . . . . . . . . . . . . . . . . . . . . . . . . 53

3.2 Real Estate Broker Activity and Transaction Complexity . . . . . . . . . . . . . 56

3.3 Rental Level, Occupancy Rate, and Real Estate Advisor Activity . . . . . . . . . . 59

3.4 Transaction Price and Transaction Advisors Activity . . . . . . . . . . . . . . . 62

3.5 Transaction Complexity and Transaction Advisors . . . . . . . . . . . . . . . . . 64

3.6 Time on the Market and Advisor Activity . . . . . . . . . . . . . . 66

4.1 Average Annual Rental Growth for Environmentally Certified and Non-Certified Buildings . . . . . . . . . . . . . . . . . . . 80

4.2 Descriptive Statistics . . . . . . . . . . . . . . . 83

4.3 Environmental Certification, Rent, and Transaction Price . . . . . . . . . . . . . 85

4.4 Environmental Certification and Heterogeneous Price Effects . . . . . . . . . . . . 87

4.5 Certification Characteristics (Energy Star and LEED) . . . . . . . . . . . . . . . 88

4.6 Certification Characteristics and Effective Rents . . . . . . . . . . . . . . . . 90

4.7 Certification Characteristics and Transaction Prices . . . . . . . . . . . . . . 92

A.1 Environmental Certification, Building Characteristics, Rent, and Transaction Price 96

5.1 Descriptive Statistics $(2006-2014)$. . . . . . . . . . . . . . . . . . . . 107

5.2 Environmental Certification and Mortgage Spreads (2006-2014) . . . . . . . . . 113

5.3 LEED Certification Levels and Mortgage Spreads (2006-2014) . . . . . . . . . . . 115

5.4 Environmental Certification and Corporate Bond Spreads at Origination (2006-2014)116

5.5 Environmental Certification and Corporate Bond Spreads on Secondary Market $(2006-2014) \ldots \ldots \ldots \ldots \ldots \ldots$ 
5.6 Environmental Certification and Corporate Bond Spreads (2007-2014) . . . . . . 120

5.7 Debt Capacity Analysis . . . . . . . . . . . . . . . . . . . . . . . . . . . 121

6.1 Descriptive Statistics . . . . . . . . . . . . . . . . . . . . . . 133

6.2 Transaction Value and Energy Performance Certificates . . . . . . . . . . . . . 138

6.3 Transaction Value and Label Quality within the EPC Labeled Sample . . . . . . . 141 


\section{Chapter 1}

\section{Introduction}

Population growth and economic development are at the core of increasing consumption of real estate. It took about 1800 years to reach a world population of 1 billion people, in 1804, and since then the world population increased to about 7.3 billion people. Although the population growth rate is decreasing, the United Nations predicts the world population to reach a staggering 9.7 billion people in 2050. This implies that the demand for real estate will continue to increase, since all these people need a place to live, work, and play. Add to this the economic growth of developing countries, the increase in demand for real estate becomes even more apparent, as the per capita consumption of real estate tends to grow with increasing income and wealth. In Amsterdam, for example, living quarters that were occupied by large blue-collar families in the early twentieth century are now used as apartments, occupied by a one-person or small household. Another important trend, linked to economic development, is a decrease in household size. The average household size in developed countries has been decreasing gradually over the last decades. Therefore, even though the population in more developed regions is generally expected to decline after 2040, the total number of households and subsequently the demand for housing is increasing.

As an illustration of these trends, Figure 1.1 depicts the average size of newly constructed single-family homes and the average household size in the U.S., over the 1973-2013 period. This graph shows the increased consumption of space with increasing prosperity and decreasing household size over time. While the average household size has decreased from about 3 people in 1973 to 2.5 people in 2013, the average size of a newly constructed single-family home has increased from some 1,700 square feet in 1973 to almost 2,600 square feet in 2013. This implies that the average square feet of housing consumed per person in the U.S. has increased from some 550 square feet to more than 1,000 square feet over 41 years, an increase of 85 percent.

The growing importance of real estate in our everyday lives makes it important to understand the functioning of real estate markets and the broader economic implications of the built environment. An interesting development in the commercial real estate market is a shift towards more institutional real estate ownership rather than corporate real estate ownership, and these institutional portfolios are increasingly international. The question is what this shift means for the successful management of real estate portfolios. The first part of this dissertation addresses a critical element of real estate portfolio management — information asymmetry and intermediation. 
Figure 1.1: Household and Home Size in the U.S. (1973-2013)

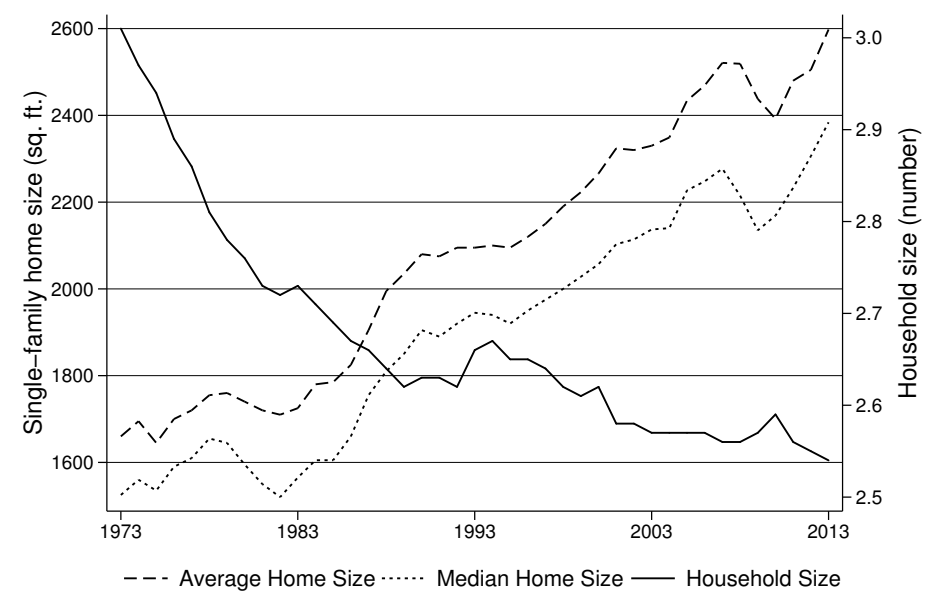

Source: U.S. Census Bureau, 2013

Another consequence of the increasing use of real estate in modern society is that the real estate sector's environmental footprint is growing. The built environment consumes a large share of energy and other natural resources and is responsible for a considerable part of total greenhouse gas emissions. These issues are the focus of the second part of my dissertation.

\subsection{Information Asymmetry in the Commercial Real Estate Market}

Over the last decades corporate real estate ownership has been decreasing and institutional ownership, through direct and indirect investments, in commercial real estate has been increasing (Brounen and Eichholtz, 2005). Due to the growing acceptance of real estate as a mainstream asset class it is important to understand the implications of this transition in light of the underlying market mechanisms.

Institutional owners use their holdings in commercial real estate as an investment, as compared to corporate owners, which employ the assets they own to support their operations. Although this difference may seem trivial and obvious, key is that institutional investors usually hold a globally diversified portfolio of multiple assets across different asset classes. The riskreduction benefits of such portfolio diversification strategy have been well documented in the finance literature (Markowitz, 1952). In contrast to the documented benefits of portfolio diversification, there are a number of studies that document the importance of investor proximity in the financial performance of investments (Coval and Moskowitz, 1999, 2001; Levy and Sarnat, 1970). This implies that investors face a trade-off between the benefits of portfolio diversification and the financial performance of an investment.

Location is vital in real estate investments and local market information is likely to be quite valuable. Moreover, since the private real estate market is relatively opaque and illiquid, it is likely that access to local market information is salient in the performance of investors' portfolios. 
Being far away from assets can impede access to local market information. This would imply that the physical distance of the owner to her asset may affect the rent level and subsequently the market value of the assets. To overcome these difficulties an investor could employ a real estate advisor that possesses the local market knowledge and expertise to successfully invest in real estate.

In the second chapter, I analyze the relationship between investors' distance to their assets and the performance of these assets, studying the extent to which property managers can influence this relationship. Hedonic rent models are employed to control for other known rent determinants. It turns out that proximity matters: holding everything else constant, investors located closely to their investments in office buildings are able to extract significantly higher effective rents from these assets, especially if these buildings are of low quality. This effect is due to significant differences in occupancy levels. Interestingly, property managers can affect this relationship, mitigating the adverse effects of investor distance on office rents. Especially if the owner does not reside in the same state as the building, external property management is of importance, most prominently so for Class B office buildings.

Transaction intermediaries are ubiquitous in the real estate industry. Real estate investors retain advisors to buy, lease, and sell their assets. In chapter three, I study the economic implications of using these service providers, specifically investigating whether there is a scale advantage for intermediaries. I analyze datasets of U.S. commercial office rents and transaction prices, using hedonic models to investigate the effect of real estate advisor size on the financial performance of office buildings. The results show that buildings retaining the property management and leasing services of the largest real estate advisors in the market, command a 1.9 to 2.4 percent rent premium relative to buildings serviced by smaller advisors, after controlling for a broad set of building and location quality characteristics. However, the largest service providers underperform in terms of the pricing of sales transactions: we find a price discount of 1.9 percent for the largest listing brokers, and a price premium of 1.3 percent for the largest buying brokers. The reason that real estate owners still prefer large brokerage firms may be that these execute transactions faster: the buildings they advise on sell nine days faster than those buildings sold through their smaller competitors.

\subsection{The Environmental Implications of the Built Environment}

Carbon dioxide is by far the largest greenhouse gas - 65 percent of global greenhouse gas emissions in 2010 stem from carbon (IPCC, 2014). For a developed country such as the U.S., carbon emissions as a share of total greenhouse gas emissions are much higher, 81 percent in 2014. Moreover, 93.6 percent of carbon emissions in the U.S. stem from the combustion of fossil fuels. Real estate is responsible for some 40 percent of the U.S. carbon emissions in 2014, an increase of almost 20 percent relative to 1990 levels (EPA, 2016).

Until the start of the industrial revolution, the level of carbon dioxide in the atmosphere varied between 180 and 300 parts per million within 100,000-year cycles. Figure 1.2 displays the carbon concentration in the atmosphere over the last millennium. Based on trapped air in ice cores, scientists are able to measure historic carbon and temperature levels over the last 
Figure 1.2: Carbon Concentration in the Atmosphere (1000-2004)

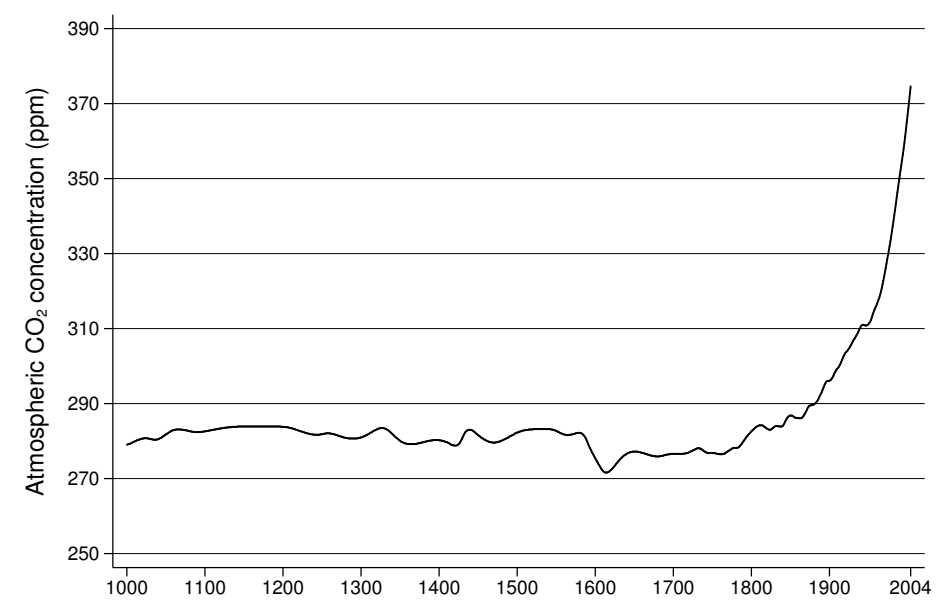

Source: WDC for Paleoclimatology, Boulder and NOAA Paleoclimatology Program, 2010

400,000 years. We are currently in a 10,000-year interglacial period with moderate temperatures, which explains the fact that we do not observe the low levels of carbon observed previously. As displayed in Figure 1.2, carbon dioxide levels in the atmosphere were fairly constant until about 1800 and have increased rapidly since. This corresponds with the start of the industrial revolution and the increased consumption of fossil fuels. Importantly and alarmingly, Figure 1.2 shows no signs of diminishing growth in atmospheric carbon levels.

Historically, the world's energy demands were met through the use of biofuels such as wood, charcoal and dung. The benefit of fossil fuel is its compressed nature, which allows larger quantities of energy to be stored in the same amount of fuel. However, this does not only hold for the energy stored in fossil fuel but also for the embedded carbon. Importantly, the carbon embedded in biofuels is part of the active carbon cycle. Releasing the embedded carbon in biofuels through combustion or natural decay does not impact the long-term carbon balance. This is a crucial difference when comparing the carbon implications of biofuels to those of fossil fuels. The carbon embedded in fossil fuels has slowly been removed from the active carbon cycle over millions of years. Burning fossil fuels forces the stored and condensed carbon back into the active carbon cycle in a very short time-span, which leads to an increase of the carbon concentration in the atmosphere.

The industrial revolution and its most prominent invention, the steam engine, relied heavily on the use of coal to supply the necessary energy. The use of coal during the industrial revolution was motivated by the ease of extraction and the shortage of firewood and charcoal. The petroleum industry became more important after the introduction of the internal combustion engine in the early twentieth century. Figure 1.3 presents the production of global energy from 1800 to 2008, which shows the gradual transition from biofuels to coal, crude oil and natural gas. The graph shows that as a society, we are still heavily dependent on fossil fuels to meet our energy needs. For example, the majority of the energy consumed in the U.S. in 2014 is produced by fossil fuels - only 18 percent of the energy production comes from clean energy sources, such as solar, hydro, wind, nuclear and biomass (EPA, 2016). In addition, from all three fossil 


\section{Figure 1.3: Energy Production by Fuel Type (1800-2008)}

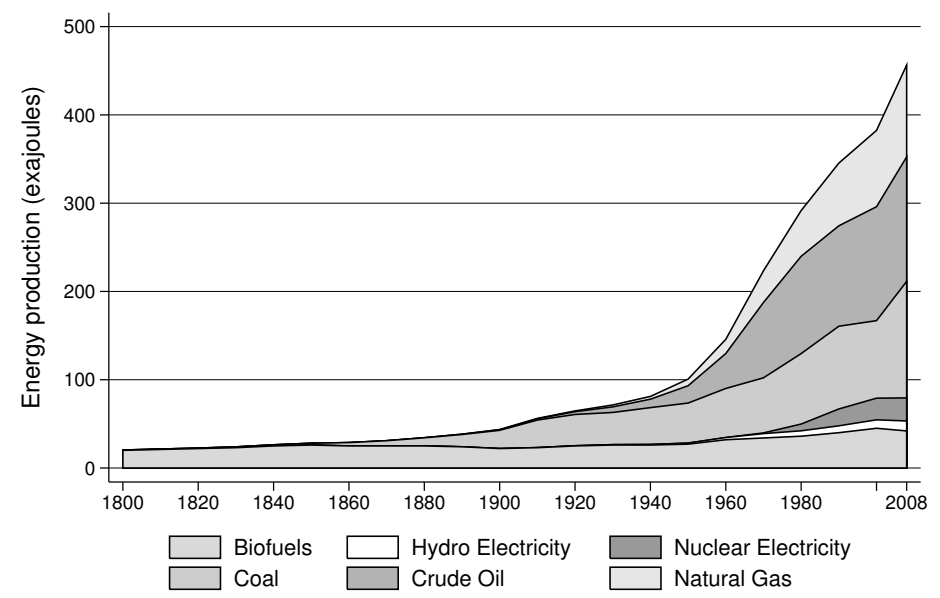

Source: Vaclav Smil, 2010

fuel types, coal emits the most carbon dioxide relative to crude oil and natural gas.

In the coming decades, global energy consumption will increase. Driven by economic development and population growth, the EIA predicts that 85 percent of the forecasted increase in world energy consumption stems from non-OECD countries. In 2010, a little over fifty percent of all energy was consumed by non-OECD nations, and this share is predicted to increase to 65 percent in 2040 (EIA, 2013). These forecasts indicate a continued pressure on the environment as developing countries move towards similar energy consumption patterns as observed in developed nations.

In order to be able to decrease our future energy consumption it is important to understand where most of the energy is consumed. Figure 1.4 displays the share of U.S. energy consumption by end-use sector over time. The transition from an industrial economy to a more serviceoriented society explains the decreasing trend observed for the share of energy consumed in the industrial sector, while the share of energy consumed by the built environment is increasing over time. In 2014, buildings consumed 40 percent of all energy, as compared to less than 30 percent in 1950.

Policy makers and regulators have responded to this challenge in different ways. Building codes have increasingly incorporated stricter requirements regarding the energy efficiency of newly constructed buildings. Specific building codes governing the insulation quality of new construction were first implemented in countries with colder climates, such as the Scandinavian countries, at the end of the 1950s and the early 1960s (Laustsen, 2008). The Netherlands, for example, has increased the minimum requirement regarding the thermal efficiency of newly constructed homes with each revision of the building code since 1965 (Aydin et al., 2015). Many other countries incorporated energy efficiency requirements in their building codes after the oil crisis in 1974.

Another type of regulatory response is the adoption of environmental building certification programs, which inform building owners, investors and prospective tenants about the energy performance of their asset. Such environmental building certificates take different shapes 
Figure 1.4: Share of U.S. Energy Consumption by End-Use Sector (1949-2014)

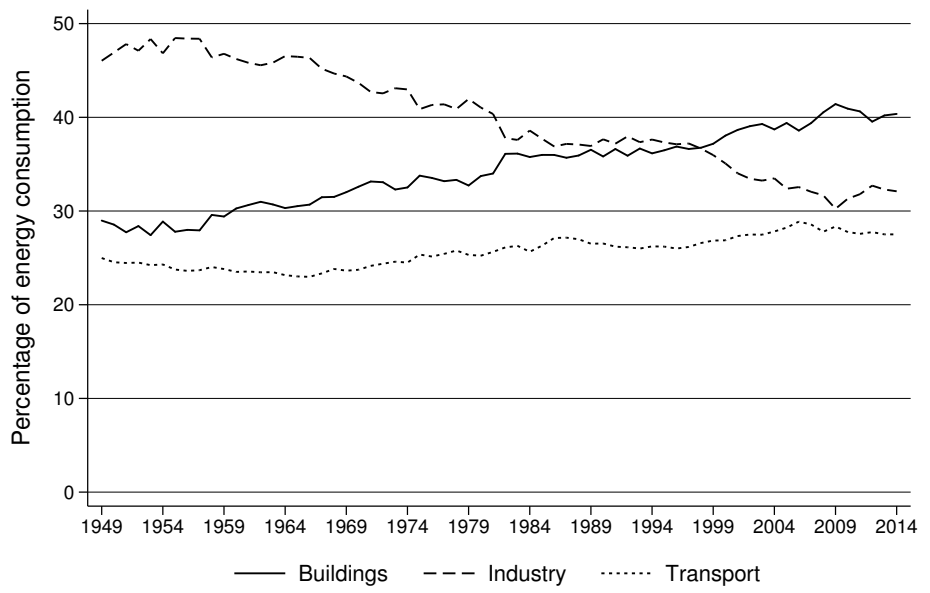

Source: Energy Information Agency, 2016

and forms across countries. For example, the emphasis on either energy efficiency or broader environmental and sustainability aspects of buildings differs across certification and labeling programs. Moreover, countries have approached the introduction of these building certification and labeling programs differently as well. For example, whereas the U.S. has taken a market driven approach through voluntary certification and labeling, and is now moving towards mandatory disclosure in some jurisdictions, the European Union implemented a mandatory building certification program from the start.

There are a number of studies that investigate the impact of energy efficiency and environmental performance on the financial performance of commercial real estate. These studies generally find positive rent and transaction price premiums for energy efficient and environmentally certified buildings, as well as higher and more stable occupancy rates. However, this literature is still relatively young, and many questions remain to be explored. ${ }^{1}$

In the fourth chapter, I map the adoption and analyze the financial outcomes of environmentally certified commercial real estate in the U.S. over time. At the end of 2014 nearly 40 percent of space in the 30 largest U.S. commercial real estate markets holds some kind of environmental certification as compared to less than 6 percent in 2005. Tracking the rental growth of some 26,000 office buildings, I measure the performance of environmentally certified real estate over time. Certified office buildings exhibit stronger rental growth over the period 2004-2013, as compared to a set of non-certified buildings. These effects are mostly indirect: higher and more stable occupancy rates explain the discrepancy in effective rent growth over the time period when comparing certified with non-certified office buildings. Furthermore, the relationship between rental growth and the environmental performance of assets is dynamic. Last, the performance attribution analysis indicates that local climate conditions, local energy prices and certification levels and scores lead to significant heterogeneity in market pricing. On aggregate, these findings provide some evidence on the efficiency of the market in pricing environmental

\footnotetext{
${ }^{1}$ See for example: Bonde and Song (2014); Chegut et al. (2014); Eichholtz et al. (2010, 2013); Fuerst and McAllister (2011); Kok and Jennen (2012); Zheng et al. (2012).
} 
characteristics of commercial real estate.

Whereas there is growing academic evidence for the financial performance of energy efficient and environmentally certified real estate, very little is known about the implications with respect to the cost of capital to finance these assets. Rent and transaction price premiums are one incentive to invest in energy efficient and environmentally certified real estate, a decrease in the cost of capital could be another important impetus to improve the environmental performance of buildings. This issue has not been investigated for commercial real estate.

Chapter five of this dissertation analyzes the cost of capital for environmentally certified assets. Using a sample of U.S. REITs, I investigate the spreads on commercial mortgages collateralized by real assets, some of which are environmentally certified. I also study spreads on corporate debt, both at issuance and while trading in the secondary market. The results show that environmentally certified buildings command significantly lower spreads as compared to conventional, but otherwise comparable buildings. The spread difference varies between 35 and 36 basis points, depending on the specification. At the corporate level, I document that REITs with a higher fraction of environmentally certified buildings are able to issue bonds at lower spreads, after controlling for a broad set of REIT and bond characteristics. A difference-indifference analysis of bond spreads in the secondary market corroborates this finding. The results in this chapter provide some evidence that the financial market capitalizes the environmental performance of collateral into the pricing of financial products.

Chapters four and five focus on the financial implications of environmental certification in commercial real estate. However, housing represents the largest share of the built environment. In Europe, a large share of the residential real estate market consists of affordable housing. The affordable housing sector in the Netherlands is the largest in Europe in relative terms 31 percent of all housing stock. Importantly, some four hundred institutions own 2.4 million affordable housing units. Mobilizing these institutions as opposed to each individual household in the owner-occupied housing sector to improve the energy efficiency and environmental performance of their asset can lead to large gains.

In chapter six of this dissertation I investigate the economic value of energy efficiency in affordable housing in the Netherlands. ${ }^{2}$ Strong rental protection in many jurisdictions prevents affordable housing institutions from benefiting from their investment in the improved energy efficiency of dwellings. This impedes the path towards increased environmental performance in affordable housing. In the Netherlands, affordable housing institutions regularly sell from their housing stock, and if they can sell their energy efficient dwellings at a premium, this may stimulate investments in the environmental performance of homes. I analyze the value effects of energy efficiency in the affordable housing market, by using a sample of homes sold by Dutch affordable housing institutions over the period 2008-2013. Energy Performance Certificates are used to determine the value of energy efficiency in these transactions. In line with this thesis, I document that dwellings with high energy efficiency sell for 2.0 to 6.3 percent more compared to otherwise similar dwellings with low energy efficiency. However, these premiums only reflect the value of a label increase. The combined premiums for refurbishing a dwelling and improving the energy efficiency are over 20 percent.

\footnotetext{
${ }^{2}$ There is a nascent literature regarding the value of energy efficiency in housing markets in Europe, Asia, and the U.S., but not for affordable housing. See for example: Brounen and Kok (2011); Cerin et al. (2014); Deng et al. (2012); Kahn and Kok (2014); Yoshida and Sugiura (2013).
} 



\section{Chapter 2}

\section{The Economic Effects of Owner Distance and Local Property Management in U.S. Office Markets*}

\subsection{Introduction}

Home bias, local bias and investor proximity are different names for the same issue: investors like to invest their capital closer to their own location than investment theory predicts, especially if their risk appetite decreases or their risk perception increases (Coval and Moskowitz, 1999, 2001; Levy and Sarnat, 1970).

Investor proximity is well documented in the financial literature, but it has not been documented whether such a phenomenon is at play in the commercial real estate market. Since the private real estate market is opaque and illiquid, it is likely that local information is salient in the performance of investors' portfolios. This would imply that the physical distance of the owner to her assets may affect the rent level and subsequently the market value of the assets. By observing office rent levels, we are able to investigate the value of local market information in the direct real estate market and measure the added benefit of local ownership.

We also study whether the impact of owner distance is mitigated by the use of property managers, who may have the local market and tenant knowledge that far-away landlords have less access to. Location is vital in real estate, and local market information is likely to be very valuable. The cost of not having access to it can be high, through missed opportunities and low performance. Retaining property managers can be a means to overcome such a lack of information, especially when investors are diversified across regions and the intermediary is local.

On the contrary, the use of an external property manager impairs the direct relationship of the owner to her buildings and its tenants, thereby possibly reducing the flow of performancerelevant information to the owner. On top of that, the use of an external property manager may create an agency conflict. So the effect of external property management on building performance is not clear ex ante. As far as we know, ours is the first study to analyse the

${ }^{*}$ This chapter is co-authored with Piet Eichholtz (Maastricht University) and Erkan Yönder (Özyeğin University), and is published in the Journal of Economic Geography. 
economic utility of these ubiquitous service providers to the real estate industry.

We use a sample of 21,653 U.S. office buildings from 2011 to empirically investigate these questions. We define investor proximity or distance in two ways: distance in miles and administrative closeness on four different levels, the zip code area, the city, the core based statistical area (hereafter, CBSA) and the state. This enables us to assess the possible impact of investor proximity in different degrees. We employ propensity score weighted hedonic rent models to analyse the effect of local ownership and to control for other factors known to be determining office rents.

The results are consistent and robust. First, we observe that investors tend to reside close to their assets. The median owner distance is only 5 miles. We also see clear patterns in owner proximity. Proximity is related to building quality, lower quality is associated with stronger proximity. Furthermore, we find a lower degree of investor proximity in buildings when external property managers are involved, so either out-of-town building owners are more likely to hire external property managers, or the involvement of a local property manager reduces the need to be close to one's assets.

Second, we find a highly significant effect of investor proximity on the effective rent level, and observe a substantial rent discount when an owner is far away from her assets, especially for lower-quality buildings. The results indicate that far-away ownership comes at an effective rent discount that varies from zero to 4.8 percent for Class A office buildings and 9.2 percent to 22.1 percent for Class $\mathrm{C}$ buildings. The discount also depends on the degree of proximity of the owner to the building. When measuring distance in miles, we see rents falling as distance increases up until an average distance of 80 miles. The effective rent is the result of the average contract rent and the occupancy rate of a building, and our results show that owner proximity and distance affect the latter far more than the former, suggesting that local information advantages are relevant in finding tenants rather than in negotiating a higher rent.

Third, we study the importance of the presence of external property management for the effective rent level of commercial real estate. The results of the analysis show that external property management adds value: we find a premium that depends on the specification, and which is most significant for Class B office buildings. This implies that property managers can partly offset the adverse effects of owner distance on effective rents for these buildings. If the owner is far away and hires a property manager, we find that the negative impact of distance is reduced. Moreover, our results show that smaller property managers, who are more closely located to the assets they manage than larger ones, add more value. Therefore, external property managers seem to make a difference especially when they have a local information advantage relative to their clients.

Our findings are important for real estate portfolio construction, since they show that regional diversification can have an adverse effect on performance. That does not imply that office investors should now revert to unreserved local specialization. Diversification still has beneficial risk-reduction effects, but these come at the price of a lower rent. So the real estate owner faces a trade-off between risk reduction and the rent level, and the retention of external property managers and the selection of better-quality buildings help investors make this tradeoff.

In the next section we will first discuss the literature regarding investor proximity and performance. We will then present the data and the empirical method, and the subsequent 
section will present the results with respect to the base models and subsamples. The chapter ends with concluding remarks.

\subsection{Local Asset Ownership and Information Access}

Local market information is likely to be important in any asset market, and especially so in real estate. Throughout the ages, old hands in the market have taught their young colleagues that three things matter in real estate: location, location and location. That makes it all the more interesting that the role of investor proximity, which is likely to be salient for access to local market information, has hardly received any attention in the real estate literature.

Contrary to real estate, this topic has been investigated quite extensively in the stock market. The initial literature regarding home bias and the consequences of proximity concerned international investments, and showed convincingly that investors, both individual and professional, invest more in their own country and less internationally than investment theory would predict. That choice seems to be warranted by performance: national investors outperform international investors. $^{2}$

More recently, researchers have started to investigate whether this home bias also holds on a more local level, i.e., within the same country. Such local biases in investor portfolios are indeed observed. Coval and Moskowitz $(1999,2001)$ perform an analysis on investment managers' portfolio choices in the U.S. and find that mutual fund managers exhibit a strong preference for locally headquartered firms. This preference is reflected in improved performance: Coval and Moskowitz (2001) show that fund managers earn abnormal returns in nearby investment.

Ivkovic and Weisbenner (2005) investigate whether such a local bias also holds for individual investors and whether local investments outperform non-local investments. It turns out that they do, and the results are stronger when moving away from S\&P500 companies. The authors attribute this result to reduced informational asymmetries when investors and their assets are close. When comparing the portfolio performance of these individual investors to professional money managers the authors find that professional managers share the same ability in filtering out local information.

Bodnaruk (2009) investigates a similar research question using Swedish stock ownership data for a large sample of individual investors between 1995 and 2001. Bodnaruk employs the geographic distance to the closest establishment of the respective company as a measure for proximity. He finds strong evidence for local specialization, and confirms that investing locally pays off. The relationship between performance and proximity is strongest for riskier local companies. Interestingly, investors change their portfolio composition when they move, apparently to reduce the distance to their investments. These results provide evidence that individual investors possess an information advantage with respect to local stocks.

Seasholes and Zhu (2010) study individual investor data in the U.S. from 1991 to 1996 to provide further insight into the local bias puzzle. The authors create passive local indices at the state and zip code level and show that after controlling for the market excess return and the

\footnotetext{
${ }^{2}$ International studies such as Levy and Sarnat (1970), Solnik (1974), French and Poterba (1991), Kang and Stulz (1997), Huberman (2001), and Ahearne et al. (2004) are just a few examples of the extent to which this issue has been investigated in the finance literature
} 
passive local index, individuals do not generate abnormal returns, on average. Therefore, the authors conclude that individual investors do not seem to possess value-relevant information.

The degree to which access to information influences the supply and pricing of external funds has been investigated in the banking literature as well. Degryse and Ongena (2005) document spatial price discrimination in bank lending. The authors find that loan rates are lower when the client is located closer to the bank.

Mian (2006) investigates the impact of distance within a bank on lending behavior. He concludes that greater cultural and geographic distance between a foreign bank's headquarters and local branches decreases lending to informationally difficult yet sound firms. Agarwal and Hauswald (2010) conclude that it is harder to obtain soft information on clients with increasing distance, which leads to reduced access to credit and more expensive loans.

There is also an emerging literature regarding firm-level performance and the effects of distance. Bronnenberg et al. (2009) find persistent distance effects in the market shares of consumer packaged goods industries: market shares are higher in markets close to a firm's city of origin. Landier et al. (2009) show that corporations are less likely to divest divisions located in the same state as their headquarters, and they find a negative relationship between employee dismissals and the distance between divisions and headquarters. They put this down to a combination of social considerations and information, and show that firms' geographical concentration increases with the difficulty to transfer information over long distances.

Giroud (2013) shows that a decrease in air travel time between a corporation's headquarters and its production plants leads to more investment in these plants, and an increase in total factor productivity. Bernstein et al. (2015) focus on the effects of distance between venture capital firms and the companies they invest in, and also use reductions in air travel time to identify these effects. They show that reductions in travel time lead to increased innovation and a higher initial public offering likelihood, and they attribute this to increased monitoring by the venture capital firm.

Dahl and Sorenson (2012) investigate the locational preferences of Danish startups, and find evidence that their ventures perform better - in terms of longevity, cash flows and profits when they are located in regions where the entrepreneurs have lived longer. They attribute this to better access to local information and social capital. Kalnins and Lafontaine (2013) show that firm establishments located further away from headquarters have a lower survival rate. For the lodging industry specifically, they find that increased distance to headquarters is associated with lower revenue per hotel room. The authors put these findings down to monitoring and local information asymmetry problems.

With respect to real estate, Eichholtz et al. $(2011,2001)$ compare the performance of listed international property companies with portfolios of local property companies with the same country weights. They show that portfolios of locals significantly outperform the international investors. For directly held real estate assets, the only available paper studying this question is Ling et al. (2014), and it investigates the relationship between transaction prices of commercial real estate assets and seller and buyer proximity. The authors find that distant buyers tend to pay a premium relative to local buyers due to higher search cost and an informational disadvantage.

Our study makes three main contributions to this literature. First, we investigate whether local bias is present in direct real estate markets in the first place. Second, we study office rents and occupancy instead of transaction prices, so we look whether owner proximity affects the 
cash flow performance of office buildings. Third, we investigate the effect of external property managers on the performance-distance relationship. Real estate investors routinely employ external local property managers. This may be motivated by a desire to mitigate the possible adverse effects of distance to their assets. An important contribution of this chapter is to shed light on the impact of external service providers in this context.

In the next sections we will further explore the role of local ownership in commercial real estate markets and its relationship with performance, and we will investigate whether a possible disadvantage borne by owning commercial real estate far away can be overcome by means of intermediaries such as property managers.

\subsection{Data Description}

\subsubsection{Data and Source}

In order to investigate the relationship between proximity, rent levels and the impact of intermediaries, we retrieve U.S. office market data from CoStar (CoStar Realty Information, Inc., 2011). ${ }^{3}$ CoStar Property comprises the largest commercial real estate database, both in terms of market coverage and in terms of the information available on the asset level. That alone is a strong reason to focus our analysis on the U.S. Besides that, we investigate the role of proximity for long distances, thus we need the largest possible market in terms of land area.

CoStar provides average rent information for a sample of 33,713 office buildings for 2011. However, we cannot employ all these observations. To mitigate the possibility that unobserved quality characteristics determine the impact of proximity on office rent levels we only include observations for which the most extensive set of hedonic characteristics is available. Moreover, in order to determine the degree of proximity of the owner to her asset, we need detailed information with respect to the owner's location, and we also need information on external property management, which is not available for all observations. Last, we need to have at least two observations per zip code area, which leads to a final sample of 21,653 observations spread over 2,030 zip code areas, resulting in an average of 23.6 observations per zip code area.

The analysis includes 206 out of the 955 U.S. CBSAs. On average, we have 105 observations per CBSA, with a minimum of 2 and a maximum of 1,415. About 85 percent of the observations are within the 50 largest CBSAs. ${ }^{4}$ Figure 2.1 provides a map showing the location of the 206 CBSAs included in the study, and gives the weight in the final sample for each CBSA in terms of the number of buildings. Figure 2.1 displays that our observations are evenly distributed across the main office markets in the U.S., with a large representation of the coastal areas and the mid-west. The map does not offer surprises in terms of a possible mismatch between an office market's actual importance and its representation in our sample.

At a later stage in the analysis we differentiate between buildings with and without external

\footnotetext{
${ }^{3}$ CoStar Realty Information, Inc. is a data vendor that provides information on more than 4.5 million commercial real estate assets in the U.S. and the U.K.. CoStar Property is one of their product offerings that includes historic and current market information for multiple asset types, such as industrial, multi-family, office and retail buildings.

${ }^{4}$ When we limit the subsequent analysis only to these 50 largest CBSAs, the results do not markedly differ from those reported in the article for the full set of 206 CBSAs. Table A.1 in Appendix A displays the main results for the analysis of the sample of the 50 largest CBSAs.
} 


\section{Figure 2.1: Quintiles of Number of Observations by CBSA}

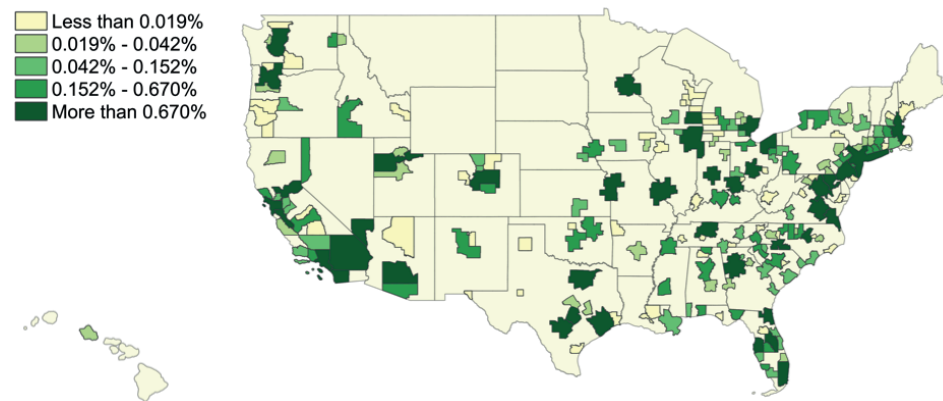

property management. Exploiting detailed information regarding the asset owner and property manager we are able to distinguish internal from external property management. Of the 21,653 buildings we observe, 7,465 are managed externally. A limitation of the chapter is that we have no information about the cost of property management, and we cannot control for the possibility that an observed premium for external property management is a reflection of the added cost of such a service provider. ${ }^{5}$ Moreover, we do not observe the quality of a property manager directly. However, we can identify the property management company, and we will use the estimated size of the company as a proxy for quality. We also know the location of the property manager, which we use as a proxy for local information access.

We use GIS techniques to determine the different degrees of owner distance to the asset, employing the geographical coordinates of the asset and the owner to calculate physical distance. Moreover, matching based on the geographical location of the asset and the owner enables us to define administrative closeness as well, on the zip code, city, CBSA and state level.

\subsubsection{Descriptive Statistics}

This section provides information regarding the statistical properties of the sample. Table 2.1 compares the average characteristics of the internally managed sample with the externally managed sample, which are provided in the first and second column, respectively. The differences in average building characteristics between the two subsamples are given in the third column.

The internally managed buildings in the sample command an average rent of some 18 dollars per square foot. When taking into account the average occupancy rate of 75 percent the effective rent, multiplying the occupancy rate with the average weighted rent, is about 14 dollars per square foot. With respect to size, the average building spans some 60,000 square feet divided over four stories. Most of the buildings have a Class B quality rating, whereas only 14 percent have a Class A rating and 31 percent of the buildings have a Class $C$ quality designation. ${ }^{6}$ The average building in our sample is about 37 years old. On average, 18 percent of the internally

\footnotetext{
${ }^{5}$ The property management fee depends on asset quality and size, and is in most cases directly passed through to the tenant as an operating expense. Depending on asset size and the specific market, the fees are generally between 1 and 2.5 percent of the total rental revenue plus reimbursement for on-site staff for larger office buildings.

${ }^{6}$ The definition of the building class designations as used by CoStar Realty Information, Inc. are summarized in Appendix B.
} 
managed buildings have been renovated and 20 percent of them have on-site amenities. ${ }^{7}$ Access to public transportation within a quarter mile is available for 13 percent of these buildings.

When we compare this with the externally managed buildings in our sample some interesting differences appear. On average, the buildings serviced by an external property manager command a substantially higher contract rent compared with the control buildings. Office buildings managed by an external property manager also have a higher and more stable occupancy rate, so the effective rent is significantly higher as well at almost 17 dollars per square foot.

However, we cannot conclude that these differences are due to the presence of a property manager, since the two sets of buildings also differ on a number of quality variables of which we know that they affect the rent per square foot. For example, with respect to building size, externally managed buildings are more than twice as large (133,000 sq. $\mathrm{ft}$.) and almost twice as tall (7 stories) compared with buildings that do not enjoy their services. Concerning building quality, Table 2.1 shows that buildings with a property manager are of higher quality when compared with non-managed buildings, and the difference is largest in the highest and lowest quality segments: 32 percent of the externally managed buildings have a Class A rating compared with only 14 percent of the non-managed buildings. Only 15 percent of the externally managed buildings are rated as Class $C$ while 31 percent of the non-managed buildings hold this rating. Buildings that have an external property manager tend to be somewhat newer as well, with an average age of about 35 years compared with an average age of about 37 years for non-managed buildings. Externally managed buildings are also more likely to have been renovated, and a larger fraction of the buildings with an external property manager have on-site amenities and access to public transportation.

Column (3) of Table 2.1 documents significant differences between the non-managed and managed sample and to account for that, we employ propensity score weighting. The weights are determined by estimating the propensity for each non-managed building to be managed based on a number of observable characteristics. The average building characteristics for the propensity score weighted non-managed sample are summarized in Column (4) of Table 2.1. Applying these propensity score weights reduces the difference between the managed and non-managed sample for almost every variable. Nevertheless, as the significant differences in the last column of Table 2.1 demonstrate, propensity score weighting is not able to completely neutralize the differences between the two samples. ${ }^{8}$

\footnotetext{
${ }^{7}$ One or more of the following amenities are available on-site: banking, convenience store, dry cleaner, exercise facilities, food court, food service, mail room, restaurant, retail shops, vending areas, fitness centre.

${ }^{8}$ The estimation procedure for the propensity score weights that we apply in the analyses and the robustness of our results with respect to the propensity score specification are discussed elaborately in Appendix C.
} 
Table 2.1: Building Characteristics

\begin{tabular}{|c|c|c|c|c|c|}
\hline & $\begin{array}{l}\text { Non-Managed } \\
\text { Sample } \\
\text { (1) }\end{array}$ & $\begin{array}{l}\text { Managed } \\
\text { Sample } \\
\text { (2) }\end{array}$ & $\begin{array}{c}\text { Difference } \\
\text { (1)-(2) } \\
\text { (3) }\end{array}$ & $\begin{array}{c}\text { Propensity } \\
\text { Score Weighted } \\
\text { Sample } \\
(4)\end{array}$ & $\begin{array}{c}\text { Difference } \\
(4)-(2) \\
(5)\end{array}$ \\
\hline Rent (\$ per sq. ft.) & $\begin{array}{c}18.10 \\
{[11.81]}\end{array}$ & $\begin{array}{c}20.88 \\
{[11.13]}\end{array}$ & $-2.79^{* * *}$ & $\begin{array}{c}19.48 \\
{[13.54]}\end{array}$ & $-1.40^{* * *}$ \\
\hline Effective Rent (\$ per sq. ft.) & $\begin{array}{c}13.91 \\
{[11.43]}\end{array}$ & $\begin{array}{c}16.72 \\
{[10.65]}\end{array}$ & $-2.81^{* * *}$ & $\begin{array}{c}15.41 \\
{[13.18]}\end{array}$ & $-1.31^{* * *}$ \\
\hline Occupancy (percent) & $\begin{array}{c}75.07 \\
{[23.12]}\end{array}$ & $\begin{array}{c}78.48 \\
{[19.27]}\end{array}$ & $-3.41^{* * *}$ & $\begin{array}{c}77.24 \\
{[21.75]}\end{array}$ & $-1.23^{* * *}$ \\
\hline Size (thousand sq. ft.) & $\begin{array}{r}59.85 \\
{[111.23]}\end{array}$ & $\begin{array}{c}132.77 \\
{[197.97]}\end{array}$ & $-72.92^{* * *}$ & $\begin{array}{c}102.26 \\
{[158.39]}\end{array}$ & $-30.51^{* * *}$ \\
\hline \multicolumn{6}{|l|}{ Building Class (percent) } \\
\hline Class A & 13.53 & 31.64 & $-18.11^{* * *}$ & 23.32 & $-8.32^{* * *}$ \\
\hline Class B & 55.19 & 53.82 & $1.37^{*}$ & 54.50 & 0.67 \\
\hline Class C & 31.27 & 14.53 & $16.74^{* * *}$ & 22.18 & $7.65^{* * *}$ \\
\hline Age (years) & $\begin{array}{c}37.46 \\
{[29.63]}\end{array}$ & $\begin{array}{c}35.36 \\
{[26.16]}\end{array}$ & $2.09^{* * *}$ & $\begin{array}{c}37.46 \\
{[29.28]}\end{array}$ & $2.09^{* * *}$ \\
\hline \multicolumn{6}{|l|}{ Age (percent) } \\
\hline$\leq 10$ years & 13.41 & 8.06 & $5.35^{* * *}$ & 12.00 & $3.94^{* * *}$ \\
\hline $11-20$ years & 10.97 & 11.17 & -0.21 & 11.22 & 0.05 \\
\hline $21-30$ years & 29.91 & 40.54 & $-10.63^{* * *}$ & 31.98 & $-8.56^{* * *}$ \\
\hline $31-40$ years & 17.33 & 18.96 & $-1.62^{* * *}$ & 17.07 & $-1.89^{* * *}$ \\
\hline $41-50$ years & 8.13 & 6.50 & $1.63^{* * *}$ & 8.06 & $1.56^{* * *}$ \\
\hline$>50$ years & 20.26 & 14.78 & $5.48^{* * *}$ & 19.52 & $4.74^{* * *}$ \\
\hline Stories (number) & $\begin{array}{c}3.93 \\
{[5.34]}\end{array}$ & $\begin{array}{c}7.02 \\
{[8.72]}\end{array}$ & $-3.10^{* * *}$ & $\begin{array}{c}5.72 \\
{[7.35]}\end{array}$ & $-1.30^{* * *}$ \\
\hline \multicolumn{6}{|l|}{ Stories (percent) } \\
\hline Low $(\leq 10)$ & 92.70 & 80.56 & $12.14^{* * *}$ & 85.72 & $5.16^{* * *}$ \\
\hline Medium (11-20) & 4.94 & 12.40 & $-7.46^{* * *}$ & 9.04 & $-3.36^{* * *}$ \\
\hline $\operatorname{High}(>20)$ & 2.36 & 7.03 & $-4.67^{* * *}$ & 5.23 & $-1.80^{* * *}$ \\
\hline Renovated (percent) & 17.59 & 26.03 & $-8.44^{* * *}$ & 23.02 & $-3.01^{* * *}$ \\
\hline On-site Amenities (percent) & 19.80 & 39.00 & $-19.20^{* * *}$ & 30.77 & $-8.22^{* * *}$ \\
\hline Public Transport (percent) & 12.61 & 20.92 & $-8.32^{* * *}$ & 17.17 & $-3.76^{* * *}$ \\
\hline Observations & 14,188 & 7,465 & & 14,188 & \\
\hline
\end{tabular}

Notes: Standard deviations in brackets. Significant differences on the $0.10,0.05$ and 0.01 level are denoted by *** and ${ }^{* * *}$ respectively.

\subsubsection{Investor Proximity in the U.S. Office Markets}

The CoStar data allow us to take a first look at the extent to which office ownership is local, and whether that differs across segments of the office market. We define local ownership using administrative boundaries and with distance measured in miles. Taking the administrative angle, we define an owner as local when she is located in the same zip code area as her building, and then look incrementally at the effect of increased distance for owners located in that city, that CBSA, that state or in other states. We use a real estate owner's headquarters as the location for that owner. 
Table 2.2 sheds some light on investor distances. The first row of Panels A and B of the table provide local ownership and owner distance information for the sample as a whole. We do not have data on the portfolio composition of these asset owners, so we cannot directly observe local bias in that perspective. Nonetheless, Table 2.2 does provide some intriguing indirect information regarding this issue as well. For example, if we define local as being in the same state, 76 percent of the offices in our sample are owned by local investors. The median owner distance for the sample as a whole is only 5.4 miles, but the average is 237 miles. ${ }^{9}$ This big difference between the mean and the median distance is caused by a limited number of nation-wide owners that operate out of one central location.

The bottom three rows of Panel A of the table differentiate across the three quality categories A, B and C, depicting the importance of local versus non-local ownership for each quality category. It turns out that no matter how we define local, the local investors tend to invest in lower-quality office buildings and vice versa. For Class $C$ buildings, more than 90 percent of the owners reside in the same state. That number is much lower for better quality assets, but even if we look at the A-labeled office buildings (for which non-local ownership is most common) we observe that more than 50 percent of the owners are based in the same state. When we look at owner distance measured in miles, Class A buildings stand out. For B and C rated buildings, the median distance is just a few miles, but for Class A buildings, it is more than 65 miles. So far-away owners have a clear preference for the best buildings.

It can be argued that Class $C$ buildings are of a more speculative kind when compared with Class $\mathrm{A}$ and $\mathrm{B}$ buildings, and the tendency to invest in higher quality buildings when being further away can be explained by a decreasing risk appetite or increasing risk perception. On the other hand, this finding might be explained by easier access to salient local information regarding such issues as the preferences and needs of existing and potential tenants and their willingness to pay for office space. Another issue that possibly plays a role here is that occupiers of Class A offices are often large nationwide organizations such as banks, consultancy companies and accounting firms, so local tenant information may matter less for these buildings.

Panel B of Table 2.2 compares the four degrees of local ownership and the distance measured in miles across buildings with and without an external property manager. The bottom two rows of Panel B clearly show that distant ownership is more likely when a building is externally managed and this holds for all four definitions of local ownership. Moreover, owners rarely invest outside of their home state without retaining a property manager. Less than 16 percent of the buildings without a property manager have an out-of-state owner. If an external property manager is present, this increases to 40 percent. The difference in distant ownership between the externally managed buildings and the other buildings in the sample is statistically significant for each of the four distance definitions.

These results provide an initial indication of a pattern in investor proximity in commercial real estate investments. They show a clear link between asset quality and investor proximity, and they also show that out-of-town investors are most likely to retain external property managers.

\footnotetext{
${ }^{9}$ Appendix D presents detailed distribution figures of owner distance across building classes and management types.
} 
Table 2.2: Non-Local Ownership and Distance

\begin{tabular}{|c|c|c|c|c|c|c|}
\hline & \multicolumn{4}{|c|}{ Local Ownership } & \multirow{2}{*}{$\begin{array}{l}\text { Average } \\
\text { Distance } \\
\text { (miles) }\end{array}$} & \multirow{2}{*}{$\begin{array}{l}\text { Median } \\
\text { Distance } \\
\text { (miles) }\end{array}$} \\
\hline & $\begin{array}{c}\text { Out of the Zip } \\
\text { code area }\end{array}$ & Out of City & $\begin{array}{l}\text { Out of the } \\
\text { CBSA }\end{array}$ & Out of State & & \\
\hline \multicolumn{7}{|c|}{ Panel A: Building Class } \\
\hline Total & 15.73 & 22.98 & 6.32 & 24.23 & $\begin{array}{c}237.2 \\
{[537.8]}\end{array}$ & 5.40 \\
\hline Class A & 9.08 & 17.70 & 6.10 & 49.79 & $\begin{array}{c}508.5 \\
{[745.8]}\end{array}$ & 65.60 \\
\hline Class B & 16.39 & 23.70 & 6.90 & 21.89 & $\begin{array}{c}209.0 \\
{[490.8]}\end{array}$ & 5.17 \\
\hline Class C & 19.49 & 25.52 & 5.25 & 9.25 & $\begin{array}{r}87.2 \\
{[323.8]}\end{array}$ & 2.40 \\
\hline \multicolumn{7}{|c|}{ Panel B: External Property Management } \\
\hline Total & 15.73 & 22.98 & 6.32 & 24.23 & $\begin{array}{r}237.20 \\
{[537.8]}\end{array}$ & 5.40 \\
\hline $\begin{array}{l}\text { Managed } \\
\text { Buildings }\end{array}$ & 12.67 & 19.41 & 6.93 & 40.07 & $\begin{array}{r}425.70 \\
{[685.1]}\end{array}$ & 16.30 \\
\hline $\begin{array}{l}\text { Non-Managed } \\
\text { Buildings }\end{array}$ & 17.35 & 24.85 & 6.01 & 15.90 & $\begin{array}{c}138.0 \\
{[407.4]}\end{array}$ & 3.50 \\
\hline
\end{tabular}

Notes: Standard deviations in brackets. Local ownership for the total sample, by building class and by property management categories is displayed in percentages.

\subsection{Empirical Framework}

To investigate how proximity relates to the rent level, we employ the standard hedonic valuation framework for real estate (Rosen, 1974). The sample of buildings is used to estimate a semi-log equation relating the average weighted rent, occupancy rate and effective rent to the characteristics and location of each building.

$$
\log R_{i}=\alpha+\sum_{j} \beta_{i} X_{i j}+\delta L_{i}+\epsilon_{i}
$$

In our base model in Equation (2.1), the dependent variable is the logarithm of $R$, which is either the effective rent per square foot, the average weighted rent per square foot or the occupancy rate of building $i . X$ is a vector of hedonic characteristics $j$ (size, age, number of stories, etc.) and a location dummy for building $i$ (based on the five-digit zip code). $L$ is the main variable of interest in our model. It is an indicator variable taking the value of one when building $i$ is owned by an out-of-town investor and zero otherwise, where out-of-town ownership is defined as the owner residing in a different zip code area, city, CBSA or state relative to the building. $\alpha$ is a constant, $\beta$ and $\delta$ are coefficients and $\epsilon$ is an error term. $\delta$ is thus the average effect associated with out-of-town ownership, in percent, as compared to otherwise similar buildings owned by local owners.

In a second set of estimates, we include additional terms in Equation (2.1), measuring the physical distance (in miles) between the asset and the owner to further disentangle the effect of out-of-town ownership. 
Interaction terms to measure the impact of the use of external property managers are included at a later stage as well. To account for quality differences between the samples of externally and internally managed buildings we employ propensity score weighting. The approach applied here is similar to the one used by Eichholtz et al. (2010). We use propensity score weighting to reduce the selection bias between the managed sample and the non-managed sample by weighting on the hedonic characteristics of the individual buildings. Using a logit model, differences between the "treated" buildings that have an external property manager and the "non-treated" buildings are moderated by estimating the propensity of having a property manager for all buildings in the sample. Subsequently these propensity scores are used in a weighted least squares regression of Equation (2.1). ${ }^{10}$

\subsection{Results}

\subsubsection{Proximity Premium and Distance Discount}

We test the impact of proximity and distance on the financial performance of office buildings in two ways: by defining distance based on four administrative levels and by the physical distance between the owner and the building. We assess administrative distance incrementally, and use local ownership (in the same zip code area) as the excluded category. We first study the effect of proximity and distance on the effective rent, which is the total gross cash flow received by a landlord. To get a more in-depth picture of the nature of the effects, we look separately at the average contract rent and the occupancy rate, the two building blocks of the effective rent. The analyses presented in this section control for all available building characteristics and include location fixed effects on the zip code level.

Columns (1) and (2) of Table 2.3 display the results for effective rent, first regarding administrative distance, and then distance in miles. Column (1) shows a consistent relationship between owner distance and effective rent: a distant owner receives a rental discount relative to a local one, and the size of that discount depends on the definition of local ownership. ${ }^{11}$ Landlords located in another zip code area than their building but within the same city receive a 6.8 percent rental discount relative to those residing in the same zip code area. The discount for those outside the city but within the same CBSA is not much different: 6.4 percent. When we go further, it drops to 10.1 percent for owners residing outside of their building's CBSA, and 9.2 percent for owners outside of their building's state. The discount is statistically significant in all cases. So investing very locally seems to be most beneficial in terms of rent level, and once an owner is located further than a building's CBSA borders, additional distance seems not to matter.

In order to grasp the economic implications of the 6.4 to 10.1 percent rent discount for distant ownership, we use the average building size to estimate the average rental discount (or premium) in dollars. This leads to an annual effective rent difference in the range of USD $81,000-128,000$ per building. By applying a capitalization rate of 6 percent, we estimate the value of a locally owned building to be USD 1.3-2.1 million higher than an otherwise comparable

\footnotetext{
${ }^{10}$ Appendix $\mathrm{C}$ provides a detailed discussion of the propensity score weighting procedure that we employ and the robustness of the results with respect to the specification of the propensity scores.

${ }^{11}$ Of course, we can also interpret these results as a premium for local ownership.
} 
Figure 2.2: Effective Rent and Owner Distance

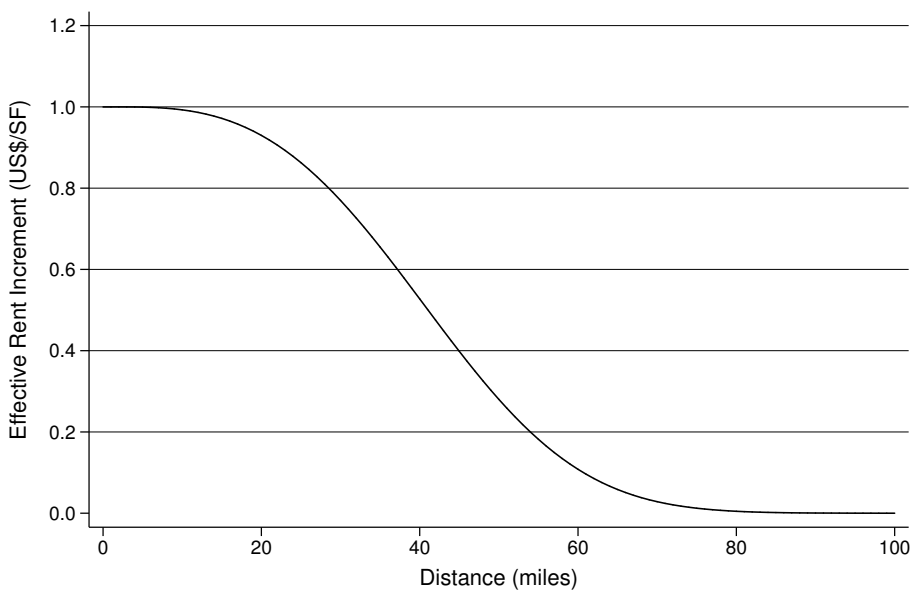

non-locally owned building. This is interesting, since Ling et al. (2014) find that far-away owners, on average, buy buildings at a premium. Combining our findings with theirs, we can conclude that distant owners have a double handicap in the real estate market.

Column (2) of Table 2.3 reports the results for straight-line physical distance (in miles) between the owner and her asset. The results show a highly significant non-linear relationship between owner distance and the effective rent level as displayed by the coefficients for owner distance, owner distance squared and owner distance to the third power. This relationship can be translated into the gradient for the effective rent increment presented in Figure 2.2. As displayed, the effective rent increment first decreases at an accelerating rate when owner distance increases and then flattens out when the distance of the owner to her asset is large. For owner distances above 80 miles, the effective rent increment is zero.

Thus, local owners get consistently higher rents, the question is why. The effective rent is the result of the contract rent and the occupancy rate. It is possible that local landlords get higher contract rents, perhaps through better negotiation power deriving from superior local market knowledge. However, that would also price them out of the market, since rational tenants would then prefer out-of-town landlords to get better deals at the negotiation table. It is more likely that local landlords outsmart their distant rivals by finding tenants in the first place, for example, that local landlords have consistently lower vacancies in their buildings. Columns (3) to (6) of Table 2.3 provide the empirical evidence.

Columns (3) and (4) show that distance does not matter much for the average contract rent received by a building's owner. Although we do find a statistically significant distance effect for landlords located outside of their building's city and CBSA, the effect is economically small. Measured in miles, we find no significant effect at all.

For the occupancy rate, however, the effects are in line with those we document for the effective rent, both in terms of size and in terms of statistical significance. So the information advantage that local owners have does not seem to be relevant in rental negotiations, but rather in the maintenance of active knowledge about the needs and space preferences of the current and potential tenants and of a network of possible new tenants. 
Table 2.3: Local Owernship and Rent Value

\begin{tabular}{|c|c|c|c|c|c|c|}
\hline & \multicolumn{2}{|c|}{ Effective rent } & \multicolumn{2}{|c|}{ Average rent } & \multicolumn{2}{|c|}{ Occupancy rate } \\
\hline & (1) & (2) & (3) & (4) & (5) & (6) \\
\hline Owner non-local zip code area & $-0.068^{* * *}$ & & -0.007 & & $-0.060 * * *$ & \\
\hline (1=yes) & {$[0.016]$} & & {$[0.007]$} & & {$[0.014]$} & \\
\hline Owner non-local city & $-0.064^{* * *}$ & & $-0.012^{*}$ & & $-0.051^{* * *}$ & \\
\hline (1=yes) & {$[0.013]$} & & {$[0.006]$} & & {$[0.011]$} & \\
\hline Owner non-local CBSA & $-0.101^{* * *}$ & & $-0.022^{* *}$ & & $-0.079^{* * *}$ & \\
\hline (1=yes) & {$[0.024]$} & & {$[0.010]$} & & {$[0.021]$} & \\
\hline $\begin{array}{l}\text { Owner non-local state } \\
(1=\text { yes })\end{array}$ & $\begin{array}{c}-0.092^{* * *} \\
{[0.013]}\end{array}$ & & $\begin{array}{r}-0.007 \\
{[0.007]}\end{array}$ & & $\begin{array}{c}-0.085^{* * *} \\
{[0.011]}\end{array}$ & \\
\hline Owner distance & & $\begin{array}{l}-0.117^{* * *} \\
{[0.037]}\end{array}$ & & $\begin{array}{c}-0.022 \\
{[0.019]}\end{array}$ & & $\begin{array}{c}-0.095^{* * *} \\
{[0.030]}\end{array}$ \\
\hline Owner distance ${ }^{2}$ & & $\begin{array}{l}0.070^{* *} \\
{[0.029]}\end{array}$ & & $\begin{array}{c}0.016 \\
{[0.016]}\end{array}$ & & $\begin{array}{l}0.054^{* *} \\
{[0.022]}\end{array}$ \\
\hline Owner distance ${ }^{3}$ & & $\begin{array}{c}-0.011^{* *} \\
{[0.005]}\end{array}$ & & $\begin{array}{r}-0.003 \\
{[0.003]}\end{array}$ & & $\begin{array}{c}-0.008^{* *} \\
{[0.004]}\end{array}$ \\
\hline $\begin{array}{l}\text { Log size } \\
\text { (thousand sq. ft.) }\end{array}$ & $\begin{array}{l}0.126^{* * *} \\
{[0.008]}\end{array}$ & $\begin{array}{l}0.123^{* * *} \\
{[0.008]}\end{array}$ & $\begin{array}{l}0.039^{* * *} \\
{[0.003]}\end{array}$ & $\begin{array}{l}0.040^{* * *} \\
{[0.003]}\end{array}$ & $\begin{array}{l}0.086^{* * *} \\
{[0.007]}\end{array}$ & $\begin{array}{l}0.083^{* * *} \\
{[0.007]}\end{array}$ \\
\hline Stories (1=yes) & & & & & & \\
\hline Medium (11-20) & $\begin{array}{c}-0.003 \\
{[0.018]}\end{array}$ & $\begin{array}{c}-0.002 \\
{[0.017]}\end{array}$ & $\begin{array}{c}0.006 \\
{[0.010]}\end{array}$ & $\begin{array}{c}0.006 \\
{[0.010]}\end{array}$ & $\begin{array}{r}-0.009 \\
{[0.015]}\end{array}$ & $\begin{array}{c}-0.008 \\
{[0.015]}\end{array}$ \\
\hline High $(\geq 20)$ & $\begin{array}{c}-0.010 \\
{[0.029]}\end{array}$ & $\begin{array}{r}-0.008 \\
{[0.029]}\end{array}$ & $\begin{array}{r}-0.016 \\
{[0.017]}\end{array}$ & $\begin{array}{r}-0.015 \\
{[0.017]}\end{array}$ & $\begin{array}{c}0.006 \\
{[0.022]}\end{array}$ & $\begin{array}{c}0.007 \\
{[0.022]}\end{array}$ \\
\hline Building class ( $1=y e s)$ & & & & & & \\
\hline Class A & $\begin{array}{l}0.195^{* * *} \\
{[0.024]}\end{array}$ & $\begin{array}{l}0.193^{* * *} \\
{[0.024]}\end{array}$ & $\begin{array}{l}0.212^{* * *} \\
{[0.010]}\end{array}$ & $\begin{array}{l}0.213^{* * *} \\
{[0.010]}\end{array}$ & $\begin{array}{c}-0.017 \\
{[0.020]}\end{array}$ & $\begin{array}{c}-0.019 \\
{[0.020]}\end{array}$ \\
\hline Class B & $\begin{array}{l}0.079^{* * *} \\
{[0.016]}\end{array}$ & $\begin{array}{l}0.078^{* * *} \\
{[0.016]}\end{array}$ & $\begin{array}{l}0.093^{* * *} \\
{[0.007]}\end{array}$ & $\begin{array}{l}0.093^{* * *} \\
{[0.007]}\end{array}$ & $\begin{array}{c}-0.014 \\
{[0.014]}\end{array}$ & $\begin{array}{c}-0.016 \\
{[0.014]}\end{array}$ \\
\hline Age (1=yes) & & & & & & \\
\hline$\leq 10$ years & $\begin{array}{l}0.114^{* * *} \\
{[0.027]}\end{array}$ & $\begin{array}{l}0.114^{* * *} \\
{[0.027]}\end{array}$ & $\begin{array}{l}0.158^{* * *} \\
{[0.013]}\end{array}$ & $\begin{array}{l}0.158^{* * *} \\
{[0.013]}\end{array}$ & $\begin{array}{r}-0.044^{*} \\
{[0.024]}\end{array}$ & $\begin{array}{r}-0.044^{*} \\
{[0.024]}\end{array}$ \\
\hline $11-20$ years & $\begin{array}{l}0.085^{* * *} \\
{[0.027]}\end{array}$ & $\begin{array}{l}0.083^{* * *} \\
{[0.027]}\end{array}$ & $\begin{array}{l}0.083^{* * *} \\
{[0.013]}\end{array}$ & $\begin{array}{l}0.083^{* * *} \\
{[0.013]}\end{array}$ & $\begin{array}{c}0.003 \\
{[0.023]}\end{array}$ & $\begin{array}{c}0.000 \\
{[0.023]}\end{array}$ \\
\hline 21-30 years & $\begin{array}{c}0.024 \\
{[0.023]}\end{array}$ & $\begin{array}{c}0.019 \\
{[0.023]}\end{array}$ & $\begin{array}{l}0.033^{* * *} \\
{[0.011]}\end{array}$ & $\begin{array}{l}0.032^{* * *} \\
{[0.011]}\end{array}$ & $\begin{array}{c}-0.009 \\
{[0.019]}\end{array}$ & $\begin{array}{r}-0.013 \\
{[0.019]}\end{array}$ \\
\hline $31-40$ years & $\begin{array}{c}0.001 \\
{[0.023]}\end{array}$ & $\begin{array}{r}-0.001 \\
{[0.023]}\end{array}$ & $\begin{array}{c}0.006 \\
{[0.012]}\end{array}$ & $\begin{array}{c}0.006 \\
{[0.012]}\end{array}$ & $\begin{array}{r}-0.005 \\
{[0.019]}\end{array}$ & $\begin{array}{r}-0.007 \\
{[0.019]}\end{array}$ \\
\hline $41-50$ years & $\begin{array}{c}0.001 \\
{[0.024]}\end{array}$ & $\begin{array}{r}-0.001 \\
{[0.024]}\end{array}$ & $\begin{array}{c}0.008 \\
{[0.011]}\end{array}$ & $\begin{array}{c}0.008 \\
{[0.011]}\end{array}$ & $\begin{array}{c}-0.007 \\
{[0.020]}\end{array}$ & $\begin{array}{r}-0.009 \\
{[0.020]}\end{array}$ \\
\hline Renovated (1=yes) & $\begin{array}{r}-0.018 \\
{[0.013]}\end{array}$ & $\begin{array}{c}-0.021 \\
{[0.013]}\end{array}$ & $\begin{array}{l}0.012^{*} \\
{[0.006]}\end{array}$ & $\begin{array}{c}0.011^{*} \\
{[0.006]}\end{array}$ & $\begin{array}{c}-0.030^{* * *} \\
{[0.011]}\end{array}$ & $\begin{array}{c}-0.032^{* * *} \\
{[0.011]}\end{array}$ \\
\hline On-site amenities (1=yes) & $\begin{array}{l}0.034^{* * *} \\
{[0.013]}\end{array}$ & $\begin{array}{l}0.033^{* *} \\
{[0.013]}\end{array}$ & $\begin{array}{l}0.028^{* * *} \\
{[0.006]}\end{array}$ & $\begin{array}{l}0.028^{* * *} \\
{[0.006]}\end{array}$ & $\begin{array}{c}0.006 \\
{[0.011]}\end{array}$ & $\begin{array}{c}0.006 \\
{[0.012]}\end{array}$ \\
\hline Public transport (1=yes) & $\begin{array}{c}0.021 \\
{[0.027]}\end{array}$ & $\begin{array}{c}0.021 \\
{[0.027]}\end{array}$ & $\begin{array}{c}0.028^{* *} \\
{[0.013]}\end{array}$ & $\begin{array}{c}0.028^{* *} \\
{[0.013]}\end{array}$ & $\begin{array}{r}-0.007 \\
{[0.024]}\end{array}$ & $\begin{array}{c}-0.007 \\
{[0.024]}\end{array}$ \\
\hline
\end{tabular}


Table 2.3 (continued from previous page)

\begin{tabular}{lcccccc}
\hline & \multicolumn{2}{c}{ Effective rent } & \multicolumn{2}{c}{ Average rent } & \multicolumn{2}{c}{ Occupancy rate } \\
& $(1)$ & $(2)$ & $(3)$ & $(4)$ & $(5)$ & $(6)$ \\
\hline Location fixed effects & yes & yes & yes & yes & yes & yes \\
Observations & 21,653 & 21,653 & 21,653 & 21,653 & 21,653 & 21,653 \\
$\mathrm{R}^{2}$ & 0.41 & 0.41 & 0.70 & 0.70 & 0.15 & 0.15 \\
Adj. $\mathrm{R}^{2}$ & 0.35 & 0.34 & 0.67 & 0.66 & 0.06 & 0.06 \\
\hline
\end{tabular}

Notes: Table 2.3 shows the results from a propensity score weighted regression model using the logarithm of effective rent per square foot, logarithm of average rent per square foot, or occupancy rate as dependent variable. Standard errors clustered at the zip code level in brackets. Significance at the $0.10,0.05$, and 0.01 level is indicated by ${ }^{*},{ }^{* *}$, and ${ }^{* * *}$, respectively.

In Table 2.2, we show that investment decisions and building quality are related: investors apparently are more willing to invest in distant buildings when they are of high (Class A) quality, while they tend to stay closer to home for lower quality buildings. That choice may be driven by the premiums and discounts related to owner proximity and distance.

In order to test this, we re-estimate Equation (2.1) for each of the three building quality classes separately. The estimation outcomes reported in Table 2.4 are based on the effective rent model of Table 2.3, including building characteristics and location fixed effects, but for brevity we only report the variables of interest. The results are clear: the lower the quality of a building is, the bigger is the penalty for being far away from it. For Class A buildings, we find a significant distance discount only for out-of-state owners, and it is 4.8 percent. For Class B buildings, the discount is significant for all definitions of administrative distance, and varies between 4.8 percent and 10 percent, and for Class $\mathrm{C}$ buildings, it is even higher, varying between 9.2 percent and 22.1 percent. ${ }^{12}$ Therefore, it seems that owners are justified to avoid low-quality buildings that are far away.

This finding is closely in line with Ivkovic and Weisbenner (2005) and Bodnaruk (2009), who also find that the adverse effects of distance to one's assets are especially significant for lower quality and more risky assets. It may be caused by increased information asymmetries resulting from investment in such assets.

\subsubsection{Owner Distance and Property Management}

In the previous section we establish that owner proximity has a significantly positive impact on the effective rent level of a building, or put in other words, that owner distance carries a rental discount. We also note that the rental difference between locally and non-locally owned buildings is largest for low-quality buildings. Given these findings, this section investigates whether an external property manager can mitigate the adverse effects associated with being far away from one's asset.

\footnotetext{
${ }^{12}$ In contrast to the results documented for administrative distance in Column (5) the coefficients for owner distance, owner distance squared and owner distance to the third power in Column (6) are not significant. This is caused by dependence between the polynomial terms. In an alternative specification we only include owner distance and owner distance squared to test the non-linear relationship between owner distance and the effective rent per square foot for Class $C$ buildings. This specification yields a significant coefficient for owner distance squared; the coefficient for owner distance is only borderline significant. However, for consistency reasons we report on all three measurements of distance in Column (6).
} 
Table 2.4: Local Ownership and Rent Value, by Building Class

\begin{tabular}{|c|c|c|c|c|c|c|}
\hline & \multicolumn{2}{|c|}{ Class A } & \multicolumn{2}{|c|}{ Class B } & \multicolumn{2}{|c|}{ Class C } \\
\hline & (1) & (2) & (3) & (4) & (5) & (6) \\
\hline Owner non-local zip code area & -0.031 & & $-0.067^{* * *}$ & & $-0.092^{* *}$ & \\
\hline (1=yes) & {$[0.031]$} & & {$[0.023]$} & & {$[0.041]$} & \\
\hline Owner non-local city & -0.033 & & $-0.048^{* * *}$ & & $-0.131^{* * *}$ & \\
\hline (1=yes) & {$[0.029]$} & & {$[0.018]$} & & {$[0.040]$} & \\
\hline Owner non-local CBSA & -0.043 & & $-0.088^{* *}$ & & $-0.221^{* * *}$ & \\
\hline (1=yes) & {$[0.046]$} & & {$[0.039]$} & & {$[0.064]$} & \\
\hline Owner non-local state & $-0.048^{* *}$ & & $-0.100^{* * *}$ & & $-0.116^{*}$ & \\
\hline (1=yes) & {$[0.024]$} & & {$[0.020]$} & & {$[0.069]$} & \\
\hline Owner distance & & -0.031 & & $-0.184^{* * *}$ & & -0.449 \\
\hline & & {$[0.056]$} & & {$[0.064]$} & & {$[0.295]$} \\
\hline Owner distance $^{2}$ & & 0.008 & & $0.140^{* *}$ & & 0.403 \\
\hline & & {$[0.036]$} & & {$[0.056]$} & & {$[0.305]$} \\
\hline Owner distance ${ }^{3}$ & & 0.001 & & $-0.029 * *$ & & -0.079 \\
\hline & & {$[0.005]$} & & {$[0.012]$} & & {$[0.074]$} \\
\hline Building characteristics & yes & yes & yes & yes & yes & yes \\
\hline Location fixed effects & yes & yes & yes & yes & yes & yes \\
\hline Observations & 4,282 & 4,282 & 11,849 & 11,849 & 5,522 & 5,522 \\
\hline $\mathrm{R}^{2}$ & 0.54 & 0.54 & 0.40 & 0.40 & 0.43 & 0.42 \\
\hline Adj. $R^{2}$ & 0.41 & 0.41 & 0.29 & 0.28 & 0.21 & 0.21 \\
\hline
\end{tabular}

Notes: Table 2.4 shows the results from a propensity score weighted regression model using the logarithm of effective rent per square foot as dependent variable. Standard errors clustered at the zip code level in brackets. Significance at the $0.10,0.05$, and 0.01 level is indicated by $* * *$, and ${ }^{* * *}$, respectively.

In the commercial real estate market external property managers are often hired to manage the day-to-day operations of an asset. A specialized property manager might positively influence the quality of a building and subsequently the cash flow of the building due to superior skills and expertise. Ling and Archer (2010) define a property manager as the company or individual responsible for the day-to-day operations of a building. As such, property management is perceived as a means to preserve or enhance the quality of a building, thereby increasing tenant satisfaction, which may in turn affect rent levels and occupancy.

We establish the economic benefit of an external property manager by adding a dummy to Equation (2.1), taking the value of one if an external property manager is active in a building, and zero otherwise. We also interact these variables with the out-of-town ownership variables. We focus the analysis on the effective rent per square foot, and subsequently also distinguish between average contract rent and occupancy rate.

Table 2.5 displays the regression results, again distinguishing four sets of boundaries defining local ownership, as well as straight-line distance between the owner and her building. The table consistently shows a negative effect of out-of-town ownership, of which the magnitude is in line with the results we previously reported in Table 2.3. More importantly, however, the table also makes clear that external property management has a significantly positive impact on the effective rent level in some cases, partly mitigating the negative distance effect. The effect of the external property manager alone is highest in the specifications without the interaction terms between the property manager dummy and the owner location dummies. In these cases, an 
external property manager is associated with a rental premium of 3.6 to 3.7 percent. When we do include these interaction terms, in Column (3), we find that property managers only add significant value for out-of-state owners. We find a premium of 5.4 percent associated with property management, considerably reducing the distance discount of 12.5 percent for these owners. Nevertheless, when we test the combined effect of non-local ownership and property management, it remains significantly negative in all cases.

Table 2.5: Property Management and Local Ownership

\begin{tabular}{|c|c|c|c|c|}
\hline & (1) & (2) & (3) & (4) \\
\hline \multirow{2}{*}{ Property manager (1=yes) } & $0.037^{* * *}$ & $0.036^{* * *}$ & 0.013 & $0.022^{*}$ \\
\hline & {$[0.011]$} & [0.011] & {$[0.016]$} & {$[0.012]$} \\
\hline \multirow[t]{2}{*}{ Owner non-local zip code area (1=yes) } & $-0.068^{* * *}$ & & $-0.075^{* * *}$ & \\
\hline & {$[0.016]$} & & {$[0.019]$} & \\
\hline \multirow[t]{2}{*}{ Owner non-local city (1=yes) } & $-0.064^{* * *}$ & & $-0.067^{* * *}$ & \\
\hline & {$[0.013]$} & & {$[0.017]$} & \\
\hline \multirow[t]{2}{*}{ Owner non-local CBSA (1=yes) } & $-0.104^{* * *}$ & & $-0.103^{* * *}$ & \\
\hline & {$[0.025]$} & & {$[0.035]$} & \\
\hline \multirow[t]{2}{*}{ Owner non-local state (1=yes) } & $-0.099 * * *$ & & $-0.125^{* * *}$ & \\
\hline & {$[0.014]$} & & {$[0.020]$} & \\
\hline Owner non-local zip code area * & & & 0.024 & \\
\hline Property manager (1=yes) & & & {$[0.031]$} & \\
\hline Owner non-local city * & & & 0.014 & \\
\hline Property manager (1=yes) & & & {$[0.024]$} & \\
\hline Owner non-local CBSA * & & & 0.007 & \\
\hline Property manager (1=yes) & & & {$[0.042]$} & \\
\hline Owner non-local state * & & & $0.054^{* *}$ & \\
\hline Property manager (1=yes) & & & {$[0.023]$} & \\
\hline \multirow[t]{2}{*}{ Owner distance } & & $-0.135^{* * *}$ & & $-0.254^{* * *}$ \\
\hline & & {$[0.039]$} & & {$[0.069]$} \\
\hline \multirow[t]{2}{*}{ Owner distance ${ }^{2}$} & & $0.079^{* * *}$ & & $0.165^{* * *}$ \\
\hline & & {$[0.030]$} & & {$[0.057]$} \\
\hline \multirow{2}{*}{ Owner distance ${ }^{3}$} & & $-0.012^{* *}$ & & $-0.024^{* *}$ \\
\hline & & {$[0.005]$} & & {$[0.011]$} \\
\hline Owner distance * & & & & $0.191^{* *}$ \\
\hline Property manager & & & & {$[0.075]$} \\
\hline Owner distance ${ }^{2 *}$ & & & & $-0.136^{* *}$ \\
\hline Property manager & & & & {$[0.062]$} \\
\hline Owner distance $\mathrm{e}^{3 *}$ & & & & 0.019 \\
\hline Property manager & & & & {$[0.012]$} \\
\hline Building characteristics & yes & yes & yes & yes \\
\hline Location fixed effects & yes & yes & yes & yes \\
\hline Observations & 21,653 & 21,653 & 21,653 & 21,653 \\
\hline $\mathrm{R}^{2}$ & 0.41 & 0.41 & 0.41 & 0.41 \\
\hline Adj. $R^{2}$ & 0.35 & 0.34 & 0.35 & 0.35 \\
\hline
\end{tabular}

Notes: Table 2.5 shows the results from a propensity score weighted regression model using the logarithm of effective rent per square foot as dependent variable. Standard errors clustered at the zip code level in brackets. Significance at the 0.10, 0.05 , and 0.01 level is indicated by ${ }^{* * *}$, and ${ }^{* * *}$, respectively. 
If we look at distance as the crow flies (Column (4)), again using distance, distance squared and distance to the third power, we find a similar owner distance effect as before. However, we also find that both the effect of an external property manager alone and the interaction of the property management dummy with these distance terms significantly and consistently mitigate that effect. So an external property manager is able to partly offset the negative effects associated with far-away ownership.

In further analyses not reported in the table, we separate the effective rent into the average contract rent and the occupancy rate to see where external property managers add value. We only find a significant effect of external property management in the latter, and not in the former. This suggests that property managers are important in finding and retaining tenants rather than in the rent negotiations with these tenants. ${ }^{13}$

\subsubsection{Building Quality and Property Management}

To further determine the factors that influence the observed impact of proximity we perform a set of subsample analyses based on the different quality categories of the buildings. Specifically, we use the same models as presented in Table 2.5 separately for each building quality class, A, B, and $C$.

Table 2.6 displays the results for the building class subsamples, with the odd columns reporting results for administrative distance and the even columns distance in miles. The key results of Table 2.6 are those concerning the effects of external property management, which are very interesting. It appears that external property management does not add much value for distant owners of Class A buildings. We find that the coefficients for the external property manager dummy and its interaction with distance tend to have positive signs, but these coefficients are never statistically significant, no matter how we delineate local and distant ownership. Interestingly, despite the apparent inability for external property management to add value in this building class, this is the building class in which the service is most common: about 55 percent of Class A office buildings have an external property manager. That makes it likely that these property managers add value in another way, not reflected in our data.

For Class $\mathrm{C}$ buildings also, the manager dummy and interaction coefficients are not statistically significant. The general lack of significance may be caused by the fact that both far-away ownership and external property management are quite rare in Class $C$ office buildings. The median distance between these buildings and their owners is only 2.4 miles, and less than 10 percent of Class $C$ assets are owned out-of-state. Additionally, only 20 percent of these buildings have an external property manager.

\footnotetext{
${ }^{13}$ Table E.1 in Appendix E displays the results using the average weighted rent per square foot and occupancy rate as dependent variables.
} 
Table 2.6: Property Management and Local Ownership, by Building Class

\begin{tabular}{|c|c|c|c|c|c|c|}
\hline & \multicolumn{2}{|c|}{ Class A } & \multicolumn{2}{|c|}{ Class B } & \multicolumn{2}{|c|}{ Class C } \\
\hline & (1) & (2) & (3) & (4) & (5) & (6) \\
\hline \multirow[t]{2}{*}{ Property manager (1=yes) } & -0.007 & 0.037 & $0.040^{*}$ & 0.024 & -0.009 & 0.015 \\
\hline & {$[0.032]$} & {$[0.023]$} & {$[0.022]$} & {$[0.017]$} & {$[0.049]$} & {$[0.032]$} \\
\hline Owner non-local zip code area & -0.034 & & $-0.062^{* *}$ & & $-0.117^{* *}$ & \\
\hline (1=yes) & {$[0.039]$} & & {$[0.028]$} & & {$[0.049]$} & \\
\hline Owner non-local city & -0.055 & & -0.037 & & $-0.147^{* * *}$ & \\
\hline (1=yes) & {$[0.041]$} & & {$[0.024]$} & & {$[0.049]$} & \\
\hline Owner non-local CBSA & -0.111 & & $-0.091^{*}$ & & $-0.203^{* * *}$ & \\
\hline (1=yes) & {$[0.082]$} & & {$[0.054]$} & & {$[0.074]$} & \\
\hline Owner non-local state & $-0.082^{* *}$ & & $-0.149^{* * *}$ & & $-0.162^{*}$ & \\
\hline (1=yes) & {$[0.039]$} & & {$[0.030]$} & & {$[0.088]$} & \\
\hline Owner non-local zip code area * & 0.010 & & -0.015 & & 0.108 & \\
\hline Property manager (1=yes) & {$[0.056]$} & & {$[0.048]$} & & {$[0.086]$} & \\
\hline Owner non-local city * & 0.055 & & -0.031 & & 0.061 & \\
\hline Property manager (1=yes) & {$[0.050]$} & & {$[0.035]$} & & {$[0.076]$} & \\
\hline Owner non-local CBSA * & 0.122 & & 0.003 & & -0.066 & \\
\hline Property manager (1=yes) & {$[0.090]$} & & {$[0.055]$} & & {$[0.128]$} & \\
\hline Owner non-local state * & 0.051 & & $0.072^{* *}$ & & 0.138 & \\
\hline Property manager (1=yes) & {$[0.042]$} & & {$[0.034]$} & & {$[0.111]$} & \\
\hline \multirow[t]{2}{*}{ Owner distance } & & -0.086 & & $-0.529^{* * *}$ & & $-0.990^{*}$ \\
\hline & & {$[0.099]$} & & {$[0.163]$} & & {$[0.513]$} \\
\hline \multirow[t]{2}{*}{ Owner distance $^{2}$} & & 0.044 & & $0.534^{* * *}$ & & $1.126^{*}$ \\
\hline & & {$[0.066]$} & & {$[0.196]$} & & {$[0.638]$} \\
\hline \multirow[t]{2}{*}{ Owner distance $^{3}$} & & -0.002 & & $-0.139^{* *}$ & & $-0.302^{*}$ \\
\hline & & {$[0.010]$} & & {$[0.057]$} & & {$[0.179]$} \\
\hline Owner distance * & & 0.040 & & $0.434^{* *}$ & & 0.801 \\
\hline Property manager & & {$[0.103]$} & & {$[0.171]$} & & {$[0.556]$} \\
\hline Owner distance ${ }^{2 *}$ & & -0.033 & & $-0.463^{* *}$ & & -0.925 \\
\hline Property manager & & {$[0.073]$} & & {$[0.199]$} & & {$[0.671]$} \\
\hline Owner distance ${ }^{3 *}$ & & 0.002 & & $0.123^{* *}$ & & 0.271 \\
\hline Property manager & & {$[0.011]$} & & {$[0.057]$} & & {$[0.184]$} \\
\hline Building characteristics & yes & yes & yes & yes & yes & yes \\
\hline Location fixed effects & yes & yes & yes & yes & yes & yes \\
\hline Observations & 4,282 & 4,282 & 11,849 & 11,849 & 5,522 & 5,522 \\
\hline $\mathrm{R}^{2}$ & 0.54 & 0.54 & 0.40 & 0.40 & 0.43 & 0.43 \\
\hline Adj. $R^{2}$ & 0.41 & 0.41 & 0.29 & 0.29 & 0.21 & 0.21 \\
\hline
\end{tabular}

Notes: Table 2.6 shows the results from a propensity score weighted regression model using the logarithm of effective rent per square foot as dependent variable. Standard errors clustered at the zip code level in brackets. Significance at the $0.10,0.05$, and 0.01 level is indicated by ${ }^{*}, * *$, and ${ }^{* * *}$, respectively.

External property management seems most salient and beneficial for Class B buildings. Salient, since external property management is quite common for that building class, and that also holds for distant ownership. Beneficial, since we find large and statistically significant effects of property management at the state level. Hence, when owners of Class B buildings are further away they benefit more from retaining external property managers. Furthermore, the significant effect we find substantially reduces the distance discount. For example, at the 
Figure 2.3: Effective Rent, Owner Distance, and Property Management (Class B)

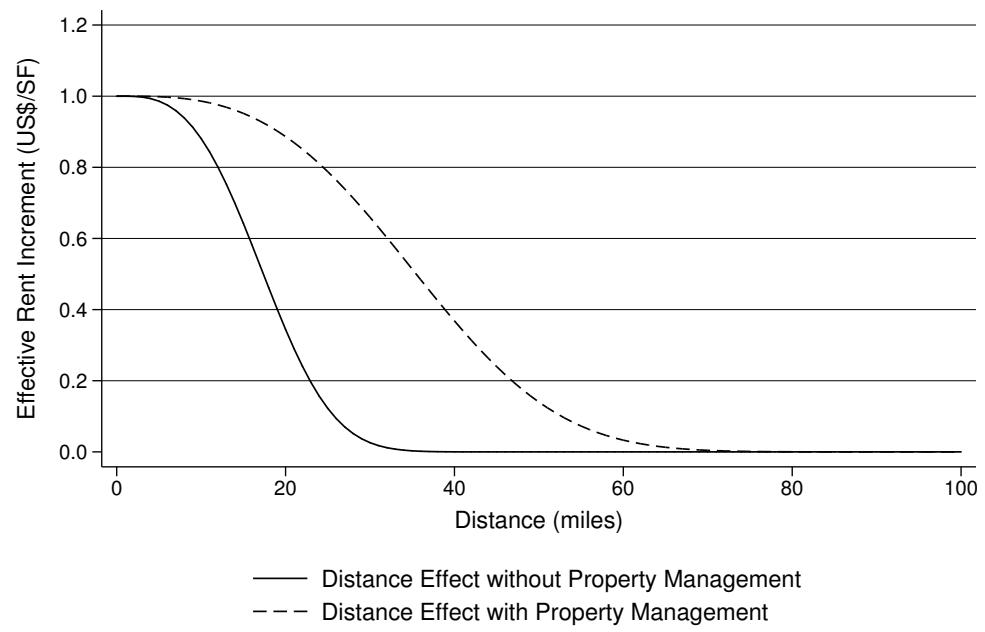

Notes: The above figure displays the non-linear relationship between the effective rent of an asset and owner distance including the mitigating impact of external property management for class $\mathrm{B}$ buildings only.

state level, where we find the strongest effect, the distance discount is 14.9 percent, and external property management reduces that discount by 11.2 percent.

When we look at physical owner distance in miles, we find that external property management only adds value for Class B buildings (Column (4)). Whereas the coefficients of the property manager interaction with owner distance, distance squared and distance to the third power always have signs opposing the distance effects, these coefficients are only statistically significant for Class B buildings. In that case, the size of the coefficients is of such magnitude that much of the owner distance effect is cancelled out. So when property management matters, it seems to matter a lot.

Figure 2.3 further illustrates the effects of property management by outlining the effects of owner distance measured in miles, on the basis of the functional form found in Table 2.6. The graph concerns Class B office buildings only. The solid line in Figure 2.3 depicts the distance effect without property management, and has the same general shape as the one we reported for the total sample in Figure 2.2, albeit with a faster diminishing rent increment for increasing distances. The dashed line represents the distance effect with property management - the rent increment of distance and property management combined. That line suggests that property management allows owners to be located further away from their assets without suffering the consequences in rental discount. For example, an average owner of a building located 24 miles away receives a rent increment of USD 0.20 per square foot, and if she would retain an external property manager, she would still get the same rent when located at a distance of approximately 42 miles. For any owner distance up until 70 miles, the services of an external property manager add value in terms of higher rents. Given that the median owner distance to a Class B office building is 5.2 miles, this is a very significant finding. 
In our final analysis, we aim to shed more light on the importance of the quality of an external property manager. The CoStar database does not provide direct information on management quality, but we do have information about the size of the management companies, and size could be a proxy for quality. Larger property management firms, sometimes operating on a national scale, are likely to be more professional than smaller ones in terms of staff recruitment and training. Firms like Transwestern and Jones Lang LaSalle have a nationwide franchise and an excellent reputation, both in the real estate and in the job market. On the other hand, these bigger firms operate, almost by definition, less local than very small property management organizations, and this chapter shows how important local presence is in the office rental market. So it is not clear ex ante how property managers' size and added value are related.

We estimate the size of a property management organization by looking how often it appears in the dataset, and we have created three different property manager categories by size. Property managers who appear in our dataset only once are categorized as "small". For the remainder set of managers, we count the number of times they appear in the dataset, and then classify those appearing less than the median as "medium" and the remainder as "large". These three groups comprise approximately 34 percent, 33 percent and 33 percent of the sample, respectively, counted by the number of observations.

We find a clear relationship between manager size and owner distance: for the small group, the average owner distance is 242 miles, and that goes up to 380 and 659 miles for the medium and large groups, respectively. We also find that the median distance between the small managers and the buildings they manage is 1 mile, while the median distance between the asset and the medium and large managers is approximately 2.5 miles.

Table 2.7 shows that only small- and medium-sized property managers add value, delivering an average rental premium of 4.3 percent and 4.7 percent, respectively. For the large managers, we do not find a significant rental premium. So even if larger property managers may be associated with more professional organizations, they do not add more value. Local presence, likely leading to better access to local information, seems to be more important. ${ }^{14}$

\subsection{Conclusion and Discussion}

The aim of this study is to investigate three unexplored questions related to owner distance and proximity in the direct commercial real estate market. First, does the U.S. office property market exhibit patterns in owner proximity, and if so, what does that pattern look like? Second, is there a relationship between the economic performance of office buildings and the proximity (or distance) of their owners? Third, do external service providers such as property managers affect that relationship?

\footnotetext{
${ }^{14}$ It is possible that property managers engage in self-selection for certain buildings. Property managers are likely to prefer the management of buildings that are close by, for two reasons. The first is that they are probably aware of the fact that their information advantage is larger for these buildings, and the second is that it improves their quality of life, since it avoids travel time. This is analogous to Dahl and Sorenson (2012), in which entrepreneurs are assumed to stay close to home for informational as well as social reasons. If the latter motivation would be dominant, this would likely decrease the positive rental effect of (nearby) property managers, whereas the former motivation would strengthen the effect. Since we find that local managers add the most value, we infer that self-selection, if present at all, is likely to be motivated by informational considerations.
} 
Table 2.7: Property Management Categories and Local Ownership

\begin{tabular}{|c|c|c|}
\hline & (1) & (2) \\
\hline 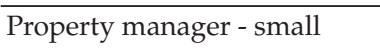 & $0.043^{* * *}$ & $0.044^{* * *}$ \\
\hline (1=yes) & {$[0.013]$} & {$[0.013]$} \\
\hline Property manager - medium & $0.047^{* * *}$ & $0.043^{* * *}$ \\
\hline (1=yes) & {$[0.014]$} & {$[0.014]$} \\
\hline Property manager - large & 0.019 & 0.017 \\
\hline (1=yes) & {$[0.016]$} & {$[0.016]$} \\
\hline \multicolumn{3}{|c|}{ Owner non-local zip code area $-0.068^{* * *}$} \\
\hline (1=yes) & {$[0.016]$} & \\
\hline Owner non-local city & $-0.064^{* * *}$ & \\
\hline (1=yes) & {$[0.013]$} & \\
\hline Owner non-local CBSA & $-0.103^{* * *}$ & \\
\hline (1=yes) & {$[0.025]$} & \\
\hline Owner non-local state & $-0.096^{* * *}$ & \\
\hline (1=yes) & {$[0.014]$} & \\
\hline Owner distance & & $\begin{array}{c}-0.127^{* * *} \\
{[0.039]}\end{array}$ \\
\hline Owner distance ${ }^{2}$ & & $\begin{array}{l}0.075^{* *} \\
{[0.030]}\end{array}$ \\
\hline Owner distance $^{3}$ & & $\begin{array}{c}-0.012^{* *} \\
{[0.005]}\end{array}$ \\
\hline Building characteristics & yes & yes \\
\hline Location fixed effects & yes & yes \\
\hline Observations & 21,653 & 21,653 \\
\hline $\mathrm{R}^{2}$ & 0.41 & 0.41 \\
\hline Adj. $R^{2}$ & 0.35 & 0.34 \\
\hline
\end{tabular}

Notes: This table shows the results from a propensity score weighted regression model using the logarithm of effective rent per square foot as dependent variable. Standard errors clustered at the zip code level in brackets. Significance at the $0.10,0.05$, and 0.01 level is indicated by ${ }^{* * *}$, and ${ }^{* * *}$, respectively.

We address these central questions by analyzing a dataset of 21,653 U.S. office buildings in 2011. We find evidence for a clear pattern in investor proximity: about half the office buildings in our sample have owners located in the same city, and more than 75 percent are located in the same state. Also, if building quality goes up, so does the likelihood of distant ownership, no matter whether we demarcate distant and local owners at the zip code, city, CBSA or state level.

As for the effect of distant ownership on the economic performance of office buildings, we find results that are statistically and economically significant. Far-away ownership comes at a significant discount, varying between 6.4 percent and 10.1 percent for the sample as a whole, depending on the definition of distance. This implies that the average office building's value goes down with approximately USD 1.3-2.1 million when the owner is far away. Building quality plays an important role in this: moving away from high-quality buildings increases the negative rent effects related to owner distance. For Class $\mathrm{C}$ buildings, average distance discounts are as high as 22.1 percent. When we measure owner distance linearly in miles, we also find a negative effect of distance on rent levels. The marginal effect is strong at short distances, and 
then gradually diminishes as distance increases, reducing to zero for distances of 80 miles and more.

Regarding our third research question, we find that external property managers are most likely to be employed by far-away property owners. This seems to be justified: we find that the premium associated with their presence tends to be higher if the owner is far away, but this effect is only visible in Class B office buildings. Moreover, we find that small property management firms, which are more closely located to the properties they manage, add more value. So certain property managers reduce the owner distance discount, enabling owners to be located further from their buildings while sacrificing less rent.

Our findings have important implications for the construction of office portfolios. Diversification has been called the only free lunch, but our results show that even this meal comes with a bill. Diversifying across the nation may still be best from a pure risk reduction point of view, but may not lead to optimal risk-return outcomes. Distant owners seem to receive lower returns on their asset, not just because they get a lower rent, but also because they overpay (Ling et al., 2014). This implies a trade-off between the risk reduction effect of regional diversification and the benefits of local specialization. Building owners manage this trade-off by selecting on asset quality and by retaining external property managers. 


\section{Appendix}

\section{A Main Results for the 50 Largest CBSAs}

Table A.1: Property Management and Local Ownership, CBSA Top 50

\begin{tabular}{|c|c|c|c|c|}
\hline & (1) & (2) & (3) & (4) \\
\hline \multirow{2}{*}{ Property manager (1=yes) } & & & 0.012 & $0.026^{* *}$ \\
\hline & & & {$[0.016]$} & [0.012] \\
\hline \multirow[t]{2}{*}{ Owner non-local zip code area ( $1=y e s)$} & $-0.062^{* * *}$ & & $-0.071^{* * *}$ & \\
\hline & {$[0.017]$} & & {$[0.021]$} & \\
\hline \multirow[t]{2}{*}{ Owner non-local city (1=yes) } & $-0.063^{* * *}$ & & $-0.068^{* * *}$ & \\
\hline & {$[0.014]$} & & {$[0.018]$} & \\
\hline \multirow[t]{2}{*}{ Owner non-local CBSA (1=yes) } & $-0.113^{* * *}$ & & $-0.124^{* * *}$ & \\
\hline & {$[0.028]$} & & {$[0.044]$} & \\
\hline \multirow[t]{2}{*}{ Owner non-local state (1=yes) } & $-0.090^{* * *}$ & & $-0.126^{* * *}$ & \\
\hline & {$[0.014]$} & & {$[0.022]$} & \\
\hline \multirow[t]{2}{*}{ Owner distance } & & $-0.101^{* * *}$ & & $-0.245^{* * *}$ \\
\hline & & {$[0.038]$} & & {$[0.073]$} \\
\hline \multirow[t]{2}{*}{ Owner distance $^{2}$} & & $0.057^{* *}$ & & $0.164^{* * *}$ \\
\hline & & {$[0.029]$} & & {$[0.061]$} \\
\hline \multirow[t]{2}{*}{ Owner distance ${ }^{3}$} & & -0.008 & & $-0.024^{* *}$ \\
\hline & & {$[0.005]$} & & {$[0.012]$} \\
\hline Owner non-local zip code area * & & & 0.027 & \\
\hline Property manager (1=yes) & & & {$[0.031]$} & \\
\hline Owner non-local city * & & & 0.018 & \\
\hline Property manager (1=yes) & & & {$[0.024]$} & \\
\hline Owner non-local CBSA * & & & 0.025 & \\
\hline Property manager (1=yes) & & & {$[0.049]$} & \\
\hline Owner non-local state * & & & $0.057^{* *}$ & \\
\hline Property manager (1=yes) & & & {$[0.025]$} & \\
\hline Owner distance * & & & & $0.190^{* *}$ \\
\hline Property manager & & & & {$[0.078]$} \\
\hline Owner distance ${ }^{2 *}$ & & & & $-0.147^{* *}$ \\
\hline Property manager & & & & {$[0.064]$} \\
\hline Owner distance ${ }^{3 *}$ & & & & $0.023^{*}$ \\
\hline Property manager & & & & {$[0.012]$} \\
\hline Building characteristics & yes & yes & yes & yes \\
\hline Location fixed effects & yes & yes & yes & yes \\
\hline Observations & 18,343 & 18,343 & 18,343 & 18,343 \\
\hline$R^{2}$ & 0.40 & 0.40 & 0.41 & 0.40 \\
\hline Adj. $R^{2}$ & 0.35 & 0.35 & 0.35 & 0.35 \\
\hline
\end{tabular}

Notes: This table shows the results from a propensity score weighted regression model using the logarithm of effective rent per square foot as dependent variable. Standard errors clustered at the zip code level in brackets. Significance at the 0.10, 0.05 , and 0.01 level is indicated by ***, and ${ }^{* * *}$, respectively. 


\section{B Definition of Building Classifications}

CoStar uses the following definitions for the building quality designation:

- Class A Office: in general, a class A building is an extremely desirable investment-grade property with the highest quality construction and workmanship, materials and systems, significant architectural features, the highest quality/expensive finish and trim, abundant amenities, first rate maintenance and management; usually occupied by prestigious tenants with above average rental rates and in an excellent location with exceptional accessibility. They are most eagerly sought by international and national investors willing to pay a premium for quality and are often designed by architects whose names are immediately recognizable. A building meeting these criteria is often considered to be a landmark, either historical, architectural or both. It may have been built within the last 5 to 10 years, but if it is older, it has been renovated to maintain its status and provide its many amenities. Buildings of this stature can be one-of-a-kind with unique shape and floor plans, notable architectural design, excellent and possibly outstanding location and a definite market presence.

- Class B Office: in general, a class B building offers more utilitarian space without special attractions. It will typically have ordinary architectural design and structural features, with average interior finish, systems, and floor plans, adequate systems and overall condition. It will typically not have the abundant amenities and location that a class A building will have. This is generally considered to be more of a speculative investment. The maintenance, management and tenants are average to good, although, Class B buildings are less appealing to tenants and may be deficient in a number of respects including floor plans, condition and facilities. They therefore attract a wide range of users with average rents. They lack prestige and must depend chiefly on lower price to attract tenants and investors. Typical investors are some national but mostly local.

- Class C Office: in general, a class C building is a no-frills, older building that offers basic space. The property has below-average maintenance and management, a mixed or low tenant prestige, and inferior elevators and mechanical/electrical systems. As with Class B buildings, they lack prestige and must depend chiefly on lower price to attract tenants and investors. 


\section{Propensity Score Weighting Procedure}

The propensity score estimation uses a logit model to explain the determinants of external property management. Table C.1 summarizes the results for this logit regression using different specifications. Column (1) - the most extensive model — shows that larger, younger and higher quality buildings are more likely to have an external property manager. However, this specification does not satisfy the balancing property of the propensity score estimation. Specifically, the balancing property tests whether the "treated" managed buildings have the same average propensity score within each block as compared to the "untreated" non-managed buildings.

The specification as displayed in column (2) uses the most elaborate specification - in terms of the number of included variables - that satisfies all the criteria of the propensity score estimation. In line with our earlier findings, high quality buildings are more likely to have an external property manager. When measuring age with different age brackets, younger buildings are less likely to have an external property manager as compared to buildings older than 20 years. Moreover, this model is able to explain about 7 percent of the likelihood of having a property manager as compared to 10 percent for the model displayed in column (1).

The reduced model in column (3) - satisfying all estimation criteria for the propensity score - shows that building size is one of the most important determinants of having an external property manager. This specification explains most of the likelihood of employing an external property manager — some 9 percent — without violating any of the estimation criteria. Therefore, we use the estimated propensity scores from this model as weights throughout all the reported analyses.

Table C.2 documents the average building characteristics after applying the resulting propensity score weights from the three specifications reported in Table C.1. In general, propensity score weighting reduces the differences between the externally managed and non-managed samples, as demonstrated in columns (5), (7), (9), and (11). However, regardless of the propensity score specification that we employ, most of the differences - in terms of observable characteristics between the two samples remain significant.

Figure C.1 displays the distribution of the propensity score weights for the whole sample, the externally managed and non-managed samples. The region of common support is [0.05, 0.89] which is distributed across 13 blocks. The mean weight is 34 percent and the standard deviation is 16 percent. The propensity score density is positively skewed with a measure of 0.50. The dashed and dotted lines in Figure C.1 indicate the area of common support for the two samples. The overlap confirms that there are managed and non-managed buildings with similar weights.

Table C.3 documents our main results to illustrate the robustness of our results with respect to the specification of the propensity score weights. We re-estimate our model by applying the different propensity score weights as discussed in Table C.1.

The specification in the first column uses no propensity score weighting and shows a distance discount in the range of 7.9 to 14.8 percent. Columns (2)-(4) apply the propensity score weights as discussed in Table C.1. The results for distant ownership are in line with those without applying propensity score weighting with a discount ranging from 6.3 to 13 percent.

As another robustness test we include nearest neighbor matching in column (5). The discount 
associated with owner distance is negative and statistically significant in this model as well. More importantly, the impact of external property management is stable across all specifications, indicating that external property management is only of added value when the owner is out of state. 
Figure C.1: Distribution of Propensity Scores

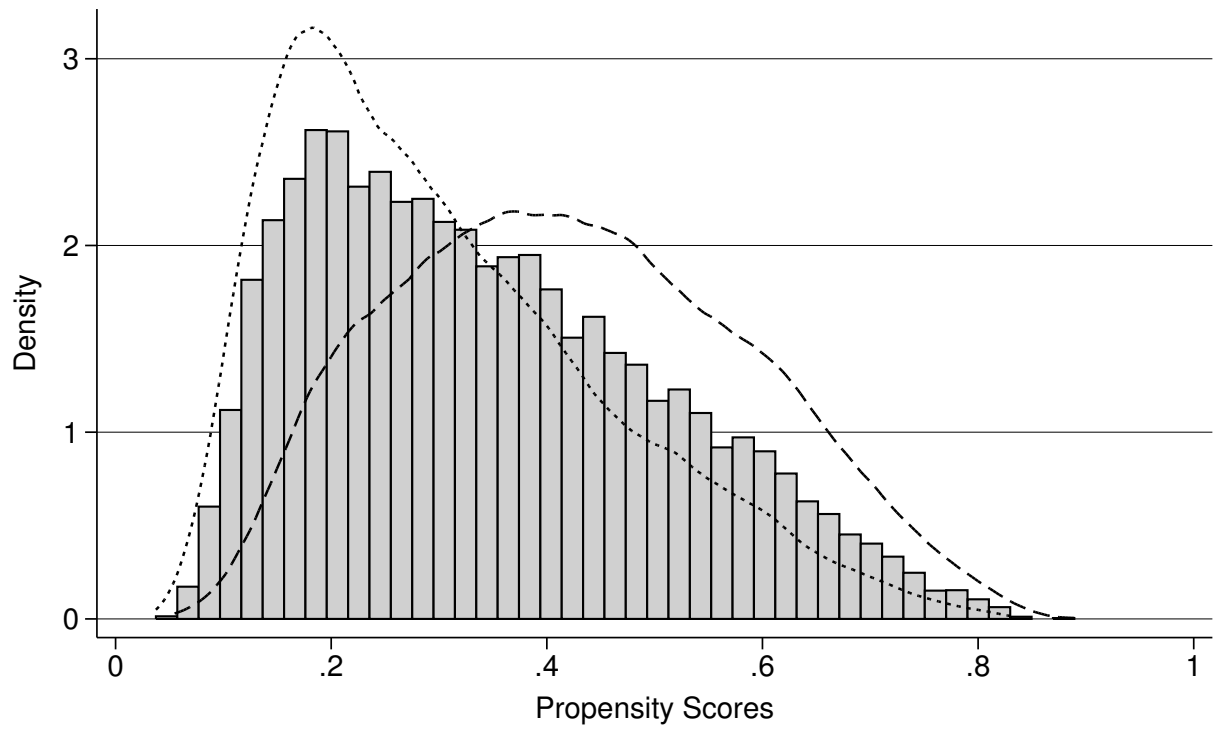

$\square$ Whole Sample - - - Managed Buildings ...... Non-Managed Buildings 
Table C.1: The Determinants of External Property Management

\begin{tabular}{|c|c|c|c|}
\hline & (1) & (2) & (3) \\
\hline \multirow[t]{2}{*}{ Log size (thousand sq. ft.) } & $0.562^{* * *}$ & & $0.589^{* * *}$ \\
\hline & {$[0.020]$} & & {$[0.013]$} \\
\hline Stories (number) & $\begin{array}{c}-0.016^{* * *} \\
{[0.003]}\end{array}$ & & \\
\hline \multicolumn{4}{|l|}{ Building class ( $1=$ yes) } \\
\hline \multirow[t]{2}{*}{ Class A } & $0.254^{* * *}$ & $1.797^{* * *}$ & \\
\hline & {$[0.063]$} & {$[0.048]$} & \\
\hline \multirow[t]{2}{*}{ Class B } & $0.233^{* * *}$ & $0.828^{* * *}$ & \\
\hline & {$[0.044]$} & {$[0.040]$} & \\
\hline Age (years) & $\begin{array}{c}-0.002^{* * *} \\
{[0.001]}\end{array}$ & & \\
\hline \multicolumn{4}{|l|}{ Age (1=yes) } \\
\hline$\leq 10$ years & & $\begin{array}{c}-0.885^{* * *} \\
{[0.053]}\end{array}$ & \\
\hline $11-20$ years & & $\begin{array}{c}-0.302^{* * *} \\
{[0.049]}\end{array}$ & \\
\hline Renovated (1=yes) & $\begin{array}{l}0.183^{* * * *} \\
{[0.041]}\end{array}$ & $\begin{array}{l}0.300^{* * *} \\
{[0.037]}\end{array}$ & \\
\hline On-site amenities (1=yes) & $\begin{array}{l}0.168^{* * *} \\
{[0.039]}\end{array}$ & & $\begin{array}{l}0.132^{* * *} \\
{[0.038]}\end{array}$ \\
\hline Public transport (1=yes) & $\begin{array}{l}0.157^{* * *} \\
{[0.050]}\end{array}$ & & $\begin{array}{c}-0.025^{* * * *} \\
{[0.043]}\end{array}$ \\
\hline Constant & $\begin{array}{c}-2.863^{* * *} \\
{[0.069]}\end{array}$ & $\begin{array}{c}-1.432^{* * *} \\
{[0.035]}\end{array}$ & $\begin{array}{c}-2.856^{* * *} \\
{[0.051]}\end{array}$ \\
\hline Observations & 21,653 & 21,653 & 21,653 \\
\hline Psuedo- $R^{2}$ & 0.10 & 0.07 & 0.09 \\
\hline
\end{tabular}

Notes: This table shows the resulst from a logistic regression model using a binary variable for property management as dependent variable. Standard deviations in brackets. Standard errors in brackets. Significance at the 0.10, 0.05, and 0.01 level is indicated by $* * *$, and $* * *$, respectively. 


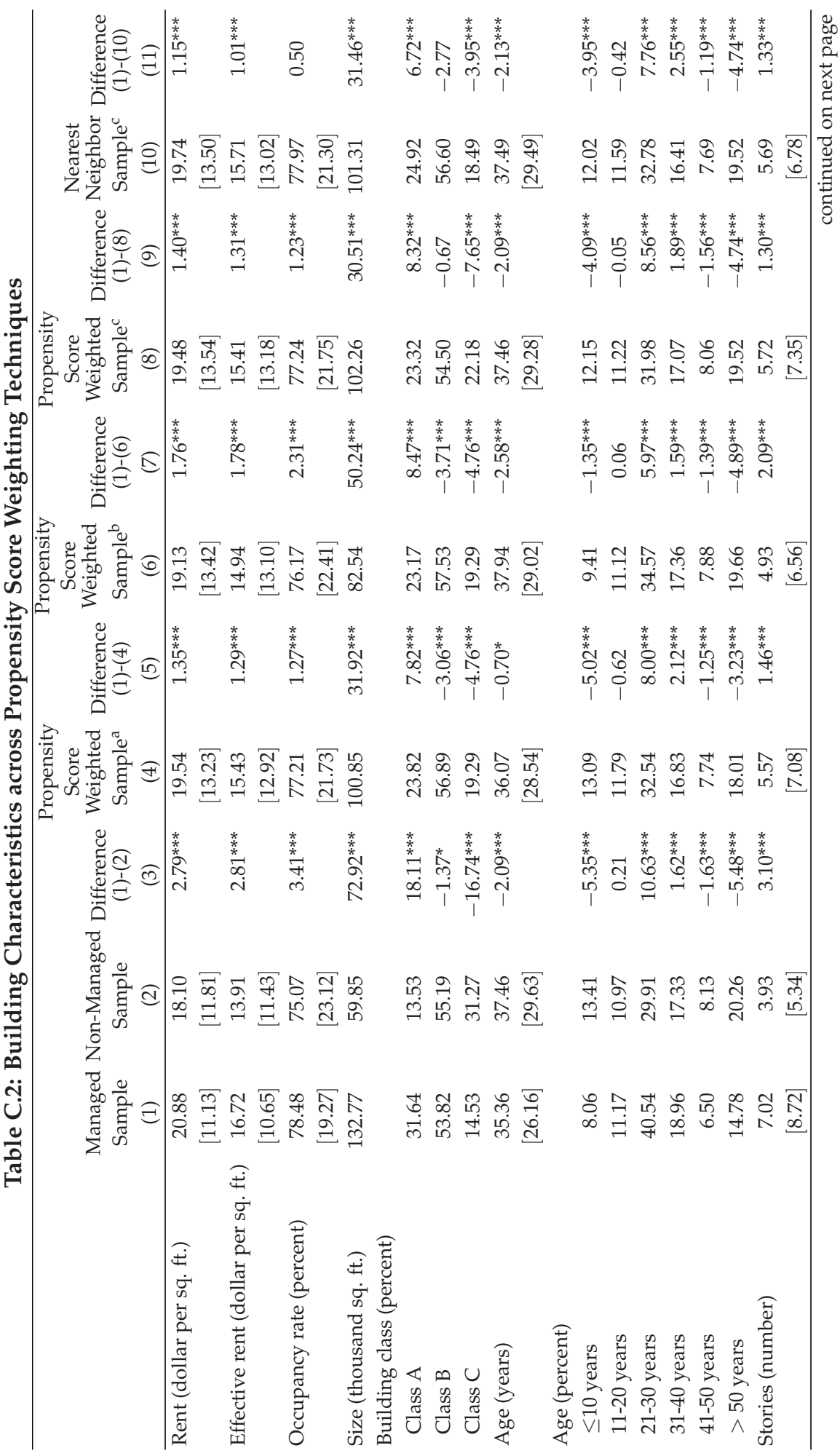




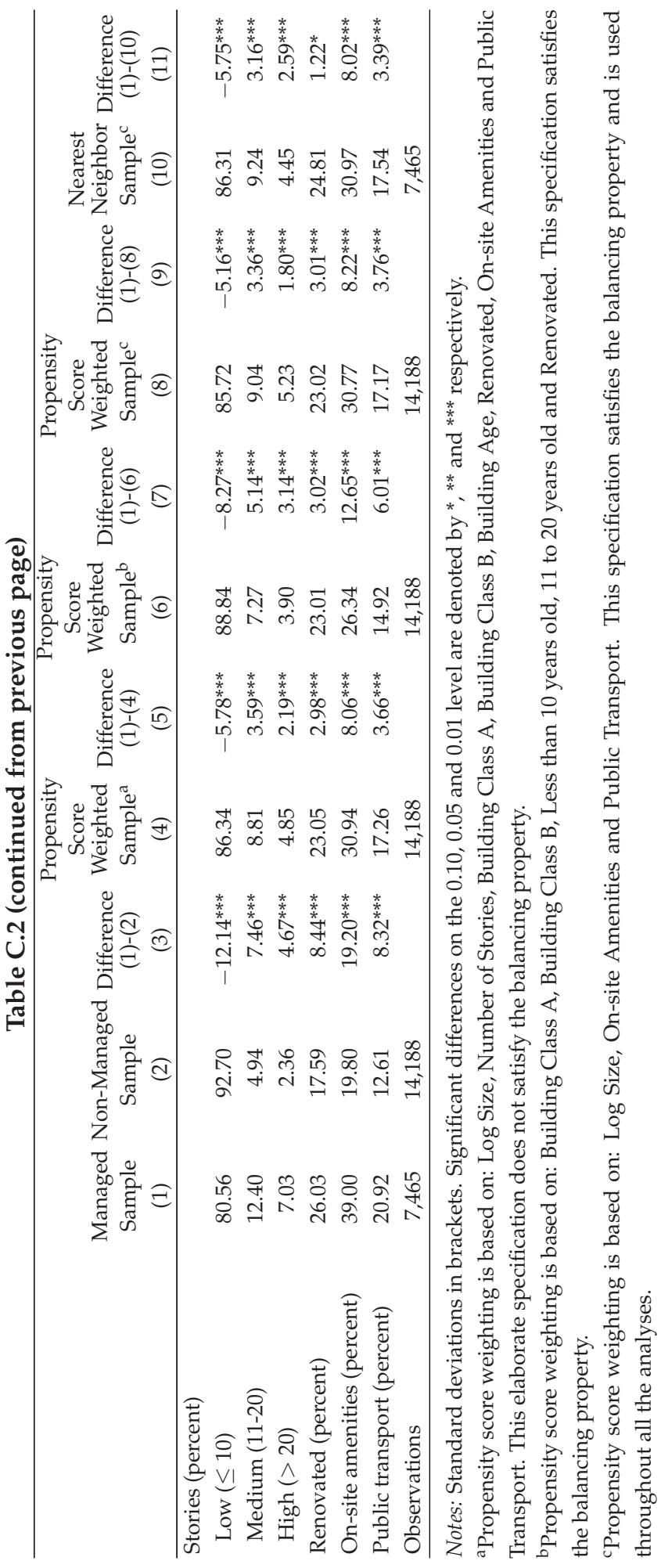


Table C.3: Propensity Score Specificaitons

\begin{tabular}{|c|c|c|c|c|c|}
\hline & NO PSW & PSW $^{\mathrm{a}}$ & $\mathrm{PSW}^{\mathrm{b}}$ & $\mathrm{PSW}^{\mathrm{c}}$ & $\begin{array}{c}\text { Nearest } \\
\text { Neighbor }^{c}\end{array}$ \\
\hline \multirow[t]{2}{*}{ Property manager (1=yes) } & 0.004 & 0.013 & 0.013 & 0.013 & 0.022 \\
\hline & {$[0.018]$} & {$[0.016]$} & {$[0.017]$} & {$[0.016]$} & {$[0.020]$} \\
\hline \multirow[t]{2}{*}{ Owner non-local zip code area ( $1=y e s)$} & $-0.090^{* * *}$ & $-0.075^{* * *}$ & $-0.075^{* * *}$ & $-0.075^{* * *}$ & $-0.048^{*}$ \\
\hline & {$[0.022]$} & {$[0.019]$} & {$[0.020]$} & {$[0.019]$} & {$[0.027]$} \\
\hline \multirow[t]{2}{*}{ Owner non-local city (1=yes) } & $-0.079^{* * *}$ & $-0.063^{* * *}$ & $-0.064^{* * *}$ & $-0.067^{* * *}$ & $-0.049^{* *}$ \\
\hline & {$[0.018]$} & {$[0.017]$} & {$[0.018]$} & {$[0.017]$} & {$[0.023]$} \\
\hline \multirow[t]{2}{*}{ Owner non-local CBSA (1=yes) } & $-0.105^{* * *}$ & $-0.103^{* * *}$ & $-0.095^{* * *}$ & $-0.103^{* * *}$ & $-0.117^{* * *}$ \\
\hline & {$[0.033]$} & {$[0.036]$} & {$[0.035]$} & {$[0.035]$} & {$[0.044]$} \\
\hline \multirow[t]{2}{*}{ Owner non-local state (1=yes) } & $-0.148^{* * *}$ & $-0.125^{* * *}$ & $-0.130^{* * *}$ & $-0.125^{* * *}$ & $-0.129^{* * *}$ \\
\hline & {$[0.023]$} & {$[0.020]$} & {$[0.020]$} & {$[0.020]$} & {$[0.027]$} \\
\hline Owner non-local zip code area * & 0.036 & 0.023 & 0.021 & 0.024 & -0.003 \\
\hline Property manager (1=yes) & {$[0.034]$} & {$[0.031]$} & {$[0.034]$} & {$[0.031]$} & {$[0.038]$} \\
\hline Owner non-local city * & 0.023 & 0.011 & 0.012 & 0.014 & -0.003 \\
\hline Property manager (1=yes) & {$[0.026]$} & {$[0.024]$} & {$[0.025]$} & {$[0.024]$} & {$[0.029]$} \\
\hline Owner non-local CBSA * & -0.008 & 0.006 & 0.001 & 0.007 & -0.002 \\
\hline Property manager (1=yes) & {$[0.041]$} & {$[0.042]$} & {$[0.041]$} & {$[0.042]$} & {$[0.050]$} \\
\hline Owner non-local state * & $0.084^{* * *}$ & $0.055^{* *}$ & $0.057^{* *}$ & $0.054^{* *}$ & $0.059^{* *}$ \\
\hline Property manager (1=yes) & {$[0.026]$} & {$[0.023]$} & {$[0.025]$} & {$[0.023]$} & {$[0.029]$} \\
\hline \multirow[t]{2}{*}{ Log size (thousand sq. ft.) } & $0.137^{* * *}$ & $0.126^{* * *}$ & $0.139^{* * *}$ & $0.124^{* * *}$ & $0.130^{* * *}$ \\
\hline & {$[0.009]$} & {$[0.008]$} & {$[0.009]$} & {$[0.008]$} & {$[0.011]$} \\
\hline \multicolumn{6}{|l|}{ Stories (1=yes) } \\
\hline \multirow[t]{2}{*}{ Medium (10-20) } & -0.019 & -0.006 & -0.014 & -0.005 & -0.002 \\
\hline & {$[0.020]$} & {$[0.018]$} & {$[0.019]$} & {$[0.018]$} & {$[0.020]$} \\
\hline \multirow[t]{2}{*}{$\operatorname{High}(>20)$} & -0.025 & -0.014 & -0.029 & -0.010 & 0.003 \\
\hline & {$[0.032]$} & {$[0.029]$} & {$[0.030]$} & {$[0.029]$} & {$[0.033]$} \\
\hline \multicolumn{6}{|l|}{ Building class (1=yes) } \\
\hline \multirow[t]{2}{*}{ Class A } & $0.167^{* * *}$ & $0.190^{* * *}$ & $0.168^{* * *}$ & $0.192^{* * *}$ & $0.177^{* * *}$ \\
\hline & {$[0.026]$} & {$[0.024]$} & {$[0.026]$} & {$[0.024]$} & [0.029] \\
\hline \multirow[t]{2}{*}{ Class B } & $0.058^{* * *}$ & $0.077^{* * *}$ & $0.062^{* * *}$ & $0.077^{* * *}$ & $0.067^{* * *}$ \\
\hline & {$[0.017]$} & {$[0.016]$} & {$[0.018]$} & {$[0.016]$} & {$[0.022]$} \\
\hline \multicolumn{6}{|l|}{ Age (1=yes) } \\
\hline \multirow[t]{2}{*}{$\leq 10$ years } & $0.091^{* * *}$ & $0.113^{* * *}$ & $0.096^{* * *}$ & $0.115^{* * *}$ & $0.083^{* *}$ \\
\hline & {$[0.029]$} & {$[0.027]$} & {$[0.028]$} & {$[0.027]$} & {$[0.035]$} \\
\hline \multirow[t]{2}{*}{$11-20$ years } & $0.058^{*}$ & $0.082^{* * *}$ & $0.071^{* * *}$ & $0.084^{* * *}$ & 0.054 \\
\hline & {$[0.030]$} & {$[0.027]$} & {$[0.027]$} & {$[0.027]$} & {$[0.034]$} \\
\hline \multirow[t]{2}{*}{ 21-30 years } & 0.004 & 0.020 & 0.009 & 0.021 & 0.004 \\
\hline & {$[0.025]$} & {$[0.023]$} & {$[0.023]$} & {$[0.023]$} & {$[0.028]$} \\
\hline \multirow[t]{2}{*}{$31-40$ years } & -0.007 & -0.002 & -0.003 & -0.001 & -0.009 \\
\hline & {$[0.024]$} & {$[0.023]$} & {$[0.022]$} & {$[0.023]$} & {$[0.028]$} \\
\hline \multirow[t]{2}{*}{$41-50$ years } & -0.018 & -0.004 & -0.012 & 0.000 & -0.007 \\
\hline & {$[0.028]$} & {$[0.024]$} & {$[0.026]$} & {$[0.024]$} & {$[0.032]$} \\
\hline \multirow[t]{2}{*}{ Renovated (1=yes) } & $-0.027^{*}$ & -0.021 & $-0.031^{* *}$ & -0.019 & -0.024 \\
\hline & {$[0.015]$} & {$[0.013]$} & {$[0.014]$} & {$[0.013]$} & {$[0.015]$} \\
\hline \multirow[t]{2}{*}{ On-site amenities (1=yes) } & $0.032^{* *}$ & $0.032^{* *}$ & $0.023^{*}$ & $0.034^{* * *}$ & 0.023 \\
\hline & {$[0.014]$} & {$[0.013]$} & {$[0.013]$} & {$[0.013]$} & {$[0.014]$} \\
\hline
\end{tabular}


Table C.3 (continued from previous page)

\begin{tabular}{lccccc}
\hline & NO PSW & PSW $^{\mathrm{a}}$ & PSW $^{\mathrm{b}}$ & PSW $^{\mathrm{c}}$ & $\begin{array}{c}\text { Nearest } \\
\text { Neighbor }^{\mathrm{c}}\end{array}$ \\
\hline Public transport (1=yes) & 0.005 & 0.019 & 0.015 & 0.021 & 0.004 \\
& {$[0.028]$} & {$[0.027]$} & {$[0.025]$} & {$[0.027]$} & {$[0.031]$} \\
Building characteristics & yes & yes & yes & yes & yes \\
Location fixed effects & yes & yes & yes & yes & yes \\
Observations & 21,653 & 21,653 & 21,653 & 21,653 & 14,930 \\
$\mathrm{R}^{2}$ & 0.37 & 0.41 & 0.39 & 0.41 & 0.45 \\
Adj. $\mathrm{R}^{2}$ & 0.30 & 0.34 & 0.33 & 0.35 & 0.36 \\
\hline
\end{tabular}

Notes: This table shows the results from a propensity score weighted regression model using the logarithm of effective rent per square foot as dependent variable. Standard errors clustered at the zip code level in brackets. Significance at the $0.10,0.05$, and 0.01 level is indicated by *, **, and ${ }^{* * *}$, respectively.

a Propensity score weighting is based on: Log Size, Number of Stories, Building Class A, Building Class B, Building Age, Renovated, On-site Amenities and Public Transport. This elaborate specification does not satisfy the balancing property.

bPropensity score weighting is based on: Building Class A, Building Class B, Less than 10 years old, 11 to 20 years old and Renovated. This specification satisfies the balancing property. 'Propensity score weighting is based on: Log Size, On-site Amenities and Public Transport. This specification satisfies the balancing property and is used throughout all the analyses. 


\section{Owner Distance Distribution Figures}

Figure D.1: Distribution of Owner Distance, by Building Class Panel A: Building Class A

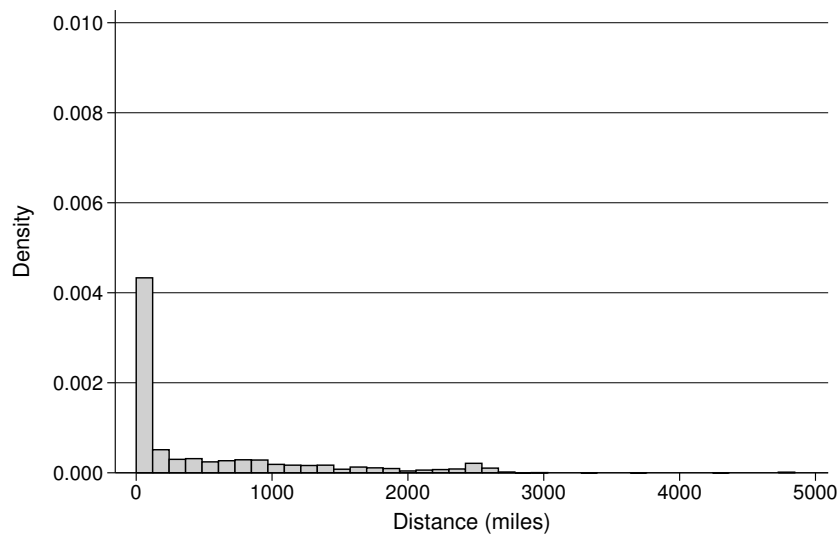

Panel B: Building Class B

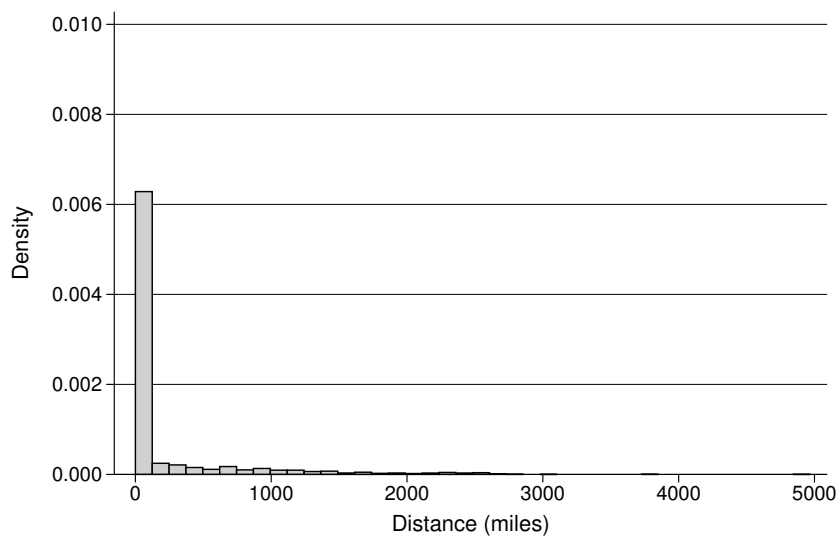

Panel C: Building Class C

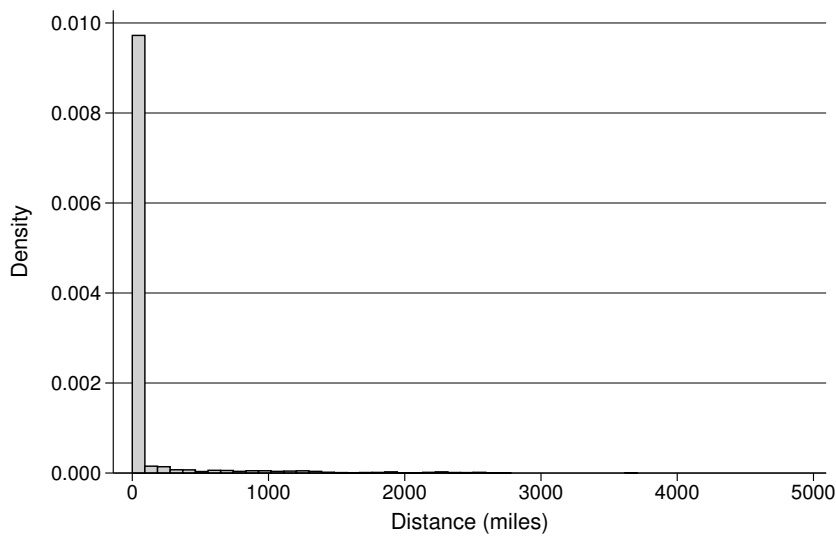


Figure D.2: Distribution of Owner Distance, by Property Management Category Panel A: Managed Buildings

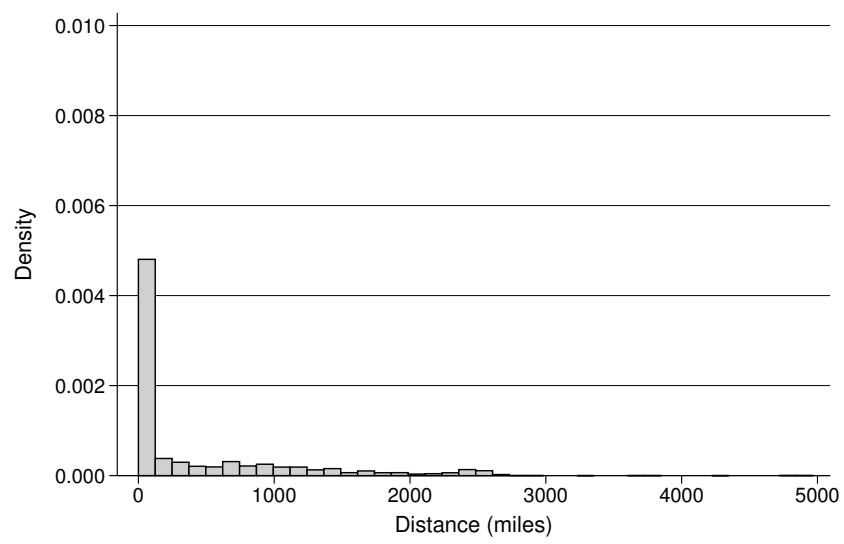

Panel B: Non-Managed Buildings

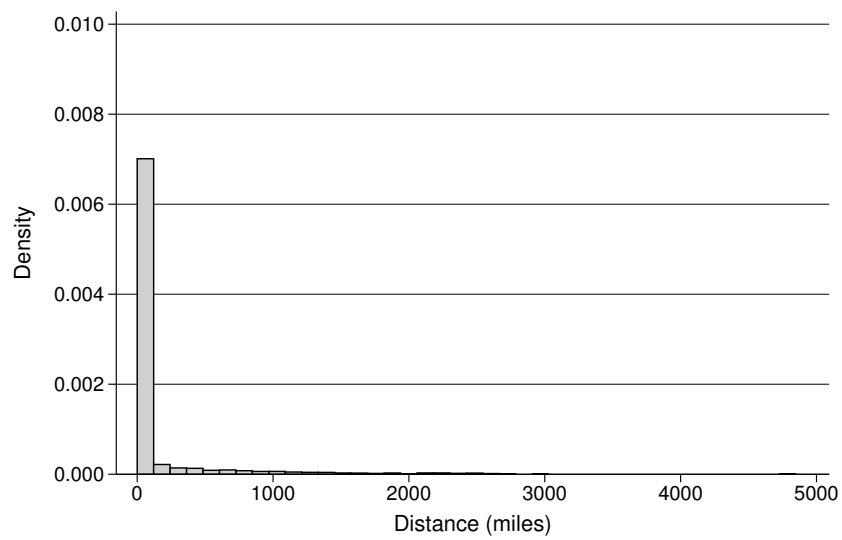




\section{E Impact of Property Management}

Table E.1: Property Management and Local Ownership

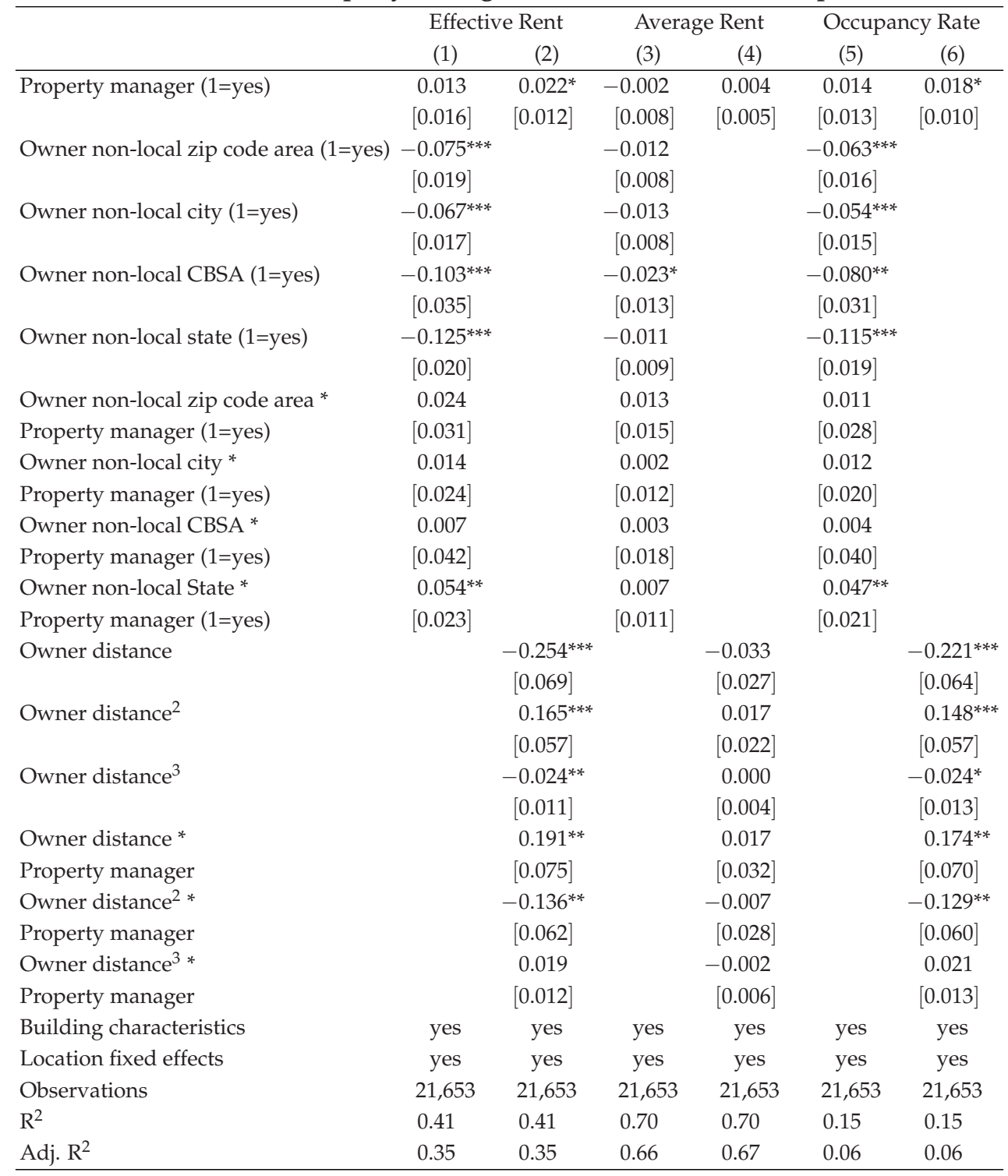

Notes: This table shows the results from a propensity score weighted regression model using the logarithm of effective rent per square foot, logarithm of average rent per square foot, or occupancy rate as dependent variable. Standard errors clustered at the zip code level in brackets. Significance at the 0.10, 0.05 , and 0.01 level is indicated by ${ }^{* * *}$, and ${ }^{* * *}$, respectively. 


\section{Chapter 3}

\section{Intermediation in the Commercial Real Estate Market: Is Bigger Better?*}

\subsection{Introduction}

Real estate brokers, leasing agents and property managers play a pivotal role in the U.S. commercial property industry. Investors, both institutional and private, almost always retain the services of such intermediaries when buying, managing and selling assets. To illustrate their importance: in the institution-grade U.S. commercial real estate market alone, in 2015 the total transaction volume was USD 534 billion. $^{2}$

Despite the key role of intermediaries in one of the largest asset markets, the performance and value-add of commercial real estate transaction advisors has hardly been investigated. For residential real estate, more is known about advisor performance (see Levitt and Syverson, 2008 for a well-known illustration), but the U.S. commercial real estate brokerage market differs fundamentally from its residential counterpart. For example, it has no equivalent to the residential multiple listing service to share market information. Instead, commercial real estate brokerage firms share information on their listings more informally, through newsletters and bilateral meetings with (potential) clients. Moreover, the information and representation function of commercial brokerage is often more unbundled as compared to residential real estate transactions, and clients tend to be professional organizations. This might explain the relatively limited concern about agency problems in commercial real estate transactions (Micelli et al., 2000).

Commission rates for commercial real estate brokerage average 2.5-4 percent, which is lower than the prevailing 5-6 percent in the residential real estate market (MacIntosh, 1996). However, commission rates for commercial property transactions tend to be more flexible and negotiable (Wachter, 1987). But, the question remains whether commercial real estate advisors add value to justify these fees, and especially whether the most active firms add most value. If more active brokers have more extensive, more powerful networks, one could expect that the most active buying brokers help their clients buy buildings for lower purchase prices, and that the most active listing brokers help their clients realize higher selling prices.

\footnotetext{
*This chapter is co-authored with Piet Eichholtz (Maastricht University).

${ }^{2}$ Real Capital Analytics, 2016.
} 
In the commercial real estate market leasing agents and property managers are often employed to manage the leasing and day-to-day operations of an asset. The commission for these service providers differs slightly from the advisors that are involved in a commercial property transaction. Typically, leasing agents receive a commission in the height of 3-4 percent of the face value of a newly signed lease. Property managers receive, on average, 3-6 percent of effective gross income of the asset, depending on asset size and management intensity (Ling and Archer, 2010). Despite the difference in commission structure the question whether these service providers add value for their clients remains. One could expect that the most active leasing agents are better at negotiating rents, and that the most active property managers are better at maintaining the quality of an asset - thereby indirectly influencing the cash flow of a building.

In order to shed empirical light on this research question, we employ a sample of some 66,000 lease contracts observed in the third quarter of 2015 and a sample of almost 52,000 transactions of U.S. commercial offices for the period of the first quarter of 1990 through the third quarter of 2015. This allows us to investigate the impact of real estate transaction advisors on the cash flows and transaction values of commercial office space. The database at hand also contains detailed information on other variables known to affect building rents and values, alleviating concerns about endogeneity.

We document that the most active brokers tend to be involved in higher quality assets, and that these transaction advisors work on the most complicated deals. The main conclusion of the chapter is that bigger is not always better when it comes to commercial real estate transaction advisory services. On the rental market, we find that more active leasing agents and property managers add consistent value in maximizing annual rents. We document a rental premium of 1.9-2.4 percent, after controlling for a broad set of building quality characteristics like size, quality classification, age, renovation status and location, which is consistent for different specifications.

For office sales transactions, we document that advisor transaction activity matters. However, the direction of the effect is not as one would expect. Instead of a lower buying price, retaining a "Top 50" buying broker is associated with a price premium of 1.3 percent, again after controlling for other building and location characteristics. We find a similar counterintuitive effect for the presence of a selling broker: buildings sold by a "Top 50" or more active selling broker sell at a discount of 2 percent, on average. This begs the question why the most active transaction advisors have the market share they have, with the underperformance in transaction prices. The answer may reside in transaction speed: once building owners have decided to sell an asset, they want to sell it fast, and we find that the most active brokers help sell buildings up to 9 days faster than boutique advisors, compared to a median time on the market of approximately 200 days - some five percent.

In the remainder of this chapter, we first discuss the literature regarding scale effects in business-to-business and real estate services. We then present the data sources and sample statistics in section three, followed by a section discussing the method we employ for the empirical analysis. Section five presents the results, first for rental transactions, and subsequently for sales. Section six concludes. 


\subsection{Literature}

Outside of real estate, the role and performance of advisors in asset transactions has been documented quite extensively, mostly in the mergers and acquisitions literature. Bowers and Miller (1990) analyze the choice of investment bank on shareholder wealth creation in mergers and acquisitions. The authors document that in acquisitions where either the bidder or the target engages a first-tier investment bank, the total incremental wealth is higher compared to neither firm employing a first-tier investment bank.

In contrast, McLaughlin (1992) documents that bidding firms using low-quality advisors offer lower premiums and experience higher excess returns at the announcement of a tender offer. The author interprets these findings as support for high-quality investment bankers either encouraging their clients to make higher bids leading to a subsequent reduction in firm value or that high-quality bankers are associated with more complex transactions that require a higher premium and inherently have a lower benefit to the bidding firm. In line with this hypothesis, Servaes and Zenner (1996) conclude that bidding firms are more likely to employ an investment bank when the transaction is more complex, the client has less prior experience with acquisitions, and the acquisition is a takeover. Furthermore, the authors find no evidence for bidding firms obtaining higher returns when an investment bank is involved in the deal.

Rau (2000) shows that although first-tier investment banks complete a larger share of their tender offers, they achieve lower abnormal announcement-period returns for their clients relative to their second- and third-tier competitors. Consistent with McLaughlin (1992), Rau finds that the premium in tender offers is higher when a first- or second-tier investment bank is involved. However, the premium observed in mergers does not differ across investment bank categories. Similar to these findings, Hunter and Jagtiani (2003) document that top-tier advisors are more likely to complete the deal and need less time, although the post-merger gains from the deal to the acquirer are negatively related to advisor quality. Ismail (2010) also fails to find a relationship between the quality of the advisor and the gains to the bidding firm, target firm, or the combined firm.

Golubov et al. (2012), however, document that top-tier investment banks are associated with higher bidder gains in public acquisitions, but not in case of private or subsidiary deals. The authors stipulate that the increase in bidder returns stems from the ability of top-tier investment banks to identify deals with higher synergies and obtain a larger share of the synergies for the bidding firm. The difference in abnormal returns across acquisition types is attributed to the reputational exposure experienced by investment banks in public deals.

For commercial real estate transactions, there is limited literature investigating the performance of transaction advisors. All existing work on real estate brokerage involves residential real estate. An early study by Sirmans et al. (1991) investigates the extent to which real estate brokers impact the time on the market of residential real estate. Using a sample of 1,225 housing transactions in Baton Rouge, LA, to test their theoretical predictions, the authors document that larger firms sell homes faster than their smaller rivals. However, sellers do not pay higher commissions to list with faster-selling firms. In addition, they conclude that the multiple listing service market is efficient since brokers do not sell their own listings faster than other firms' listings.

Yang and Yavas (1995) study the impact of listing real estate brokers on time on the market 
of single-family homes in State College, PA. The authors employ a sample of 388 homes listed and sold in 1991 on a multiple listing service to determine whether broker characteristics and the commission rate influence the time on the market of a home. The results suggest that neither the commission rate nor the size of the listing company have an impact on time on the market. However, the authors do find that an increase in the number of listings of a broker increases time on the market.

In contrast, a similar study by Jud et al. (1996) finds no significant impact of employing a brokerage firm on time on the market using 2,285 transactions from Greensboro, NC, during the September 1991 to September 1993 time period. The authors conclude that this suggests an efficient flow of information within the multiple listing service market, and that specific agents and firms do not have additional advantages since all information within the multiple listing service is shared.

Turnbull and Dombrow (2007) investigate the impact of firm- and agent-specific characteristics on the selling price and time on the market of homes sold in Baton Rouge, LA. The authors argue that the separation of agent and firm-specific effects is needed due to possible agency conflicts that not only hamper the seller-agent relationship but the agent-brokerage firm relationship as well. The results indicate that there are no apparent economies of scale on the firm level as measured by firm size. However, modest price effects can be observed related to local market knowledge.

Rutherford et al. (2005) examine whether the compensation structure in real estate brokerage services creates agency problems. The authors hypothesize that less informed homeowners may be disadvantaged by real estate agents in the price setting and negotiation process. Using a sample of 306,869 homes sold in Texas over the 1999-2002 period, the authors test whether real estate agents exploit their information advantage. The results indicate that real estate agents do not sell their homes any faster than the homes of their clients. However, they do sell their own assets at a significant premium of 4.5 percent.

Levitt and Syverson (2008) document that better informed residential real estate agents sell their own homes for 3.7 percent more than those of their clients, and keep them on the market 9.5 days longer. Moreover, these effects are larger when the information asymmetry is greater. The authors analyze some 98,000 home sales in Cook County, IL, of which 3,300 are agent-owned homes. The authors acknowledge that these findings are consistent with other explanations, such as differences in discount rates or risk aversion across clients and agents. However, the magnitude of the documented effects is too large for these explanations.

Rutherford and Yavas (2012) examine the use of discount brokers in the residential real estate market and their impact on time on the market, listing, and transaction price. The notion is that transaction costs have an impact on the liquidity and price of an asset. The authors employ a set of 318,221 observations of homes that are sold or withdrawn from the multiple listing service in the metropolitan counties of Texas during the 2002-2007 period. The results indicate that homes listed through a discount broker are less likely to sell, and take longer to sell. However, when the home sells, it sells for the same price relative to homes listed through a traditional broker. The authors conclude that the commission structure has no impact on the transaction price of a home, but has a negative impact on liquidity.

Bernheim and Meer (2013) use an open access multiple listing service platform to measure the effects of brokerage services beyond multiple listing service on the list price, transaction price, 
and time on the market. This presents the opportunity to unbundle real estate broker services; usually listing a home on a multiple listing service is tied to other brokerage services. The authors document that the average home sells for 5.9-7.7 percent less when a broker is present in the transaction. This provides some evidence for agency costs exceeding the advantages of a broker's expertise and knowledge of the market.

It is quite common in the real estate market that the same broker represents both parties in the transaction. On the one hand, such a setting imposes potential agency conflicts. On the other hand, this phenomenon may increase information efficiency and reduce transaction costs by more efficiently matching buyer and seller. Gardiner et al. (2007) analyze the implications of dual agency in the residential real estate brokerage market. The authors exploit the introduction of legislation in Hawaii in 1984 that requires brokers to disclose this fact to their clients. In the period before the law was introduced dual agency homes sold for 8 percent less than transactions where different brokers represented the buyer and seller. This decreased to 1.4 percent in the period after the legislation was passed. In addition, dual agency significantly reduces the time on the market over the entire sample period. The authors conclude that the results are in line with the belief that prior to the regulation dual agency could have induced agents to lower their effort levels by matching buyer and seller at a lower price.

More recently, Han and Hong (2015) assess the implications of dual agency in the residential real estate brokerage market for the U.S. between 2001 and 2009. The authors hypothesize that two types of dual agency may occur: the first type is matching-based and implies that the internal listing provides the highest utility to the buyer, the second type is strategically promoted and implies that financial rewards given to the agent lead to a suboptimal match. Nevertheless, the impact of strategic promotion should be smaller after the introduction of the Real Estate Business and Brokerage Act that requires brokers to inform their clients about dual agency. The estimates show that some 64 percent of dual agency transactions provide an efficient matching outcome, whereas the remainder of transactions are likely motivated by strategic promotion.

Although there is no research on scale effects and performance of advisors in commercial real estate transactions, some evidence exists regarding the importance of scale for investors. For Real Estate Investment Trusts (REITs), the extent to which economies of scale are present has been investigated in a number of studies. Early work in the field suggests that economies of scale for REITs exist (Bers and Springer, 1997; Capozza and Seguin, 1998). Ambrose et al. (2000) analyze the benefits of the consolidation in the REIT industry in the late nineties. Specifically, the authors investigate whether economies of scale from size, brand image, or geographic specialization can be observed in REITs. The authors document that REIT size is negatively related to growth in net operating income. Moreover, the authors do not find evidence that large REITs are better at controlling expenses. Similarly, brand imaging has no significant impact on net operating income growth. However, this does not imply anything about income levels; it might be that REITs with a strong brand image obtain higher income levels but do not display a difference in income growth. With respect to geographic specialization, the authors document that REITs that are concentrated in a particular market are not able to generate information efficiencies.

A follow-up study by Ambrose et al. (2005) argues that it is difficult to disentangle sizerelated advantages in a period of expansion and a strong REIT market. The authors address this limitation by studying a more recent time period, which contains a full market cycle. 
Furthermore, the authors employ a broad set of performance measures to test for economies of scale in REITs. In line with earlier findings, the authors document that small REITs have efficiency gains available in the area of growth, whereas large REITs are able to reduce costs and increase profit margins. The available measures allow the authors to test the implications of economies of scale in cost of capital as well. The findings display an inverse relationship between equity betas and firm size, suggesting that larger REITs are able to lower systematic risk. This effect is corroborated by the inverse relationship between size and the weighted average cost of capital.

Summarizing, the merger and acquisition literature suggests that the most prestigious investment banks execute the most complicated deals. Their effects on deal pricing and postdeal performance, however, is not consistent. For residential real estate brokerage, the literature shows that scale effects are visible in price and in time on the market, and that agency issues are salient in brokerage. This chapter investigates whether similar effects are present in commercial real estate transactions.

\subsection{Data and Descriptive Statistics}

\subsubsection{Data and Sources}

To investigate the impact of transaction service providers on the rental level and transaction price of office buildings, we retrieve commercial office market information from CoStar (CoStar Realty Information, Inc., 2015). CoStar maintains a comprehensive database with verified commercial assets in the U.S and the U.K., providing extensive geographic and historical coverage. Moreover, the information on the asset level is quite detailed, allowing us to elaborately control for building quality characteristics that may impact rents and transaction values, besides the effect of real estate transaction advisors.

We retrieve information on 164,323 commercial assets from CoStar: 94,580 rental observations and 69,743 transactions. ${ }^{3}$ However, to control for building quality characteristics in a complete manner, we can only include observations for which all building characteristics are available. We also exclude zip code clusters for which we have only one observation. Last, since we want to investigate the impact of both buying and selling real estate advisors on transaction values of office buildings we restrict the observations in the transaction sample to those for which both brokers are given. Hence, transactions in which no brokerage firm is involved, or in which only the selling or buying party employed a broker are excluded from the analysis. This reduces the sample to 65,653 rental and 51,615 sales transactions. The rental sample is a snapshot of existing rent contracts as of September 2015, while the transaction sample spans the time period from Q1 1990 to Q3 2015.

Figure 3.1 shows the geographical distribution for both samples by U.S. Core Based Statistical Area (CBSA). The rental sample includes 247 out of 929 CBSAs, the geographical coverage in the

\footnotetext{
${ }^{3}$ Comparing the average rent and occupancy rates observed in our sample to the statistics reported in CoStar's National Office Market Report shows that the average rent and occupancy rate in the U.S. office market are on average slightly higher (CoStar Group, Inc., 2016). This could indicate that the assets in our dataset are of somewhat lower quality as compared to the total market, and are therefore not completely representative of the U.S. office market.
} 
transaction sample is more than twice as high with a total of 513 CBSAs. Moreover, as indicated by the cut-off values for the quintiles, the rental sample is more concentrated as compared to the transaction sample. However, the geographic coverage is quite extensive for both the rental and transaction sample, and the maps in Figure 3.1 do not indicate a possible underrepresentation of important office markets in the U.S. As the maps show, most transaction occur in the large property markets on the East and West Coasts, but we also observe many transaction is such markets as Chicago, Denver, and Houston.

\section{Figure 3.1: Geographic Distribution of Observations}

Panel A: Ratio of Observations by CBSA in Quintiles - Rental Sample

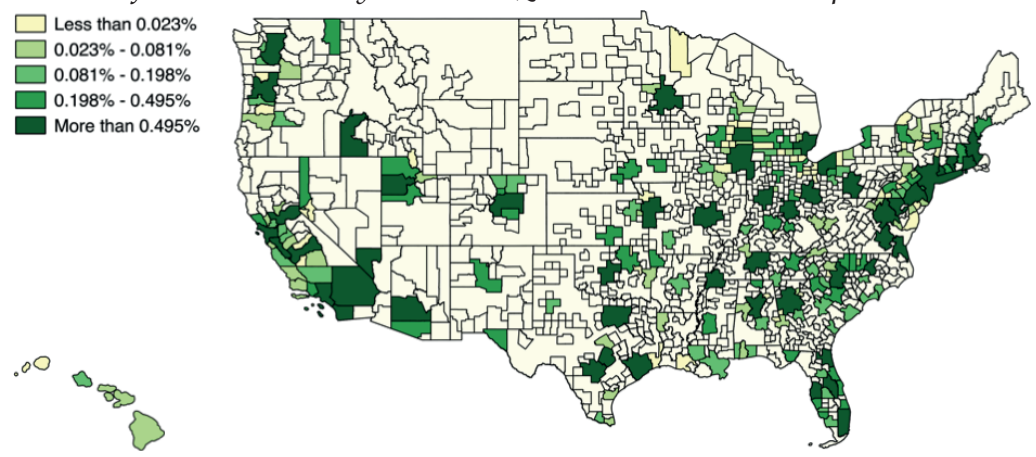

Panel B: Ratio of Observations by CBSA in Quintiles - Transaction Sample

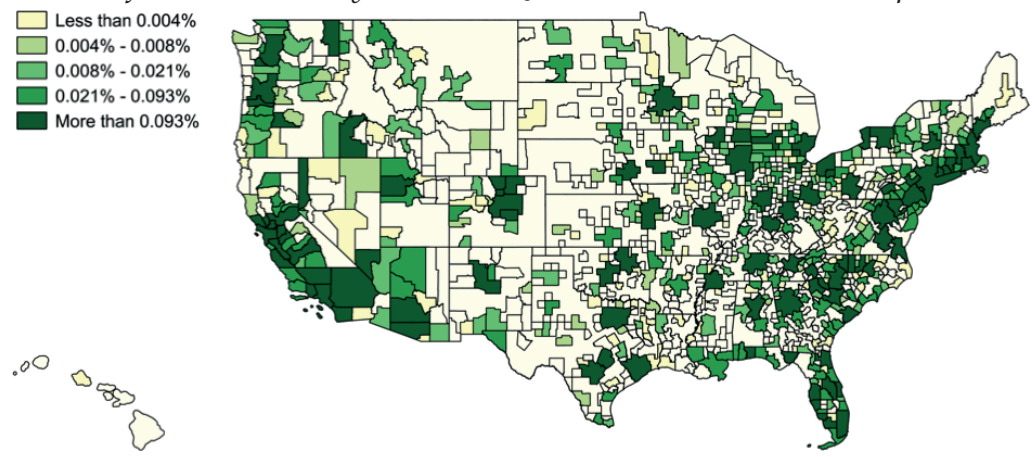

Notes: The share of observations in the rental and transaction sample is depicted by Core Based Statistical Area (CBSA) and based on the amount of observations in the CBSA relative to the total number of observations in the rental and transaction sample, respectively. Hawaii is enlarged for visibility. The state of Alaska is included in the estimation as well, for brevity it is excluded from the figure. The share of observations in Alaska and its corresponding CBSA, Anchorage, is 0.12 percent in the rental sample and zero percent in the transaction sample. This places Anchorage in the middle quintile for the rental sample.

\subsubsection{Descriptive Statistics}

Table 3.1 summarizes the average building characteristics for the assets included in the rental and transaction samples. Column (1) shows that the average building in the rental sample commands a rent of some 18 dollars per square foot, and an occupancy rate of about 80 percent. This results in an effective rent of almost 15 dollars per square foot. On average, the office 
buildings in the rental sample span just over 50,000 square feet, divided over three stories on a lot of a bit more than 2.4 acres.

Most buildings hold the quality designation "Class B." About one third of the sample is designated as "Class C," whereas only 12 percent of the buildings are "Class A" office space. The average building is more than 36 years old and 15 percent of the office buildings have been renovated. ${ }^{4}$ Besides these buildings' primary function as offices, they sometimes also have a secondary function. The most common one is "medical," which is the case for over 15 percent of buildings in the sample. The other secondary building functions are all very rare. Almost 17 percent of the office buildings in the rental sample have on-site amenities, and about 6 percent of buildings have access to public transport within one-quarter mile. ${ }^{5}$

In the transaction sample office buildings sell, on average, for about USD four million, with a price per square foot of some USD 152. The average number of transactions by year and zip code, as an indicator for market activity, is approximately three. Regarding building size, the average building measures some 31,000 square feet divided over more than two stories on a lot of two acres. Hence, the average building in the transaction sample is substantially smaller than the office buildings in the rental sample.

In terms of building quality we observe a slightly different distribution compared to the rental sample. Most sold buildings are designated as class B, and the fraction of class C buildings is substantially higher at more than 42 percent. The lower average building quality of the transaction sample is reflected in building age as well, with an average building age of almost 42 years. Similar to the rental sample, most office buildings have a medical function as secondary building type.

Since we aim to investigate the impact of scale advantages in the commercial real estate market, accurate information on the presence of real estate advisors and their market share in the sample is crucial. Therefore, we manually adjust the company names of the fifty largest real estate service providers, by number of observations, in both samples to reflect the correct firms. ${ }^{6}$ This exercise shows that the real estate advisory industry is not very concentrated. The fifty most active leasing agents in the rental sample represent 53 percent of the market, measured by value, this is only 35 percent for the most active fifty property managers. In all, the dataset contains some 20,000 and 14,000 unique leasing agencies and property management firms, respectively, further underscoring the relatively low concentration of the industry. The market position of the fifty most active transaction advisors is somewhat more dominant in the transaction sample. The fifty most active listing (buyer) brokers represent 76 (67) percent of the asset sales we observe, as measured by total asset value.

\footnotetext{
${ }^{4}$ Building age is defined relative to the year of construction as opposed to the year of renovation.

${ }^{5}$ One or more of the following amenities are included in the building: banking, convenience store, dry cleaner, exercise facilities, food court, food service, mail room, restaurant, retail shops, vending areas, fitness center.

${ }^{6}$ The cleaning process spans from adjusting small differences in company names to streamlining the names of subsidiaries to reflect the same advisor. This is especially relevant for the largest companies in the sample, since they operate many local offices or merged with different firms in the past.
} 
Table 3.1: Descriptive Statistics

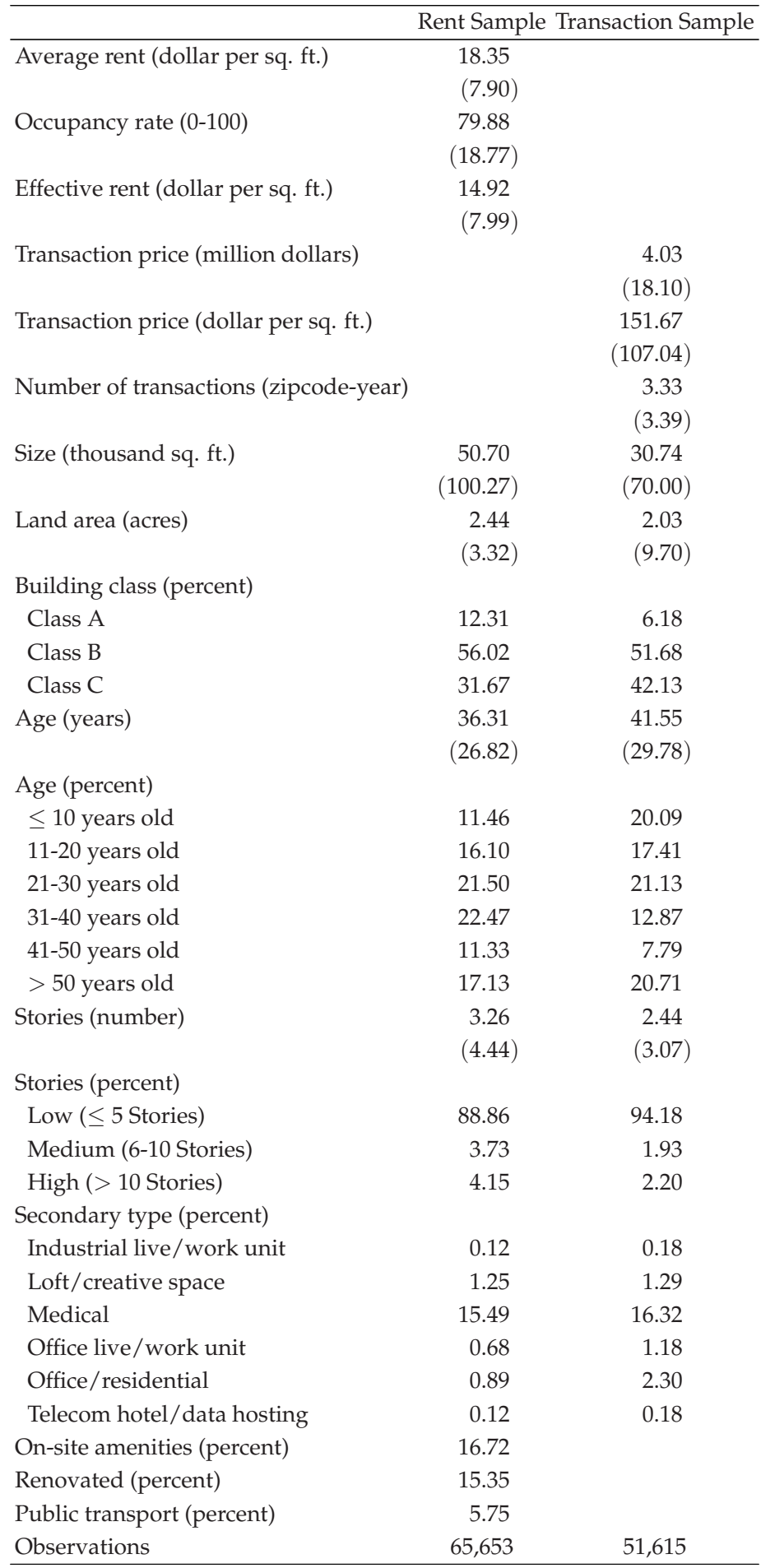

Notes: Standard deviations in parentheses. 
Figure 3.2 displays information regarding the presence of real estate transaction advisors by building quality class. ${ }^{7}$ Panel A shows that the fifty most active leasing agents and property managers in the rental sample tend to represent the highest quality space in the market. The effect is most pronounced for leasing agents, whereas the most active firms represent some 65 percent of all class A office buildings, they manage the leasing of 20 percent of all class $\mathrm{C}$ buildings. For the most active property management firms in the sample, these numbers are 44 percent for class A assets and just under 12 percent for class $\mathrm{C}$ assets. ${ }^{8}$

Panel B of Figure 3.2 presents the average share of the fifty most active transaction advisors in the transaction sample by market volume. Similar to what we observe in the rental sample, the most active real estate service providers are more likely to represent high quality space, but the differences across building classes are not as large as in the rental sample. The most active listing brokers represent more than 86 percent of class A transactions, whereas they are present in some 54 percent of class $C$ transactions only. The same holds for the advisors representing the buyer. In 74 percent of the class A transactions, the broker belongs to the fifty most active firms in the sample as compared to 49 percent of class $C$ transactions.

As discussed in the literature section, the mergers and acquisition studies show that the toptier firms tend to service the most complicated transactions. It is likely that this is also the case in commercial real estate brokerage. In terms of leasing contracts, there is not much variation in complexity, but in ownership transactions, we do observe such variation. We distinguish three proxies for deal complexity: building size, whether it is a portfolio transaction, and whether a transaction involves a significant number of conditions besides the price.

Table 3.2 provides information regarding the complexity proxies, and relates them to transaction advisor activity. We define three activity categories for real estate advisors based on the number of times they appear in our sample. Advisors that appear only once in the dataset are classified as "low activity," the remaining observations are divided in a "moderate activity" and "high activity" group based on the median number of times they appear in the dataset. Table 3.2 shows that more active brokers, both on the buy side and on the sell side, advise on the more complicated deals, no matter how we define deal complexity or broker activity. For example, the most active brokers both buy and sell assets more than twice as large as the least active ones, and are involved in portfolio transactions almost ten times as often.

\footnotetext{
${ }^{7}$ The calculation of the fractions presented in Figure 3.2 is based on the size of the market as measured by value. For the rental sample we calculate market size by multiplying the effective rent per square foot with building size. The fractions for the transaction sample are based on total transaction volume.

${ }^{8}$ Simple t-tests confirm that the average share of the fifty most active real estate service providers across building quality categories are significantly different from each other in both the rental and the transaction sample.
} 
Figure 3.2: Transaction Advisors by Building Class

Panel A: Top 50 Leasing Agents and Property Managers - Rental Sample

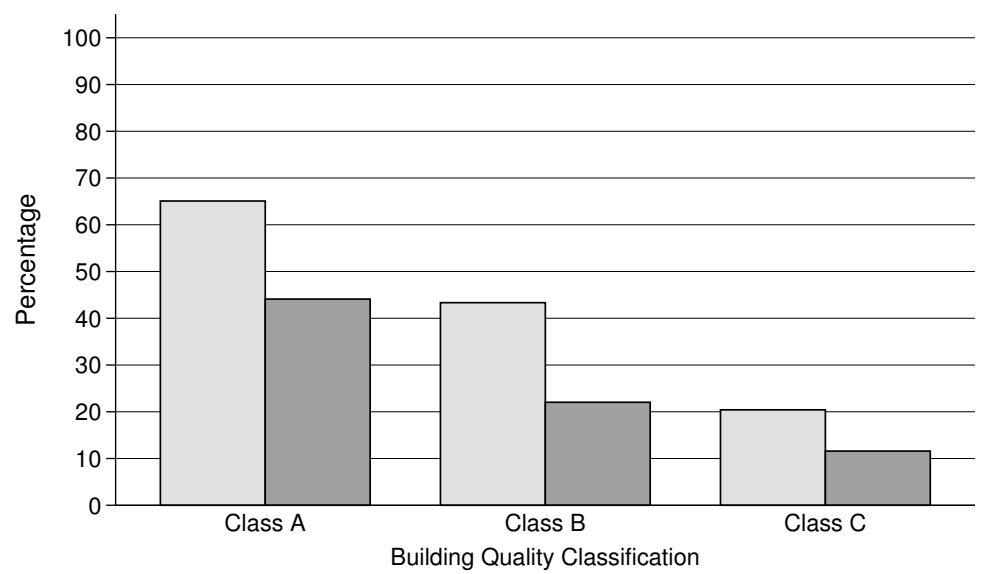

Leasing Agent Top 50

Property Manager Top 50

Panel B: Top 50 Buyer and Listing Brokers - Transaction Sample

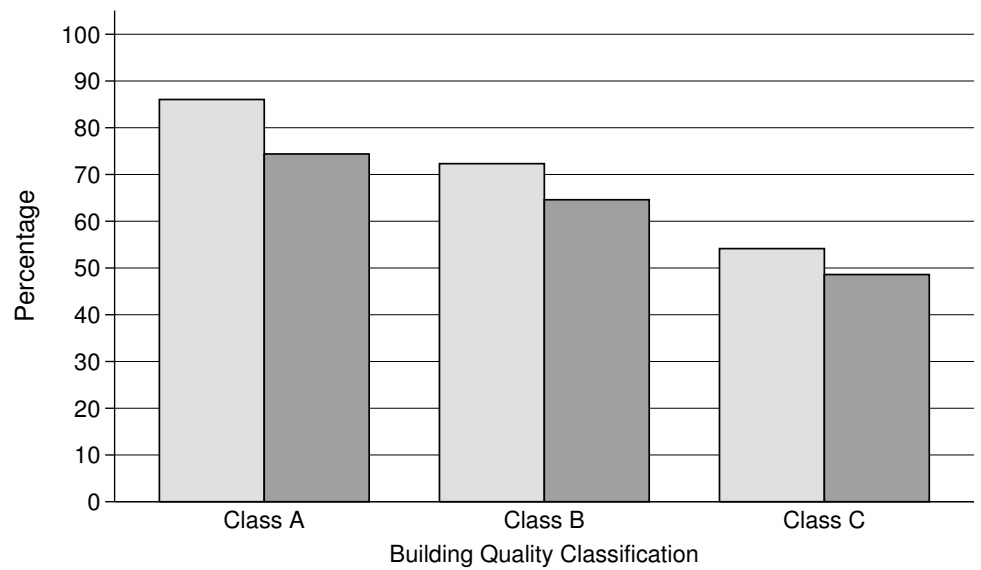

Listing Broker Top 50

Buyer Broker Top 50

Notes: The figure displays the share of the most active service providers in the rental and transaction sample by building quality class. The calculation of the fractions is based on the total effective rent and transaction value across categories, as measured by multiplying the effective rent or transaction price per square foot with building size. Panel A shows the fraction of the most active fifty leasing agents and property managers in the rental sample. Note that not all buildings in the rental sample have a property manager. The calculation of the fractions is adjusted to reflect only the portion of the sample that has a property manager. Panel B shows the fraction of the most active fifty buyer and listing brokers in the transaction sample. 
Table 3.2: Real Estate Broker Activity and Transaction Complexity

\begin{tabular}{|c|c|c|c|c|}
\hline & $\begin{array}{c}\text { Size } \\
\text { (thousand sq. } \mathrm{ft} .\end{array}$ & $\begin{array}{c}\text { Portfolio Sale } \\
\text { (percent) }\end{array}$ & $\begin{array}{l}\text { Sale Conditions } \\
\text { (percent) }\end{array}$ & $\begin{array}{c}\text { Observations } \\
\text { (number) }\end{array}$ \\
\hline \multicolumn{5}{|l|}{ Panel A: 50 Most Active Brokerage Firms } \\
\hline Listing broker - top 50 & $\begin{array}{c}41.23 \\
(88.84)\end{array}$ & 21.16 & 34.90 & 25,928 \\
\hline Listing broker - other & $\begin{array}{c}20.16 \\
(44.03)\end{array}$ & 8.70 & 27.79 & 25,687 \\
\hline Buyer broker - top 50 & $\begin{array}{c}41.69 \\
(90.32)\end{array}$ & 21.45 & 34.03 & 22,764 \\
\hline Buyer broker - other & $\begin{array}{c}22.10 \\
(49.11)\end{array}$ & 9.84 & 29.26 & 28,851 \\
\hline \multicolumn{5}{|c|}{ Panel B: Brokerage Firms by Activity Category } \\
\hline Listing broker - high activity & $\begin{array}{c}40.17 \\
(77.25)\end{array}$ & 21.56 & 34.94 & 22,562 \\
\hline Listing broker - moderate activity & $\begin{array}{c}25.51 \\
(70.42)\end{array}$ & 11.83 & 29.34 & 22,659 \\
\hline Listing broker - low activity & $\begin{array}{c}16.01 \\
(37.80)\end{array}$ & 2.77 & 25.88 & 6,394 \\
\hline Buyer broker - high activity & $\begin{array}{l}41.50 \\
(90.10)\end{array}$ & 21.45 & 33.79 & 21,278 \\
\hline Buyer broker - moderate activity & $\begin{array}{c}25.00 \\
(54.33)\end{array}$ & 13.79 & 30.20 & 21,284 \\
\hline Buyer broker - low activity & $\begin{array}{c}18.95 \\
(47.22)\end{array}$ & 2.46 & 28.38 & 9,053 \\
\hline
\end{tabular}

Notes: Standard deviations in parentheses. All variables in percent unless indicated otherwise. The real estate advisors in the transaction sample are divided in three activity categories based on the number of times they appear in the dataset. Real estate advisors that appear once in the sample are classified as "low activity." The remaining observations are classified as "moderate activity" and "high activity" based on the median number of times they appear in the sample. Listing brokers that appear between 2 and 210 times in the sample are categorized as "moderate activity", and listing brokers that appear more than 210 times are categorized as "high activity". Similarly, the cut-off value for buyer brokers in the transaction sample is 120 .

\subsection{Methodology}

We use the standard real estate valuation framework, the hedonic pricing model, to investigate the rent and price effects of transaction advisors in commercial real estate (Rosen, 1974). More specifically, we estimate a semi-log equation relating observable building characteristics to the rental level, occupancy rate, and transaction price per square foot:

$$
\log V_{i}=\alpha+\delta S_{i}+\tau S_{i} * D_{i}+\kappa D_{i}+\beta X_{i}+\gamma T+\epsilon_{i}
$$

where $V$ is the average rent, occupancy rate, effective rent, or transaction price per square foot of building $i$. The variable of interest in our model is $S$, which depicts different measures of the activity of the advisor servicing building $i$. We begin the analysis with the fifty most active real estate advisors by introducing an indicator variable for those firms. Then, we divide the 
real estate advisors into three groups. All transaction advisors that appear in the dataset only once are categorized as "low activity." The remaining observations are divided in a "moderate activity" and "high activity" group based on the number of times they appear in the dataset. $\delta$ is thus the marginal impact of the activity of an advisor on the economic value of an office building in the U.S. office market. $D$ is a vector of deal complexity measures. At a later stage we interact the deal complexity measures with the real estate transaction advisory firm servicing building $i$. Hence, $\kappa$ and $\tau$ are estimated coefficients on the deal complexity measures and the subsequent interaction effects with the real estate transaction advisor activity variables. $X$ is a vector of building characteristics (building class, size, age, etc.) and location (the five-digit zip code) of building $i$. In addition, the estimations of Equation (3.1) for the transaction sample control for macroeconomic effects by year-quarter fixed effects $T$. $\alpha, \beta$, and $\gamma$ are estimated coefficients for the control variables, $\epsilon$ is an heteroskedasticity-robust error term, clustered at the five-digit zip code level.

It is important to note that we only observe the presence of real estate transaction advisors and do not have any information about the quality of their services or the fee structures that different firms may employ. ${ }^{9}$ Therefore, it is possible that the premiums or discounts we find are simply a reflection of the costs associated with the services the transaction advisors provide. Moreover, we cannot control for the possibility that some real estate investors or buildings owners choose to deliberately hire the most active real estate transaction advisors to buy, lease, manage, and sell their assets. For example, it may be the case that asset owners strategically choose the most active real estate advisors for assets of lower quality, although the pattern observed in Figure 3.2 does not point in that direction.

\subsection{Results}

\subsubsection{Rental Sample}

Table 3.3 documents the results of Equation (3.1) for the rental sample. Columns (1) and (2) use the log of average rent as dependent variable, Columns (3) and (4) the occupancy rate of the office buildings in the rental sample, and Columns (5) and (6) show the results for the effective rent, as measured by multiplying the average rent for each building with the occupancy rate. The models in Table 3.3 explain between 9 and 64 percent of the variation in the dependent variables.

The results in Column (1) show the effects of the fifty most active leasing agencies (relative to boutique agencies) and the effects of the presence of property management firms and the fifty most active management firms (relative to no external property manager). ${ }^{10}$ We find that most active transaction advisors in the industry tend to obtain higher average rental levels compared to boutique advisors. The premium associated with "Top 50" leasing agents is 1.9 percent. Property managers in this category command a 2.4 percent premium, whereas the

\footnotetext{
${ }^{9}$ The observable characteristics of the real estate transaction advisors in the rental and transaction sample are limited to the company name and location, and the agent's name, and contact details.

${ }^{10}$ All buildings in the sample have a leasing agent, whereas only part of the buildings have an external property manager.
} 
presence of a property manager as such has an insignificant impact on the rental level. ${ }^{11}$ On average, the most active transaction advisors are able to extract between USD 17,700 and USD 21,400 more rent from an otherwise similar office building.

The control variables behave mostly according to expectations. Larger buildings command higher rental levels as indicated by the positive coefficient on building size. The significantly positive coefficient on the medium number of stories category corroborates this finding. Moreover, building quality has a large impact on the rent increment as displayed by the coefficients on building class. On average, office buildings designated as "Class A" rent for some 19 percent more than similar buildings with a "Class C" quality rating. The rent premium for "Class B"

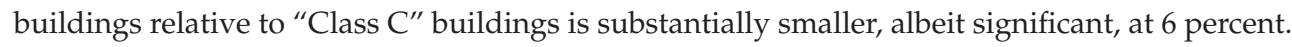
Building age, another proxy for building quality, shows that the newest buildings in the sample command a significant rent premium as compared to office buildings of more than fifty years old.

The results for the secondary building type categories show that office buildings with an additional "Medical" function, by far the largest category, command an 8 percent rent premium. Building with an "Industrial Live/Work Unit" or "Telecom Hotel/Data Hosting" function rent for less, but we observe very few of such buildings in the rental sample. Moreover, buildings that are renovated, have access to public transport within a quarter mile, and have on-site amenities command a rent premium compared to otherwise similar office buildings.

Column (2) of Table 3.3 divides the leasing agents and property managers in three different activity categories based on the number of times they appear in the sample. Transaction advisors that appear once in the dataset are categorized as "low activity." The remaining observations are divided into a "moderate activity" and "high activity" group based on the median number of occurrences in the dataset. ${ }^{12}$ Compared to low activity leasing agents, moderate and high activity leasing agents command a 1 and 2.5 percent higher rental level, respectively. The results for property management show that only the most active property managers are able to extract higher rental levels relative to buildings without a property manager, they obtain a 2.5 percent premium. The documented impact of the control variables in Column (2) is similar to the effects we find in the previous specification.

Columns (3) and (4) document the impact of leasing agents and property managers on the occupancy rate of office buildings. In contrast to the results documented for the average rent, leasing agents and property managers belonging to the fifty most active firms add no value in terms of higher occupancy rates. Property management companies in the top fifty obtain occupancy rates that are, on average, 1.3 percent lower as compared to the other property management firms. The results for the leasing agents point in the same direction, although the

\footnotetext{
${ }^{11}$ In an unreported specification we test the spearman rank correlation between the ranking of the fifty most active leasing agents and property managers based on the number of times they appear in the dataset, and their ranking based on the marginal effect on the average weighted rent we find - by using indicator variables for each of the fifty most active leasing agents and property managers in the dataset. The spearman rank correlation for leasing agents is negative whereas the spearman rank correlation for property managers is positive, although both correlation coefficients are insignificant.

${ }^{12}$ Leasing agents that appear between 2 and 21 times in the sample are classified as "moderate activity" and leasing agents that appear more than 21 times in the rental sample are classified as "high activity", based on the median number of occurrences. The cut-off value for medium and large property managers is 6 . The large difference between the cut-off values for leasing agents and property managers reiterates the higher concentration of leasing agents.
} 
coefficient is not significant. Dividing the leasing agents and property managers in three activity categories in column (4) supports this finding.

Regarding the control variables, the results show that newer buildings and buildings of higher quality have lower occupancy rates than older and less appealing office buildings in the rental sample. However, the explanatory power of the models for the occupancy rate is quite low, suggesting that factors beyond building characteristics, such as macro-economic conditions, are more important in determining the occupancy rate of a building.

Table 3.3: Rental Level, Occupancy Rate, and Real Estate Advisor Activity

\begin{tabular}{|c|c|c|c|c|c|c|}
\hline & \multicolumn{2}{|c|}{ Average Rent } & \multicolumn{2}{|c|}{ Occupancy Rate } & \multicolumn{2}{|c|}{ Effective Rent } \\
\hline & (1) & (2) & (3) & (4) & (5) & (6) \\
\hline Leasing agent - top 50 & $0.019^{* * *}$ & & -0.003 & & $0.013^{* * *}$ & \\
\hline (1=yes) & {$[0.003]$} & & {$[0.002]$} & & {$[0.005]$} & \\
\hline Property manager & 0.003 & & $0.007^{* * *}$ & & $0.015^{* * *}$ & \\
\hline (1=yes) & {$[0.003]$} & & {$[0.002]$} & & {$[0.004]$} & \\
\hline Property manager - top 50 & $0.024^{* * *}$ & & $-0.013^{* * *}$ & & 0.004 & \\
\hline (1=yes) & {$[0.005]$} & & {$[0.003]$} & & {$[0.007]$} & \\
\hline Leasing agent - moderate activity & & $0.010^{* * *}$ & & $0.012 * * *$ & & $0.026^{* * *}$ \\
\hline (1=yes) & & {$[0.003]$} & & {$[0.002]$} & & {$[0.005]$} \\
\hline Leasing agent - high activity & & $0.025^{* * *}$ & & 0.004 & & $0.027^{* * *}$ \\
\hline (1=yes) & & {$[0.003]$} & & {$[0.003]$} & & {$[0.005]$} \\
\hline Property manager - low activity & & -0.004 & & $0.010^{* * *}$ & & $0.012^{* *}$ \\
\hline (1=yes) & & {$[0.003]$} & & {$[0.002]$} & & {$[0.005]$} \\
\hline Property manager - moderate activity & & 0.006 & & 0.004 & & $0.014^{* *}$ \\
\hline$(1=$ yes $)$ & & {$[0.004]$} & & {$[0.002]$} & & {$[0.006]$} \\
\hline Property manager - high activity & & $0.025^{* * *}$ & & -0.002 & & $0.024^{* * *}$ \\
\hline (1=yes) & & {$[0.004]$} & & {$[0.003]$} & & {$[0.006]$} \\
\hline Log size & $0.029 * * *$ & $0.029^{* * *}$ & $0.034^{* * *}$ & $0.034^{* * *}$ & $0.083^{* * *}$ & $0.082^{* * *}$ \\
\hline (thousand sq. ft.) & {$[0.002]$} & {$[0.002]$} & {$[0.001]$} & {$[0.001]$} & {$[0.003]$} & {$[0.003]$} \\
\hline Log land area & 0.000 & 0.000 & $-0.004^{* * *}$ & $-0.005^{* * *}$ & $-0.007^{* * *}$ & $-0.008^{* * *}$ \\
\hline (acres) & {$[0.002]$} & {$[0.002]$} & {$[0.001]$} & {$[0.001]$} & {$[0.002]$} & {$[0.002]$} \\
\hline \multicolumn{7}{|l|}{ Building class ( $1=$ yes) } \\
\hline Class A & $\begin{array}{l}0.192^{* * *} \\
{[0.006]}\end{array}$ & $\begin{array}{l}0.191^{* * *} \\
{[0.006]}\end{array}$ & $\begin{array}{c}0.000 \\
{[0.004]}\end{array}$ & $\begin{array}{c}0.000 \\
{[0.004]}\end{array}$ & $\begin{array}{l}0.188^{* * *} \\
{[0.008]}\end{array}$ & $\begin{array}{l}0.187^{* * * *} \\
{[0.008]}\end{array}$ \\
\hline Class B & $\begin{array}{l}0.062^{* * *} \\
{[0.003]}\end{array}$ & $\begin{array}{l}0.061^{* * *} \\
{[0.003]}\end{array}$ & $\begin{array}{c}-0.006^{* * *} \\
{[0.002]}\end{array}$ & $\begin{array}{c}-0.006^{* * *} \\
{[0.002]}\end{array}$ & $\begin{array}{l}0.054^{* * *} \\
{[0.005]}\end{array}$ & $\begin{array}{l}0.053^{* * *} \\
{[0.005]}\end{array}$ \\
\hline \multicolumn{7}{|l|}{ Stories (1=yes) } \\
\hline Medium (6-10 stories) & $\begin{array}{l}0.026^{* * *} \\
{[0.006]}\end{array}$ & $\begin{array}{l}0.026^{* * *} \\
{[0.006]}\end{array}$ & $\begin{array}{r}-0.006 \\
{[0.004]}\end{array}$ & $\begin{array}{c}-0.006 \\
{[0.004]}\end{array}$ & $\begin{array}{l}0.018^{* *} \\
{[0.009]}\end{array}$ & $\begin{array}{l}0.018^{* *} \\
{[0.009]}\end{array}$ \\
\hline High ( $>10$ stories) & $\begin{array}{c}0.008 \\
{[0.009]}\end{array}$ & $\begin{array}{c}0.008 \\
{[0.009]}\end{array}$ & $\begin{array}{c}-0.024^{* * *} \\
{[0.005]}\end{array}$ & $\begin{array}{c}-0.024^{* * *} \\
{[0.005]}\end{array}$ & $\begin{array}{c}-0.028^{* *} \\
{[0.011]}\end{array}$ & $\begin{array}{c}-0.028^{* *} \\
{[0.011]}\end{array}$ \\
\hline \multicolumn{7}{|l|}{ Age (1=yes) } \\
\hline$\leq 10$ years old & $\begin{array}{l}0.151^{* * *} \\
{[0.006]}\end{array}$ & $\begin{array}{l}0.151^{* * *} \\
{[0.006]}\end{array}$ & $\begin{array}{c}-0.019^{* * *} \\
{[0.004]}\end{array}$ & $\begin{array}{c}-0.019^{* * *} \\
{[0.004]}\end{array}$ & $\begin{array}{l}0.125^{* * *} \\
{[0.009]}\end{array}$ & $\begin{array}{l}0.124^{* * *} \\
{[0.009]}\end{array}$ \\
\hline $11-20$ years old & $\begin{array}{l}0.086^{* * *} \\
{[0.006]}\end{array}$ & $\begin{array}{l}0.085^{* * *} \\
{[0.006]}\end{array}$ & $\begin{array}{c}0.000 \\
{[0.004]}\end{array}$ & $\begin{array}{c}-0.001 \\
{[0.004]}\end{array}$ & $\begin{array}{l}0.087^{* * *} \\
{[0.009]}\end{array}$ & $\begin{array}{l}0.085^{* * *} \\
{[0.008]}\end{array}$ \\
\hline 21-30 years old & $\begin{array}{l}0.029^{* * *} \\
{[0.005]}\end{array}$ & $\begin{array}{l}0.028^{* * *} \\
{[0.005]}\end{array}$ & $\begin{array}{c}-0.009^{* * *} \\
{[0.003]}\end{array}$ & $\begin{array}{c}-0.009^{* * *} \\
{[0.003]}\end{array}$ & $\begin{array}{l}0.019^{* *} \\
{[0.008]}\end{array}$ & $\begin{array}{l}0.017^{* *} \\
{[0.008]}\end{array}$ \\
\hline
\end{tabular}


Table 3.3 (continued from previous page)

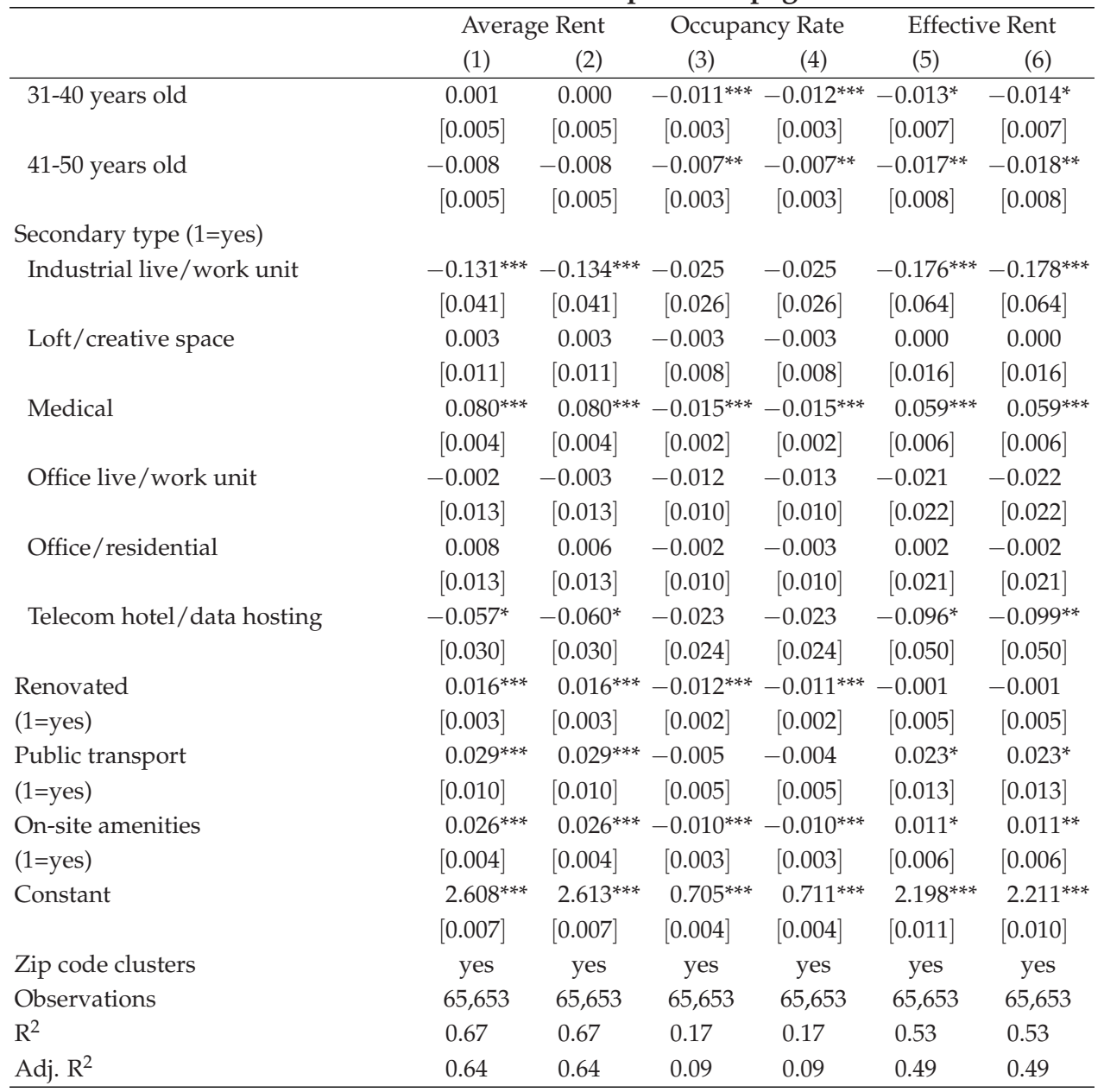

Notes: This table shows the results from a regression model using the logarithm of the average weighted rent, the occupancy rate, or the logarithm of effective rent per square foot as dependent variable. Heteroskedasticity-robust standard errors clustered on the five-digit zip code level in brackets. Significance at the $0.10,0.05$, and 0.01 level is denoted by ${ }^{*}{ }^{* *}$, and ${ }^{* * *}$, respectively.

The results for the effective rent in Columns (5) and (6) are in line with the effects we document for the specifications using the average rent as dependent variable. The fifty most active leasing agencies achieve a 1.3 percent higher cash flow compared to boutique leasing agencies. The results for property management firms indicate that the presence of a property manager yields a 1.3 percent higher effective rent, whereas companies belonging to the fifty most active property managers do not significantly outperform their competitors. Dividing the leasing agents and property managers in different activity categories in Column (6) shows that moderate and high activity leasing agencies command a 2.6 to 2.7 percent effective rent premium. The results for the property management companies indicate that the effective rent increment is increasing with company activity from 1.2 percent for the low activity property managers to 2.4 percent for the high activity property managers in the rental sample. This 
translates into an increase in annual cash flow between USD 18,200 and USD 20,400 for the most active property managers and leasing agents in the sample relative to boutique advisors, respectively. The results for the building characteristics are similar to the ones documented in column (1) and (2).

The findings in Table 3.3 show that the activity of the advisors has a positive and significant impact on the attained rental levels, whereas the impact on the occupancy rate is in the opposite direction. This suggest that the more active advisors in the industry are better at rental negotiations than boutique advisors and not necessarily obtain higher occupancy rates. However, we cannot dismiss the possibility that the observed rental premium for the most active real estate service companies is merely a reflection of higher fees associated with employing such companies.

\subsubsection{Transaction Sample}

Table 3.4 documents the results of estimating Equation (3.1) for the sales sample. For this sample we investigate the impact of listing and buyer brokers on the transaction price per square foot of office buildings. The specifications in Columns (1) and (2) of Table 3.4 are similar to the ones previously presented for the rental sample. Columns (3) and (4) present the result of a repeat sales estimation for a subset of 11,183 repeated transaction observations. This allows us to absorb all observable and unobservable building quality characteristics that may be correlated with the presence of a real estate transaction advisor. The models in Table 3.4 explain between 66 and 87 percent of the variation in the transaction price per square foot of the office buildings in the transaction sample.

Column (1) shows the results for the fifty most active buyer and seller brokerage firms, based on the number of times they appear in the sample. Contrary to what one may expect, the results indicate that the involvement of the most active transaction advisory firms in the industry leads to a 1.9 percent lower sales price and a 1.3 percent higher purchase prices. This remarkable finding translates into a discount of USD 76,600 in case the listing broker belongs to one of the fifty most active firms and a premium of USD 52,400 for the most active buyer brokers. ${ }^{13}$

Column (2) separates the brokerage firms into three activity categories in a similar way as for the rental sample. Brokerage firms that appear once in the dataset are designated as "low activity." The remaining observations are divided in a "moderate activity" and "high activity" group based on the median number of times they appear in the sample. ${ }^{14}$ Compared to the documented impact of the service providers that belong to the "Top 50" in column (1) the results are less clear-cut. Similar to the effect of the fifty most active listing brokers, we find a significant discount for the "high activity" listing brokers in the sample of 2 percent; the other categories are not significant.

The dataset also allows us to investigate the impact of real estate brokerage firms on the

\footnotetext{
${ }^{13}$ The effect is robust to different definitions of the most active brokerage firms. In alternative specifications we used the Top 10 up to the Top 40 as well. The effects are similar to the ones reported here.

${ }^{14}$ Listing brokers that appear between 2 and 210 times in the sample are classified as "moderate activity," and listing brokers that appear more than 210 times as "high activity," based on the median number of times they appear in the transaction sample. The cut-off value for buyer brokers in the transaction sample is 120 .
} 
transaction price per square foot for a subset of repeat sales observations. The benefit of repeat sales observations is that we absorb all observable and unobservable building quality characteristics, which may be correlated with advisor activity, in building fixed effects. ${ }^{15}$ In other words, the only varying observable building characteristic in the repeat sales sample is the activity of the advisor that is involved in the transaction. The results of the repeat sales analysis show effects of similar magnitude and direction, but contrary to the cross sectional hedonic analysis, the effects are not statistically significant.

Table 3.4: Transaction Price and Transaction Advisors Activity Cross Section Repeat Sales

(1)

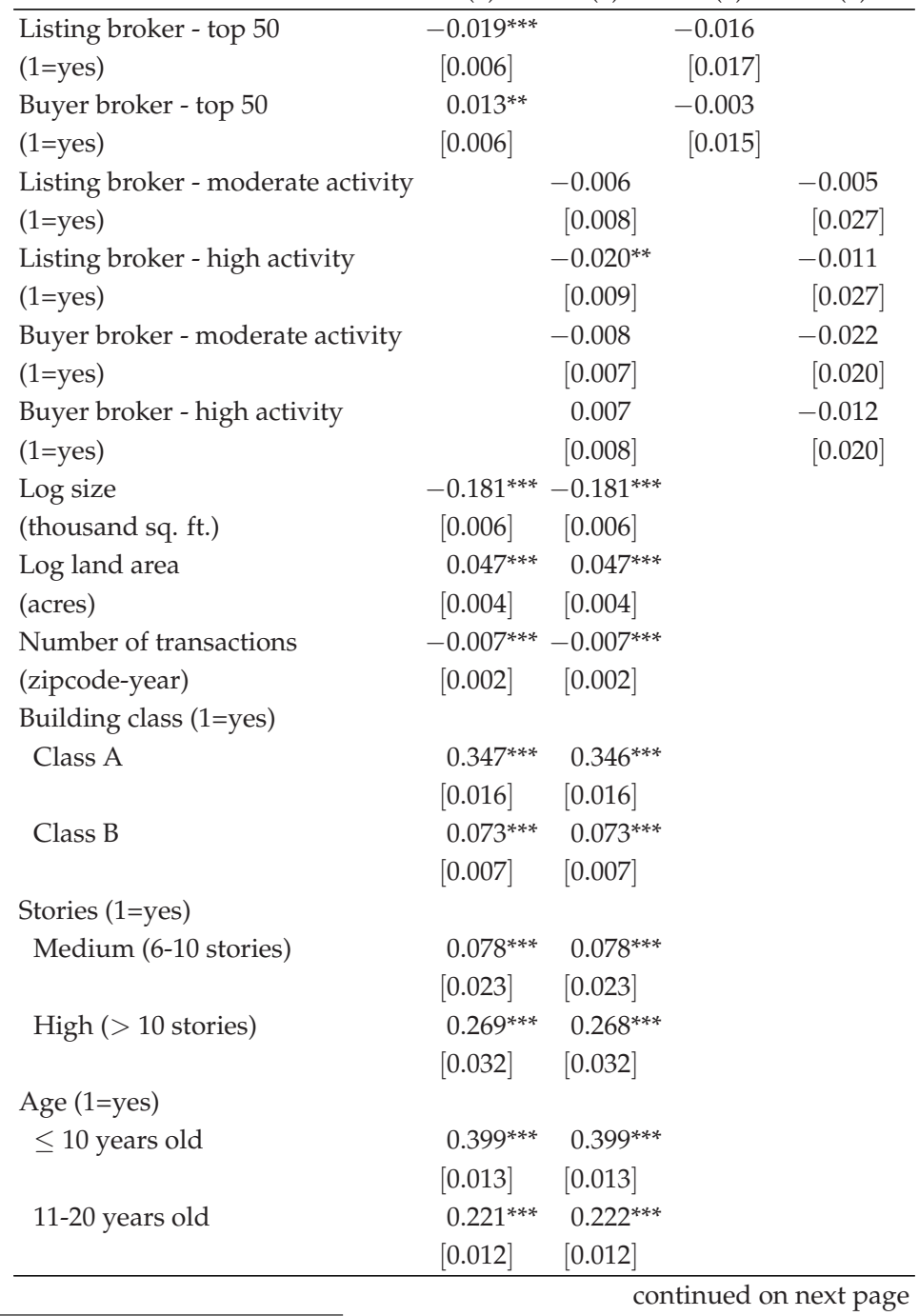

\footnotetext{
${ }^{15}$ To construct the repeat sales sample we select observations with the same location and building name. Moreover we ensure that the observable building characteristics across these sets of observations are identical. To mitigate the possibility that we observe transactions that are so-called "flips" we do not include transactions for the same building of which the time period between transactions is less than ninety days.
} 
Table 3.4 (continued from previous page)

\begin{tabular}{lcccc}
\hline & \multicolumn{2}{c}{ Cross Section } & \multicolumn{2}{c}{ Repeat Sales } \\
& $(1)$ & $(2)$ & $(3)$ & $(4)$ \\
\hline 21-30 years old & $0.077^{* * *}$ & $0.078^{* * *}$ & & \\
& {$[0.011]$} & {$[0.011]$} & & \\
31-40 years old & -0.014 & -0.014 & & \\
& {$[0.011]$} & {$[0.011]$} & & \\
41-50 years old & $-0.023^{*}$ & $-0.023^{*}$ & & \\
& {$[0.012]$} & {$[0.012]$} & & \\
Secondary type (1=yes) & & & & \\
Industrial live/work unit & -0.123 & -0.122 & & \\
& {$[0.075]$} & {$[0.075]$} & & \\
Loft/creative space & 0.009 & 0.009 & & \\
& {$[0.023]$} & {$[0.023]$} & & \\
Medical & $0.154^{* * *}$ & $0.154^{* * *}$ & & \\
& {$[0.008]$} & {$[0.008]$} & & \\
Office live/work unit & 0.007 & 0.007 & & \\
& {$[0.031]$} & {$[0.031]$} & & \\
Office/residential & $0.053^{* * *}$ & $0.052^{* * *}$ & & \\
& {$[0.020]$} & {$[0.020]$} & & \\
Telecom hotel/data hosting & -0.079 & -0.08 & & \\
Constant & {$[0.068]$} & {$[0.068]$} & & \\
& $4.542^{* * *}$ & $4.550^{* * *}$ & $4.626^{* * *}$ & $4.639^{* * *}$ \\
Building fixed effects & {$[0.087]$} & {$[0.087]$} & {$[0.205]$} & {$[0.206]$} \\
Zip code clusters & no & no & yes & yes \\
Year-quarter fixed effects & yes & yes & no & no \\
Observations & yes & yes & yes & yes \\
$\mathrm{R}^{2}$ & 51,615 & 51,615 & 11,183 & 11,183 \\
Adj. $\mathrm{R}^{2}$ & 0.66 & 0.66 & 0.87 & 0.87 \\
\hline & 0.62 & 0.62 & 0.76 & 0.76 \\
\hline
\end{tabular}

Notes:This table shows the results from a regression model using the logarithm of the transaction price per square foot as dependent variable. Heteroskedasticity-robust standard errors clustered on the five-digit zip code level in brackets. Significance at the $0.10,0.05$, and 0.01 level is denoted by *, **, and ***, respectively.

The results presented in Table 3.4 suggest that the most active transaction advisors in commercial real estate are not able to create value in terms of deal pricing even before real estate buyers and sellers have paid their fees. That begs the question why these buyers and sellers pay fees in the first place. The most active brokers are large precisely because they do the most deals, and rational investors would not retain them if they would not add value. We already observe in Table 3.2 that the most active brokers do the most complicated deals, and it is possible that this causes the effects we report in Table 3.4.

To investigate this, we interact deal complexity, using the same proxies as in Table 3.2, with the transaction price performance of buyer and seller transaction advisors. Table 3.5 provides the results of this analysis, which suggest that a large part of the price effects reported above are indeed due to deal complexity. Columns (1) and (2) examine the impact of transaction advisor activity in larger assets. The results indicate that buyer brokers belonging to the "Top 50" 
achieve a discount of 3.4 percent. However, this discount decreases with asset size as shown by the significantly positive interaction term in column (1). For the average building in our sample, this translates into a premium of 2.8 percent, an increase in transaction price of USD 113,000. We observe the same relationship for seller brokers. This implies that selling advisory firms sell smaller assets at a discount, and that the discount decreases with the size of the asset. At the point of means, this translates into a discount of 0.3 percent, a decrease in transaction price of some USD 12,000. Similar effects are observed in column (2) when real estate advisors are divided into three activity categories.

Columns (3) and (4) assess the complexity of the transaction as measured by portfolio sales. The baseline result indicates that portfolio sales are associated with a substantial discount ranging from 12 to 21 percent. Economically this effect is large: at the point of means, assets that are part of a portfolio transaction are sold for USD 484,000 to USD 838,000 less. As documented in column (4), employing a "moderate activity" buyer advisory firm significantly reduces the transaction price by an additional 10 percent, approximately USD 411,000 for the average building in the sample.

The results of using the presence of sale conditions as another proxy for deal complexity are presented in columns (5) and (6). The documented effects in column (5) suggest that, in addition to the negative association between sale conditions and the transaction price, seller and buyer advisors that belong to the "Top 50" are not able to alleviate this discount. On the contrary, the most active seller advisory firms sell assets at a larger discount relative to boutique advisors, whereas the most active buyer advisors pay a premium of 3.2 percent. The lack of significance of the interaction effects in column (6) can partially be explained by the limited variation in the presence of sale conditions across advisor activity categories as documented in Table 3.2.

Table 3.5: Transaction Complexity and Transaction Advisors

\begin{tabular}{|c|c|c|c|c|c|c|}
\hline & $(1)$ & (2) & (3) & $(4)$ & $(5)$ & $(6)$ \\
\hline Listing broker - top 50 & $-0.065^{* * *}$ & & $-0.018^{* * *}$ & & -0.009 & \\
\hline (1=yes) & {$[0.014]$} & & {$[0.006]$} & & {$[0.007]$} & \\
\hline Buyer broker - top 50 & $-0.034^{* *}$ & & $0.013^{* *}$ & & 0.002 & \\
\hline (1=yes) & {$[0.013]$} & & {$[0.006]$} & & {$[0.007]$} & \\
\hline Listing broker - moderate activity & & $-0.062^{* * *}$ & & 0.000 & & 0.001 \\
\hline (1=yes) & & {$[0.017]$} & & {$[0.008]$} & & {$[0.009]$} \\
\hline Listing broker - high activity & & $-0.086^{* * *}$ & & -0.012 & & -0.008 \\
\hline (1=yes) & & {$[0.019]$} & & {$[0.009]$} & & {$[0.010]$} \\
\hline Buyer broker - moderate activity & & -0.008 & & 0.009 & & -0.007 \\
\hline (1=yes) & & {$[0.016]$} & & [0.007] & & {$[0.008]$} \\
\hline Buyer broker - high activity & & $-0.058^{* * *}$ & & $0.019 * *$ & & 0.000 \\
\hline (1=yes) & & {$[0.017]$} & & {$[0.008]$} & & {$[0.009]$} \\
\hline Log size & $-0.198^{* * *}$ & $-0.219^{* * *}$ & $-0.185^{* * *}$ & $-0.185^{* * *}$ & $-0.178^{* * *}$ & $-0.178^{* * *}$ \\
\hline (thousand sq. ft.) & {$[0.006]$} & {$[0.009]$} & {$[0.005]$} & {$[0.005]$} & {$[0.005]$} & {$[0.005]$} \\
\hline Listing broker - top 50 * & $0.018^{* * *}$ & & & & & \\
\hline Log size & {$[0.005]$} & & & & & \\
\hline Buyer broker - top $50 *$ & $0.018^{* * *}$ & & & & & \\
\hline Log size & {$[0.005]$} & & & & & \\
\hline
\end{tabular}

continued on next page 
Table 3.5 (continued from previous page)

\begin{tabular}{|c|c|c|c|c|c|c|}
\hline & $(1)$ & $(2)$ & (3) & $(4)$ & (5) & (6) \\
\hline Listing broker - moderate activity * & & $0.028^{* * *}$ & & & & \\
\hline Log size & & {$[0.007]$} & & & & \\
\hline Listing broker - high activity* & & $0.031^{* * *}$ & & & & \\
\hline Log size & & {$[0.008]$} & & & & \\
\hline Buyer broker - moderate activity * & & 0.002 & & & & \\
\hline Log size & & {$[0.007]$} & & & & \\
\hline Buyer broker - high activity * & & $0.026^{* * *}$ & & & & \\
\hline Log size & & {$[0.007]$} & & & & \\
\hline Portfolio sale & & & $-0.208^{* * *}$ & $-0.120^{* *}$ & & \\
\hline (1-=yes) & & & {$[0.019]$} & {$[0.059]$} & & \\
\hline Listing broker - top $50 *$ & & & 0.039 & & & \\
\hline Portfolio sale & & & {$[0.025]$} & & & \\
\hline Buyer broker - top 50 * & & & 0.038 & & & \\
\hline Portfolio sale & & & {$[0.024]$} & & & \\
\hline Listing broker - moderate activity * & & & & 0.023 & & \\
\hline Portfolio sale & & & & {$[0.062]$} & & \\
\hline Listing broker - high activity * & & & & 0.042 & & \\
\hline Portfolio sale & & & & {$[0.062]$} & & \\
\hline Buyer broker - moderate activity * & & & & $-0.102^{*}$ & & \\
\hline Portfolio sale & & & & {$[0.058]$} & & \\
\hline Buyer broker - high activity * & & & & -0.060 & & \\
\hline Portfolio sale & & & & {$[0.058]$} & & \\
\hline Sale conditions & & & & & $-0.092^{* * *}$ & $-0.075^{* * *}$ \\
\hline (1=yes) & & & & & {$[0.008]$} & {$[0.017]$} \\
\hline Listing broker - top 50 * & & & & & $-0.024^{*}$ & \\
\hline Sale conditions & & & & & {$[0.013]$} & \\
\hline Buyer broker - top 50 * & & & & & $0.032^{* *}$ & \\
\hline Sale conditions & & & & & {$[0.013]$} & \\
\hline Listing broker - moderate activity * & & & & & & -0.023 \\
\hline Sale conditions & & & & & & {$[0.018]$} \\
\hline Listing broker - high activity * & & & & & & -0.028 \\
\hline Sale conditions & & & & & & {$[0.019]$} \\
\hline Buyer broker - moderate activity * & & & & & & -0.001 \\
\hline Sale conditions & & & & & & {$[0.016]$} \\
\hline Buyer broker - high activity * & & & & & & 0.020 \\
\hline Sale conditions & & & & & & {$[0.016]$} \\
\hline \multirow[t]{2}{*}{ Constant } & $4.586^{* * *}$ & $4.628^{* * *}$ & $4.572^{* * *}$ & $4.561^{* * *}$ & $4.535^{* * *}$ & $4.537^{* * *}$ \\
\hline & {$[0.088]$} & {$[0.089]$} & {$[0.089]$} & {$[0.089]$} & {$[0.086]$} & {$[0.086]$} \\
\hline Building characteristics & yes & yes & yes & yes & yes & yes \\
\hline Zip code clusters & yes & yes & yes & yes & yes & yes \\
\hline Year-quarter fixed effects & yes & yes & yes & yes & yes & yes \\
\hline Observations & 51,615 & 51,615 & 51,615 & 51,615 & 51,615 & 51,615 \\
\hline $\mathrm{R}^{2}$ & 0.66 & 0.66 & 0.66 & 0.66 & 0.66 & 0.66 \\
\hline Adj. $R^{2}$ & 0.62 & 0.62 & 0.63 & 0.62 & 0.62 & 0.62 \\
\hline
\end{tabular}

Notes: This table shows the results from a regression model using the logarithm of the transaction price per square foot as dependent variable. Heteroskedasticity-robust standard errors clustered on the five-digit zip code level in brackets. Significance at the $0.10,0.05$, and 0.01 level is denoted by ${ }^{*}, * *$, and ${ }^{* * *}$, respectively. 
Real estate transaction advisors cannot only add value in terms of price, but also in terms of liquidity. Real estate investors typically want to dispose of their assets quickly once they have decided to sell them. It may be possible that the counterintuitive results we reported in Table 3.4 are a price that investors pay - on top of the broker fee - for fast deal execution. For a large subset of property transactions $(34,630)$, we have the time it took to sell the asset, from first listing to deal execution. It is possible that this time on the market is related to broker activity. Specifically, it is likely that the most active brokers, who can employ a larger network, help sell properties faster than boutique advisors. Table 3.6 provides results of a regression in which time on the market is the dependent variable, with the same broker activity and control variables as before on the right hand side of the regression.

The results reported in Table 3.6 suggest that the most active real estate advisory firms are able to execute the deal more quickly as indicated by the negative coefficients on the "Top 50" variables. The most active listing and buying advisors reduce the time on the market by 9 and 17 days, respectively. Interestingly, the results in column (2) indicate that "moderate activity" listing brokers have a significant positive impact on the time on the market. This effect can in part be explained by the trend we observe in time on the market across advisor activity categories. While time on the market is linearly decreasing with advisor activity for the buyer brokers, this is not the case for the listing brokers. More specifically, time on the market is significantly lower for the most active listing advisors relative to boutique advisors, whereas time on the market is larger for the "moderate activity" listing broker category relative to boutique advisors.

Table 3.6: Time on the Market and Advisor Activity

\begin{tabular}{lcc}
\hline & $(1)$ & $(2)$ \\
\hline Listing broker - top 50 & $-8.927^{*}$ & \\
$(1=$ yes) & {$[5.330]$} & \\
Buyer broker - top 50 & $-16.859^{* * *}$ & \\
(1=yes) & {$[4.930]$} & \\
Listing broker - moderate activity & & $15.798^{* *}$ \\
(1=yes) & {$[6.982]$} \\
Listing broker - high activity & & 1.203 \\
(1=yes) & {$[7.536]$} \\
Buyer broker - moderate activity & & $-18.629^{* * *}$ \\
(1=yes) & & {$[6.024]$} \\
Buyer broker - high activity & & $-27.734^{* * *}$ \\
(1=yes) & {$[6.648]$} \\
Log size & $14.779^{* * *}$ & $14.797^{* * *}$ \\
(thousand sq. ft.) & {$[3.287]$} & {$[3.284]$} \\
Log land area & $4.886^{*}$ & $4.941^{*}$ \\
(acres) & {$[2.927]$} & {$[2.926]$} \\
Number of transactions & 0.936 & 0.954 \\
(zipcode-year) & {$[1.939]$} & {$[1.938]$} \\
Building class (1=yes) & & \\
Class A & $-40.177^{* * *}$ & $-40.556^{* *}$ \\
& {$[17.614]$} & {$[17.637]$} \\
Class B & $14.832^{* * *}$ & $14.930^{* * *}$ \\
& {$[5.157]$} & {$[5.159]$} \\
\hline & continued on next page \\
& &
\end{tabular}


Table 3.6 (continued from previous page)

\begin{tabular}{|c|c|c|}
\hline & $(1)$ & (2) \\
\hline \multicolumn{3}{|l|}{ Number of stories (1=yes) } \\
\hline Medium (6-10 stories) & $\begin{array}{c}-56.864^{* * *} \\
{[15.410]}\end{array}$ & $\begin{array}{c}-57.084^{* * *} \\
{[15.422]}\end{array}$ \\
\hline High ( $>10$ stories) & $\begin{array}{c}-73.567^{* * *} \\
{[23.720]}\end{array}$ & $\begin{array}{c}-75.200^{* * *} \\
{[23.705]}\end{array}$ \\
\hline \multicolumn{3}{|l|}{ Age (1=yes) } \\
\hline$\leq 11$ years old & $\begin{array}{c}23.633^{* *} \\
{[10.265]}\end{array}$ & $\begin{array}{l}23.712^{* *} \\
{[10.265]}\end{array}$ \\
\hline $11-20$ years old & $\begin{array}{c}-24.200^{* * *} \\
{[8.222]}\end{array}$ & $\begin{array}{c}-23.941^{* * *} \\
{[8.226]}\end{array}$ \\
\hline 21-30 years old & $\begin{array}{c}-9.088 \\
{[7.491]}\end{array}$ & $\begin{array}{c}-8.822 \\
{[7.500]}\end{array}$ \\
\hline $31-40$ years old & $\begin{array}{c}4.245 \\
{[7.879]}\end{array}$ & $\begin{array}{c}4.763 \\
{[7.879]}\end{array}$ \\
\hline $41-50$ years old & $\begin{array}{l}10.890 \\
{[8.438]}\end{array}$ & $\begin{array}{l}10.812 \\
{[8.445]}\end{array}$ \\
\hline \multicolumn{3}{|l|}{ Secondary type (1=yes) } \\
\hline Industrial live/work unit & $\begin{array}{r}-52.400 \\
{[54.855]}\end{array}$ & $\begin{array}{r}-51.767 \\
{[54.702]}\end{array}$ \\
\hline Loft/creative space & $\begin{array}{r}-31.126^{*} \\
{[17.902]}\end{array}$ & $\begin{array}{r}-30.365^{*} \\
{[17.849]}\end{array}$ \\
\hline Medical & $\begin{array}{c}-23.451 \\
{[18.206]}\end{array}$ & $\begin{array}{r}-24.046 \\
{[18.139]}\end{array}$ \\
\hline Office live/work unit & $\begin{array}{c}5.237 \\
{[7.184]}\end{array}$ & $\begin{array}{c}5.265 \\
{[7.183]}\end{array}$ \\
\hline Office/residential & $\begin{array}{c}-39.441^{* * *} \\
{[12.338]}\end{array}$ & $\begin{array}{c}-39.847^{* * *} \\
{[12.352]}\end{array}$ \\
\hline Telecom hotel/data hosting & $\begin{array}{r}-10.133 \\
{[54.212]}\end{array}$ & $\begin{array}{c}-11.191 \\
{[54.327]}\end{array}$ \\
\hline Constant & $\begin{array}{l}364.478^{* * *} \\
{[19.839]}\end{array}$ & $\begin{array}{l}363.652^{* * *} \\
{[20.408]}\end{array}$ \\
\hline Zip code clusters & yes & yes \\
\hline Year-quarter fixed effects & yes & yes \\
\hline Observations & 34,630 & 34,630 \\
\hline $\mathrm{R}^{2}$ & 0.30 & 0.30 \\
\hline Adj. $R^{2}$ & 0.18 & 0.18 \\
\hline
\end{tabular}

Notes: This table shows the results from a regression model using the time on the market (in days) as dependent variable. Heteroskedasticity-robust standard errors clustered on the five-digit zip code level in brackets. Significance at the $0.10,0.05$, and 0.01 level is denoted by ${ }^{*}, * *$, and ${ }^{* * *}$, respectively. 


\subsection{Conclusion}

Despite their ubiquity in the commercial real estate market, the added value of transaction advisory firms has hardly been investigated in the academic literature. Pension funds and other commercial real estate investors almost always retain the services of buying brokers, leasing agents, property managers and listing agents to help them buy, manage, and sell their assets. We employ large datasets of 65,653 U.S. office rental contracts and 51,615 office transactions to investigate this issue, specifically investigating whether more active transaction advisors add more value.

We observe a clear pattern in the presence of real estate advisors, the most active advisors are involved in assets of higher quality, and real estate investors employ their services in the most complicated transactions. They are mostly involved in the buying and selling of the largest buildings and in portfolio deals with many additional conditions.

In the rental market, we find that more active advisors help their clients obtain higher rents for their assets, after controlling for a broad set of building and location quality characteristics. The rental premium is about 2 percent. When it comes to ownership transactions, however, our results are more surprising: we find that the most active listing brokers sell buildings for 1.9 percent less than boutique advisors, and that clients of the most active buying brokers pay 1.3 percent more for their asset purchases. This result raises the question why so many investors choose to retain a large brokerage house.

To investigate that question, we analyze liquidity effects by analyzing how long it takes to sell assets. This analysis shows that asset sales supported by the most active brokers take considerably less time as compared to those advised by their boutique advisors. On average, "high activity" brokers are able to execute the transaction 9 to 17 days faster than boutique advisors. Nevertheless, this only holds for the most active real estate advisory firms in the industry.

The complexity of the deal also influences the outcome of a transaction, and more active brokerage houses are involved in such transactions more often. The most active real estate advisors are able to outperform their boutique advisors when buying or selling large assets. We document that in case the transaction is a portfolio sale or the transaction involves additional sale conditions, more active advisors do not achieve better deals for their clients.

This chapter shows that more active transaction advisors seem to add value in the U.S. commercial real estate industry, although that value-added is not always visible in asset prices. Overall, the impact of the activity of real estate transaction advisors is most profound in rent levels and the time it takes to execute an asset sale. 


\section{Chapter 4}

\section{On the Value of Environmental Certification in the Commercial Real Estate Market ${ }^{*}$}

\subsection{Introduction}

It is now common knowledge that the commercial real estate sector is related to many environmental externalities. For example, commercial real estate consumed 19 percent of total energy demand in 2014. ${ }^{2}$ Awareness of the importance of building level energy efficiency has been created through, for example, federal programs such as EPA's Energy Star, whereas other voluntary certification programs place further importance on the fact that the commercial real estate sector is a major consumer of water and other natural resources, while also producing significant landfill waste and greenhouse gas emissions. The significant environmental impacts of the built environment have captured the attention of regulators, the public, corporate occupiers, and investors, who are increasingly demanding more transparency in the environmental performance of buildings, for example through certification.

The effects of certification and quality disclosure as tools for information provision have been documented quite extensively. ${ }^{3}$ Jin and Leslie (2003) investigate the impact of requiring restaurants to display a hygiene quality grade card in their window. The authors employ a panel dataset from Los Angeles County to estimate the impacts of this requirement. The findings show that the overall hygiene score of restaurants increases after the legislation is introduced and that consumers are sensitive to changes in hygiene quality. Importantly, the improvement in hygiene quality led to a reduction in foodborne illness in the region. Moreover, the authors conclude that ultimately the differences between voluntary and mandatory disclosure are significant, although small in magnitude.

\footnotetext{
${ }^{*}$ This chapter is co-authored with Nils Kok (Maastricht University).

${ }^{2}$ Statistics from the U.S. Energy Information Administration indicate that the commercial real estate sector consumed 19 percent and the residential sector 22 percent of total energy demand in 2014. Moreover, commercial buildings consumed 36 percent of total electricity demand. This translates into the emission of 981 million metric tons of carbon dioxide from energy consumption in the commercial building stock.

${ }^{3}$ Dranove and Jin (2010) provide an overview of studies that assess the impact of quality disclosure and certification in various industries.
} 
Analogous to the hygiene quality grade cards in Los Angeles' restaurants, Bollinger et al. (2011) examine the impact of mandatory calorie postings in chain restaurants. The authors document that the average calories per transaction decrease by six percent after introducing the law in NYC in April 2008. The effect is almost entirely related to food purchases as compared to beverage purchases. Moreover, the effect is persistent throughout the period of observation (from January 2008 to March 2009). The authors conclude that the mandatory calorie postings do not have a significant impact on revenue, although revenue increases by three percent in case there is nearby competition.

For the automotive industry, Sexton and Sexton (2014) document that consumers are willing to pay up to several thousand dollars more for vehicles that are perceived as environmentally friendly. The authors employ zip-code-level data for the states of Colorado and Washington on vehicle purchases to examine the extent to which consumers are willing to pay a premium for a Toyota Prius. The authors conclude that such forms of conspicuous conservation may improve social welfare by moving towards optimal levels of environmental protection.

For the commercial real estate industry, building certificates concerning the energy or environmental performance aim to reduce information asymmetry by providing prospective buyers and tenants with a credible signal regarding the quantitative sustainability performance of a building. Given that these assets are long lived, such information may be valuable. The certification efforts are comparable to that of providing an energy label for home appliances such as an Energy Star label in the U.S. or an Energy Performance Certificate in Europe. Such labels providing information on the underlying characteristics of a product were first introduced in the market for consumer appliances and goods. However, whereas purchasing home appliances or consuming a meal at a restaurant are relatively short-term investments, investments in the built environment most often have a longer duration and larger scale such that small effects may have large consequences.

There is a growing body of academic evidence that information disclosure through environmental certification programs such as Energy Star and LEED have positive implications for the financial performance of commercial assets. ${ }^{4}$ Palmer and Walls (2014) document that requirements of energy performance disclosure as part of city and statewide legislation are increasing. This implies that the adoption and disclosure of "green" building certificates is slowly transforming from voluntary to mandatory. Moreover, since corporate users increasingly place importance on occupying environmentally certified space, it is necessary for the real estate sector, including asset owners and investors, to better understand the implications of environmentally certified space in the market.

Prior research has evaluated the financial performance of environmentally certified buildings when this market was still emerging. The rapid increase in the adoption of environmental building certification raises the question whether such performance differences are still present in a commercial real estate market where "green" building is becoming the new normal. Hence, in light of the recent growth in environmental building certification and a maturing market for "green" buildings, the financial performance of certified buildings over time may be dynamic. In addition, it is important to understand which underlying building or certification characteristics determine the financial performance of environmentally certified buildings.

\footnotetext{
${ }^{4}$ See for example, Chegut et al. (2014); Eichholtz et al. (2010, 2013); Fuerst and McAllister (2011); Wiley et al. (2010).
} 
This chapter measures the adoption and investigates the financial implications of environmental certification in the real estate market. First, we explore the diffusion of environmental certification in the commercial real estate sector - over space and time. We document that in the 30 largest MSAs, the average share of environmentally certified space has increased from a mere 5.7 percent in 2005 to 38.7 percent at the end of 2014. We then construct rent indices for environmentally certified and non-certified buildings, using a panel dataset of 25,690 U.S. commercial office buildings, to track the quarterly rent growth and volatility of environmentally certified and non-certified buildings over the Q1 2004 to Q3 2013 period. Based on the estimated repeated rent indices, we document that there is no relationship between rent growth and environmental certification. There are a number of ways to explain this finding. First, once a rent premium for environmentally certified building is established they follow the commercial real estate market in terms of rent growth. Second, the number of environmentally certified buildings for which we are able to track the quarterly rental growth is too small to make conclusive inferences about dynamic performance differences.

Third, employing a cross-section of 39,236 U.S. office buildings — assessed in Q3 2013 - we estimate a performance attribution model to examine the impact of the underlying environmental characteristics on the financial performance of certified buildings. The findings corroborate earlier studies, showing that certified buildings achieve higher rental rates and transaction prices. We document that there is significant heterogeneity in the marginal effect of environmental building certification: local climate conditions, local electricity prices and certification levels and scores influence the marginal rents and transaction prices.

In the next section, we first discuss the concept of environmental certification in the built environment, and document the diffusion of environmentally certified buildings in the commercial real estate market over time. We then present the rent indices for environmentally certified and non-certified assets and discuss the data and method employed to estimate the rent indices. The subsequent section discusses the data, method and results of the performance attribution analysis. The chapter ends with a conclusion and discussion of the implications.

\subsection{Environmental Certification in Commercial Real Estate}

There are two main programs that currently assess commercial building energy and environmental performance in the U.S.: The Environmental Protection Agency's (EPA) Energy Star and the United States Green Building Council's (USGBC) LEED certification program. While both programs are traditionally based on voluntary adoption and disclosure, environmental building certification has over the past years become an important indicator in some of the major U.S. commercial real estate markets, leading city governments to mandate, and investors and tenants to ask for such labels in leasing and financing decisions.

The USGBC, a private non-profit organization, developed the Leadership in Energy and Environmental Design (LEED) rating system. ${ }^{5}$ This rating system, first implemented in 1999, provides third-party verification regarding the environmental attributes of a building. As suggested by its name, LEED is traditionally implemented in the design phase of the construction

\footnotetext{
${ }^{5}$ More information on the rating system is available at www .usgbc.org/leed.
} 
or renovation of an asset. Different LEED programs verify the environmental attributes of buildings. LEED for New Construction (LEED NC) and Core and Shell (LEED CS) are applied to newly constructed buildings, whereas the programs LEED for Existing Buildings (LEED EB) and Commercial Interiors (LEED CI) are used for existing buildings. Credits are awarded in six main categories to evaluate the environmental performance of a building: the sustainability of the site, water efficiency, energy and atmosphere, materials and resources, indoor environmental quality and innovative design are addressed in these categories. The combined score in each of these categories is translated into a specific rating level: Certified, Silver, Gold or Platinum.

The Energy Star program is another major program that attests to the environmental outcomes of a building, although it focuses on energy efficiency alone. The Energy Star program started out as a voluntary program to promote the energy efficiency of consumer products and home appliances. The program includes real estate since 1995, and certification of buildings commenced in 1999. The Energy Star program evaluates the amount of source energy, the amount of energy used in a building as certified by a professional engineer. To qualify for an Energy Star label, a building's standardized energy consumption must be in the top 25 percent of all buildings relative to a peer set of buildings receiving a rating from 0 to 100 . Buildings with a rating of 75 or higher receive an Energy Star label.

Currently, a total of 6,058 office buildings, representing 7,239 certificates and some 1.4 billion square feet of office space have received some form of LEED certification. ${ }^{6}$ Additionally, 9,671 office buildings, representing more than 2.1 billion square feet of office space, have been awarded an Energy Star label, denoting the top energy performers among their peer set. ${ }^{7}$

We map the diffusion of Energy Star labels and LEED certifications by identifying the environmentally certified assets in each of the 30 largest commercial office markets in the U.S. Combining the information on the number and square footage of environmentally certified buildings with market information provided by CBRE, a real estate services firm, allows us to create a relative measure of the adoption of environmentally certified buildings over time. The market information received from CBRE denotes the amount of competitive space in each market. This implies that all owner-occupied and government buildings are excluded from this measure. In addition, we apply a two and five-year label "depreciation" window for Energy Star and LEED, respectively; in case an asset does not re-certify after two or five years we no longer include the asset in the measure of environmentally certified buildings.

The results of this simple analysis show that the share of buildings certified under the Energy Star or LEED program in the 30 largest office markets in the U.S., representing more than two-thirds of the total U.S. office market, has increased rapidly over the last decade. Panel A of Figure 4.1 shows the average diffusion of environmental certification in these 30 markets over the past ten years. Compared to 1.5 percent at the end of 2005, the adoption numbers show that at the end of 2014, some 13.1 percent of the commercial building stock obtained an Energy Star label or LEED certification. Measured by size, the amount of certified commercial space has increased from 5.7 percent in 2005 to 38.7 percent at the end of 2014. Moreover, the difference in diffusion when measuring the adoption rate in number of buildings or in terms of square

\footnotetext{
${ }^{6}$ Retrieved on February 22, 2016 from: www . gbig. org, based on all LEED certified buildings in the U.S. Office building collection.

${ }^{7}$ Retrieved on February 22, 2016 from: www.energystar.gov, based on a selection of facility types which include, Bank Branch, Financial Office, Medical Office and Office.
} 
footage shows that large buildings are more likely to get certified first.

Panels B and C of Figure 4.1 show the adoption rate of the Energy Star label and LEED certification, respectively. The diffusion of the Energy Star label, as shown in Panel B, started a few years earlier as compared to the LEED certification program and is slowing down in the most recent years. The diffusion of LEED, however, increased rapidly from 2009 onwards and only recently shows signs of stabilization. The difference in adoption rates between the two certification programs might stem from differences in the difficulty of obtaining the certification or the costs associated with applying for the certification.

We document large geographic variation in the adoption of Energy Star and LEED certification, which is largely determined by regulation and tenant demand. The leading markets in terms of green building adoption by percentage of square footage are Minneapolis and San Francisco, with 70.4 percent and 70.0 percent certified respectively, whereas Kansas City and Stamford have a coverage of 10.9 percent and 12.9 percent of their commercial office market.

Overall, the adoption curves show that environmentally certified buildings now represent a major share of the U.S. commercial office market, with the adoption of environmentally certified space in some markets perhaps even approaching a saturation point. One could argue that "green" building is becoming the new normal in some cities.

\subsection{Repeated Rent Indices}

\subsubsection{Empirical Framework}

To understand the temporal financial performance implications of environmental building certification, we construct a series of rent indices. We apply a repeated measure regression methodology, similar to the method employed by Ambrose et al. (2015); An and Pivo (2015); Eichholtz et al. (2012b). The repeated measure regression method incorporates all buildings that have rent data available for at least two quarters during the sample period, to calculate the percentage change in the variable of interest. This variable is either the total net asking rent or the effective rent, where the effective rent is calculated by multiplying the total net asking rent with the occupancy rate for each observation. ${ }^{8}$ Since the actual underlying cash flow of the building is of primary interest, the effective rent is considered to be the most important measure for a building owner. The index is based on the actual change in asking or effective rent:

$$
r_{i, t, s}=\ln \left(\frac{R_{i, t}^{s q f t}}{R_{i, t-s}^{s q f t}}\right), i=1, \ldots, N ; t=s, \ldots, T
$$

where $r$ is the total rental growth of building $i$ during periods $(t-s, t]$. This specification ensures that the change in rent is attributed to all relevant quarters. If, for example, we observe the rent for Q2 2006 and Q1 2007, the change in rent over this period is attributed to Q3 2006, Q4

\footnotetext{
${ }^{8}$ The total net asking rent is a measure of the rent across the entire asset, we do not observe information on individual leases.
} 
Figure 4.1: The Adoption of Environmental Building Certification Panel A: Energy Star and Leed Adoption

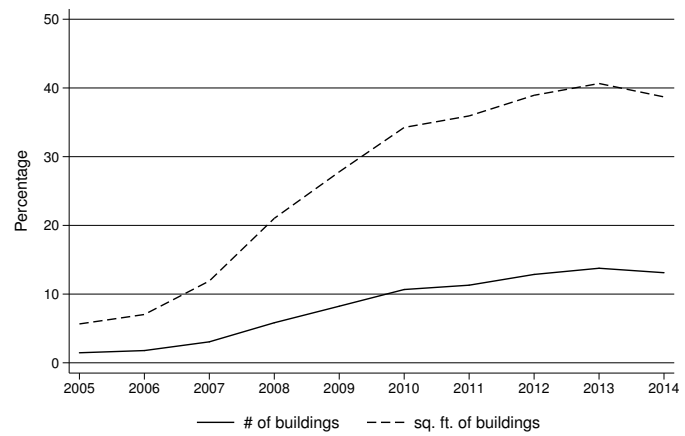

Panel B: Energy Star Adoption

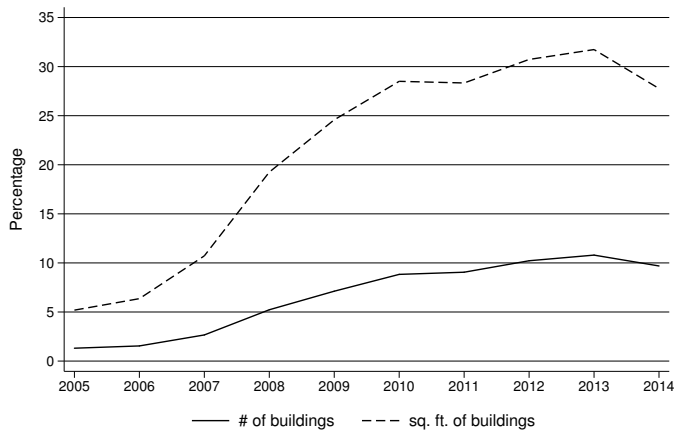

Panel C: LEED Adoption

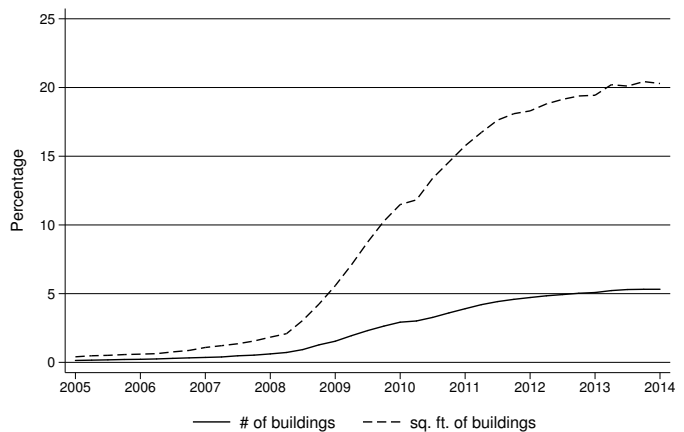

Notes: The above figures display the diffusion of the Energy Star rating and LEED certification program in the 30 largest U.S. office markets as depicted by CBRE research over time. The adoption percentage is calculated as the number or square footage of buildings in each market having an Energy Star or LEED certification relative to the size of the market-in number or square footage of buildings. CBRE's market size measures describe the competitive space in a market. This implies that owner occupied and government occupied assets are not included in the calculation. To recognize the depreciation of the environmental certification, we apply a two and five year label window for Energy Star and LEED, respectively. The presented numbers in Panel A are adjusted for buildings that obtained both certifications. 
2006 and Q1 2007. The repeated regression method is then modeled as follows:

$$
r_{i, t, s}=\sum_{j=1}^{T} \beta_{j} x_{i, j} * G_{i}+\alpha_{i}+\epsilon_{i}
$$

where the change in rent $r$ is explained by a set of time dummy variables $x$. This indicator variable takes a value of -1 if $j=t-s,+1$ if $j=t$, and 0 otherwise. We interact the set of time dummy variables with the variable of interest $G$, which indicates whether building $i$ was environmentally certified during the time period. Building level fixed effects are absorbed by $\alpha$ and $\epsilon$ is an error term. The standard errors are heteroscedasticity robust and clustered at the zip code level. The repeated measures rent index is estimated as follows:

$$
I_{t}=\exp \left(\beta_{t}\right), I_{0}=1, t=1, \ldots, T
$$

where the rent index $I$ is calculated as the exponential value of the income growth series $\beta$; Q1 2004 is used as the base quarter.

\subsubsection{Data}

To investigate the impact of environmental certification on the income pattern and value of commercial assets, we use multiple data sources. We first retrieve financial data on the U.S. commercial office market from CoStar Realty Information, Inc. (2013). CoStar Property is the leading commercial real estate database for the U.S. market. The coverage and information available at the level of the asset is quite extensive, and historical information is available regarding occupancy and rental levels. In addition, for the performance attribution analysis, the availability of detailed asset level information is required in order to be able to control for building quality characteristics that are correlated with environmental building certification. As discussed in the previous section, the USGBC and the EPA provide information regarding the environmental certification of buildings.

In order to construct the green building performance indices, we track the changes in the rent levels over 51 quarters, from Q1 2001 to Q3 2013, for a set of 43,719 individual office buildings. These buildings are located in the following metropolitan statistical areas: Atlanta, Chicago, Denver, Houston, Los Angeles, New York, San Francisco, and Washington D.C. These areas are the largest commercial office markets in the U.S. Moreover, these markets provide for both geographical variation in climate conditions as well as variation in underlying market dynamics. To construct the sample, the information on Energy Star and LEED certification is matched with the building information from CoStar, based on location. By employing GIS tools, the certification information is matched to building information using the longitudes and latitudes of each building. Some 2,300 buildings in the sample hold an environmental certification: 2,111 buildings are Energy Star labeled and 791 buildings are LEED certified (528 buildings hold both certifications).

The aim of the rent indices is to track the changes in market rent for environmentally certified and non-certified office buildings. Therefore, we only include an observation if new information is revealed: when the rent changes. ${ }^{9}$ Hence, we observe at least two different rental levels

\footnotetext{
${ }^{9}$ The rent measures we employ are asset level measures and by construction an aggregate of the
} 
with different time intervals for each building in our sample. The removal of these "stale" observations reduces the total sample to 26,876 observations, 2,002 of which are certified. ${ }^{10}$

In addition, following An and Pivo (2015) we exclude buildings for which the average change in the quarterly rental rate is smaller than -50 or larger than +50 percent, in order to remove erroneous information. This exercise reduces the sample to 25,690 buildings, of which 1,832 are certified. In total, we observe 268,617 quarterly records for 25,690 buildings, with an average of more than ten observations per building.

To take into account the "deprecation" of an Energy Star or LEED certificate, we apply a two and five-year label window, respectively. This rule implies that if a building is not re-certified after either a two or five-year period, we no longer classify it as certified and it returns to the non-certified part of the sample. ${ }^{11}$

\subsubsection{Descriptive Statistics}

Panels A to C of Figure 4.2 show how the variables of interest develop over time. Panel A shows the average total net asking rent for the certified buildings and non-certified buildings in our sample. On average, the total net asking rent is consistently higher for the environmentally certified buildings as compared to the non-certified buildings. Moreover, the difference in asking rent per square foot is increasing over time. Whereas the average difference in 2004 is about 15 percent this has increased to more than 30 percent in 2013.

Panel B of Figure 4.2 summarizes the average occupancy rate for environmentally certified and non-certified office buildings. The occupancy rate for non-certified buildings is on average seven percent lower than for certified buildings. However, in contrast to the trend we observe in the total net asking rent, this difference is slightly decreasing over time. While the average difference in occupancy rate in 2004 is more than seven percent, this reduced to less than five percent in 2013.

Panel $\mathrm{C}$ of Figure 4.2 shows the average effective rent over time. A similar trend is visible for the effective rent as for the total net asking rent, and certified buildings display a substantially higher effective rent as compared to non-certified buildings. On average, the difference between certified and non-certified buildings is almost 29 percent and is increasing over time.

\subsubsection{Environmental Certification Indices}

The indices estimated in Equation (4.3) are presented in Figure 4.3. The solid black line depicts the index for the certified buildings in our sample and the solid gray line provides the index for non-certified buildings. The dashed lines represent the 95 percent confidence interval for both

underlying individual leases. Therefore, we do not observe changes in the actual contract of these leases and are not able to distinguish between changes in total net asking rent that are due to a new contract, an altered contract, or a contractually determined rent step-up.

${ }^{10} \mathrm{By}$ definition a change in rent is necessary in order to estimate the index. Although the removal of these stale observations reduces the total sample by almost 39 percent, 87 percent of the identified certified buildings remain in the final sample.

${ }^{11}$ We use different label windows to ensure the robustness of our results. In general, lengthening the label window amplifies the differences between environmentally certified and non-certified buildings and vice versa. Nonetheless, our overall findings are robust to the choice of label window. The label window applied is the same as the window employed in the calculation of the adoption rates in the previous section. 
Figure 4.2: Rent and Occupancy Trends for Environmentally Certified and NonCertified Buildings

Panel A: Average Total Net Asking Rent

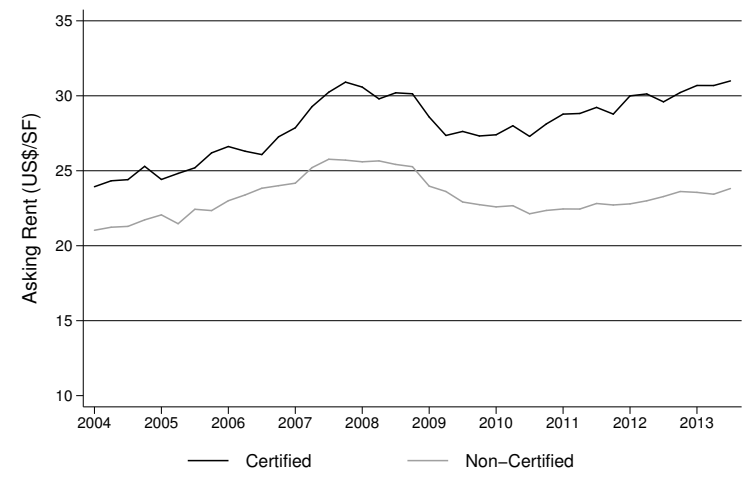

Panel B: Average Occupancy Rate

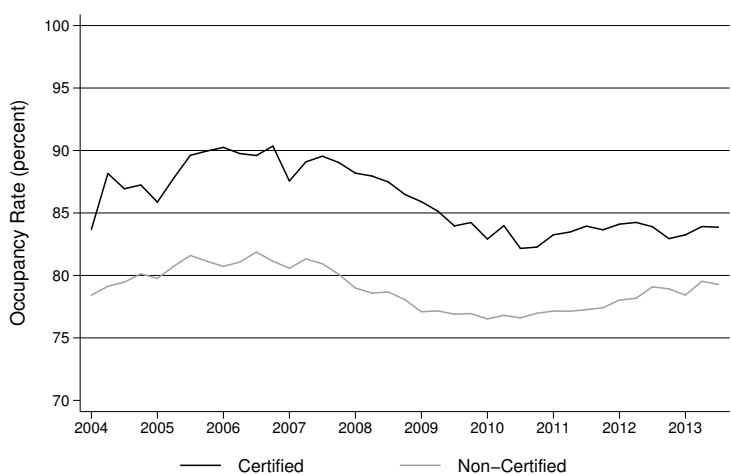

Panel C: Average Effective Rent

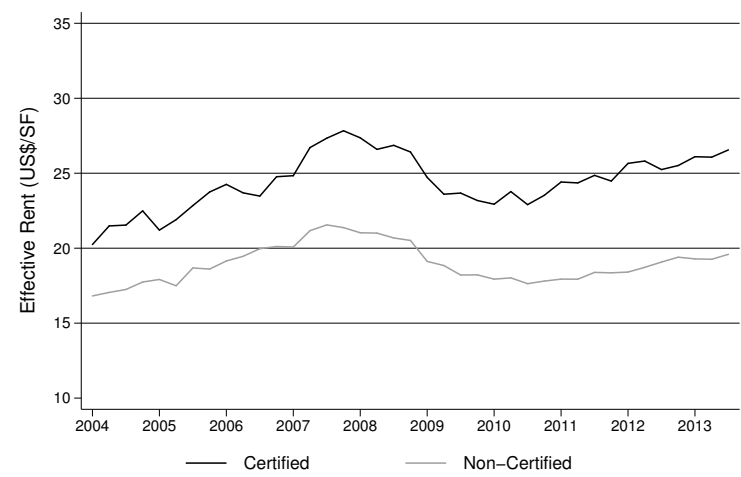

Notes: The above figures display the average asking rent, occupancy rate and effective rent, respectively for environmentally certified and non-certified buildings in the repeated rent sample. The black lines represent the environmentally certified assets, the gray lines denote the non-certified buildings. 
indices. The base quarter is Q1 2004. Although we have data available for earlier quarters, the limited amount of certified buildings in the early years of the sample period prevents estimating a reliable rent index for those quarters.

Panel A of Figure 4.3 shows the growth in total net asking rent for the 39 quarters until Q3 2013. The rental difference between environmentally certified and non-certified buildings is persistent throughout the entire sample period. However, the growth of the total net asking rent for the certified and non-certified assets does not significantly differ throughout the sample period, as displayed by the confidence intervals. The fact that the confidence intervals for the certified buildings are larger as compared to the index for the non-certified buildings can be attributed to the relatively small number of certified assets observed.

The peak of the market occurs in Q2 2008 according to the indices in Panel A of Figure 4.3. This is considerably later than suggested by the information provided by the National Bureau of Economic Research (NBER), which states that the peak of the business cycle occurred in December 2007. ${ }^{12}$ The same holds for the trough of the business cycle. Whereas the indices show their lowest points in Q1 2010, the NBER stipulates that the trough occurred in June 2009. Based on this comparison it seems that the estimated indices are slightly behind, reflecting the time necessary for the market for real assets to adjust to changing economic circumstances.

Environmentally certified buildings recovered somewhat more quickly from the real estate downturn than non-certified buildings, as shown by the break in Q2 2010. Nonetheless, the relative loss during the real estate market crash was larger for certified assets, a total decrease of 13.2 percent, as compared to 8.5 percent for non-certified assets. Interestingly, the non-certified index surpasses the certified index at the end of the sample period. The overall difference in growth over the sample period is relatively small -1.6 percent over almost 10 years. Whereas certified assets experience a total rental growth of 21.2 percent, the total growth for non-certified assets is 23.8 percent. These results suggest that the difference in rental rate levels between certified and non-certified assets is decreasing.

The difference in rental growth between certified and non-certified assets is more pronounced for the effective rent, as displayed in Panel B of Figure 4.3. Recall that the effective rent reflects both the occupancy rate and the rental level. However, in terms of statistical significance the index is not conclusive, as the number of environmentally certified buildings for which we can track the quarterly rental growth is quite limited.

The consistent difference in occupancy rates for environmentally certified real estate as compared to non-certified real estate amplifies the difference in rental growth for the effective rent estimations. The general trend we observe in Panel B is similar to the trend observed for the total net asking rent in Panel A. On average, the difference between the two indices throughout the sample period is 14.9 percent. At the peak of the market, based on the estimated indices, this was 19.3 percent. The difference in effective rent growth between the certified and non-certified buildings at the end of the sample period decreased to 9.2 percent.

The average annual rental growth, based on the estimated indices, over the entire sample period, as well as pre- and post-crisis, is documented in Table 4.1. Comparing the average rental growth both in terms of asking rent and effective rent of environmentally certified to non-certified buildings during the full sample period shows that certified buildings have a higher annual effective rental growth rate. This result is similar for the pre- and post-crisis

\footnotetext{
${ }^{12}$ The business cycle information is retrieved from: http://www.nber. org/cycles/cyclesmain.html.
} 
Figure 4.3: Asking Rent and Effective Rent Indices for Environmentally Certified and Non-Certified Buildings

Panel A: Total Net Asking Rent Growth

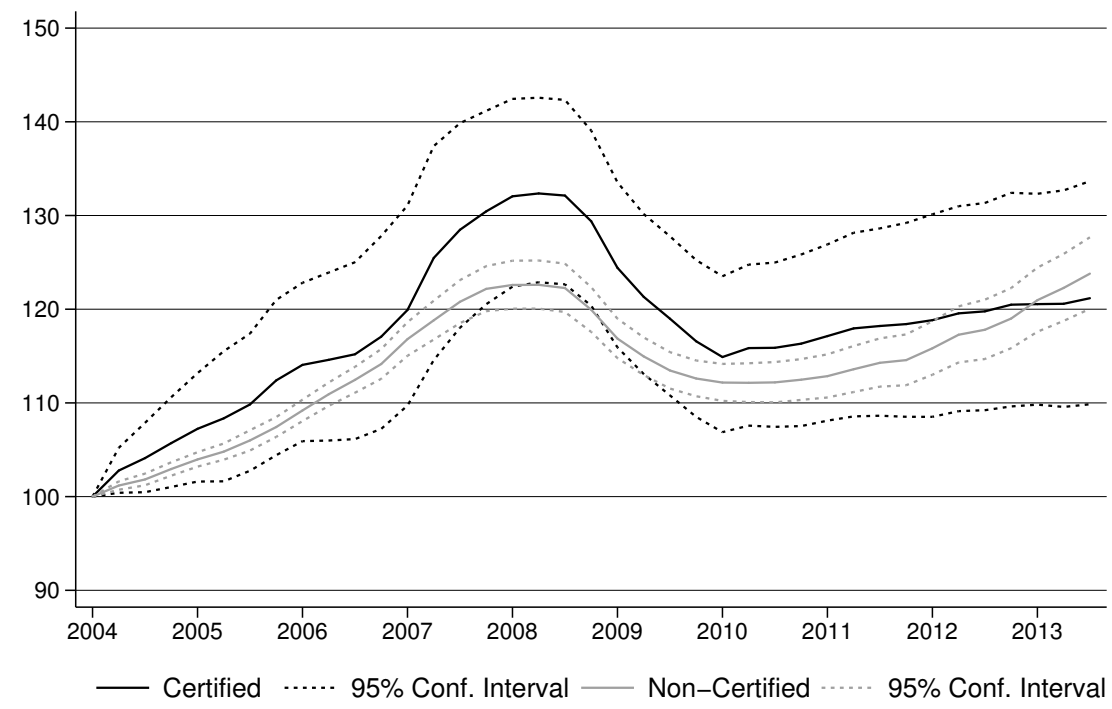

Panel B: Effective Rent Growth

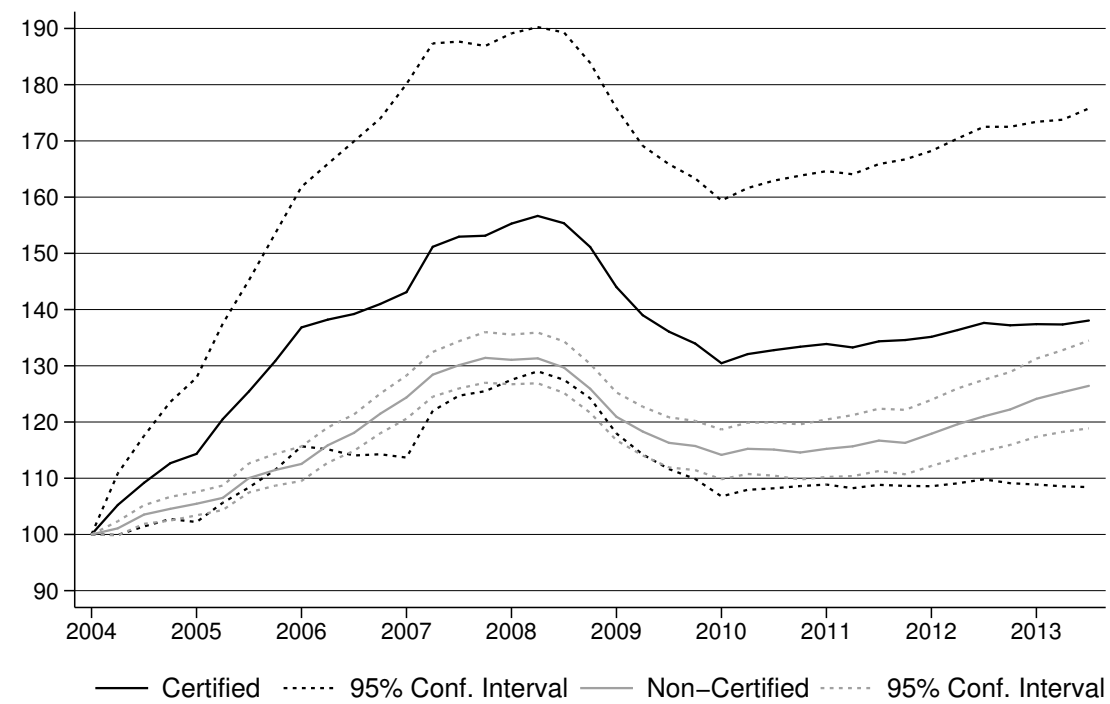

Notes: The above figures display the quarterly rental growth for environmentally certified and non-certified assets, represented by the black and gray lines, respectively. The dotted lines denote the 95 percent confidence intervals for the estimated indices. The base quarter for all indices is Q1 2004. 
period. It must be noted, however, that the size of the standard deviation can partially be explained by the relatively small sample of environmentally certified buildings.

The 13.2 percent decline for certified buildings after the burst of the real estate bubble as compared to 8.5 percent for non-certified buildings, can in part explain the larger average negative returns in the post-crisis period for the certified buildings.

Table 4.1: Average Annual Rental Growth for Environmentally Certified and Non-Certified Buildings

\begin{tabular}{llllrrrr}
\hline & \multicolumn{3}{c}{ Full Period } & \multicolumn{2}{c}{ 2004Q1-2008Q2 } & \multicolumn{2}{c}{ 2008Q3-2013Q3 } \\
& \multicolumn{3}{c}{ Certified Non-Certified } & Certified & Non-Certified & Certified & Non-Certified \\
\hline \multirow{2}{*}{ Asking Rent } & Average & 2.08 & 2.28 & 6.67 & 4.83 & -1.64 & 0.21 \\
& St. Dev. & 3.16 & 2.16 & 2.08 & 1.11 & 2.63 & 2.27 \\
\hline \multirow{2}{*}{ Effective Rent } & Average & 3.52 & 2.53 & 10.77 & 6.38 & -2.35 & -0.68 \\
& St. Dev. & 4.79 & 3.23 & 3.79 & 2.15 & 3.29 & 3.09 \\
\hline
\end{tabular}

Notes: The average annual rental growth, in percent, is based on the average quarterly change in the total net asking rent or effective rent per square foot. The results from two sample t-tests, comparing the average quarterly rental growth for certified and non-certified assets for the entire time period as well as pre- and post-crisis, indicate that only the effective rental growth in the pre-crisis period differ significantly from each other.

Previous studies have documented a significant rental premium, focusing on a single point in time (Chegut et al., 2014; Eichholtz et al., 2010, 2013; Fuerst and McAllister, 2011). Assessing the performance of these buildings over time provides some evidence that the effect of environmental certification on financial performance is not static. Overall, the difference in performance is decreasing over time and when evaluating the average returns and their standard deviations, there is no significant difference between returns and environmental certification.

\subsection{Marginal Certification Effects}

\subsubsection{Empirical Framework}

We use the standard real estate valuation framework in the form of a hedonic pricing model to investigate the marginal pricing effect for environmentally certified buildings (Rosen, 1974). Specifically, we use a semi-log equation relating the (effective) rent or transaction price per square foot to the observable characteristics and location of each building at a point in time:

$$
\log _{i, n}=\alpha+\sum_{j=1}^{J} \beta_{j} X_{i, j}+\sum_{n=1}^{N} \gamma_{n} c_{i, n}+\delta G_{i}+\tau G_{i} * D_{i}+\epsilon_{i}
$$

Where $\log R$ is the logarithm of the average weighted rent, effective rent, or transaction price of building $i$ in geographical cluster $n .{ }^{13} \mathrm{X}$ is a vector of hedonic characteristics $j$ (e.g. size, age, quality, etc.) of building $i$. We acknowledge that geographic differences between buildings may trump the marginal pricing effects of differences in "green" attributes. Therefore, we construct peer groups of nearest neighbors following the methodology of Eichholtz et al. (2010). Based on

\footnotetext{
${ }^{13}$ CoStar defines the average weighted rent as the average rental rate for all spaces in a building weighted according to the size of the space available.
} 
the location of each certified building, we select all nearby non-certified office buildings within a quarter mile radius. This leads to one geographic cluster for each certified building, including a set of control buildings against which comparisons are made. ${ }^{14}$ Each geographic cluster $c$ is an indicator variable taking the value of 1 if building $i$ is located in cluster $n$ and 0 otherwise. $G$ is the main variable of interest in our model. It is an indicator variable taking the value of 1 when building $i$ has an Energy Star label or LEED certificate and 0 otherwise. Interaction terms to measure the impact of local energy prices, climate conditions, and walkability of the location on the capitalization of environmental building certification are introduced through vector $D . \alpha$, $\beta, \gamma, \delta$, and $\tau$ are estimated coefficients, and $\epsilon$ is an error term.

$\delta$ is thus the average premium, in percent, estimated for certified buildings relative to those observationally similar buildings in its geographic cluster - the circle with a radius of a quarter mile. Standard errors are clustered at the geographic cluster level to control for spatial autocorrelation in rents and transaction prices within the cluster. In a second set of estimates, we include additional terms in Equation (4.4), further disentangling the "certification" indicator by its underlying attributes, such as labeling level, efficiency score, etc.

It is important to note that the information on the certified buildings in our sample is limited to observable characteristics, such as age, size and building quality. We do not have information on construction costs, quality of building management, and the presence of valuable attributes that may be correlated with environmental building certification. For example, we cannot control for the possibility that some developers choose to systematically bundle environmental attributes with other amenities, such as more valuable appliances or a higher-quality finishing. We assume that such unobservable characteristics are not systematically correlated with environmental certification. Otherwise, we would overestimate the effects of environmental certification on office rents and transaction prices. To alleviate concerns about unobservables, we apply propensity score weighting throughout all analyses, in order to account for the differences between "treated" certified buildings and "untreated" non-certified buildings. The propensity score weights are based on the size of the buildings. ${ }^{15}$

\subsubsection{Data}

The data used for the cross-sectional analyses differ slightly from those employed for the rent indices. Most importantly, the cross-sectional analysis spans the entire U.S. national commercial office market, included in the CoStar universe as of Q3 2013, and includes information on the rent level as well as the last recorded transaction price of the asset. The information in the CoStar database is matched against the information available in the Green Building Information Gateway (GBIG), a database maintained by the USGBC, to identify environmentally certified commercial assets. In total, we identify 5,023 certified office buildings; of which 4,463 are Energy Star labeled and 1,527 received a LEED certificate by the USGBC ( 967 buildings obtained both ratings).

The cross-sectional sample resulting from the construction of 5,023 unique clusters contains

\footnotetext{
${ }^{14}$ Each cluster contains one certified buillding. Nevertheless, clusters may overlap and control buildings may be included in the total sample more than once.

${ }^{15}$ We tested various propensity score specifications; the specification applied here most optimally explains the likelihood of environmental certification and satisfies the balancing property of the propensity score estimation procedure.
} 
91,572 office buildings, of which 5,023 buildings are certified. For a building to be included in the analysis, complete information needs to be available on all quality characteristics. In addition, the final sample only includes locational clusters with at least one environmentally certified and one non-certified building. These restrictions lead to a rental sample of 27,829 office buildings, 2,772 of which have an Energy Star rating and 834 are certified under the LEED program (574 buildings have obtained both ratings). The transaction sample includes a total of 11,603 office buildings, 777 of these assets are Energy Star rated and 306 hold a LEED certification (229 buildings obtained both ratings). The transaction sample spans the time period from Q1 1999, when the Energy Star and LEED certification were introduced, to Q3 2013.

\subsubsection{Descriptive Statistics}

Table 4.2 summarizes the average building characteristics for the buildings included in the rental and transaction samples, differentiating between environmentally certified and non-certified buildings. The first two columns of Table 4.2 provide the characteristics of the buildings in the non-certified and certified rental sample. The last two columns of Table 4.2 present the characteristics of the non-certified and certified buildings included in the transaction sample.

The average office building in the non-certified sample commands a rent of some 28 dollars per square foot and is 84 percent occupied. The effective rent for non-certified office buildings is about 24 dollar per square foot. Regarding the size of the buildings, the average office spans some 132,000 square feet, divided over ten stories. With respect to building quality, almost 60 percent of the buildings are designated as quality Class B with approximately even distributions for Class A and Class C buildings. The average commercial building in the sample is almost 37 years old, and 40 percent of the buildings are renovated. ${ }^{16}$ On-site amenities are present for 17 percent of the buildings. ${ }^{17}$ Moreover, on average the non-certified buildings in the rental sample are in highly walkable locations, with an average Walkscore of 84 .

The comparison between non-certified and environmentally certified buildings shows some interesting differences. The average certified building commands a lower rent per square foot as compared to a non-certified building. Although the occupancy rate is slightly higher for certified buildings, the effective rent for non-certified buildings is higher as compared to the effective rent of certified buildings. This difference may, of course, be explained by other factors, such as geographic differences, and the large differences with respect to the size of the buildings, but these point in the opposite direction. Environmentally certified buildings are almost twice as large as compared to non-certified buildings.

Also, whereas almost 70 percent of the certified office buildings are classified as Class A, just 20 percent of the non-certified buildings achieve this rating. The difference in Class B buildings is the reverse; only 31 percent of the certified buildings have this rating, as compared to 57 percent of the non-certified buildings. Virtually no certified buildings are designated as Class C, whereas 22 percent of the non-certified buildings fall into this category. Certified office buildings are on average more than 15 years younger as compared to non-certified office buildings, and not surprisingly, certified buildings are less often renovated. On-site amenities are present in

\footnotetext{
${ }^{16}$ In this specification we define age relative to the year of construction or the year of the last major renovation.

${ }^{17}$ One or more of the following amenities are available on-site: convenience store, dry cleaner, exercise facilities, food court, mail room, retail shops, vending areas, fitness center.
} 
42 percent of the certified office buildings. Interestingly, the average Walkscore for certified buildings is much lower compared to the Walkscore for non-certified buildings. ${ }^{18}$

Table 4.2: Descriptive Statistics

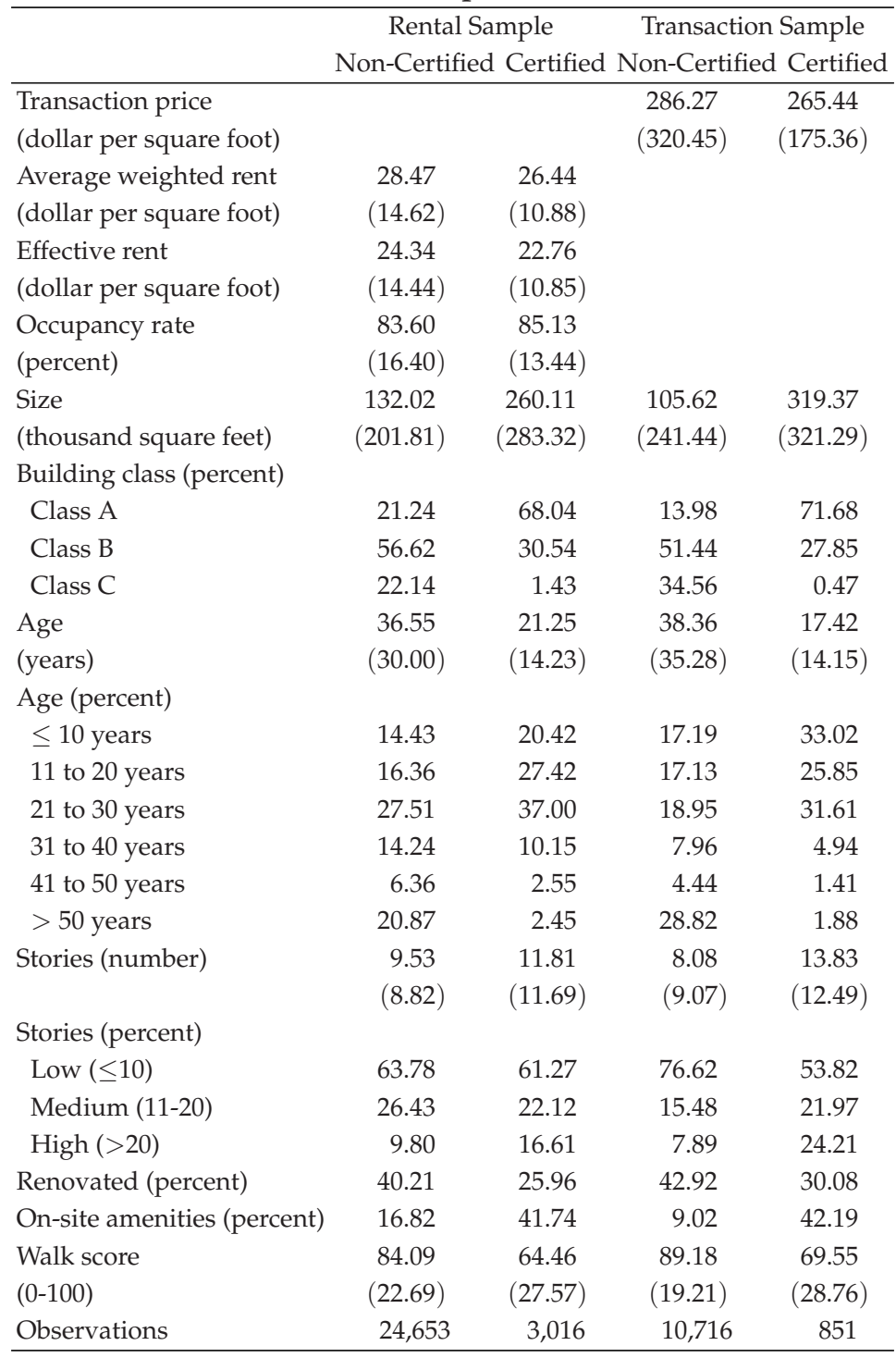

Notes: Standard deviations in parentheses.

The differences between non-certified and certified buildings in the transaction sample are even more pronounced. Compared to non-certified buildings, certified office buildings sell for less; the average transaction price per square foot is more than USD 20 lower. Part of the difference in average transaction price might be explained by the fact that certified buildings in

\footnotetext{
${ }^{18}$ Due to the construction of location clusters with a quarter mile radius for each certified building we may observe non-certified buildings multiple times. To some extent this may explain the higher average Walkscore for non-certified buildings as compared to certified office buildings.
} 
the transaction sample are more than three times as large as compared to non-certified building in terms of square footage. The large difference in size is displayed in the number of stories as well.

We observe a similar tendency comparing the quality characteristics of certified office buildings to non-certified buildings. 72 percent of the certified buildings are Class A, while this only holds for 14 percent of the non-certified buildings. Only 28 percent of the certified buildings have a Class B designation, whereas this building class represents the majority of the buildings in the non-certified sample. The fact that no certified building is labeled as Class $\mathrm{C}$ further underlines the large differences in building quality. Moreover, certified buildings are, on average, more than twice as new as compared to non-certified buildings. The differences in building age might explain that certified buildings are less often renovated compared to non-certified buildings. On-site amenities are present in 62 percent of the certified buildings compared to a mere 26 percent for the non-certified buildings. Similar to the rental sample, the Walkscore for the certified buildings in the transaction sample is significantly lower than the Walkscore for the non-certified buildings.

\subsection{Empirical Results}

\subsubsection{Marginal Effects}

Table 4.3 presents the results of estimating Equation (4.4). We first investigate the marginal effects of environmental certification and then decompose these effects into specific performance attributes. The specifications displayed employ the average weighted rent, effective rent, and transaction price as dependent variables. These variables are related to the hedonic and geographical characteristics of the buildings in our sample. The explanatory power of the specifications presented in Table 4.3 is quite strong: they explain between 68 and 78 percent of the variation in the dependent variable. ${ }^{19}$

Column (1) presents the results regarding the relationship between environmental certification and the average weighted rent per square foot. The quality rating of a building as measured by the building class categories has a strong impact on the rental level. Compared to a Class $\mathrm{C}$ building a Class A building commands a 13.2 percent premium. The rental increment for a Class B building is 4.2 percent. Interestingly, the Walkscore as an additional measure of location quality is negatively related to the average weighted rent of an office building, although this effect is small. This is in contrast with the effects documented by Pivo and Fisher (2011), who document a 0.9 percent increase in market value and a 0.7 percent increase in net operating income for a one-point increase in the Walkscore of office buildings. Moreover, building size and the occupancy rate have a positive and significant impact on the rental level of office buildings. The findings with respect to size and building quality are in line with the results documented by Eichholtz et al. (2013).

\footnotetext{
${ }^{19}$ Table A.1 displays the full results with respect to all the building characteristics included in our specifications.
} 
Table 4.3: Environmental Certification, Rent, and Transaction Price

\begin{tabular}{|c|c|c|c|c|c|c|}
\hline & \multicolumn{2}{|c|}{ Average Weighted Rent } & \multicolumn{2}{|c|}{ Effective Rent } & \multicolumn{2}{|c|}{ Transaction Price } \\
\hline & (1) & (2) & (3) & (4) & (5) & (6) \\
\hline \multirow[t]{2}{*}{ Green (1=yes) } & $0.025^{* * *}$ & & $0.052^{* * *}$ & & $0.144^{* * *}$ & \\
\hline & {$[0.005]$} & & {$[0.007]$} & & {$[0.026]$} & \\
\hline \multirow[t]{2}{*}{ Energy Star (1=yes) } & & $0.015^{* * *}$ & & $0.038^{* * *}$ & & $0.100^{* * *}$ \\
\hline & & {$[0.006]$} & & {$[0.008]$} & & {$[0.028]$} \\
\hline \multirow[t]{2}{*}{ LEED (1=yes) } & & $0.023^{* *}$ & & $0.034^{* *}$ & & $0.189^{* * *}$ \\
\hline & & {$[0.010]$} & & {$[0.014]$} & & {$[0.049]$} \\
\hline Log size & $0.044^{* * *}$ & $0.044^{* * *}$ & $0.070^{* * *}$ & $0.071^{* * *}$ & $-0.101^{* * *}$ & $-0.101^{* * *}$ \\
\hline (thousand square feet) & {$[0.003]$} & {$[0.003]$} & {$[0.004]$} & {$[0.004]$} & {$[0.015]$} & {$[0.015]$} \\
\hline Occupancy rate & $0.048^{* * *}$ & $0.049^{* * *}$ & & & & \\
\hline$(0-1)$ & {$[0.012]$} & {$[0.012]$} & & & & \\
\hline \multicolumn{7}{|l|}{ Building class (1=yes) } \\
\hline \multirow[t]{2}{*}{ Class A } & $0.132^{* * *}$ & $0.132^{* * *}$ & $0.134^{* * *}$ & $0.134^{* * *}$ & $0.534^{* * *}$ & $0.536^{* * *}$ \\
\hline & {$[0.009]$} & {$[0.009]$} & {$[0.011]$} & {$[0.011]$} & {$[0.052]$} & {$[0.052]$} \\
\hline \multirow[t]{2}{*}{ Class B } & $0.042^{* * *}$ & $0.042^{* * *}$ & $0.052^{* * *}$ & $0.052^{* * *}$ & $0.227^{* * *}$ & $0.230^{* * *}$ \\
\hline & {$[0.008]$} & {$[0.008]$} & {$[0.009]$} & {$[0.009]$} & {$[0.038]$} & {$[0.038]$} \\
\hline \multirow[t]{2}{*}{ Walkscore (0-10) } & $-0.010^{* * *}$ & $-0.010^{* * *}$ & $-0.010^{*}$ & $-0.010^{*}$ & -0.014 & -0.009 \\
\hline & {$[0.004]$} & {$[0.004]$} & {$[0.005]$} & {$[0.005]$} & {$[0.019]$} & {$[0.020]$} \\
\hline Building characteristics & yes & yes & yes & yes & yes & yes \\
\hline Location clusters & yes & yes & yes & yes & yes & yes \\
\hline Quarter-year fixed effects & no & no & no & yes & yes & yes \\
\hline \multirow[t]{2}{*}{ Constant } & $2.977^{* * *}$ & $2.977^{* * *}$ & $2.686^{* * *}$ & $2.686^{* * *}$ & $4.432^{* * *}$ & $4.383^{* * *}$ \\
\hline & {$[0.035]$} & {$[0.035]$} & {$[0.049]$} & {$[0.049]$} & {$[0.223]$} & {$[0.228]$} \\
\hline Observations & 27,669 & 27,669 & 27,669 & 27,669 & 11,567 & 11,567 \\
\hline$R^{2}$ & 0.80 & 0.80 & 0.73 & 0.73 & 0.71 & 0.71 \\
\hline Adj. $R^{2}$ & 0.78 & 0.78 & 0.70 & 0.70 & 0.68 & 0.68 \\
\hline
\end{tabular}

Notes: Table 4.3 shows the results from a propensity score weighted regression model using the logarithm of the average weighted rent, effective rent, or transaction price per square foot as dependent variable. Robust standard errors clustered for each location cluster in brackets. Significance at the $0.10,0.05$ and 0.01 level is indicated by ${ }^{*}, * *$ and ${ }^{* * *}$ respectively.

Energy Star or LEED certified buildings command a rent premium of 2.5 percent. This effect is economically quite large: at the point of means, the average non-certified building in our sample would command an increased income of more than USD 94,000 per year if it were certified. Column (2) distinguishes between Energy Star and LEED certified office buildings. The effects of building size and building quality are similar to the effects observed in Column (1). Energy Star rated buildings rent for 1.5 percent more compared to non-rated buildings; the rent increment for LEED certified office buildings is slightly higher, at 2.3 percent.

Columns (3) and (4) employ the effective rent as the dependent variable. Environmentally certified office buildings command a 5.2 percent higher effective rent as compared to noncertified buildings. The average non-certified building in our sample would extract about USD 167,000 in additional cash flow per year if it were certified. Applying a capitalization rate of 6 percent, this translates to an increase in market value of some USD 2.8 million. The impact of an Energy Star rating is 3.8 percent; LEED certified buildings have a 3.4 percent higher cash flow. In general, the relationship between the effective rent, building size and building quality is 
similar to the effects we document in the specifications for the average weighted rent; larger buildings and buildings of higher quality are leased for more.

Columns (5) and (6) of Table 4.3 present the results for the transaction sample, which includes building transactions from Q1 1999 to Q3 2013. Building quality has a positive and significant impact on the transaction price as displayed by the coefficient on Class A and Class B. In contrast to the findings for the rental sample, the Walkscore associated with a building or location is not significantly related to the transaction price. Large buildings sell for less, in relative terms, as indicated by the negative coefficient on building size.

Buildings with either an Energy Star or LEED certificate transact for 14.4 percent more as compared to non-certified buildings. This implies a price premium of almost USD 4.4 million for the average non-certified office building if it were to transact as a environmentally certified building. Differentiating between the Energy Star and LEED certificate in column (6) shows that Energy Star rated buildings transact for 10 percent more, while a LEED certificate commands a 18.9 percent premium, on average.

Overall, the results in Table 4.3 confirm earlier findings that environmentally certified buildings command higher rents and transaction prices, using a significantly larger sample, but also a more recent time period, in which many more commercial buildings have obtained an environmental certification and competition has thus increased (Chegut et al., 2014; Eichholtz et al., 2010, 2013; Fuerst and McAllister, 2011). However, there is some indication of significant heterogeneity with respect to the measurement of economic performance, and with respect to the type of environmental certificate.

Table 4.4 presents a set of models investigating the interaction between environmental certification and climate, energy price, location and size effects to distinguish between the energy efficiency and environmental aspects of the certification and other heterogeneous effects. The specifications in columns (1) and (4) examine the impact of environmental certification in more extreme climates for the rental and transaction sample by interacting the total monthly degree days with environmental certification. ${ }^{20}$ The results show that environmentally certified office buildings in more extreme climates are more valuable as compared to certified office buildings in more moderate climates. At the average temperature level, the certification premium is 4.2 and 7.1 percent for the rental and transaction sample, respectively. However, a one standard deviation (some 153 and 265 degree days for the rental and transaction sample, respectively) increase in degree days increases the certification premium by 2.3 and 5.3 percent, respectively.

Including the impact of local electricity prices, measured at the county-month level, in columns (2) and (5) indicates that, although the premium for environmental certification is higher for buildings in locations with more extreme climates, higher electricity prices have a slightly negative impact on the value increment. ${ }^{21}$ At the point of means this implies an average combined environmental certification premium of 3.1 and 6.3 percent for the rental and transaction sample respectively, which increases with an increase in the monthly degree days and decreases with increasing electricity prices.

\footnotetext{
${ }^{20}$ Monthly heating and cooling degree day information is collected for all weather stations in the U.S. from the National Oceanic and Atmospheric Administration from January 1999 to December 2013. This information is then matched to the observations in both samples based on the geographically nearest weather station and the month of observation.

${ }^{21}$ Monthly electricity prices at the county level are retrieved from the Energy Information Administration from January 1999 to December 2013.
} 
Table 4.4: Environmental Certification and Heterogeneous Price Effects

\begin{tabular}{|c|c|c|c|c|c|c|}
\hline & \multicolumn{3}{|c|}{ Effective Rent } & \multicolumn{3}{|c|}{ Transaction Price } \\
\hline & (1) & (2) & (3) & (4) & (5) & (6) \\
\hline \multirow[t]{2}{*}{ Green (1=yes) } & 0.012 & 0.021 & $0.118^{* * *}$ & 0.064 & $0.082^{*}$ & $-0.104^{*}$ \\
\hline & {$[0.014]$} & {$[0.015]$} & [0.019] & {$[0.045]$} & {$[0.046]$} & {$[0.060]$} \\
\hline Green * Degree days & $0.015^{* * *}$ & $0.024^{* * *}$ & & $0.020^{* *}$ & $0.040^{* * *}$ & \\
\hline (monthly total) & {$[0.004]$} & {$[0.006]$} & & {$[0.009]$} & {$[0.014]$} & \\
\hline Green * Degree days* & & $-0.001^{* *}$ & & & $-0.002^{*}$ & \\
\hline Electricity price & & {$[0.000]$} & & & {$[0.001]$} & \\
\hline Green * Walkscore & & & $-0.009^{* * *}$ & & & $0.030^{* * *}$ \\
\hline$(0-10)$ & & & {$[0.002]$} & & & {$[0.008]$} \\
\hline Log size & $0.070^{* * *}$ & $0.071^{* * *}$ & $0.070^{* * *}$ & $-0.101^{* * *}$ & $-0.100^{* * *}$ & $-0.101^{* * *}$ \\
\hline (thousand square feet) & {$[0.004]$} & {$[0.004]$} & {$[0.004]$} & {$[0.015]$} & {$[0.015]$} & {$[0.015]$} \\
\hline \multicolumn{7}{|l|}{ Building class (1=yes) } \\
\hline \multirow[t]{2}{*}{ Class A } & $0.135^{* * *}$ & $0.135^{* * *}$ & $0.134^{* * *}$ & $0.532^{* * *}$ & $0.530^{* * *}$ & $0.534^{* * *}$ \\
\hline & {$[0.011]$} & {$[0.011]$} & {$[0.011]$} & {$[0.052]$} & {$[0.052]$} & {$[0.052]$} \\
\hline \multirow[t]{2}{*}{ Class B } & $0.052^{* * *}$ & $0.052^{* * *}$ & $0.052^{* * *}$ & $0.227^{* * *}$ & $0.226^{* * *}$ & $0.228^{* * *}$ \\
\hline & {$[0.009]$} & {$[0.009]$} & {$[0.009]$} & {$[0.038]$} & {$[0.038]$} & {$[0.038]$} \\
\hline Building characteristics & yes & yes & yes & yes & yes & yes \\
\hline Location clusters & yes & yes & yes & yes & yes & yes \\
\hline Quarter-year effects & no & no & no & yes & yes & yes \\
\hline \multirow[t]{2}{*}{ Constant } & $2.599^{* * *}$ & $2.598^{* * *}$ & $2.598^{* * *}$ & $4.304^{* * *}$ & $4.303^{* * *}$ & $4.314^{* * *}$ \\
\hline & {$[0.017]$} & {$[0.017]$} & {$[0.017]$} & {$[0.136]$} & [0.137] & {$[0.137]$} \\
\hline Observations & 27,669 & 27,669 & 27,669 & 11,567 & 11,567 & 11,567 \\
\hline $\mathrm{R}^{2}$ & 0.74 & 0.74 & 0.74 & 0.71 & 0.71 & 0.71 \\
\hline Adj. $R^{2}$ & 0.70 & 0.70 & 0.70 & 0.68 & 0.68 & 0.68 \\
\hline
\end{tabular}

Notes: Table 4.4 shows the results of a propensity score weighted regression model using the logarithm of the effective rent or transaction price per square foot as dependent variables. Robust standard errors clustered for each location cluster in brackets. Significance at the $0.10,0.05$ and 0.01 level is indicated by ${ }^{*}, * *$ and ${ }^{* * *}$ respectively.

Columns (3) and (6) examine the relationship between location quality and environmental certification, using the Walkscore as a proxy for location quality. Interestingly, the interaction effects for the rental and transaction sample move in opposite directions: environmentally certified buildings in a highly walkable location rent for less but transact for more. ${ }^{22}$ A one-point increase in the Walkscore yields a 0.09 percent discount in the rental sample and a 0.30 percent premium in the transaction sample. Of course, the effective rent is a reflection of a single point in time (Q3 2013), whereas sales prices are measured over a larger sample period. This result maybe related to current market dynamics on environmental certification: premiums may be more pronounced in generally less walkable cities where supply of certified space is still low relative to, for example, more walkable cities like San Francisco.

The previous analysis established the robustness of the base model and the heterogeneity in the marginal impact of environmental building certification. We also examine the effect of the energy efficiency and environmental attributes underlying environmental certification, on the effective rent and transaction price of commercial buildings.

\footnotetext{
${ }^{22}$ The overall effect is stable to alternative definitions of location quality where we employ different cut-off values for the Walkscore to create an indicator variable.
} 
Table 4.5: Certification Characteristics (Energy Star and LEED)

\begin{tabular}{|c|c|c|c|c|}
\hline \multirow{2}{*}{ A. Energy Star Rated Buildings } & \multicolumn{2}{|c|}{ Rental Sample } & \multicolumn{2}{|c|}{ Transaction Sample } \\
\hline & Mean & Standard Dev. & Mean & Standard Dev. \\
\hline Rating (75-100) & 84.64 & 6.63 & 84.53 & 6.78 \\
\hline Number of ratings & 3.26 & 2.32 & 2.73 & 2.06 \\
\hline Vintage (years) & 1.06 & 1.53 & 1.05 & 1.46 \\
\hline Observations & & 2,757 & & 769 \\
\hline \multirow{2}{*}{ B. LEED Certified Buildings } & \multicolumn{2}{|c|}{ Rental Sample } & \multicolumn{2}{|c|}{ Transaction Sample } \\
\hline & Mean & Standard Dev. & Mean & Standard Dev. \\
\hline \multicolumn{5}{|l|}{ Program (percent) } \\
\hline New construction & 3.37 & & 10.95 & \\
\hline Core and shell & 14.54 & & 23.88 & \\
\hline Existing buildings & 82.09 & & 65.17 & \\
\hline Total score $(0-100)$ & 53.03 & 8.71 & 55.06 & 9.43 \\
\hline \multicolumn{5}{|l|}{ Category $(0-100)$} \\
\hline Energy and atmosphere & 52.43 & 17.74 & 50.96 & 18.63 \\
\hline Innovative design & 89.76 & 17.21 & 88.01 & 19.61 \\
\hline Indoor environmental quality & 64.51 & 15.17 & 64.27 & 14.25 \\
\hline Material and resources & 43.88 & 17.96 & 48.33 & 20.26 \\
\hline Sustainable sites & 44.41 & 19.49 & 48.38 & 19.38 \\
\hline Water efficiency & 54.14 & 19.03 & 53.92 & 18.86 \\
\hline Vintage (years) & 2.10 & 1.36 & 1.69 & 1.19 \\
\hline \multicolumn{5}{|l|}{ Certification level (percent) } \\
\hline Certified & 15.26 & & 12.44 & \\
\hline Silver & 32.33 & & 30.85 & \\
\hline Gold & 48.08 & & 49.25 & \\
\hline Platinum & 4.33 & & 7.46 & \\
\hline Observations & & 832 & & 201 \\
\hline
\end{tabular}

Table 4.5 displays the average environmental attributes for the Energy Star and LEED certified buildings in the two samples. The Energy Star rated buildings in the rental and transaction sample have an average rating of almost 85 points, on a 0 to 100 scale. Interestingly, Energy Star rated buildings, on average, received a rating three times, with a maximum of fourteen certifications. The label vintage for Energy Star rated buildings is about one year, and the first Energy Star certification occurred in 1999.

Panel B of Table 4.5 shows that 82 percent of the 832 LEED certified office buildings in our rental sample are certified under the LEED for Existing Buildings program, as compared to 65 percent of the 201 LEED certified buildings included in the transaction sample. The programs Core and Shell and New Construction together account for the remaining 18 percent and 35 percent of the LEED sample, respectively. ${ }^{23}$ The average LEED score for certified buildings in both the rental and transaction sample is 53 and 55 points, on a 0 to 100 scale. The different categories show that the buildings in our sample score highest on "Innovative Design" and "Indoor Environmental Quality." The vintage for LEED certification is higher as compared to the

\footnotetext{
${ }^{23}$ LEED for Commercial Interiors is deliberately excluded from all the presented analyses. LEED for Commercial Interiors often affects only part of a building and is regarded as a tenant initiative. Since we observe financial information at the asset level, these tenant-level observations are not included.
} 
Energy Star rated buildings, with an average of 2.1 years for the rental sample and 1.7 years for the transaction sample. This can be explained by the fact that LEED certified buildings are less frequently recertified than Energy Star rated buildings.

Table 4.6 presents the results of the estimation of the different environmental attributes and the effective rent per square foot (control variables are omitted from the Table). Similar to the specifications described above, the models in Table 4.6 explain some 70 percent of the variation in the effective rent of the office buildings in the rent sample.

Column (1) shows that an Energy Star rated building commands a 4.6 percent higher effective rent, but the vintage of an Energy Star rating has a significantly negative impact on the certification premium. On average, the premium for an Energy Star rated building decreases with 0.8 percent for every year the rating ages.

Column (2) investigates the impact of the rating level for Energy Star certified buildings. The rating coefficient indicates that the premium for Energy Star buildings increase with 0.04 percent for every one-point increase in the rating. This implies that a building with the minimum Energy Star rating of 75 points rents for 3 percent more, increasing to a rent premium of 4 percent for a building with the maximum rating of 100 points. Buildings with both an Energy Star and LEED certificate command a 3.3 percent higher rent in addition to the Energy Star premium. ${ }^{24}$

Column (3) analyzes the relationship between the LEED score and the associated rent increment. ${ }^{25}$ The coefficient on the LEED score indicates that a one-point increase in the LEED score yields a 0.5 percent increase in the rent premium. This implies a rent increment of 1.8 percent at the minimum LEED score. At the average score of 53 points the rent increment associated with a LEED certification is 2.7 percent. Moreover, the indicator variable for an Energy Star label displays an additional 3.9 percent premium for buildings with both certifications.

Column (4) further disentangles the impact of the different LEED programs. The rent increment is highest for the New Construction program at 12.3 percent. Buildings certified under the LEED for Core and Shell program command a 8.2 percent premium in effective rent. The rent premium for LEED for Existing Buildings is just 2.5 percent, although insignificant. However, most of the buildings certified under the LEED for Existing Buildings program have an Energy Star label as well - this holds for 79 percent of the observations - the total rent premium for such buildings is 3.9 percent. Overall, the results in column (4) indicate that the rent increment associated with a LEED certificate is higher for newly constructed buildings as compared to existing buildings.

Column (5) displays the results for different LEED rating levels. LEED Certified buildings achieve the highest rent premium, at 9.4 percent. The other LEED rating levels - Silver, Gold, and Platinum - do not command a significant rent premium as compared to non-certified office buildings, although the positive coefficients point towards the expected direction.

Column (6) documents the impact of the different LEED credit categories on the effective rent. The categories Water Efficiency and Materials and Resources have a significant positive impact on the effective rent level, whereas each additional point in the category Sustainable Sites leads

\footnotetext{
${ }^{24}$ In an alternative specification, Energy Stare rating squared is included to examine a possible nonlinear relationship between the rent increment and the Energy Star rating. The coefficient on this variable is not significant, although the negative coefficient points in the expected direction.

${ }^{25}$ We include LEED score squared in an alternative specification to examine the potential non-linear relationship between the LEED score and the effective rent level. The coefficient on this variable is not significant, although the negative coefficient points in the expected direction.
} 
to a discount. Multiplying these effects with the average scores for each category implies that the average LEED certified building in our sample rents for 9.5 percent more. Importantly, this regression controls for the presence of an Energy Star rating, which may explain the insignificant results for the "Energy and Atmosphere" variable.

Table 4.6: Certification Characteristics and Effective Rents

\begin{tabular}{|c|c|c|c|c|c|c|}
\hline & (1) & (2) & (3) & (4) & (5) & (6) \\
\hline Energy star & $0.046^{* * *}$ & & $0.039^{* * *}$ & $0.039^{* * *}$ & $0.039^{* * *}$ & $0.041^{* * *}$ \\
\hline (1=yes) & {$[0.009]$} & & {$[0.008]$} & {$[0.008]$} & {$[0.008]$} & {$[0.008]$} \\
\hline $\begin{array}{l}\text { Energy star vintage } \\
\text { (years) }\end{array}$ & $\begin{array}{r}-0.008^{*} \\
{[0.005]}\end{array}$ & & & & & \\
\hline Energy star rating & & $0.004^{* * *}$ & & & & \\
\hline$(0-10)$ & & {$[0.001]$} & & & & \\
\hline LEED & $0.030^{* *}$ & $0.033^{* *}$ & & & & \\
\hline (1=yes) & {$[0.014]$} & {$[0.014]$} & & & & \\
\hline LEED score & & & $0.005^{* *}$ & & & \\
\hline$(0-10)$ & & & {$[0.003]$} & & & \\
\hline \multicolumn{7}{|l|}{ LEED program (1=yes) } \\
\hline \multirow{2}{*}{ Core and shell } & & & & $0.082^{* *}$ & & \\
\hline & & & & {$[0.036]$} & & \\
\hline \multirow[t]{2}{*}{ New construction } & & & & $0.123^{*}$ & & \\
\hline & & & & {$[0.069]$} & & \\
\hline \multirow[t]{2}{*}{ Existing buildings } & & & & 0.025 & & \\
\hline & & & & {$[0.015]$} & & \\
\hline \multicolumn{7}{|l|}{ LEED certification level (1=yes) } \\
\hline \multirow[t]{2}{*}{ Certified } & & & & & $0.094^{* * *}$ & \\
\hline & & & & & {$[0.029]$} & \\
\hline \multirow[t]{2}{*}{ Silver } & & & & & 0.024 & \\
\hline & & & & & {$[0.025]$} & \\
\hline \multirow[t]{2}{*}{ Gold } & & & & & 0.021 & \\
\hline & & & & & {$[0.019]$} & \\
\hline \multirow[t]{2}{*}{ Platinum } & & & & & 0.044 & \\
\hline & & & & & {$[0.046]$} & \\
\hline \multicolumn{7}{|l|}{ LEED rating by category $(0-10)$} \\
\hline \multirow[t]{2}{*}{ Energy and atmosphere } & & & & & & -0.007 \\
\hline & & & & & & {$[0.008]$} \\
\hline \multirow[t]{2}{*}{ Innovative design } & & & & & & -0.005 \\
\hline & & & & & & {$[0.006]$} \\
\hline \multirow[t]{2}{*}{ Indoor environmental quality } & & & & & & 0.004 \\
\hline & & & & & & {$[0.009]$} \\
\hline \multirow[t]{2}{*}{ Materials and resources } & & & & & & $0.017^{* *}$ \\
\hline & & & & & & {$[0.007]$} \\
\hline \multirow[t]{2}{*}{ Sustainable sites } & & & & & & $-0.021^{* * *}$ \\
\hline & & & & & & {$[0.006]$} \\
\hline \multirow[t]{2}{*}{ Water efficiency } & & & & & & $0.021^{* * *}$ \\
\hline & & & & & & [0.007] \\
\hline Building characteristics & yes & yes & yes & yes & yes & yes \\
\hline Location clusters & yes & yes & yes & yes & yes & yes \\
\hline
\end{tabular}


Table 4.6 (continued from previous page)

\begin{tabular}{lcccccc}
\hline & $(1)$ & $(2)$ & $(3)$ & \multicolumn{1}{c}{$(4)$} & \multicolumn{1}{c}{$(5)$} & \multicolumn{1}{c}{$(6)$} \\
\hline Constant & $2.622^{* * *}$ & $2.622^{* * *}$ & $2.622^{* * *}$ & $2.622^{* * *}$ & $2.623^{* * *}$ & $2.622^{* * *}$ \\
& {$[0.019]$} & {$[0.019]$} & {$[0.019]$} & {$[0.019]$} & {$[0.019]$} & {$[0.019]$} \\
Observations & 27,669 & 27,669 & 27,669 & 27,669 & 27,669 & 27,669 \\
$\mathrm{R}^{2}$ & 0.73 & 0.73 & 0.73 & 0.73 & 0.73 & 0.74 \\
Adj. $\mathrm{R}^{2}$ & 0.70 & 0.70 & 0.70 & 0.70 & 0.70 & 0.70 \\
\hline
\end{tabular}

Notes: Table 4.6 shows the results from a propensity score weighted regression model using the logarithm of the effective rent per square foot as dependent variable. Robust standard errors clustered for each location cluster in brackets. Significance at the 0.10, 0.05 and 0.01 level is indicated by ${ }^{*}, * *$ and ${ }^{* * *}$ respectively.

Table 4.7 presents the relationship between the various environmental attributes and the transaction price (control variables are omitted from the Table). Similar to the specifications described above, the models in Table 4.7 explain some 68 percent of the variation in transaction price.

Column (1) displays that an Energy Star label commands a 15.1 percent transaction price premium as compared to non-labeled buildings. However, the coefficient on Energy Star vintage indicates that the premium decreases with 5.7 percent for every year the label ages. The average Energy Star labeled building in the transaction sample would therefore command a 9.4 percent transaction price increment. Office buildings with both an Energy Star and LEED certificate - this applies to 27 percent of the certified buildings in the transaction sample - command a transaction price premium of 18.1 percent.

Column (2) shows the relationship between the Energy Star rating level and the sales price for the office buildings in the transaction sample. The premium associated with an Energy Star label increases with 0.12 percent for every one-point increase in the rating. This effect is slightly larger as compared to the results for the rental sample. On average, an Energy Star labeled office building commands a 9 percent price premium with a maximum premium of 12 percent for a building with 100 points. ${ }^{26}$

Column (3) examines the effect of the LEED score on the transaction price. The coefficient on LEED score indicates that a one-point increase in the rating yields a 0.36 percent increase in the transaction price. ${ }^{27}$ This implies that the average LEED certified building with a rating of 55 would sell for 19.8 percent more compared to an otherwise similar office building without a LEED certification; the maximum LEED score observed in the transaction sample of 84 points is associated with a 30.2 percent premium, but we do not observe many of such buildings in our sample. An Energy Star label in addition to a LEED certification further increases the transaction price premium with 10 percent.

Column (4) corroborates the findings for the rental sample that the transaction price increment for LEED for newly constructed (New Construction or Core and Shell) buildings differs significantly from the price increment for LEED for Existing Buildings. The premium for LEED

\footnotetext{
${ }^{26}$ In an alternative specification, Energy Stare rating squared is included to examine a possible nonlinear relationship between the transaction price increment and the Energy Star rating. The coefficient on this variable is not significant, although the negative coefficient points in the expected direction.

${ }^{27}$ In an alternative specification, LEED score squared is included as well to examine a possible nonlinear relationship between the transaction price increment and the LEED score. The coefficient on this variable is not significant, although the negative coefficient points in the expected direction.
} 
for Core and Shell is highest at 29.3 percent, followed by a positive and significant premium of 17.1 percent for LEED for Existing Buildings. Given that 78 percent of the buildings certified under this program have an Energy Star label, this yields an additional premium of 10.4 percent. Buildings certified under the New Construction program do not command a price premium as compared to buildings without a LEED certificate, although the positive coefficient points in the expected direction.

Table 4.7: Certification Characteristics and Transaction Prices

\begin{tabular}{|c|c|c|c|c|c|c|}
\hline & $(1)$ & $(2)$ & (3) & $(4)$ & (5) & (6) \\
\hline Energy star & $0.151^{* * *}$ & & $0.100^{* * *}$ & $0.104^{* * *}$ & $0.100^{* * *}$ & $0.100^{* * *}$ \\
\hline (1=yes) & {$[0.034]$} & & {$[0.028]$} & {$[0.028]$} & {$[0.028]$} & {$[0.027]$} \\
\hline $\begin{array}{l}\text { Energy star vintage } \\
\text { (years) }\end{array}$ & $\begin{array}{c}-0.057^{* * *} \\
{[0.015]}\end{array}$ & & & & & \\
\hline $\begin{array}{l}\text { Energy star rating } \\
(0-10)\end{array}$ & & $\begin{array}{l}0.012^{* * *} \\
{[0.003]}\end{array}$ & & & & \\
\hline LEED & $0.181^{* * *}$ & $0.189^{* * *}$ & & & & \\
\hline (1=yes) & {$[0.049]$} & {$[0.049]$} & & & & \\
\hline $\begin{array}{l}\text { LEED score } \\
(0-10)\end{array}$ & & & $\begin{array}{l}0.036^{* * *} \\
{[0.008]}\end{array}$ & & & \\
\hline \multicolumn{7}{|l|}{ LEED program (1=yes) } \\
\hline Core and shell & & & & $\begin{array}{l}0.293^{* * *} \\
{[0.102]}\end{array}$ & & \\
\hline New construction & & & & $\begin{array}{c}0.103 \\
{[0.177]}\end{array}$ & & \\
\hline Existing buildings & & & & $\begin{array}{l}0.171^{* * *} \\
{[0.054]}\end{array}$ & & \\
\hline \multicolumn{7}{|l|}{ LEED certification level ( $1=y e s)$} \\
\hline Certified & & & & & $\begin{array}{c}0.040 \\
{[0.122]}\end{array}$ & \\
\hline Silver & & & & & $\begin{array}{r}0.158^{*} \\
{[0.092]}\end{array}$ & \\
\hline Gold & & & & & $\begin{array}{l}0.185^{* * *} \\
{[0.061]}\end{array}$ & \\
\hline Platinum & & & & & $\begin{array}{l}0.486^{* * *} \\
{[0.122]}\end{array}$ & \\
\hline \multicolumn{7}{|l|}{ LEED rating by category $(0-10)$} \\
\hline Energy and atmosphere & & & & & & $\begin{array}{c}-0.012 \\
{[0.025]}\end{array}$ \\
\hline Innovative design & & & & & & $\begin{array}{r}-0.014 \\
{[0.018]}\end{array}$ \\
\hline Indoor environmental quality & & & & & & $\begin{array}{c}0.042 \\
{[0.026]}\end{array}$ \\
\hline Materials and resources & & & & & & $\begin{array}{r}-0.013 \\
{[0.025]}\end{array}$ \\
\hline Sustainable sites & & & & & & $\begin{array}{c}0.006 \\
{[0.022]}\end{array}$ \\
\hline Water efficiency & & & & & & $\begin{array}{c}0.028 \\
{[0.024]}\end{array}$ \\
\hline
\end{tabular}


Table 4.7 (continued from previous page)

\begin{tabular}{lcccccc}
\hline & $(1)$ & $(2)$ & $(3)$ & $(4)$ & $(5)$ & $(6)$ \\
\hline Building characteristics & yes & yes & yes & yes & yes & yes \\
Location clusters & yes & yes & yes & yes & yes & yes \\
Quarter-year effects & yes & yes & yes & yes & yes & yes \\
Constant & $4.285^{* * *}$ & $4.280^{* * *}$ & $4.279^{* * *}$ & $4.280^{* * *}$ & $4.278^{* * *}$ & $4.279^{* * *}$ \\
& {$[0.140]$} & {$[0.141]$} & {$[0.141]$} & {$[0.141]$} & {$[0.141]$} & {$[0.141]$} \\
Observations & 11,567 & 11,567 & 11,567 & 11,567 & 11,567 & 11,567 \\
$\mathrm{R}^{2}$ & 0.71 & 0.71 & 0.71 & 0.71 & 0.71 & 0.71 \\
Adj. $\mathrm{R}^{2}$ & 0.68 & 0.68 & 0.68 & 0.68 & 0.68 & 0.68 \\
\hline
\end{tabular}

Notes: Table 4.7 shows the results from a propensity score weighted regression model using the logarithm of the transaction price per square foot as dependent variable. Robust standard errors clustered for each location cluster in brackets. Significance at the 0.10, 0.05 and 0.01 level is indicated by *** and ${ }^{* * *}$ respectively.

Column (5) shows the results for the different LEED rating levels. Contrasting the findings for the rental sample, a higher LEED certification level is associated with a higher transaction price. Whereas buildings that are LEED Certified do not sell for more, buildings with the certification level Silver or Gold sell for 15.8 and 18.5 percent more, respectively. The premium for buildings with a LEED Platinum certificate is 48.6 percent. We note that the number of LEED Platinum buildings in our transaction sample is quite small, it is therefore possible that we observe a subset of so-called trophy buildings. ${ }^{28}$

Column (6) documents the impact of the different LEED credit categories on the transaction price. In contrast to our earlier findings, none of the specific categories indicate a significant relationship with the transaction price of the office buildings in our sample. The small number of LEED observations in the transaction sample might explain part of these results, or the market is ignorant towards the underlying environmental performance details.

\subsection{Conclusion}

The durable building stock in the United States is a major consumer of energy and other natural resources. The Energy Information Agency predicts that between the years 2012 and 2040, residential electricity consumption will increase by 21 percent, and commercial electricity consumption will also increase by 21 percent. ${ }^{29}$ This increased consumption will have significant greenhouse gas externality consequences since a large share of electricity is generated using fossil fuels such as coal and natural gas.

An ongoing policy agenda seeks to identify cost-effective climate change mitigation and adaptation strategies (Konrad and M, 2014; Stern, 2008). Environmental certification programs are a means to reduce information asymmetry, which otherwise may prevent the market from pricing the energy performance of buildings. In different industries, certification and disclosure programs have proven to be effective tools for information provision.

\footnotetext{
${ }^{28}$ Inspecting the individual building characteristics for these buildings confirms the notion that these are very high quality assets. Examples of such assets are: 101 California Street in San Francisco, the LA Tower at 400 South Hope Street in Los Angeles or the Hyatt Center in Chicago.

${ }^{29}$ See pages IF-46, MT-7 and MT-9 of the U.S. Energy Information Administration's Annual Energy Outlook 2014 With Projections to 2040, http: //www. eia.gov/forecasts/AE0/pdf/0383(2014) .pdf.
} 
Our work highlights the importance of focusing on commercial buildings, and the relevance of voluntary certification programs. The two most important national programs verifying the environmental attributes of buildings are EPA's Energy Star and USGBC's LEED programs. We document that the adoption of these environmental certification schemes has increased strongly over the last decade. By 2014, almost 40 percent of the square footage in the 30 largest U.S. office markets had been certified under the Energy Star or LEED program. Some markets have even seemed to reach a saturation point, such as Minneapolis/St. Paul with an environmental certification adoption of 77 percent (measured by square footage).

With environmental building certification reaching significant adoption levels, the implications for commercial real estate investors are becoming more important. Prior research has evaluated the financial performance of green buildings when this market was still nascent (see for example, Eichholtz et al., 2010, 2013; Fuerst and McAllister, 2011), but the recent growth of voluntary adoption of environmental building certification, yields the need for further research and insight into the financial performance of environmentally certified assets.

Using a longitudinal dataset of 25,690 buildings in the largest CBSAs, we construct a set of rent indices, analyzing the annual growth in total net asking rent and effective rent of environmentally certified and non-certified commercial office buildings since 2004. The findings of the repeated rent models show that the relationship between rental performance and environmental certification is dynamic, and the impact of environmental certification has changed significantly over time. Although statistically hard to assess, it seems that pre-crisis, environmentally certified buildings enjoyed stronger rental and occupancy growth, which has reversed post-crisis non-certified buildings had a stronger rebound in the 2009-2014 period. However, the rental, occupancy and pricing levels of environmentally certified buildings remain significantly higher than for non-certified buildings. A propensity-weighted cross-sectional analysis shows a consistent rent and transaction price increment for Energy Star labeled and LEED certified office buildings.

Using a performance attribution analysis, we further disentangle the value determinants of environmental building certification. We document that the energy and environmental performance of commercial assets is more valuable in locations with more extreme climates. Surprisingly, in combination with the impact of the local climate, electricity prices are negatively associated with the marginal impact of environmental certification, although the documented effect is small. The relationship between environmental certification and location quality, as measured by the so-called "Walkscore," is ambiguous. The assets in the rental sample show a negative relationship, whereas the results for the transaction sample indicate a positive relationship. This may be related to certification premiums now commanded primarily in less walkable areas. Moreover, the marginal transaction premium for environmentally certified office buildings increases with building size.

With respect to the specific certification characteristics, we document that Energy Star labeled buildings consistently command a rent premium compared to non-certified buildings. Importantly, it is not just the label that matters: the marginal rent increases with 0.04 percent for each one-point increase in the rating of Energy Star certified buildings, and vintage matters. For LEED certified office buildings, we document that the marginal value of certification is higher for newly constructed buildings relative to existing buildings with a LEED certificate. The LEED certification level has a limited impact on the effective rent level of an office building; 
the highest marginal impact is achieved by the lowest certification level. The different LEED categories show that Water Efficiency, Materials and Resources, and Sustainable Sites have the largest effect on the effective rent level of the assets in the rental sample. In contrast to the rental sample, the observed transaction price premium is increasing with the LEED certification level. Moreover, the different LEED categories do not have a significant impact on the transaction price. The limited number of certified assets we observe in the transaction sample might partly explain the insignificance of the categories, since the coefficients point in a similar direction as the effects we observe in the rental sample.

The findings in this chapter have some implications for policy makers. Credible energy and sustainability labels provide a relatively low-cost strategy for differentiation in the commercial building stock. If certified office buildings rent or sell for a premium, or have a higher propensity to be leased, this encourages building owners to consider investing in increased energy efficiency. Information on the energy efficiency and sustainability of buildings in the U.S. commercial market is currently provided just for exemplary assets (designated with Energy Star or LEED labels). The mandatory disclosure of such information for the full distribution of the commercial building stock could further the understanding by private firms of the energy efficiency of their (prospective) premises, thereby reducing the information asymmetry that is presumably an important explanation for the energy-efficiency gap (Palmer and Walls, 2014). An effective and cheap market signal may trigger investments in the efficiency of the building stock, with positive externality effects as a result. 


\section{Appendix}

\section{A Main Results for the Attribution Analysis}

Table A.1: Environmental Certification, Building Characteristics, Rent, and Transaction Price

\begin{tabular}{|c|c|c|c|c|c|c|}
\hline & \multicolumn{2}{|c|}{ Average Weighted Rent } & \multicolumn{2}{|c|}{ Effective Rent } & \multicolumn{2}{|c|}{ Transaction Price } \\
\hline & (1) & (2) & (3) & (4) & (5) & (6) \\
\hline \multirow{2}{*}{ Green (1=yes) } & $0.025^{* * *}$ & & $0.052^{* * *}$ & & $0.144^{* * *}$ & \\
\hline & {$[0.005]$} & & {$[0.007]$} & & {$[0.026]$} & \\
\hline \multirow[t]{2}{*}{ Energy star (1=yes) } & & $0.015^{* * *}$ & & $0.038^{* * *}$ & & $0.100^{* * *}$ \\
\hline & & {$[0.006]$} & & {$[0.008]$} & & {$[0.028]$} \\
\hline \multirow[t]{2}{*}{ LEED (1=yes) } & & $0.023^{* *}$ & & $0.034^{* *}$ & & $0.189^{* * *}$ \\
\hline & & {$[0.010]$} & & {$[0.014]$} & & {$[0.049]$} \\
\hline Log size & $0.044^{* * *}$ & $0.044^{* * *}$ & $0.070^{* * *}$ & $0.071^{* * *}$ & $-0.101^{* * *}$ & $-0.101^{* * *}$ \\
\hline (thousand square feet) & {$[0.003]$} & {$[0.003]$} & {$[0.004]$} & {$[0.004]$} & {$[0.015]$} & {$[0.015]$} \\
\hline Occupancy rate & $0.048^{* * *}$ & $0.049^{* * *}$ & & & & \\
\hline$(0-1)$ & {$[0.012]$} & {$[0.012]$} & & & & \\
\hline \multicolumn{7}{|l|}{ Building class (1=yes) } \\
\hline \multirow[t]{2}{*}{ Class A } & $0.132^{* * *}$ & $0.132^{* * *}$ & $0.134^{* * *}$ & $0.134^{* * *}$ & $0.534^{* * *}$ & $=0.536^{* * *}$ \\
\hline & {$[0.009]$} & {$[0.009]$} & {$[0.011]$} & {$[0.011]$} & {$[0.052]$} & {$[0.052]$} \\
\hline \multirow[t]{2}{*}{ Class B } & $0.042^{* * *}$ & $0.042^{* * *}$ & $0.052^{* * *}$ & $0.052^{* * *}$ & $0.227^{* * *}$ & $0.230^{* * *}$ \\
\hline & {$[0.008]$} & {$[0.008]$} & {$[0.009]$} & {$[0.009]$} & {$[0.038]$} & {$[0.038]$} \\
\hline \multicolumn{7}{|l|}{ Number of Stories (1=yes) } \\
\hline \multirow[t]{2}{*}{ Medium (10-20) } & $-0.018^{* * *}$ & $-0.018^{* * *}$ & -0.011 & -0.012 & -0.021 & -0.025 \\
\hline & {$[0.005]$} & {$[0.005]$} & {$[0.008]$} & {$[0.008]$} & {$[0.033]$} & {$[0.033]$} \\
\hline \multirow[t]{2}{*}{$\operatorname{High}(>20)$} & $-0.026^{* * *}$ & $-0.027^{* * *}$ & $-0.024^{* *}$ & $-0.025^{* *}$ & $0.092^{* *}$ & $0.083^{* *}$ \\
\hline & {$[0.008]$} & {$[0.008]$} & {$[0.011]$} & {$[0.011]$} & {$[0.041]$} & {$[0.040]$} \\
\hline \multicolumn{7}{|l|}{ Age (1=yes) } \\
\hline \multirow[t]{2}{*}{$\leq 10$ years } & $0.091^{* * *}$ & $0.091^{* * *}$ & $0.098^{* * *}$ & $0.098^{* * *}$ & $0.381^{* * *}$ & $0.379^{* * *}$ \\
\hline & {$[0.008]$} & {$[0.008]$} & {$[0.009]$} & {$[0.009]$} & {$[0.033]$} & {$[0.033]$} \\
\hline \multirow[t]{2}{*}{11 to 20 years } & $0.056^{* * *}$ & $0.056^{* * *}$ & $0.088^{* * *}$ & $0.087^{* * *}$ & $0.231^{* * *}$ & $0.235^{* * *}$ \\
\hline & {$[0.008]$} & {$[0.008]$} & {$[0.009]$} & {$[0.009]$} & {$[0.028]$} & {$[0.028]$} \\
\hline \multirow[t]{2}{*}{21 to 30 years } & $0.059^{* * *}$ & $0.059^{* * *}$ & $0.056^{* * *}$ & $0.056^{* * *}$ & $0.205^{* * *}$ & $\quad 0.207^{* * *}$ \\
\hline & {$[0.007]$} & {$[0.007]$} & {$[0.008]$} & {$[0.008]$} & {$[0.030]$} & {$[0.030]$} \\
\hline \multirow[t]{2}{*}{31 to 40 years } & 0.010 & 0.010 & $0.019 * *$ & $0.019^{*}$ & $0.314^{* * *}$ & $0.315^{* * *}$ \\
\hline & {$[0.008]$} & {$[0.008]$} & {$[0.010]$} & {$[0.010]$} & {$[0.045]$} & {$[0.045]$} \\
\hline \multirow[t]{2}{*}{41 to 50 years } & $0.054^{* * *}$ & $0.054^{* * *}$ & $0.084^{* * *}$ & $0.084^{* * *}$ & $0.231^{* * *}$ & $0.233^{* * *}$ \\
\hline & {$[0.010]$} & {$[0.010]$} & {$[0.012]$} & {$[0.012]$} & {$[0.060]$} & {$[0.060]$} \\
\hline \multirow[t]{2}{*}{ On-site amenities (1=yes) } & 0.006 & 0.006 & $0.012^{*}$ & $0.012^{*}$ & $0.105^{* * *}$ & $0.106^{* * *}$ \\
\hline & {$[0.004]$} & {$[0.004]$} & {$[0.006]$} & {$[0.006]$} & {$[0.025]$} & {$[0.026]$} \\
\hline \multirow[t]{2}{*}{ Walk score $(0-10)$} & $-0.010^{* * *}$ & $-0.010^{* * *}$ & $-0.010^{*}$ & $-0.010^{*}$ & -0.014 & -0.009 \\
\hline & {$[0.004]$} & {$[0.004]$} & {$[0.005]$} & {$[0.005]$} & {$[0.019]$} & {$[0.020]$} \\
\hline Location clusters & yes & yes & yes & yes & yes & yes \\
\hline Quarter-year effects & no & no & no & no & yes & yes \\
\hline
\end{tabular}


Table A.1 (continued from previous page)

\begin{tabular}{lcccccc}
\hline & \multicolumn{2}{c}{ Average Weighted Rent } & \multicolumn{2}{c}{ Effective Rent } & \multicolumn{2}{c}{ Transaction Price } \\
& $(1)$ & $(2)$ & $(3)$ & $(4)$ & $(5)$ & $(6)$ \\
\hline Constant & $2.977^{* * *}$ & $2.977^{* * *}$ & $2.686^{* * *}$ & $2.686^{* * *}$ & $4.432^{* * *}$ & $4.383^{* * *}$ \\
& {$[0.035]$} & {$[0.035]$} & {$[0.049]$} & {$[0.049]$} & {$[0.223]$} & {$[0.228]$} \\
Observations & 27,669 & 27,669 & 27,669 & 27,669 & 11,567 & 11,567 \\
$\mathrm{R}^{2}$ & 0.80 & 0.80 & 0.73 & 0.73 & 0.71 & 0.71 \\
Adj. $\mathrm{R}^{2}$ & 0.78 & 0.78 & 0.70 & 0.70 & 0.68 & 0.68 \\
\hline
\end{tabular}

Notes: Table A.1 shows the results from a propensity score weighted regression model using the logarithm of the average weighted rent, effective rent, or transaction price per square foot as dependent variable. Robust standard errors clustered for each location cluster in brackets. Significance at the $0.10,0.05$ and 0.01 level is indicated by *** and ${ }^{* * *}$ respectively. 



\section{Chapter 5}

\section{Environmental Performance and the Cost of Capital: Evidence from Commercial Mortgages and REIT Bonds*}

\subsection{Introduction}

As witnessed by the recent attention to the COP21 meetings in Paris, there is an increasing societal focus on environmental issues, most importantly the carbon externality from energy consumption, and its effects on climate change. This focus has led to global corporate action on environmental sustainability - a major aspect of the broader corporate social responsibility (CSR). While some firms, such as Unilever and Patagonia, have made CSR core to their business strategy, other firms invest in CSR just to be compliant with regulation. Such differentiation leads to important questions about the relationship between firms' environmental performance and their financial performance, the outcome of which is of interest to investors, corporations, and policy makers.

There is a significant body of academic research investigating this relationship, typically focusing on broad measures of CSR. Margolis et al. (2007) survey the related literature for the period over the 1972 to 2007 period and conclude that environmental performance and other elements of CSR tend to have a positive impact on financial performance. More recently, Servaes and Tamayo (2013) paint a more nuanced picture, providing evidence that such positive relationship only holds for companies with high customer awareness. Eccles et al. (2014) document that companies voluntarily adopting sustainability policies subsequently perform better financially, both on the stock market as well as measured by accounting metrics.

Even though there seems to be some consensus regarding the impact of environmental performance on financial performance, it is rather challenging to disentangle the mechanism by which CSR affects corporate performance. One such mechanism is that CSR or environmental performance may lead to an improved corporate image and an enhanced reputation, which

${ }^{*}$ This chapter is co-authored with Piet Eichholtz (Maastricht University), Nils Kok (Maastricht University, and Erkan Yönder (Özyeğin University). 
could benefit companies on the labor, goods, and capital markets (Turban and Greening, 1997). Another mechanism is more direct, and relates to efficient use of resources, generating less pollution and waste, and an overall increase in organizational effectiveness (Sharfman and Fernando, 2008).

While CSR may directly affect the operations of a firm, another mechanism to influence financial performance is through the cost of capital needed to finance operations. It has been argued that CSR-related investments may lead to a reduction in operational risk (Albuquerque et al., 2014; An and Pivo, 2015; Kytle and Hamilton, 2005), which could result in easier access to capital or a reduced cost of capital.

The literature investigating the impact of CSR and environmental practices on the cost of debt is quite limited, with the early literature documenting no discernable effect or even higher spreads for better CSR performance. For example, D'Antonio et al. (1997) investigate the performance of socially screened bond mutual funds, but find no relationship between CSR and yield differences on a risk-adjusted basis. Sharfman and Fernando (2008) conclude that the debt capacity for companies with a superior environmental performance is higher, but that their cost of debt is higher as well.

More recent papers contrast the early findings: Bauer and Hann (2010) document strong evidence that environmental performance is associated with reduced bond spreads. Goss and Roberts (2011) show that companies with a lower score from KLD - a CSR rating agency have higher spreads on their bank loans. However, investments in CSR are only rewarded if the borrower has a high credit rating. Attig et al. (2013) find that bonds issued by firms with strong CSR performance have better credit ratings, which usually leads to better financing terms. More recently, Chava (2014) analyzes the cost of equity and bank loans for companies with and without environmental concerns. The results show that firms without these concerns pay lower interest rates, and that investors in their stocks demand lower returns. Oikonomou et al. (2014) document that strong CSR performance is associated with better credit ratings and lower cost of debt for firms in a broad range of industries.

While recent studies are directionally consistent in findings, questions remain about the mechanism of the documented effects. There are also some concerns about endogeneity issues that tend to hamper research in related fields: the direction of causality between environmental performance and cost of capital is hard to identify, due to potentially confounding factors. For example, firm's cost of capital may be affected by the quality of its management, which may also affect the firm's environmental considerations.

This chapter addresses some of the shortcomings in the literature, investigating the effect of corporate environmental performance on the cost of debt, not just at the company level, but also at the level of individual assets and the loans financing those assets. We examine the real estate sector, which provides a unique combination of companies whose sole activity is the management of a real estate portfolio - Real Estate Investment Trusts, or REITs — and assets which are unequivocally related to the debt that underwrites the assets - corporate bonds and mortgages. We analyze the spread on bonds issued by REITs and on the mortgages that are collateralized by individual buildings, a combination of analyses that is possible for REITs only. The analysis at the individual asset level examines different assets owned by the same firm and the mortgages collateralizing those assets, implying that firm characteristics cannot explain the cross-sectional effects, reducing endogeneity concerns. 
We also specifically address the issue of endogeneity in the corporate-level analysis. First, we employ a robust set of instruments in a two-stage model, using a weighted local measure of environmental certification for each REIT portfolio, as well as the lagged weights of environmental certification. In addition, we estimate a difference-in-difference analysis on REIT corporate bond spreads after issuance. This time-series analysis allows us to investigate the effects of changes in REIT environmental performance on corporate bond spreads. The difference-in-difference approach aims to isolate the impact of a change in the share of environmentally certified buildings in a portfolio by a given firm on the change in bond spreads, eliminating any unobservable fixed effects.

In addition to the methodological advantages offered by analyzing commercial real estate, the sector plays a key role in the production — and therefore also the reduction — of greenhouse gas emissions. For instance, the Energy Information Administration (EIA) reports that buildings accounted for 41 percent of total US energy consumption in $2014 .^{2}$ Moreover, the EIA expects the energy consumption in the commercial building sector to increase by 23 percent until $2040 .^{3}$ As the regulatory response to increasing energy efficiency in the real estate sector is mostly focused on market-based solutions, for example through improving information transparency, understanding the broader financial implications of investments in the energy efficiency and environmental performance of real estate is important for investors and policy makers alike.

As a proxy for the energy and environmental efficiency of buildings, we investigate the mortgage spreads of assets that are environmentally certified by LEED or Energy Star - both are widely accepted measures of environmental building performance. Controlling for a broad set of mortgage and asset characteristics, we test how the capital market evaluates the environmental performance of collateral underlying financial products. The results show that the spreads of mortgages on environmentally certified buildings are significantly lower than those on conventional buildings, with the difference varying between 35 and 36 basis points, depending on the specification. This translates into a reduction of about USD 210,000 in the annual interest payment of an average commercial mortgage in the sample. The heterogeneity in a building's environmental performance is also reflected in mortgage spreads. A detailed analysis of buildings with different LEED labels shows that the decline in the interest expense is largest for "Platinum" labeled buildings, with a reduction in interest payments of some USD 410,000.

At the corporate level, we assess the fraction of a REIT portfolio that is environmentally certified — as measured by LEED and Energy Star certification — and then evaluate the impact on REIT corporate bond spreads. Using a two-stage least square analysis that explicitly controls for endogeneity, we document that companies with a higher share of energy efficient and environmentally certified assets have significantly lower bond spreads, even though the effect is economically quite small. A one-standard deviation increase in the share of environmentally certified buildings decreases the corporate bond spread at issuance by about 11 basis points. This translates into a difference in interest payment of USD 109,000 for the average corporate bond in our sample. Importantly, the difference-in-difference analysis shows a 17 basis point decline in bond spread when a REIT increases its share of environmentally certified buildings by one percent.

\footnotetext{
${ }^{2}$ Energy consumption by sector for 2014 retrieved from: http://www . eia.gov/totalenergy/data/ monthly.

${ }^{3}$ EIA Annual Energy Outlook 2014. For details, please visit http://www . eia.gov/forecasts/aeo.
} 
The results in this chapter add to the academic evidence on the economic implications of environmental performance in general, and specifically for real estate. There is strong evidence that environmentally certified buildings have a higher and more stable occupancy rate, and higher marginal rents and transaction prices (Eichholtz et al., 2010, 2013; Fuerst and McAllister, 2011), and that REITs with a higher share of environmentally certified buildings have stronger operational performance (Eichholtz et al., 2012a). These effects provide evidence of the market efficiently capitalizing environmental performance. The reflection of environmental performance in the cost of capital of real estate assets and firms provides another market-based nudge for building owners and investors adopting more energy efficient investment practices in the commercial real estate market.

The remainder of the chapter is organized as follows: we first discuss the concept of "green" buildings, providing an overview of the literature concerning their financial performance. Section three presents and describes the data employed in the analysis and section four outlines the method. Section five discusses the results, and the chapter ends with conclusions and implications.

\subsection{Environmental Performance and Real Estate Investments}

It has been well documented that the commercial and residential real estate sector can play a pivotal role in the reduction of global energy consumption, given its significant footprint, and the wide array of seemingly profitable energy efficiency measures and technologies at its disposal (Enkvist et al., 2007; Kahn et al., 2014). The real estate industry has responded to the societal debate and regulatory response in different ways. One particularly important development is the establishment of environmental certification programs, both at the building and at the portfolio level. Information provision about the relative performance of assets and firms, comparable to the miles-per-gallon (MPG) sticker on cars or hygiene scorecards in restaurants, may lead to increased consumer awareness, and thus increased market efficiency (Jin and Leslie, 2009; Sexton and Sexton, 2014).

In the U.S., the two leading certification programs at the asset level are LEED and Energy Star, which have been developed by the U.S. Green Building Council (USGBC) and the U.S. Environmental Protection Agency (EPA), respectively. As of November 2015, the U.S. real estate market counted 18,167 commercial buildings with a LEED certificate and 26,938 commercial buildings with an Energy Star label. ${ }^{4}$

The environmental performance of the built environment is increasingly relevant to a substantial part of the commercial real estate market, as the diffusion of the two certification programs has spread rapidly over the past decade. At the end of 2005, less than six percent of the building stock (by square footage) in the 30 largest office markets in the U.S. had been certified under the LEED and Energy Star program, but this increased to almost 40 percent at

\footnotetext{
${ }^{4}$ The Green Building Information Gateway provides information on the number of buildings certified under the LEED program by the USGBC: http://www.gbig.org/search/advanced. The number of commercial buildings labeled by the EPA is retrieved from: http://www . energystar.gov/index.cfm? fuseaction=labeled_buildings. locator.
} 
the end of 2014 (Holtermans et al., 2015). Moreover, McGraw-Hill Construction estimates that 44 percent of new construction projects in 2012 were "green" and projections suggest that this share will increase to 55 percent by $2016 .^{5}$

Comparable to investments in CSR for a general corporation, an important and lingering question is the extent to which social and environmental benefits of real assets generate economic and financial value for investors. Indeed, a survey by Pivo (2008) shows that REIT managers give more weight to "concern for risk and return" and "opportunities to outperform" than to "moral responsibility" when they consider sustainability investments in assets. However, this early survey also shows that managers' main concern lies in the lack of information on the financial performance of environmentally certified buildings.

A growing body of literature aims to assess the economic implications of energy efficiency and environmental performance of buildings. Capitalizing on the widespread adoption of environmental certification, the literature consistently shows that certified commercial buildings generate significantly higher marginal rents and increased transaction prices as compared to conventional, but otherwise comparable buildings (Chegut et al., 2014; Eichholtz et al., 2010, 2013; Fuerst and McAllister, 2011). Importantly, these studies also find higher and more stable occupancy rates for environmentally certified buildings, which is the key yardstick for systematic risk at the asset level. For residential homes, Brounen and Kok (2011) document not just higher values for more efficient homes, but also a significantly shorter time on the market when dwellings are on sale.

Analyzing the implications of investments in environmental performance at the corporate level, Eichholtz et al. (2012a) document that REITs owning a larger fraction of environmentally certified buildings display enhanced operating performance, as measured by return on assets (ROA), return on equity (ROE) and funds from operations (FFO). A four-factor model shows that REITs with larger fractions of environmentally certified space also exhibit significantly lower systematic risk (beta).

It is important to note that besides positive rent and value effects, the literature also consistently shows a negative relationship between environmental performance and risk: environmentally certified real estate assets tend to have higher and more stable occupancy rates, are easier to sell, and have lower systematic risk. A recent paper by An and Pivo (2015) reiterates these results, documenting that commercial mortgages collateralized by environmentally certified buildings have a lower default risk. This finding is particularly important for the purpose of this chapter, since lower default risk may translate into a lower required risk premium, and potentially also into a lower cost of debt.

\subsection{Data}

\subsubsection{REITs and Environmentally Certified Buildings}

We identify LEED and Energy Star labeled buildings in the portfolios of REITs by matching the addresses of REIT-owned assets provided by SNL Real Estate with LEED and Energy Star data provided by the U.S. Green Building Council (USGBC) and the Environmental Protection

\footnotetext{
${ }^{5}$ McGraw-Hill Construction Green Building Outlook 2013.
} 
Agency (EPA). Using GIS techniques, we transform all addresses into longitudes and latitudes, which enables us to geographically map the different datasets, identifying matching assets.

Figure 5.1 presents the time series of the average overall share of environmentally certified space (by square footage) for the sample of REITs, as well as the LEED and Energy Star shares. Analogous to the green building adoption rates documented by Holtermans et al. (2015), the share of environmentally certified buildings is close to zero around 2006, but a continuing upward trend can be observed since that year. In 2014, the average share of environmentally certified buildings reached almost 5 percent of the total square footage of assets in REIT portfolios. The LEED and Energy Star shares show a comparable upward trend. In 2014, the cumulative Energy Star share slightly exceeded the cumulative LEED share and represented almost 4 percent of the total square footage of REIT assets.

\section{Figure 5.1: Portfolio Weights of Environmental Certification over Time}

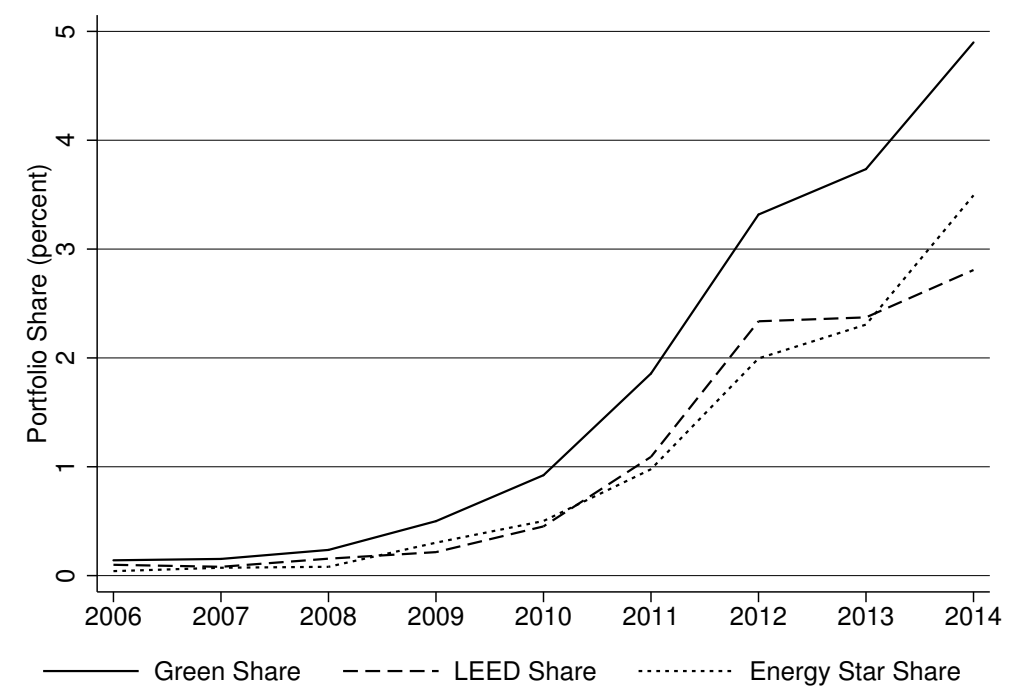

Notes: The figure displays the average share of environmentally certified buildings in REIT portfolios over time. The solid line depicts the share of buildings in REIT portfolios with an Energy Star label, LEED certification or both. The dashed and dotted lines represent the share of buildings in REIT portfolios that are certified under the LEED or Energy Star program, respectively.

Figure 5.2 shows the total share of environmentally certified buildings for all REIT-owned assets in the U.S. (in square footage), measured by Core Based Statistical Area (CBSA) for the years 2006, 2010 and 2014. We observe a clear trend of an increasing share of environmental certification of REIT assets over time. The average share of environmentally certified assets in REIT portfolios in each CBSA increased from 2.7 percent in 2006 to 8.2 percent in $2014 .^{6}$ Moreover, not only the share of assets with an Energy Star or LEED certification increases over time, but the geographical coverage also increases substantially. In 2006, REITs owned environmentally certified assets in just 42 different CBSAs, this number increased to 224 CBSAs in 2014 (out of a total of 929 CBSAs in the U.S.).

\footnotetext{
${ }^{6}$ This excludes CBSAs with a share of environmentally certified assets of zero.
} 
Figure 5.2: Environmental Certification of REIT-Owned Assets by CBSA

Panel A: Share of Environmentally Certified Buildings in 2006 (sq. ft.)

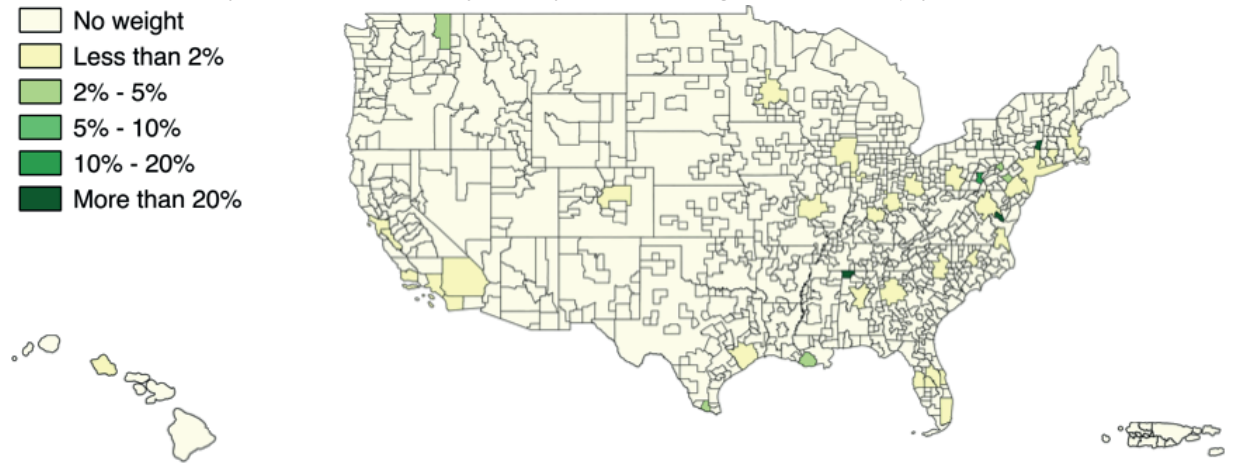

Panel B: Share of Environmentally Certified Buildings in 2010 (sq. ft.)
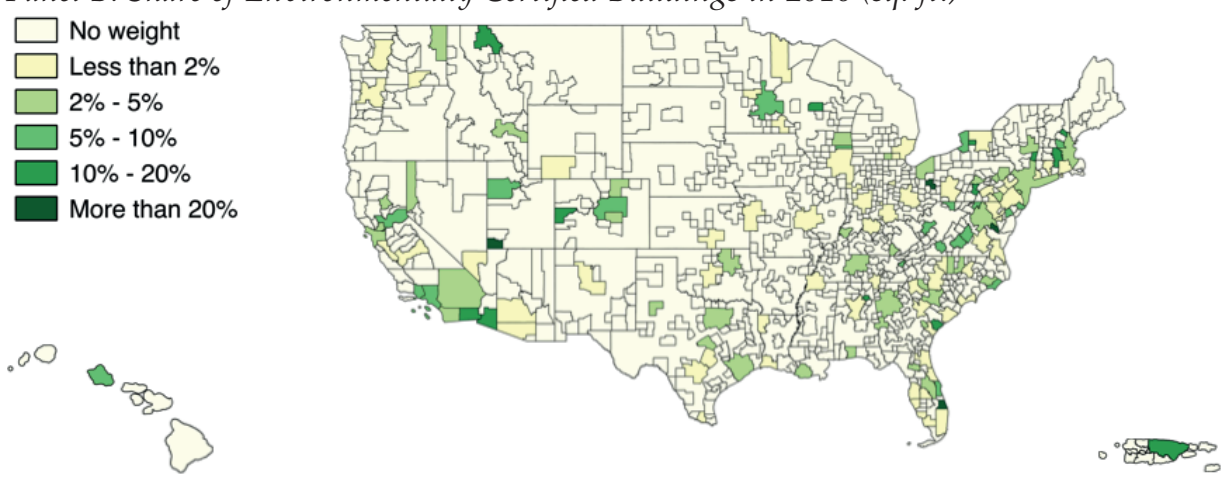

Panel C: Share of Environmentally Certified Buildings in 2014 (sq. ft.)
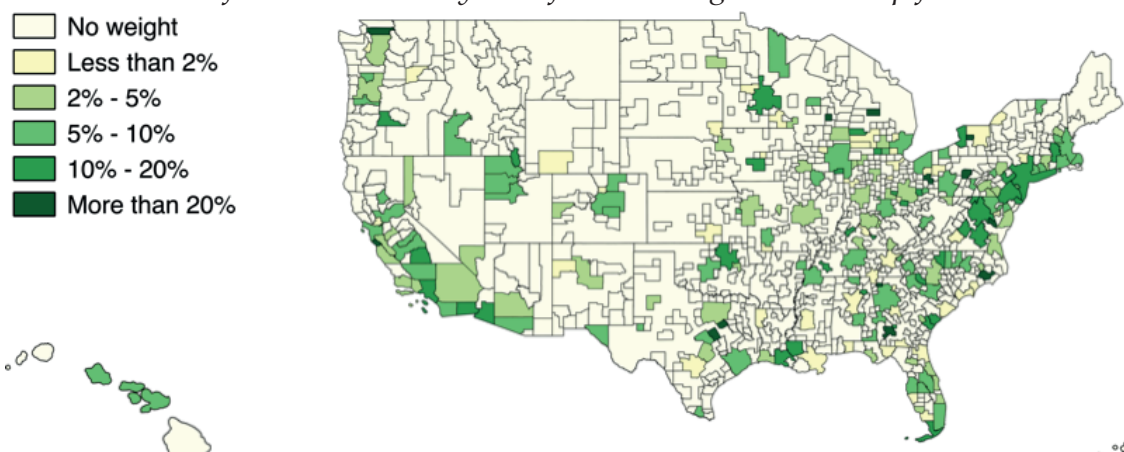

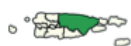

Notes: The share of environmentally certified buildings is calculated by Core Based Statistical Area (CBSA) and based on the total of square footage of certified buildings relative to the total square footage of assets owned by REITs in the CBSA. Hawaii, Puerto Rico and the U.S. Virgin Islands are enlarged for visibility. The state of Alaska is included in the estimation as well, but since the share of environmentally certified buildings in Alaska and its corresponding CBSA, Anchorage, is consistently zero, it is omitted from the figure. 
As compared to the mean of 2.7 percent, the median share of environmentally certified assets by square footage was a mere 0.3 percent in 2006. This increases to a median share of 2.5 percent and 5.5 percent in 2010 and 2014, respectively. The large difference between the mean and median shares indicates a large variation across CBSAs. For example, in 2014, the share of environmentally certified assets across CBSAs varies from 0.02 percent to more than 93 percent. Among the CBSAs, Minneapolis-St. Paul-Bloomington, Chicago-Naperville-Elgin, and Atlanta-Sandy Springs-Roswell show the largest increase in the share of environmentally certified assets over time. This is in line with findings documented by Holtermans et al. (2015).

\subsubsection{REITs and Commercial Mortgages}

The SNL Real Estate database is our main source of data, and contains 211 REITs for which we have complete information on individual asset holdings. SNL provides detailed financial information on the assets owned by U.S. REITs, including encumbrance data for each building in every year, provided that there is a commercial mortgage collateralized by these assets in a REIT portfolio. SNL also provides the value of the encumbrance (the principal value of the debt), the interest rate, the maturity date, a dummy variable indicating whether it is a fixed rate contract, and a "cross-collateralization" dummy indicating whether the debt contract is cross-collateralized by other assets. SNL also provides information on building characteristics, such as the address of the building, the asset type and the age of the building.

The mortgage spread is calculated by subtracting the Treasury rate with the same or closest maturity from the mortgage rate. Time to maturity is calculated by the difference between the year of maturity and the derived year of origination. ${ }^{7}$ Some commercial mortgage contracts are collateralized by multiple assets. First, we determine for each debt contract which assets are combined, by grouping the debt contracts with exactly the same contractual terms by each year. ${ }^{8}$ We then calculate the loan to value (LTV) ratio by dividing the encumbrance value by the total book value of the buildings collateralizing the corresponding contract in the year of origination.

Panel A of Table 5.1 presents the descriptive statistics for REIT mortgages and the buildings underlying these contracts. Our sample covers the period from 2006 to 2014. It includes 4,553 buildings owned by 143 REITs collateralizing 3,303 REIT mortgages, 177 of which are collateralized by Energy Star or LEED-certified buildings. ${ }^{9}$ The average spread is 300 basis points for mortgages collateralized by environmentally certified buildings and 287 basis points for those mortgages collateralized by unlabeled buildings. The average time to maturity is about six years for both samples. The average value of environmentally certified buildings is almost three times as high as the value of non-certified buildings: USD 153 million and USD 44 million,

\footnotetext{
${ }^{7}$ We need the exact date of origination in order to retrieve the Treasury rate corresponding to the date of origination. SNL does not provide the date of origination for the mortgages, but since SNL reports loan data for every year, the year of origination can be derived from the first appearance of the debt contract in the database. Assuming that the day and month of origination are similar to the day and month of maturity, we derive the complete date of origination by combining this information with the year of the first appearance in the database.

${ }^{8}$ We group the contracts collateralized by different buildings by controlling for the same interest rate, the same encumbrance, the same date of maturity and the same company.

${ }^{9} 3.9$ percent of the buildings in our mortgage sample are Energy Star or LEED certified. Specifically, 2.3 percent of the buildings have an Energy Star label and 2.1 percent are certified under the LEED program. These numbers are in line with the numbers reported in Figure 5.1.
} 
respectively. Environmentally certified assets have a somewhat lower LTV (51 percent) as compared to conventional assets (55 percent). Around 79 percent of the assets are financed with fixed rate mortgages. Cross-collateralization is more common among non-certified buildings: 32 percent, against 18 percent for environmentally certified buildings.

In general, high quality buildings are more likely to be certified (Eichholtz et al., 2010). Therefore, the impact of environmental certification can also capture unobservable building characteristics. SNL provides information regarding book value and building age, but to obtain a broader set of building quality characteristics, we match the SNL data with information from CoStar Property. CoStar Property collects data on building rents and transaction prices, combined with an elaborate set of building characteristics. We are able to cross-reference 2,707 buildings from the SNL sample with the CoStar database, 96 of which are Energy Star or LEED certified. For these buildings, we obtain detailed information on the amenities that are present in the building. This includes information on whether the building has been renovated, and its distance to a transit stop. In this subsample, 34 percent of certified buildings are renovated, against 16 percent for the non-certified buildings. Certified buildings are also closer to a transit stop and have a higher likelihood of including amenities.

Table 5.1: Descriptive Statistics (2006-2014)

\begin{tabular}{|c|c|c|c|c|c|c|}
\hline \multirow{2}{*}{\multicolumn{7}{|c|}{$\begin{array}{l}\text { Mean Std. Dev. Obs. } \\
\text { Panel A - Commercial Mortgages and Collateral Assets }\end{array}$}} \\
\hline & & & & & & \\
\hline \multirow{2}{*}{\multicolumn{7}{|c|}{ Building characteristics }} \\
\hline & & & & & & \\
\hline LEED label (1=yes) & - & - & - & 0.54 & 0.50 & 177 \\
\hline Energy Star label (1=yes) & - & - & - & 0.58 & 0.49 & 177 \\
\hline Renovated (1=yes) & 0.16 & 0.37 & 2,611 & 0.34 & 0.48 & 96 \\
\hline On-site amenities (1=yes) & 0.33 & 0.47 & 2,611 & 0.42 & 0.50 & 96 \\
\hline Transit stop (1=yes) & 0.23 & 0.42 & 2,611 & 0.46 & 0.50 & 96 \\
\hline Asset book value (in million dollars) & 44.12 & 96.50 & 4,376 & 152.76 & 253.92 & 177 \\
\hline$\leq 10$ years old $(1=$ yes $)$ & 0.29 & 0.45 & 4,376 & 0.24 & 0.43 & 177 \\
\hline \multicolumn{7}{|l|}{ Mortgage characteristics } \\
\hline Mortgage spread (in bps) & 287.41 & 179.73 & 4,376 & 300.50 & 157.18 & 177 \\
\hline Encumbrance (in million dollars) & 59.12 & 90.67 & 4,376 & 108.76 & 166.82 & 177 \\
\hline LTV (fraction) & 0.55 & 0.24 & 4,376 & 0.51 & 0.26 & 177 \\
\hline Time-to-maturity (in years) & 6.26 & 4.92 & 4,376 & 6.11 & 3.84 & 177 \\
\hline Cross-collateralization ( $1=$ yes) & 0.32 & 0.47 & 4,376 & 0.18 & 0.39 & 177 \\
\hline Fixed rate $(1=$ yes $)$ & 0.79 & 0.41 & 4,376 & 0.81 & 0.39 & 177 \\
\hline \multicolumn{7}{|l|}{ Firm characteristics } \\
\hline Total assets (in billion dollars) & 3.82 & 0.61 & 4,376 & 7.83 & 9.05 & 177 \\
\hline Firm Q & 1.26 & 0.28 & 4,376 & 1.25 & 0.26 & 177 \\
\hline Debt ratio & 0.54 & 0.15 & 4,376 & 0.54 & 0.10 & 177 \\
\hline
\end{tabular}


Table 5.1 (continued from previous page)

\begin{tabular}{lrrr}
\hline Panel B - Corporate Bonds & \multicolumn{3}{c}{ All Bonds } \\
\cline { 2 - 4 } Firm characteristics & 1.99 & 4.64 & 1,690 \\
Green share (in percent) & 1.13 & 3.55 & 1,690 \\
LEED share (in percent) & 1.30 & 3.17 & 1,690 \\
Energy Star share (in percent) & 9.42 & 7.81 & 1,690 \\
Total assets (in billion dollars) & 1.47 & 0.34 & 1,690 \\
Firm Q & 0.53 & 0.10 & 1,690 \\
Debt ratio & & & \\
Bond Characteristics & 299.84 & 399.82 & 1,690 \\
Bond spread (in bps) & 14.31 & 1.10 & 1,690 \\
Moody's rating & 99.37 & 9.21 & 1,690 \\
Debt value (in \$ million) & 6.53 & 4.81 & 1,690 \\
Time-to-maturity (in years) & 0.26 & 0.44 & 1,690 \\
Callable (1=yes) & 0.02 & 0.13 & 1,690 \\
Convertible (1=yes) & &
\end{tabular}

Notes: Table 5.1 shows the descriptive statistics for REIT mortgage data in Panel A and corporate bond data in Panel B. In Panel A, LEED/Energy Star labels show whether a building is LEED/Energy Star certified. Mortgage characteristics include LTV, year to maturity, indicator variables for fixed rate mortgages and whether there is any other asset collateralizing the mortgage. Asset book value and age are also included. The descriptive statistics of mortgage and building characteristics are by building and the descriptive statistics of green share and firm characteristics are by firm-years. In Panel B, LEED (Energy Star) share is the ratio of total square feet of LEED (Energy Star) certified assets to the total square feet of the REIT portfolio in year $t$. Bond characteristics include the debt value, year to maturity and an indicator variable for callable bonds. In both panels, firm characteristics cover the logarithm of total assets, debt-to-asset ratio and firm $\mathrm{Q}$ calculated as the ratio of market value of assets to book value of assets. All of the financial controls are observed at year $\mathrm{t}-1$. The descriptive statistics of bond characteristics are by bond issue and the descriptive statistics of green share and firm characteristics are by firm-years.

\subsubsection{REIT Bonds}

We retrieve corporate bond data for all U.S. equity REITs from FactSet. For each REIT bond, we observe the date of origination, the issue amount, the bond yield, the date of maturity, the bond rating by Moody's and whether the bond is callable and/or convertible. Importantly, we also retrieve secondary market data for the bond yield and credit rating. Following Anderson et al. (2003), we employ the credit rating data by first ranking ratings from low to high, creating a ranking variable that has a value of one for the lowest credit rating, increasing by one for each notch increase in the credit rating. The highest possible value is 23 , corresponding to an AAA+ credit rating. In our sample, the ranking variable for Moody's rating ranges from 8 (B2) to 17 (A2).

We collect constant maturity treasury rates (CMT) from the U.S. Treasury. ${ }^{10}$ Comparable to the mortgage analysis, we calculate the spread of the REIT bonds by subtracting the Treasury

\footnotetext{
${ }^{10}$ For further details, please visit http: //www .treasury . gov/resource-center/data-chart-center/ interest-rates/.
} 
rate with the same or closest time to maturity from the yield of the bond on the REIT bond's origination date, and at the end of every year subsequent to origination if we have secondary market data. We also collect financial characteristics of REITs from SNL for the year preceding the origination: total assets, firm $Q$, and the ratio of total debt to total assets (as well as the interest coverage ratio for the robustness checks).

Merging the SNL data with the secondary market data from FactSet, we obtain a dataset of 234 bonds issued by 44 REITs during the 2006 to 2014 period. In the panel dataset for the secondary market performance analysis, the number of bonds appearing annually varies from 172 to 218. Appendix Figure A.1 shows the annual trends in the number of REITs, the number of bonds and the number of bond originations by year.

Panel B of Table 5.1 presents the descriptive statistics of the REIT corporate bond sample. The average bond spread is 300 basis points, including secondary market data. When we limit the data to the year of origination only, the average spread is 194 basis points. The average time to maturity is 6.53 years and at issuance the mean time to maturity is approximately 10 years. Some two percent and 26 percent of the bonds issued are callable and convertible, respectively. The value of total assets of an average REIT in the bond sample is USD 9.42 billion. The mean debt ratio is 53 percent, while the average firm $\mathrm{Q}$ is 1.47 .

We also present the descriptive statistics on the share of environmentally certified assets and firm characteristics by firm-years: about two percent of a REIT portfolio in the sample is either Energy Star or LEED certified. The share of buildings that have an Energy Star label is 1.3 percent, while the share of buildings with LEED certification is 1.1 percent. The relatively low adoption of environmental certification amongst the buildings in the REIT sample provides an indication that environmental certification still plays a rather limited role in REIT operations.

\subsection{Methodology}

\subsubsection{REIT Commercial Mortgages}

First, we use the asset level data directly, linking the presence of a label attesting to the energy efficiency or environmental performance of an individual building or a small portfolio of buildings to the mortgage collateralized by these assets. We estimate the following equation to assess the impact of the energy efficiency and environmental performance of the collateral on the mortgage spread:

$$
\begin{array}{r}
\text { Mortgage Spread }=f(\text { Environmental Certification,Building, Mortgage Characteristics, } \\
\text { Firm Characteristics })
\end{array}
$$

As building quality controls, we employ indicator variables for renovation, amenities and distance to public transport stops, as well as building size, a building vintage dummy (less than 10 years old), and the logarithm of the book value of the building. ${ }^{11}$ In all mortgage regressions, we control for year, state, and asset type-fixed effects.

We use the LTV ratio as one of the mortgage controls. Additionally, since lenders may keep

\footnotetext{
${ }^{11}$ In unreported regressions, we also directly use the age of the assets but find insignificant results due to nonlinearity in the relationship. Results are available upon request.
} 
the LTV lower for riskier firms or assets, we follow Titman et al. (2005) and employ an indicator variable for LTVs larger than 0.7 . This indicator variable should capture the higher LTV choice for less risky firms or assets. We also control for time to maturity (in years) and include variables for fixed-rate mortgages and cross-collateralization.

The quality of the borrowing firm is also likely to affect the mortgage spread. We therefore explicitly control for firm characteristics. Specifically, we include firm size, debt ratio, and the market-to-book ratio.

\subsubsection{REIT Corporate Bonds}

In order to estimate the impact of energy efficiency and environmental performance on the bond spread of a REIT we indirectly employ the asset level dataset, using the results of the matching to create a portfolio-level measure of environmental performance, following Eichholtz et al. (2012a). For each REIT, we calculate the dynamic portfolio share of environmentally certified assets, which is the ratio of the total square footage of certified buildings (measured by Energy Star, LEED, or both) and the total square footage of the portfolio of a REIT, thus indicating the degree to which a REIT portfolio includes environmentally efficient assets:

$$
\text { Environmental Certification Share }{ }_{i, t}^{g}=\frac{\sum_{l} \text { Sqft of Certified Buildings } s_{i, l, t}^{g}}{\sum_{l} \text { Sqft of Buildings } s_{i, l, t}}
$$

In this equation, $i$ stands for REIT $i, t$ stands for year $t, l$ stands for building $l$ and $g$ is the certification, which is either Energy Star, LEED, or both. In the multivariate analysis, we estimate the following equation, explaining bond spreads by energy efficiency and environmental certification characteristics, as well as bond characteristics and a set of control variables:

$$
\text { Bond Spread }=f(\text { Environmental Certification Share, Bond, Firm Characteristics })
$$

In Equation (5.3), we use the portfolio share of certified buildings in order to proxy for the environmental performance of each REIT. Bond characteristics include the logarithm of the value of the bond, year to maturity, bond rating and variables indicating whether the bond is callable or convertible. One can expect that the bond spread should increase by the total value of debt, as the bond becomes riskier if the total amount of debt increases. However, the amount of debt can also reflect the financial health of the issuer. For callable bonds, we expect a premium, reflecting the option value of the call and a discount for the convertible bonds. Higher bond ratings should also be associated with lower spreads.

Regarding the time to maturity, the literature suggests two possible outcomes (Goss and Roberts, 2011): according to the "trade-off" hypothesis, there is a positive relationship between spread and time to maturity, as a bond becomes riskier due to the longer lending period, in which unforeseen events can occur. Conversely, the "credit quality" hypothesis predicts a negative relationship between time to maturity and the spread, because longer-term borrowers are likely to be less risky borrowers.

We use lagged firm characteristics in our model. For these variables, we expect that firm size, measured by the logarithm of total assets, is associated with a lower spread, since larger 
firms are better able to withstand negative shocks to cash flows and may be less likely to default. As a further measure of financial risk, we exploit the debt ratio, measured as total debt divided by total assets. ${ }^{12}$ As the debt-to-asset ratio increases, firms should face higher bond spreads. We also control for firm $\mathrm{Q}$, measured by the ratio of the market value of assets to the book value of assets. A higher firm $\mathrm{Q}$ indicates better growth opportunities, implying that the bond spread should be lower.

In estimating the regression reported in Equation (5.3), we use bond data both at issuance and while trading in the secondary market. The bond data analysis at issuance is cross-sectional, while the secondary market data offer a panel setting. We acknowledge that endogeneity is a concern in non-experimental, cross-sectional studies. For example, environmentally certified buildings are not randomly assigned to portfolios and building owners do not randomly invest in the environmental performance of buildings. For the OLS estimates of Equation (5.3) to yield consistent estimates, we must therefore assume that our measure of environmental performance is uncorrelated with other explanatory variables.

We use two different robustness tests to overcome the endogeneity concerns. First, using the panel dataset, we apply a difference-in-difference approach, using the first difference of the bond spread and explanatory variables in order to eliminate the effects of unobservables. Our aim is to remove any possible impact of unobservable and time-invariant firm and bond characteristics, which can potentially be correlated with the share of environmentally certified buildings. By using differences, the impact of such time-invariant characteristics are removed, allowing us to observe directly the impact of a change in the share of certified buildings of a given REIT on the change in the bond spread.

Additionally, we use a two-stage least squares estimation. In the first stage, we regress the share of environmentally certified assets of each REIT portfolio on its lagged share and a local variable measuring the fraction of environmentally certified buildings in the area where a REIT's assets in the portfolio are located, combined with the other explanatory variables that we employ in the bond spread regressions. In order to create the weighted local measure of environmentally certified buildings, we use the market share of environmentally certified commercial buildings in each of the 30 largest markets in the U.S. over time. ${ }^{13}$ The weighted local measure of environmentally certified buildings is calculated by aggregating the sum of the "green" market shares multiplied by the ratio of the number of buildings in a REIT portfolio in that particular market. In the second stage, we regress the fitted measure of environmentally certified buildings on bond spreads and ratings. We perform the Hansen J (Hansen et al., 1996) and Kleibergen-Paap (Kleibergen and Paap, 2006) tests to check the validity and identification of the models.

\section{Environmental Certification Share $=f($ Local Greenness, Bond,}

$$
\text { Firm Characteristics) }
$$

$$
\text { Bond Spread }=g(\text { Environmental Certification Share, Bond, Firm Characteristics })
$$

\footnotetext{
${ }^{12}$ In unreported regressions, we also include the interest coverage, documenting similar results.

${ }^{13}$ See Holtermans et al. (2015) for a full list of the markets that are included.
} 
$\Delta$ Bond Spread $=f(\Delta$ Environmental Certification Share, $\Delta$ Bond Characteristics,

$\Delta$ Firm Characteristics)

\subsection{Empirical Findings}

\subsubsection{Commercial Mortgage Spreads and Environmental Certification}

Table 5.2 provides the results of Equation (5.1). We regress mortgage spreads on an indicator of energy efficiency and environmental certification, and a large set of control variables. The standard errors are heteroskedasticity-robust and clustered by REIT. In Columns 3 to 6 of the table, we present the results using the sample matched with CoStar data, more extensively controlling for building quality characteristics. The models explain 51 to 55 percent of the cross-sectional variation in mortgage spreads.

Coefficients for the control variables are in line with expectations and consistent across specifications. In four out of six specifications, the LTV coefficient is significantly positive; a higher level of borrowing at the individual building level increases the spread. The dummy indicating LTV ratios larger than 0.7 has a significantly negative coefficient, suggesting that less risky firms face lower spreads and that riskier firms are crowded out at higher LTV levels. Time-to-maturity has a negative impact on the spread, supporting the "credit quality" hypothesis. Fixed-rate mortgages have significantly higher spreads. Finally, when multiple assets collateralize the mortgage contract, the spread declines, although the coefficients are insignificant. This effect is most likely due to diversification.

The building quality controls obtained from CoStar, reported in Columns 3 to 6, have negative signs in all specifications. The results indicate that mortgages collateralized with buildings of higher quality have lower spreads. The presence of more than five amenities in a building, for example, is associated with a reduction in mortgage spread of 27 to 29 basis points. Building renovation decreases mortgage spreads by about 21 basis points. Proximity to public transport has the expected sign but is not statistically significant.

Importantly, we document that if a mortgage contract is collateralized by an environmentally certified asset, the borrower faces significantly lower spreads. Columns 1 and 3 show that the overall effect of environmental certification on mortgage spreads is statistically and economically significant, and is not materially affected by the inclusion of additional variables controlling for building quality. The decrease in mortgage spread is 35 to 36 basis points. For an average commercial mortgage in our sample, this translates into an annual interest payment that is lower by about USD 210,000 .

Columns 2 and 4 present the results of regressing mortgage spread on LEED and Energy Star indicators, and Columns 5 and 6 include only one of the indicators. The findings indicate that the documented effect is mostly determined by LEED certification. If the building collateralizing the mortgage is LEED certified, borrowers face 38 to 58 basis points lower mortgage spreads. On average, this implies lower annual mortgage interest payments of USD 230,000 to USD 323,000 for the mortgages in our sample. The results for Energy Star certification are reported 
in Columns 2, 4, and 6, and show certification coefficients that are negative, but statistically insignificant.

These findings suggest that mortgage lenders reflect the environmental characteristics of the certified buildings in mortgage pricing, leading to lower mortgage spreads for such buildings. Although we do not have information about the default rates of the underlying collateral, the findings are in line with the lower occupancy risk and higher income generated by environmentally certified buildings (Eichholtz et al., 2010, 2013; Fuerst and McAllister, 2011), as well as recent findings on lower default risk for environmentally certified assets in a broad pool of CMBS loans (An and Pivo, 2015).

Table 5.2: Environmental Certification and Mortgage Spreads (2006-2014)

\begin{tabular}{|c|c|c|c|c|c|c|}
\hline & $(1)$ & (2) & (3) & (4) & (5) & (6) \\
\hline Environmental certification & $-0.345^{* * *}$ & & $-0.363^{* * *}$ & & & \\
\hline (1=yes) & {$[0.110]$} & & {$[0.131]$} & & & \\
\hline LEED & & $-0.376^{* * *}$ & & $-0.436^{* * *}$ & $-0.584^{* * *}$ & \\
\hline (1=yes) & & {$[0.137]$} & & {$[0.158]$} & {$[0.158]$} & \\
\hline Energy Star & & -0.156 & & -0.043 & & -0.202 \\
\hline (1=yes) & & {$[0.156]$} & & {$[0.172]$} & & {$[0.205]$} \\
\hline Renovated & & & $-0.214^{* *}$ & $-0.217^{* *}$ & $-0.214^{* *}$ & $-0.213^{* *}$ \\
\hline (1=yes) & & & {$[0.088]$} & {$[0.088]$} & {$[0.089]$} & {$[0.091]$} \\
\hline On-site amenities & & & $-0.280^{* * *}$ & $-0.281^{* * *}$ & $-0.274^{* * *}$ & $-0.293^{* * *}$ \\
\hline (1=yes) & & & {$[0.103]$} & {$[0.103]$} & {$[0.104]$} & {$[0.107]$} \\
\hline Transit stop & & & -0.003 & 0.000 & -0.004 & -0.010 \\
\hline (1=yes) & & & {$[0.093]$} & {$[0.093]$} & {$[0.095]$} & {$[0.097]$} \\
\hline Log asset book value & $\begin{array}{c}-0.214^{* * *} \\
{[0.043]}\end{array}$ & $\begin{array}{c}-0.213^{* * *} \\
{[0.043]}\end{array}$ & $\begin{array}{c}-0.178^{* * *} \\
{[0.054]}\end{array}$ & $\begin{array}{c}-0.177^{* * *} \\
{[0.055]}\end{array}$ & $\begin{array}{c}-0.171^{* * *} \\
{[0.054]}\end{array}$ & $\begin{array}{c}-0.183^{* * *} \\
{[0.056]}\end{array}$ \\
\hline$\leq 10$ Years Old & $-0.148^{* *}$ & $-0.146^{* *}$ & $-0.165^{* *}$ & $-0.163^{* *}$ & $-0.179 * *$ & $-0.163^{*}$ \\
\hline (1=yes) & {$[0.072]$} & {$[0.072]$} & {$[0.082]$} & {$[0.081]$} & {$[0.081]$} & {$[0.084]$} \\
\hline LTV & 0.430 & 0.429 & $0.551^{*}$ & $0.553^{*}$ & $0.561^{*}$ & $0.545^{*}$ \\
\hline (fraction) & {$[0.284]$} & {$[0.285]$} & {$[0.309]$} & {$[0.309]$} & {$[0.310]$} & {$[0.315]$} \\
\hline LTV dummy & $-0.304^{* *}$ & $-0.305^{* *}$ & $-0.323^{* *}$ & $-0.324^{* *}$ & $-0.330^{* *}$ & $-0.317^{* *}$ \\
\hline$(\mathrm{LTV} \geq 0.7)$ & {$[0.141]$} & {$[0.141]$} & {$[0.153]$} & {$[0.153]$} & {$[0.153]$} & {$[0.155]$} \\
\hline Time-to-maturity & $-0.129^{* * *}$ & $-0.129 * * *$ & $-0.134^{* * *}$ & $-0.134^{* * *}$ & $-0.133^{* * *}$ & $-0.133^{* * *}$ \\
\hline (in years) & {$[0.012]$} & {$[0.012]$} & {$[0.014]$} & {$[0.014]$} & {$[0.014]$} & {$[0.014]$} \\
\hline Cross-collateralization & $-0.290^{*}$ & $-0.291^{*}$ & -0.225 & -0.224 & -0.230 & -0.241 \\
\hline (1=yes) & {$[0.160]$} & {$[0.160]$} & {$[0.163]$} & {$[0.163]$} & {$[0.162]$} & {$[0.164]$} \\
\hline Fixed rate & $1.630^{* * *}$ & $1.632^{* * *}$ & $1.745^{* * *}$ & $1.748^{* * *}$ & $1.740^{* * *}$ & $1.746^{* * *}$ \\
\hline (1=yes) & {$[0.162]$} & {$[0.162]$} & {$[0.179]$} & {$[0.179]$} & {$[0.178]$} & {$[0.180]$} \\
\hline Log firm size & -0.033 & -0.034 & -0.013 & -0.014 & -0.017 & -0.015 \\
\hline (lagged, $\mathrm{t}-1$ ) & {$[0.055]$} & {$[0.055]$} & {$[0.060]$} & {$[0.060]$} & {$[0.061]$} & {$[0.061]$} \\
\hline Market-to-book & -0.050 & -0.048 & 0.050 & 0.056 & 0.025 & 0.067 \\
\hline (lagged, t-1) & {$[0.180]$} & {$[0.180]$} & {$[0.206]$} & {$[0.206]$} & {$[0.209]$} & {$[0.215]$} \\
\hline Debt ratio & 0.338 & 0.340 & 0.501 & 0.502 & 0.503 & 0.497 \\
\hline (lagged, t-1) & {$[0.382]$} & {$[0.384]$} & {$[0.403]$} & {$[0.404]$} & {$[0.401]$} & {$[0.411]$} \\
\hline \multirow[t]{2}{*}{ Constant } & $3.108^{* * *}$ & $3.114^{* * *}$ & $2.110^{* *}$ & $2.097^{* *}$ & $2.125^{* *}$ & $2.181^{* *}$ \\
\hline & {$[0.819]$} & {$[0.820]$} & [0.859] & {$[0.860]$} & [0.879] & {$[0.884]$} \\
\hline
\end{tabular}


Table 5.2 (continued from previous page)

\begin{tabular}{lcccccc}
\hline Year fixed effects & yes & yes & yes & yes & yes & yes \\
State fixed effects & yes & yes & yes & yes & yes & yes \\
Asset type fixed effects & yes & yes & yes & yes & yes & yes \\
Observations & 4,553 & 4,553 & 2,707 & 2,707 & 2,660 & 2,645 \\
$\mathrm{R}^{2}$ & 0.51 & 0.51 & 0.55 & 0.55 & 0.55 & 0.55 \\
\hline
\end{tabular}

Notes: Table 5.2 presents the results of the linear regressions of mortgage spread on the LEED/Energy Star indicator, mortgage and building characteristics. The LEED (Energy Star) dummy indicates whether an asset collateralizing a mortgage is LEED (Energy Star) certified. Mortgage and building characteristics include the LTV ratio calculated as the ratio of encumbrance to the total book value of assets collateralizing a mortgage, the logarithm of asset book value, year to maturity and variables indicating whether the mortgage is a fixed-rate mortgage and whether there is any other asset collateralizing the mortgage. The regressions also include building quality characteristics in Columns 3 to 6 . All regressions include asset type dummies, year dummies and location dummies by state. Heteroskedasticity-robust and REIT-clustered standard errors are in brackets. ${ }^{*}, * *$, and ${ }^{* * *}$ indicate significance at the 10,5 , and 1 percent level, respectively.

To assess heterogeneity in the documented effects, we evaluate the impact of variation in certification levels on mortgage spreads. We use increasing levels of LEED certification, employing specifications that are otherwise similar to those employed previously. We first divide LEED certified buildings into two groups, by combining "Certified" and "Silver" certifications as the "low-level" dummy and "Gold" and "Platinum" certifications as the "high-level" dummy. We also separately evaluate "Gold" and "Platinum" labels. The hypothesis is that, as the level of LEED certification increases, we expect a larger reduction in mortgage spread. Results are reported in Table 5.3. The explanatory power of the models is comparable to previous specifications, and that also holds for the coefficients of the control variables.

In columns 1 and 2 of Table 5.3, we analyze mortgage spreads without the additional building quality characteristics from CoStar. We document a significantly negative relationship between LEED certification levels and mortgage spread. While mortgages on buildings with low-level certification have a spread that is 46 basis points lower, the high-level certifications reduce the mortgage spread by 59 basis points. The reduction is even larger for "Platinum" labels: we observe a 68 basis point decline in mortgage spreads for buildings with these labels. Based on the average mortgage size in the sample, if collateral would be LEED Platinum-certified, the interest expense on that mortgage would decline by approximately USD 410,000 per year.

Including the complete set of building quality controls, the certification coefficients increase relative to the findings in the first two columns, and continue to point to a decline in spreads as the level of buildings' environmental performance increases. The spread discount for high-level certifications remains statistically significant at 65 basis points when including the additional building characteristics. The discount for Platinum-certified collateral slightly declines to 61 basis points and is significant at the five-percent level. 
Table 5.3: LEED Certification Levels and Mortgage Spreads (2006-2014)

\begin{tabular}{|c|c|c|c|c|}
\hline & (1) & (2) & (3) & (4) \\
\hline Low-level LEED & $-0.460^{* *}$ & $-0.460^{* *}$ & $-0.539^{* * *}$ & $-0.539 * * *$ \\
\hline (1=yes) & {$[0.219]$} & {$[0.219]$} & {$[0.200]$} & {$[0.200]$} \\
\hline High-level LEED & $-0.585^{* * *}$ & & $-0.650^{* * *}$ & \\
\hline (1=yes) & [0.199] & & {$[0.242]$} & \\
\hline Gold & & $-0.572^{* *}$ & & $-0.658^{* *}$ \\
\hline (1=yes) & & {$[0.220]$} & & {$[0.283]$} \\
\hline Platinum & & $-0.681^{* * *}$ & & $-0.611^{* *}$ \\
\hline (1=yes) & & {$[0.242]$} & & {$[0.305]$} \\
\hline Renovated & & & $-0.213^{* *}$ & $-0.214^{* *}$ \\
\hline (1=yes) & & & [0.089] & {$[0.090]$} \\
\hline On-site amenities & & & $-0.275^{* * *}$ & $-0.275^{* * *}$ \\
\hline (1=yes) & & & {$[0.104]$} & {$[0.104]$} \\
\hline Transit stop & & & -0.004 & -0.004 \\
\hline (1=yes) & & & {$[0.095]$} & [0.095] \\
\hline Log asset book value & $-0.208^{* * *}$ & $-0.208^{* * *}$ & $-0.171^{* * *}$ & $-0.170^{* * *}$ \\
\hline & {$[0.043]$} & [0.043] & {$[0.054]$} & {$[0.054]$} \\
\hline$\leq 10$ Years Old & $-0.154^{* *}$ & $-0.154^{* *}$ & $-0.179^{* *}$ & $-0.179^{* *}$ \\
\hline (1=yes) & {$[0.071]$} & {$[0.071]$} & {$[0.081]$} & {$[0.081]$} \\
\hline LTV & 0.451 & 0.452 & $0.563^{*}$ & $0.563^{*}$ \\
\hline (fraction) & {$[0.285]$} & {$[0.285]$} & {$[0.311]$} & {$[0.311]$} \\
\hline LTV dummy & $-0.312^{* *}$ & $-0.312^{* *}$ & $-0.332^{* *}$ & $-0.332^{* *}$ \\
\hline$(\mathrm{LTV} \geq 0.7)$ & {$[0.142]$} & {$[0.142]$} & {$[0.154]$} & {$[0.154]$} \\
\hline Time-to-maturity & $-0.128^{* * *}$ & $-0.128^{* * *}$ & $-0.133^{* * *}$ & $-0.133^{* * *}$ \\
\hline (in years) & {$[0.012]$} & {$[0.012]$} & {$[0.014]$} & {$[0.014]$} \\
\hline Cross-collateralization & $-0.289^{*}$ & $-0.289^{*}$ & -0.231 & -0.231 \\
\hline (1=yes) & {$[0.158]$} & {$[0.158]$} & {$[0.162]$} & {$[0.162]$} \\
\hline Fixed rate & $1.629^{* * *}$ & $1.629^{* * *}$ & $1.739^{* * *}$ & $1.739^{* * *}$ \\
\hline (1=yes) & {$[0.160]$} & {$[0.160]$} & {$[0.178]$} & {$[0.179]$} \\
\hline Log firm size & -0.035 & -0.035 & -0.017 & -0.017 \\
\hline (lagged, t-1) & {$[0.056]$} & {$[0.056]$} & {$[0.061]$} & {$[0.061]$} \\
\hline Market-to-book & -0.070 & -0.070 & 0.025 & 0.025 \\
\hline (lagged, t-1) & {$[0.182]$} & {$[0.182]$} & {$[0.209]$} & [0.209] \\
\hline Debt ratio & 0.337 & 0.337 & 0.503 & 0.503 \\
\hline (lagged, t-1) & {$[0.381]$} & {$[0.381]$} & {$[0.401]$} & {$[0.401]$} \\
\hline \multirow[t]{2}{*}{ Constant } & $3.090 * * *$ & $3.091^{* * *}$ & $2.130^{* *}$ & $2.129 * *$ \\
\hline & {$[0.832]$} & {$[0.832]$} & {$[0.881]$} & {$[0.880]$} \\
\hline
\end{tabular}


Table 5.3 (continued from previous page)

\begin{tabular}{lcccc}
\hline & $(1)$ & $(2)$ & $(3)$ & $(4)$ \\
\hline Year fixed effects & yes & yes & yes & yes \\
State fixed effects & yes & yes & yes & yes \\
Asset type fixed effects & yes & yes & yes & yes \\
Observations & 4,450 & 4,450 & 2,660 & 2,660 \\
$\mathrm{R}^{2}$ & 0.52 & 0.52 & 0.55 & 0.55 \\
\hline
\end{tabular}

Notes: Table 5.3 shows the relationship between LEED certification levels and mortgage spread. The low-level LEED dummy includes Certified and Silver LEED labels. The high-level LEED dummy includes Gold and Platinum LEED labels. Gold and Platinum dummies indicate Gold and Platinum LEED labels, respectively. All regressions include asset type dummies, year dummies and location dummies by state. Heteroskedasticity-robust and REIT-clustered standard errors are in brackets. ${ }^{*}, * *$, and ${ }^{* * *}$ indicate significance at the 10,5 , and 1 percent level, respectively.

\subsubsection{Corporate Bond Spreads and Environmental Certification}

We analyze REIT corporate bond spreads by investigating the relationship between the share of environmentally certified space in REIT portfolios and bond spreads at the time of origination. In the REIT corporate bond sample, we observe 234 bond originations from 2006 to 2014. Table 5.4 presents the results of Equation (5.3). Columns 1 to 3 show the OLS regressions, while Columns 4 to 6 show the 2-stage GMM regressions, using the "regional green share" as the instrument. The results of the two different analyses are consistent with respect to the observed outcomes: the size of the coefficients, statistical significance levels and explanatory power of the models are only marginally affected.

Table 5.4: Environmental Certification and Corporate Bond Spreads at Origination (2006-2014)

\begin{tabular}{|c|c|c|c|c|c|c|}
\hline & (1) & (2) & (3) & (4) & (5) & (6) \\
\hline & \multicolumn{3}{|c|}{ OLS } & \multicolumn{3}{|c|}{ 2-Stage GMM } \\
\hline Green share & $-1.599^{*}$ & & & $-2.017^{* *}$ & & \\
\hline (in percent) & {$[0.892]$} & & & {$[0.989]$} & & \\
\hline LEED share & & $-2.150^{* *}$ & & & $-2.398^{* *}$ & \\
\hline (in percent) & & [0.973] & & & [1.097] & \\
\hline $\begin{array}{l}\text { Energy Star share } \\
\text { (in percent) }\end{array}$ & & & $\begin{array}{r}-1.542 \\
{[1.358]}\end{array}$ & & & $\begin{array}{c}-1.792 \\
{[1.523]}\end{array}$ \\
\hline Log firm size & -0.066 & -0.062 & -0.071 & -0.051 & -0.062 & -0.081 \\
\hline (lagged, t-1) & {$[0.134]$} & {$[0.134]$} & {$[0.136]$} & {$[0.165]$} & {$[0.163]$} & {$[0.171]$} \\
\hline Market-to-book & -0.346 & -0.350 & -0.324 & -0.158 & -0.184 & -0.197 \\
\hline (lagged, t-1) & {$[0.233]$} & {$[0.232]$} & {$[0.233]$} & {$[0.287]$} & {$[0.280]$} & {$[0.299]$} \\
\hline Debt ratio & 0.615 & 0.621 & 0.559 & 0.262 & 0.208 & 0.513 \\
\hline (lagged, t-1) & {$[0.481]$} & {$[0.477]$} & {$[0.488]$} & {$[0.730]$} & {$[0.738]$} & {$[0.711]$} \\
\hline Moody's rating & $-0.292^{* * *}$ & $-0.297^{* * *}$ & $-0.282^{* * *}$ & $-0.416^{* * *}$ & $-0.410^{* * *}$ & $-0.357^{* *}$ \\
\hline (8 to 17$)$ & {$[0.072]$} & {$[0.072]$} & {$[0.074]$} & {$[0.145]$} & {$[0.143]$} & {$[0.139]$} \\
\hline Log bond value issued & -0.129 & -0.124 & -0.128 & -0.057 & -0.045 & -0.079 \\
\hline (in million dollars) & {$[0.156]$} & {$[0.155]$} & [0.155] & {$[0.121]$} & {$[0.121]$} & {$[0.122]$} \\
\hline
\end{tabular}


Table 5.4 (continued from previous page)

\begin{tabular}{lcccccc}
\hline Time-to-maturity & -0.019 & -0.019 & -0.018 & -0.006 & -0.005 & -0.010 \\
(in years) & {$[0.027]$} & {$[0.027]$} & {$[0.027]$} & {$[0.020]$} & {$[0.020]$} & {$[0.021]$} \\
Callable & 0.120 & 0.122 & 0.106 & 0.128 & 0.128 & 0.090 \\
$(1=$ yes) & {$[0.149]$} & {$[0.148]$} & {$[0.149]$} & {$[0.130]$} & {$[0.129]$} & {$[0.129]$} \\
Convertible & $-2.207^{* * *}$ & $-2.196^{* * *}$ & $-2.210^{* * *}$ & $-3.018^{* * *}$ & $-3.030^{* * *}$ & $-2.939^{* * *}$ \\
(1=yes) & {$[0.567]$} & {$[0.568]$} & {$[0.566]$} & {$[0.708]$} & {$[0.705]$} & {$[0.710]$} \\
Constant & $7.380^{* * *}$ & $7.350^{* * *}$ & $7.300^{* * *}$ & $8.837^{* * *}$ & $8.878^{* * *}$ & $8.555^{* * *}$ \\
& {$[1.818]$} & {$[1.810]$} & {$[1.830]$} & {$[1.526]$} & {$[1.526]$} & {$[1.578]$} \\
& & & & & & \\
Year fixed effects & yes & yes & yes & yes & yes & yes \\
Asset type fixed effects & yes & yes & yes & yes & yes & yes \\
Observations & 234 & 234 & 234 & 182 & 182 & 182 \\
$R^{2}$ & 0.77 & 0.77 & 0.77 & 0.76 & 0.76 & 0.76 \\
Hansen J (prob.) & - & - & - & 0.986 & 0.768 & 0.289 \\
Kleibergen-Paap (prob.) & - & - & - & 0.000 & 0.000 & 0.008 \\
\hline
\end{tabular}

Notes: Table 5.4 represents the OLS and 2-stage GMM regressions of bond spread on LEED/Energy Star share, bond characteristics and firm characteristics at bond origination. LEED (Energy Star) share is the ratio of total square feet of LEED (Energy Star) certified buildings to the total square feet of the portfolio in year $t$. Bond characteristics include the logarithm of debt value, year to maturity, Moody's rating and dummies indicating whether the bond is callable and convertible. Firm characteristics cover the logarithm of total assets, debt-to-asset ratio and firm $\mathrm{Q}$ calculated as the ratio of market value of assets to book value of assets. All financial controls are observed at year $\mathrm{t}-1$. The regressions include asset type and year dummies. In the first stage of the last three regressions, we regress LEED (Energy Star) share on the lagged LEED (Energy Star) share, a local greenness measure and the explanatory variables from the second stage regressions. Hansen J and Kleibergen-Paap test probabilities for over-identification and under-identification are reported in the table. Heteroskedasticity-robust and firm-clustered standard errors are in brackets. ${ }^{*}, * *$, and ${ }^{* * *}$ indicate significance at the 10, 5, and 1 percent level, respectively.

We document that the overall portfolio share of environmentally certified buildings and the LEED share significantly lower the bond spread. A one-standard deviation increase in overall "green" share and LEED share decreases the bond spread by 8 and 9 basis points, respectively. On average, this corresponds to a decline in annual interest expense of USD 76,000 and USD 88,000 , respectively. The results for the 2-stage GMM regressions, where we explicitly control for potential endogeneity, show a slightly higher impact of portfolio greenness on bond spreads, corresponding to an 11 basis point decrease in bond spreads for a one-standard deviation increase in both the overall share of environmentally certified buildings in a REIT portfolio and the share of LEED certified buildings. ${ }^{14}$ Even though the measure of environmental concerns is quite different, the discounts we document on the bond spreads are remarkably similar in magnitude as compared to Goss and Roberts (2011) and Chava (2014).

It should be noted that the average LEED share is 1.13 percent of the portfolio, with a standard deviation of 3.55. In order to achieve the spread reduction reported above, an average REIT

\footnotetext{
${ }^{14}$ In the two-stage least squares regressions, we reject the null hypothesis of the Kleibergen-Paap test that the model is under-identified and do not reject the null hypothesis of the Hansen J Test that the instruments are valid at the one percent significance level, indicating that our instruments are valid and are performing in line with expectations.
} 
will thus have to quadruple its portfolio share of green buildings. Hence, although we find a statistically significant impact of portfolio greenness on bond spreads, the economic significance is relatively small. Given the still-modest share of environmentally certified buildings on the balance sheets of REITs, this finding is in line with expectations.

The control variables show that the corporate bond rating and the convertibility option are the most important determinants of REIT bond spreads at origination, irrespective of the regression specification. For example, a one-notch increase in credit rating decreases the bond spread with 29 to 42 basis points.

Subsequently, we examine the development of REIT bond spreads in the secondary market. In Table 5.5, we present the results from the OLS and 2-stage GMM regressions of bond spreads measured over time, using a panel dataset on firm characteristics, bond characteristics, and the extent to which a REIT portfolio includes LEED and Energy Star certified buildings. The standard errors are again heteroskedasticity robust and clustered by firm.

The signs of the coefficients on the control variables of the bond and firm controls are as expected. Time to maturity has a negative impact on bond spreads, supporting the "credit quality" hypothesis proposed by Goss and Roberts (2011). If the bond is callable, the spread increases significantly, reflecting the option value of the call. For convertible bonds, the spread is significantly lower. The coefficient of the rating is insignificant, although the sign of the coefficient is as expected. The coefficient of the market-to-book ratio is significantly negative. This indicates that higher future growth opportunities lower the bond spread. An 0.1 increase in the market-to-book ratio results in a 13 to 14 basis-point increase in the bond spread.

Table 5.5: Environmental Certification and Corporate Bond Spreads on Secondary Market (2006-2014)

\begin{tabular}{|c|c|c|c|c|c|c|}
\hline & (1) & (2) & (3) & (4) & (5) & (6) \\
\hline & \multicolumn{3}{|c|}{ Panel Data - OLS } & \multicolumn{3}{|c|}{ 2-Stage GMM } \\
\hline Green share & $-2.558^{* * *}$ & & & $-4.249^{* * *}$ & & \\
\hline (in percent) & {$[0.949]$} & & & {$[1.071]$} & & \\
\hline LEED share & & $-3.143^{* * *}$ & & & $-5.089 * * *$ & \\
\hline (in percent) & & {$[1.001]$} & & & {$[1.190]$} & \\
\hline Energy Star share & & & -2.057 & & & $-3.433^{* *}$ \\
\hline (in percent) & & & {$[1.323]$} & & & {$[1.658]$} \\
\hline Log firm size & -0.156 & -0.152 & -0.166 & $0.391^{*}$ & 0.247 & $0.629^{* *}$ \\
\hline (lagged, $\mathrm{t}-1$ ) & {$[0.191]$} & {$[0.194]$} & {$[0.196]$} & {$[0.218]$} & {$[0.191]$} & {$[0.275]$} \\
\hline Market-to-book & $-1.356^{* * *}$ & $-1.331^{* * *}$ & $-1.346^{* * *}$ & -0.215 & -0.389 & -0.024 \\
\hline (lagged, t-1) & {$[0.440]$} & {$[0.436]$} & {$[0.442]$} & {$[0.322]$} & {$[0.291]$} & {$[0.375]$} \\
\hline Debt ratio & $1.726^{*}$ & $1.670^{*}$ & $1.663^{*}$ & $-2.404^{* * *}$ & $-2.122^{* * *}$ & $-2.930^{* * *}$ \\
\hline (lagged, $t-1$ ) & [0.952] & [0.941] & {$[0.963]$} & {$[0.783]$} & {$[0.763]$} & {$[0.824]$} \\
\hline Moody's rating & -0.116 & -0.118 & -0.100 & $-0.737^{* * *}$ & $-0.617^{* * *}$ & $-0.727^{* * *}$ \\
\hline (8 to 17$)$ & {$[0.120]$} & {$[0.122]$} & {$[0.121]$} & {$[0.176]$} & {$[0.153]$} & {$[0.196]$} \\
\hline Log bond value issued & $-0.540^{* *}$ & $-0.529 * *$ & $-0.529 * *$ & $-0.319 *$ & -0.291 & $-0.343^{*}$ \\
\hline (in million dollars) & {$[0.238]$} & {$[0.234]$} & {$[0.224]$} & [0.193] & {$[0.190]$} & {$[0.197]$} \\
\hline Time-to-maturity & $-0.070^{*}$ & $-0.070^{*}$ & $-0.071^{*}$ & $-0.064^{* *}$ & -0.037 & $-0.098^{* * *}$ \\
\hline (in years) & {$[0.037]$} & {$[0.037]$} & {$[0.037]$} & {$[0.029]$} & {$[0.026]$} & {$[0.036]$} \\
\hline Callable & $0.714^{* * *}$ & $0.716^{* * *}$ & $0.695^{* * *}$ & $0.440^{* * *}$ & $0.411^{* * *}$ & $0.444^{* * *}$ \\
\hline (1=yes) & {$[0.183]$} & {$[0.182]$} & {$[0.179]$} & {$[0.099]$} & {$[0.097]$} & [0.103] \\
\hline
\end{tabular}


Table 5.5 (continued from previous page)

\begin{tabular}{|c|c|c|c|c|c|c|}
\hline & (1) & (2) & (3) & (4) & (5) & (6) \\
\hline & \multicolumn{3}{|c|}{ Panel Data - OLS } & \multicolumn{3}{|c|}{ 2-Stage GMM } \\
\hline Convertible & $-3.649^{* * *}$ & $-3.648^{* * *}$ & $-3.622^{* * *}$ & $-3.361^{* * *}$ & $-3.601^{* * *}$ & $-2.955^{* * *}$ \\
\hline (1=yes) & {$[0.529]$} & {$[0.531]$} & {$[0.538]$} & {$[0.984]$} & {$[0.981]$} & [1.011] \\
\hline \multirow[t]{2}{*}{ Constant } & $10.372^{* * *}$ & $10.242^{* * *}$ & $10.232^{* * *}$ & $9.957^{* * *}$ & $10.180^{* * *}$ & $6.292^{* *}$ \\
\hline & [2.921] & [2.910] & {$[2.883]$} & {$[2.290]$} & {$[2.187]$} & [2.489] \\
\hline Year fixed effects & yes & yes & yes & yes & yes & yes \\
\hline Asset type fixed effects & yes & yes & yes & yes & yes & yes \\
\hline Observations & 1,690 & 1,690 & 1,690 & 707 & 705 & 707 \\
\hline $\mathrm{R}^{2}$ & 0.74 & 0.74 & 0.74 & 0.81 & 0.81 & 0.80 \\
\hline Hansen J (prob.) & - & - & - & 0.550 & 0.865 & 0.0276 \\
\hline Kleibergen-Paap (prob.) & - & - & - & 0.000 & 0.000 & 0.000 \\
\hline
\end{tabular}

Notes: Table 5.5 presents the OLS and 2-stage GMM regressions of bond spread on LEED/Energy Star share, bond characteristics and firm characteristics for the secondary market sample. LEED (Energy Star) share is the ratio of total square feet of LEED (Energy Star) certified buildings to the total square feet of the portfolio in year $t$. Bond characteristics include the logarithm of debt value, year to maturity, Moody's rating and dummies indicating whether the bond is callable and convertible. Firm characteristics include the logarithm of total assets, debt-to-asset ratio and firm $\mathrm{Q}$ calculated as the ratio of market value of assets to book value of assets. All financial controls are observed at year $t-1$. The regressions include asset type dummies and year dummies. In the first stage of the last three regressions, we regress the LEED (Energy Star) share on the lagged LEED (Energy Star) share, local greenness measure and the explanatory variables from the second stage regressions. Hansen J and Kleibergen-Paap test probabilities for over-identification and under-identification are reported in the table. Heteroskedasticity-robust and firm-clustered standard errors are in brackets. ${ }^{*}, * *$, and ${ }^{* * *}$ indicate significance at the 10,5 , and 1 percent level, respectively.

In Column 1 of Table 5.5, we evaluate the spread impact associated with the temporal dynamics in the share of LEED or Energy Star certified assets in REIT portfolios. We document that a one-standard deviation increase in the share of environmentally certified buildings decreases the spread by 12 basis points, slightly higher as compared to the results of the crosssectional regressions reported in Table 5.4. This corresponds to a reduction of USD 118,000 in interest payment for the average REIT corporate bond in the sample.

In Columns 2 and 3, we investigate separately the impact of LEED and Energy Star shares. A one-standard deviation increase in the LEED share reduces the bond spread by 11 basis points. While the coefficient of the Energy Star share has the expected sign, the effect is statistically insignificant as indicated in Column 3. Columns 4 to 6 of Table 5.5 show the two-stage least square estimation results. We find similar results, but with a somewhat higher significance and a higher impact of the portfolio share of environmental certification of buildings on bond spreads, irrespective of how we define "greenness."

A one-standard deviation increase in the share of environmentally certified buildings decreases the bond spread by 24 basis points. A one-standard deviation increase in LEED share reduces the bond spread by 22 basis points, corresponding to an average decline in the interest expense of USD 223,000. Similarly, a one-standard deviation increase in the Energy Star portfolio share decreases the spread by 14 basis points. 


\subsubsection{Robustness Checks}

In order to further establish causality between the share of environmentally certified buildings in a REIT portfolio and corporate bond spreads, we analyze the effect of greenness on bond spreads using a robustness check that exploits a difference-in-difference approach. We use the first difference by year in the bond spread and control variables to remove the impact of time-invariant observable and unobservable characteristics.

The results of this robustness check are presented in Table 5.6. Most importantly, in all specifications, the coefficients on the environmental performance measures have negative signs, and the effects are larger as compared to previous specifications. For example, a one-percent increase in the overall share of environmentally certified buildings in a portfolio significantly lowers the spread of a REIT corporate bond by 17 basis points. While the coefficient of change in LEED share is insignificant, the coefficient of change in the Energy Star share is now significantly negative. A one-percent change in the Energy Star share leads to a 17 basis point decline in the bond spread in the secondary market.

Table 5.6: Environmental Certification and Corporate Bond Spreads (2007-2014) $\Delta$ Bond Spread $\Delta$ Bond Spread $\Delta$ Bond Spread

(1)

$-16.737^{* * *}$

$[5.795]$

$\triangle$ LEED share

$\Delta$ Energy Star share

\begin{tabular}{lccc}
\hline$\Delta$ Green share & $-16.737^{* * *}$ & & \\
& {$[5.795]$} & & \\
$\Delta$ LEED share & & -11.378 & \\
& & {$[9.359]$} & $-17.194^{* * *}$ \\
$\Delta$ Energy Star share & & {$[6.194]$} \\
& & & $6.176^{* * *}$ \\
$\Delta$ Log firm size & $6.258^{* * *}$ & $6.123^{* * *}$ & {$[1.614]$} \\
(lagged, t-1) & {$[1.629]$} & {$[1.633]$} & 0.971 \\
$\Delta$ Market-to-book & 1.003 & 0.925 & {$[1.572]$} \\
(lagged, t-1) & {$[1.572]$} & {$[1.573]$} & $11.270^{* *}$ \\
$\Delta$ Debt ratio & $11.027^{* *}$ & $11.085^{* *}$ & {$[5.266]$} \\
(lagged, t-1) & {$[5.289]$} & {$[5.277]$} & -1.365 \\
$\Delta$ Moody's rating & -1.411 & -1.332 & {$[1.471]$} \\
(8 to 17) & {$[1.473]$} & {$[1.467]$} & 1,344 \\
Observations & 1,344 & 1,344 & 0.05 \\
R $^{2}$ & 0.05 & 0.05 & \\
\hline
\end{tabular}

(2)

Notes: Table 5.6 presents the difference-in-difference regression of bond spread on LEED/Energy Star share, bond characteristics and firm characteristics. LEED (Energy Star) share is the ratio of total square feet of LEED (Energy Star) certified assets to the total square feet of the portfolio in year $t$. Firm characteristics cover the logarithm of total assets, debt-to-asset ratio and firm $\mathrm{Q}$ calculated as the ratio of market value of assets to book value of assets. All of the financial controls are observed at year $\mathrm{t}-1$ and first-differenced. Among bond characteristics, we also use the first difference of a bond's rating. Heteroskedasticity-robust and firm-clustered standard errors are in brackets. ${ }^{*}, * *$, and ${ }^{* *}$ indicate significance at the 10,5 , and 1 percent level, respectively. 
Irrespective of the specification (OLS, 2SLS, difference-in-difference), we document that the extent of environmental certification in the portfolios of REITs is significantly associated with the spreads on corporate bonds, even though the effect is economically quite small. Our results also provide evidence that environmental certification (or the effects thereof) are recognized somewhat more strongly in the secondary markets as compared to the pricing effects at the time of origination.

It has been argued that environmental performance does not just affect the cost of a firm's debt, but also its debt capacity (Sharfman and Fernando, 2008). This may give rise to a potential endogeneity issue, since the higher debt capacity may also affect spreads. As a robustness analysis, we therefore investigate whether an increasing share of environmentally certified buildings in the portfolio of a REIT is associated with a higher debt capacity. By examining the LTV ratios of mortgages collateralized by environmentally certified and non-certified buildings, and the debt ratios of REITs with high and low portfolio shares of environmentally certified buildings, we are able to investigate this hypothesis in more detail.

Table 5.7: Debt Capacity Analysis

\begin{tabular}{|c|c|c|c|c|}
\hline \multicolumn{5}{|c|}{ Panel A-Commercial Mortgages } \\
\hline & \multicolumn{4}{|c|}{ Loan-to-Value } \\
\hline & Certified & None & Certified-None ( $t$-stat) & \\
\hline Env. certified & $0.51(\mathrm{~N}=177)$ & $0.55(\mathrm{~N}=4,376)$ & $-0.04(2.03)^{* *}$ & \\
\hline LEED & $0.49(\mathrm{~N}=96)$ & $0.55(\mathrm{~N}=4,457)$ & $-0.06(2.10)^{* *}$ & \\
\hline Energy Star & $0.52(\mathrm{~N}=103)$ & $0.55(\mathrm{~N}=4,450)$ & $-0.03(1.18)$ & \\
\hline \multicolumn{5}{|c|}{ Panel B - Corporate Bonds at Issuance } \\
\hline & \multicolumn{4}{|c|}{ Debt Ratio } \\
\hline & High Portfolio Share & Low Portfolio Share & None & High-None (t-stat) \\
\hline Env. certified & $0.51(\mathrm{~N}=70)$ & $0.51(\mathrm{~N}=75)$ & $0.52(\mathrm{~N}=89)$ & $-0.00(0.23)$ \\
\hline LEED & $0.50(\mathrm{~N}=62)$ & $0.53(\mathrm{~N}=63)$ & $0.51(\mathrm{~N}=109)$ & $-0.01(0.74)$ \\
\hline \multirow[t]{3}{*}{ Energy Star } & $0.51(\mathrm{~N}=52)$ & $0.54(\mathrm{~N}=61)$ & $0.50(\mathrm{~N}=121)$ & $0.01(0.96)$ \\
\hline & \multicolumn{4}{|c|}{ Bond Value (million dollars) } \\
\hline & High Portfolio Share & Low Portfolio Share & None & High-None ( $t$-stat) \\
\hline Env. certified & $98.64(\mathrm{~N}=70)$ & $98.69(\mathrm{~N}=75)$ & $100.00(\mathrm{~N}=89)$ & $-1.36(0.55)$ \\
\hline LEED & $100.40(\mathrm{~N}=62)$ & $100.00(\mathrm{~N}=63)$ & $98.20(\mathrm{~N}=109)$ & $1.83(0.71)$ \\
\hline Energy Star & $96.25(\mathrm{~N}=52)$ & $100.03(\mathrm{~N}=61)$ & $100.00(\mathrm{~N}=121)$ & $-3.75(1.43)$ \\
\hline
\end{tabular}

Notes: Table 5.7 presents univariate analysis on debt capacity. Specifically, the mean-diiference tests are performed to compare environmental certification sample with the rest of the sample. For the commercial mortgage sample, mean difference test is performed for the LTV ratio calculated as the ratio of encumbrance to the total book value of assets collateralizing a mortgage. Mean difference tests are also shown for the debt-to-asset ratio and the bond value for the corporate bond analysis at issuance.

Panel A of Table 5.7 presents the results of a simple non-parametric comparison and a meandifference test for the sample of mortgages. We compare the LTV for mortgages collateralized by environmentally certified and non-certified buildings. The simple t-tests do not show significantly higher LTVs for mortgages with environmentally certified collateral. In fact, we actually observe somewhat lower LTVs for mortgages with environmentally certified collateral.

In Panel B, we compare the overall debt-to-asset ratios and outstanding bond values for the sample of REIT corporate bonds. We group REITs into three categories based on their 
overall share of environmentally certified buildings. First, we analyze the REITs that do not invest in environmentally certified buildings at all. For the remainder of the sample, we classify the REITs that have a share of environmentally certified buildings in their portfolio below the median as the "low portfolio share" group and REITs with a share above the median as the "high-portfolio share" group. We then calculate the average debt-to-asset ratio and corporate bond value for each group and perform a mean-difference test between the non-certified share and high-certified share groups.

The results of these simple non-parametric comparisons show no observable, significant differences in the average debt-to-asset ratio between these groups. Bond values are lower when using Energy Star as the environmental certification, and higher — albeit insignificantly — for LEED. Summarizing, we conclude that the debt capacity is not significantly different for REITs with a higher fraction of environmentally certified buildings.

\subsection{Conclusion and Discussion}

The environmental performance of private firms can significantly affect the environment, and the extent to which firms incorporate corporate social responsibility (CSR) in their business strategy and operations may thus have implications for society. There is an ongoing debate about the financial outcomes of CSR considerations, mostly focusing on operating measures of profitability. But beyond affecting operational performance, the CSR credentials of a firm may also influence its ability to raise capital, and the price of that capital (Chava, 2014).

This chapter is among the first studies to investigate the impact of direct measures of corporate social responsibility - energy efficiency and environmental performance - on firms' cost of capital. In addition to analyzing cost of capital at the corporate level, we also address the financing cost of individual assets owned by firms. We focus on the real estate sector, which allows us to take this unique two-pronged perspective, given the explicit link between real assets and the mortgages that collateralize such assets.

This dual approach also enables addressing some of the concerns about endogeneity that are common in the literature regarding the financial effects of corporate social responsibility. At the asset level, we control for a large number of observable characteristics that may be correlated with environmental performance. At the corporate level, we apply a two-stage GMM method, instrumenting our unique measure of CSR performance by an exogenous indicator. In addition, we exploit the time-variation in both corporate bond pricing and CSR performance, using secondary market data and our real estate-specific measure of corporate environmental performance.

Evaluating the mortgage spreads of environmentally certified buildings owned by REITs, we document that commercial mortgages on assets certified by Energy Star and LEED have significantly lower spreads as compared to non-certified assets. This effect is economically significant; if the collateral is environmentally certified, the mortgage spread declines by 35 to 36 basis points. At the point of means, the interest expense for a mortgage in our sample decreases with some USD 200,000.

We also evaluate different levels of environmental certification. While both the coefficients on "low-level" and "high-level" LEED certifications are significant, we observe larger spread 
discounts as the certification levels increase. The difference in spread is 61 to 68 basis points for the highest performing, Platinum-labeled LEED buildings, translating into a reduction in the annual interest payments for the average mortgage in our sample of USD 410,000.

Analyzing corporate bond spreads, we document that firms with a more environmentally efficient portfolio, measured by both Energy Star and LEED certification, have significantly lower bond spreads. Regarding the impact of certification on the cost of debt at bond issuance, we find that a one-standard deviation increase in the LEED portfolio share decreases the spread by about 11 to 22 basis points, which translates into a USD 111,000 to USD 223,000 reduction in the interest payment for an average REIT bond. In the secondary market, if the share of environmentally certified buildings increases by one-standard deviation, the bond spread declines by 24 basis points. A simple robustness test shows that the results are not influenced by debt capacity differences between REITs that exhibit different levels of environmental performance, or by the use of a difference-in-difference analysis. These findings provide an indication that portfolio "greenness" reduces the cost of debt for REITs, possibly reflecting the lower risk and higher income associated with environmentally certified buildings. Although the effects are statistically significant, the economic significance at the portfolio level is quite small, which is in line with findings for general corporates (Goss and Roberts, 2011) and in line with our expectations, given the limited share of environmentally certified buildings in the portfolio of the average of U.S. REIT.

The findings in this chapter have some implications for REITs, investors, and policy makers. The commercial real estate sector is responsible for 46 percent of total U.S. energy consumption and emits 981 million metric tons of carbon dioxide per annum. This environmental externality is currently addressed through regulatory responses that mostly focus on increasing market efficiency through enhanced transparency. More than ten major U.S. cities, including Boston, New York, Washington D.C., as well as the state of California, have enacted regulation mandating the disclosure of commercial building energy performance. In addition, voluntary "green" certification schemes have diffused rapidly in the marketplace. If the capital market is efficient in pricing environmental performance, it will also be able to price environmental underperformance. This may have implications for the cost of capital of inefficient assets, and for their market values, providing an incentive for investors and REITs to develop investment strategies addressing the energy efficiency and environmental performance of buildings. This effect would provide a partial, market-based solution to an otherwise daunting policy challenge, perhaps slowly reducing the negative environmental impact of the capital building stock. 


\section{Appendix}

\section{A The REIT Bond Market}

Figure A.1: Number of REIT Bonds at Origination and in the Secondary Market

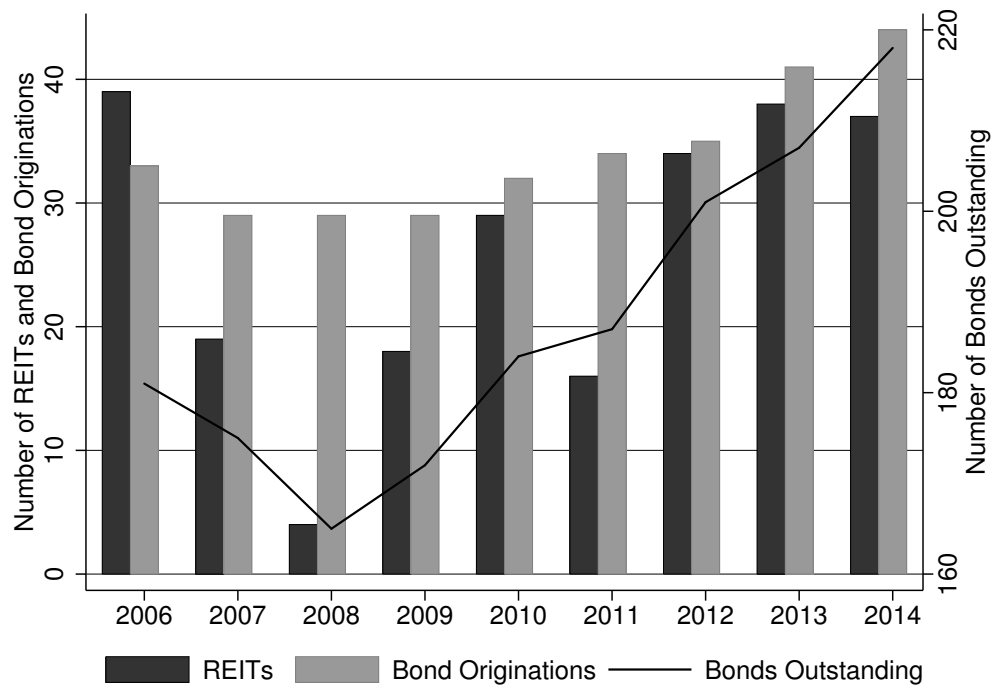

Notes: The figure shows the number of REITs and the number of corporate bond originations by REITs in the sample by year. The black line represents the number of outstanding REIT corporate bonds in the secondary market over time. 


\section{Chapter 6}

\section{Energy Efficiency and Economic Value in Affordable Housing*}

\subsection{Introduction}

Approximately 27 percent of aggregate energy use in the European Union's member states stems from the residential sector (Bertoldi et al., 2012). In 2010, this resulted in an estimated 225 billion euro energy bill and 630 million tons of $\mathrm{CO}_{2}$ emissions for the European housing sector. ${ }^{2}$

This illustrates the economic importance of energy consumption in housing, and the European Union continues to encourage the uptake of energy efficiency measures in the built environment. The Energy Performance of Buildings Directive of 2003, its recast in 2010, the Energy Efficiency Plan of 2011 and the subsequent 80 billion euro Horizon 2020 energy efficiency stimulus package all aim to stimulate the improvement of energy efficiency and a reduction in energy demand from buildings through regulatory directives, energy efficiency measurement initiatives and financial incentives. On top of that, many member states have their own rules and incentives stimulating sustainability in the built environment.

This chapter looks at the financial outcomes of energy efficiency in an important and hitherto neglected segment of the housing market in the energy policy literature: the affordable housing sector. Affordable housing accounts for 17 percent of all housing in the EU as a whole. In Austria the sector represents 25 percent of the housing stock, while for Sweden and the U.K. these figures are respectively 20 and 18 percent. In many countries, it is the dominant form of rental housing (Whitehead and Scanlon, 2007). Yet, despite its importance, this segment of the housing market has hardly been investigated in the literature studying the economic effects of energy efficiency. Its size alone makes it an important sector in the energy efficiency abatement

\footnotetext{
${ }^{*}$ This chapter is co-authored with Andrea Chegut (MIT Center for Real Estate) and Piet Eichholtz (Maastricht University).

${ }^{2}$ These estimates are based on the average electricity and gas price statistics for the EU-27 as provided by Eurostat (2013) and the total electricity and gas consumption figures for the residential sector from Bertoldi et al. (2012). The average electricity and gas prices for households in the EU-27 in 2010 were respectively 17.3 and 5.7 Eurocent per KWh. In that year, the residential sector's electricity consumption was 843 billion KWh and its gas consumption 1,385 billion KWh. Multiplying these consumption figures with the average prices yields a total energy bill of approximately 225 billion euros in 2010 . We convert these consumption statistics to $\mathrm{kg}$ of $\mathrm{CO}_{2}$ emissions using a conversion factor of 0.445 for electricity and 0.184 for natural gas as documented by the (Carbon Trust, 2013).
} 
discussion.

There are a number of studies investigating the impact of energy performance on the economic performance of real estate, as measured by rental value, occupancy, and transaction price. For commercial real estate these studies generally find higher rents and transaction prices for environmentally certified buildings relative to conventional buildings, as well as higher and more stable occupancy rates. ${ }^{3}$

In the housing market, the studies concentrating on the financial performance of energy efficiency are fewer in number. Generally, these housing studies also document higher transaction prices for energy efficient dwellings, and find that the size of these price differences depend on the level of energy efficiency (Brounen and Kok, 2011; Cerin et al., 2014; Feige et al., 2013; Hyland et al., 2013). However, almost all of these housing studies take the owner-occupied housing sector into account, which is just one component of the housing market.

Affordable or public housing institutions face significant financial constraints in repaying the investments in energy efficiency related building improvements. This is caused by a splitincentive problem, where building owners invest in energy efficiency for buildings and tenants benefit from the resulting lower energy bill. In many countries, affordable housing sector rents are capped or limited in their increases, which makes the repayment of energy efficiency building investments through increased rents very difficult. These split incentives are a large problem also in the Netherlands, where the affordable housing sector's 2.4 million dwellings account for 31 percent of the total housing stock (Autoriteit Woningcorporaties, 2012) and where rent increases are strongly regulated.

However, Dutch affordable housing institutions also regularly sell dwellings from their stock to individual households, so an alternative method to get compensated for investments in environmental performance is through the realization of a possible increase in the value of their assets as a result of these improvements. To date, however, there is no evidence showing whether or not this is indeed the case, and given the uncertainty regarding this matter, affordable housing institutions may well underinvest in energy efficiency improvements of their dwellings. The main research question of this chapter is to shed light on this issue, by investigating whether energy efficiency is priced in affordable dwellings. We do that by examining a large sample of transactions of individual dwellings by Dutch affordable housing institutions.

To identify these improved energy efficient dwellings, we collect a sample of 17,835 transactions of affordable dwellings from the Netherlands' land registry, the Kadaster, in the period from 2008 until mid-2013 and link it to a database of Energy Performance Certificates (EPCs) maintained by the Netherlands Enterprise Agency (NEA).

The Energy Performance of Buildings Directive of 2003 stipulates the mandatory disclosure of the energy performance of buildings across all EU member states as of January 1, 2006. However, member states were granted an additional period of three years to implement the certification procedure. In the Netherlands all home owners were obliged to provide an EPC upon the sale of their house (older than 10 years) as of January 1, 2008. Nevertheless, due to opposition in the Dutch parliament, home owners were able to refrain from providing an EPC in case a waiver by both the selling and buying party was signed. Affordable housing institutions were given an additional year to implement the EPC to their housing portfolios as long as they

\footnotetext{
${ }^{3}$ See Bonde and Song (2014); Chegut et al. (2014); Eichholtz et al. (2010, 2013); Fuerst and McAllister (2011); Kok and Jennen (2012).
} 
ensured full labeling of all dwellings. ${ }^{4}$ So the incidence of transactions of housing with an EPC label went up substantially in 2008, but there were still many sales of unlabeled dwellings as well. As of 2015, Dutch law on this matter changed again, making the EPC label obligatory for all housing sales and rentals, without any exceptions.

We investigate the impact of energy efficiency on the transaction price per square meter in two ways. First, we estimate the value impact of energy labels in general, by comparing the transaction prices of labeled dwellings with those of non-labeled ones. About 64 percent of the dwellings in our sample have an Energy Performance Certificate, and we use the non-certified dwellings as the control sample.

Second, we study the energy labeled sample separately. This way, we can compare transactions of homes with high energy efficiency — those having an A or B label — with homes that are less energy efficient - having a label C through $G$, and it allows us to directly study the relationship between the energy performance index — on which the labels are based — and the prices of affordable homes.

In each of these settings, we analyze the relationship between energy efficiency and the transaction prices of affordable housing by employing a standard hedonic pricing model. This way, we control for building quality, location and general housing market conditions, as well as for thermal characteristics such as insulation quality.

We document that affordable dwellings with high-quality energy labels — Energy Performance Certificates of A or B - have higher transaction values than their otherwise comparable peers. Dwellings with an energy label of B or higher transact for 2.6 percent more compared to housing with label C or lower. Specifically, an A-labeled dwelling sells for 6.3 percent more, and a B-labeled dwelling for 2 percent more than an otherwise similar dwelling with a $\mathrm{C}$ label. This implies that the average affordable home with a $\mathrm{C}$ label in our sample would sell for almost EUR 9,700 more were it to transact as an A-labelled dwelling and for some EUR 3,000 more in case of a B label. These results suggest that although it may be difficult for affordable housing institutions to recover their investments in energy efficiency improvements directly through increased rents or reduced energy costs, they might be able to recover the investment, at least in part, at the time of sale.

In the remainder of this chapter, we will first briefly discuss related studies focusing on the impact of energy-efficiency in the residential real estate sector. Thereafter, we will describe the Dutch affordable housing market, discuss the data and data sources we use for the analysis, and provide some sample statistics. The following sections present the method and the empirical results. The chapter ends with a conclusion and a discussion of the policy implications of this study.

\subsection{The Housing Market and the Value of Energy Efficiency}

The literature regarding the value of energy efficiency in housing markets in Europe, Asia, and the U.S. generally finds that homes and apartments that are certified as having low primary

\footnotetext{
${ }^{4}$ See Brounen and Kok (2011) for a more extensive discussion on the measurement of the Energy Performance Certificate.
} 
energy demand have higher transaction prices and/or rents. However, there are variations across the studies in the type of certification studied, the extent of environmental performance measures linked to the certification and the magnitude of the premium for energy efficiency.

Early studies by Laquatra (1986) and Gilmer (1989) analyze the financial implications of the Minnesota Housing Finance Agency's Energy Efficient Housing Demonstration Program. Laquatra concludes that energy efficiency, measured by the thermal integrity factor, is capitalized in the transaction price of a demonstration home and Gilmer finds that home energy ratings have positive search benefits, which are larger in more diverse housing markets. Dinan and Miranowski (1989) study a sample of homes in Des Moines, and conclude that an efficiency improvement that would result in a USD 1 decrease in expenditures to maintain the home at 65 degrees Fahrenheit increases the expected transaction price by approximately USD 12.

Brounen and Kok (2011) analyze the impact of Energy Performance Certificates on the transaction prices of Dutch housing, employing a sample of homes sold in 2008 and 2009. Based on thermal quality, these homes are rated from $\mathrm{A}++$ to $\mathrm{G}$, with $\mathrm{A}++$ indicating highest energy efficiency. Dutch homes with an A label sell for 10.2 percent more than otherwise similar homes with a D label. The premiums for B and C labeled homes are 5.5 percent and 2.1 percent, respectively. Dwellings with a label inferior to $\mathrm{D}$ trade at a discount.

Cerin et al. (2014) investigate whether the energy efficiency of homes in Sweden contributes to the transaction price. The authors study housing transactions from 2009 and 2010, and find that only the most energy efficient homes command a small price premium. An decrease in energy consumption of 1 percent for the most energy efficient homes yields a transaction price increase of 0.03 percent.

Hyland et al. (2013) perform a similar study for transactions in the Irish housing market, and also include housing rents in their analysis. The authors study the relationship between Ireland's Building Energy Rating (BER) and transaction prices and rental rates for the period from 2008 to 2012. Their transaction price results are comparable to those found by Brounen and Kok (2011), both in direction and in terms of magnitude. Moreover, the authors find that energy efficiency matters more when selling conditions are worse and dwellings are smaller. For rents, the authors document a higher rental value of 1.9 percent for an A labeled dwelling compared to a D label. Surprisingly, the rental premium for a B labeled dwelling is 4.2 percent. Rental units with $\mathrm{E}, \mathrm{F}$ and $\mathrm{G}$ labels have rental discounts.

Feige et al. (2013) study the effect of different sustainability attributes on the rental value of Swiss residential units in 2009. They employ a broad range of sustainability criteria, and find that the environmental performance of dwellings is positively related to rent levels. Especially attributes that improve water efficiency, the health and comfort level, and the safety and security of a building contribute positively to the rent level. Interestingly, the energy efficiency of a dwelling is negatively related to rent levels. The authors argue that this may be caused by the common Swiss practice of incorporating the energy costs in the rent.

Recently, Copiello (2015) has performed a case study of one refurbished affordable apartment building in Turin, Italy. The refurbishment has increased the building's environmental performance, improving its insulation, heating systems and other installations. The author finds that rents in the building have gone up substantially, so providing a market-based incentive towards improvements in environmental performance in affordable housing.

In Asia, Yoshida and Sugiura (2013) assess the impact of certification under the Tokyo Green 
Building Program on the transaction value of residential real estate. ${ }^{5}$ The authors employ a sample of condominiums sold in the period from 2002 to 2009, and document that new certified units sell at a substantial discount of approximately 11 to 12 percent compared to non-certified apartment units. However, certified dwellings do sell at a premium in the secondary market.

Deng et al. (2012) investigate the effect of Green Mark certification on the transaction price of residential housing in Singapore. ${ }^{6}$ The authors find that certified dwellings sell at a 4 to 6 percent premium. The observed premium varies significantly across the certification categories, with Platinum rated buildings commanding the highest premium -14 percent. The transaction price for buildings with the lowest type of certification does not differ significantly from non-certified buildings.

In China, rating systems for the environmental performance of buildings are not formally adopted. Therefore, a study by Zheng et al. (2012) evaluates the impact of "marketing greenness" on the transaction price of housing in Beijing. The authors construct a Google Green Index based on the search rank of housing complexes with respect to their green features for the period from 2003 to 2008 to test the relationship between the initial asking price and the "greenness" of these properties. The authors document that the greenest building in the sample sells at a 17.7 percent premium compared to the least green building.

Dastrup et al. (2012) focus on the impact of solar panels on the transaction prices of owneroccupied homes in California, and find that these are capitalized in the transaction value at a 3.6 to 4.0 percent premium, corresponding to a predicted increase in transaction value of about USD 22,500. The premium is higher in streets with fewer solar-powered homes.

Kahn and Kok (2014) assess the impact of green home certification on transaction values in California. The authors employ a dataset of homes sold between 2007 and 2012. Homes with a green certificate transact for 2 to 4 percent more compared to otherwise similar homes, and energy efficiency is more important for dwellings located in a hotter climate or in districts with higher electricity prices.

The existing findings in Europe, Asia and America suggest that energy efficiency commands a premium in residential sales and rents. However, with the exception of the case study of Copiello (2015), none of these studies involve affordable housing. This implies a void in understanding the role of energy efficiency in the housing stock, especially for Europe, where affordable housing institutions play such a prominent role in the residential sector. Moreover, Schaffrin and Reibling (2015) show that low-income households spend a relatively large share of their income on utility costs, which could imply that possible value effects of investments in the environmental performance in housing are large in affordable housing.

To help fill this gap in the literature, we focus on energy efficient affordable housing. We measure the financial performance of dwelling energy efficiency in the European country with the highest number of affordable dwellings per capita: the Netherlands.

\footnotetext{
${ }^{5}$ The Tokyo Green Building Program scores various environmental factors of different types of real estate. The score takes into account the energy efficiency, resource efficiency, use of energy efficient equipment, life span, planting and the mitigation of the heat island phenomenon of a building.

${ }^{6}$ Singapore's Green Mark program assesses the environmental attributes of buildings. The program evaluates the energy and water efficiency, the quality of the indoor environment and the overall environmental impact of real estate.
} 


\subsection{The Dutch Affordable Housing Market}

In relative terms, the Netherlands has by far the largest affordable housing sector of all the countries in Europe: almost one out of three households live in a dwelling owned by an affordable housing institution (Aedes, 2013b). Another yardstick of prominence is that the 381 Dutch affordable housing institutions together own approximately 2.4 million dwellings (Autoriteit Woningcorporaties, 2013). Together, they dwarf Dutch institutional investors in housing, who own a combined portfolio of only 136,000 dwellings (Finance Ideas, 2014).

Hence, to scale up investments in the environmental performance of homes in the Netherlands, affordable housing institutions are a logical starting point. That holds for other European Union countries as well. The affordable housing sector in other European countries is substantially smaller, but is still approximately 17 percent of the total housing stock (Whitehead and Scanlon, 2007). ${ }^{7}$

With an affordable housing sector this large, it is inevitable that these institutions also cater to middle- and lower-middle income groups besides their core client base, i.e. families with the lowest incomes. The Dutch affordable housing stock reflects this. With an average value of EUR 149,000 in 2012 (Aedes, 2013a), the dwellings they own are only 36 percent less valuable than an average owner-occupied home. The average quality of these dwellings is also underlined by the fact that some 42 percent are single-family homes (Aedes, 2013a), where affordable housing in most other countries is associated with projects, i.e. high rise apartment buildings, often located in the less attractive parts of cities. Only 11 percent of the Dutch affordable housing stock would fit that description, whereas the remainder consists of multi-family housing with 4 floors at most (Aedes, 2013a), as well as some senior housing.

In 2012, Dutch affordable housing institutions charged an average rent of EUR 434 per month excluding utility costs (Aedes, 2013a). This is lower than the market rent in most Dutch regions, so households that live in a dwelling owned by an affordable housing landlord tend to stay there, and many affordable housing institutions have waiting lists for their product, especially in the big cities and in the Randstad region in the western part of the country. ${ }^{8}$

Almost all households living in dwellings owned by affordable housing institutions are eligible for rent protection. This implies that the rent of an existing contract can only be increased by a percentage set by the government, usually inflation plus a mark-up. Even when an owner does a major renovation, improving the quality of a dwelling, or when an owner invests in energy efficiency, thereby lowering the utility costs for the tenant, the rent on existing contracts cannot be increased to compensate the owner for the investment expense. ${ }^{9}$ This makes it difficult to recoup an investment in the environmental performance through improved rental cash flows,

\footnotetext{
${ }^{7}$ This number is based on a survey of affordable housing institutions in Austria, Denmark, England, France, Germany, Hungary, Ireland, the Netherlands, and Sweden performed by Whitehead and Scanlon (2007).

${ }^{8}$ The Randstad is a region in the Netherlands consisting of the nation's four largest cities, Amsterdam, Rotterdam, the Hague and Utrecht, as well as the smaller cities lying between them. In total, some 41 percent of the total Dutch population lives in this area. Retrieved from: http://www.cbs.nl/en-GB/ menu/methoden/toelichtingen/alfabet/r/randstad-region.htm.

${ }^{9}$ Only if at least 70 percent of households living in a housing complex agree with a rent increase associated with a refurbishment can the rent be increased for all of the existing tenants in that complex under Dutch law. This number is hard to accomplish in practice, and even if successful, this negotiation process usually does not provide additional rental cash flows that suffice to recoup the investment costs borne by the owner.
} 
and it creates a disincentive for the diffusion of energy efficient affordable housing.

However, affordable housing institutions may be able to partly recover these investments if they sell part of their housing stock in the market. Most European countries' affordable housing institutions are not allowed to do that, so the sale of affordable dwellings is quite rare. But in the Netherlands, affordable housing institutions are allowed and even stimulated to gradually sell dwellings from their stock (Binnenlandse Zaken en Koninkrijksrelaties, 1992). This policy allows affordable housing institutions to sustain a steady cash inflow, which they can reinvest in new construction and in the renovation of their remaining housing stock, thereby realizing their ambitions regarding its quality and environmental performance. The policy also aims to foster private home ownership among low- and middle-income households. This unique regulatory environment in the Netherlands creates an ideal setting to analyze whether consumers in affordable housing value energy efficiency investments.

\subsection{Data and Descriptive Statistics}

\subsubsection{Data}

In order to investigate the impact of energy efficiency on the transaction value of affordable housing empirically we combine various data sources. For every year between 2008 and 2013 we retrieve the universe of affordable housing institutions active in the Netherlands from the Autoriteit Woningcorporaties. ${ }^{10}$ Using the affordable housing institutions' original listed name as obtained from the Autoriteit Woningcorporaties, we gather information regarding the housing transactions by each institution in the database of the Dutch land registry, the Kadaster. This database provides the exact location of each transacted dwelling, as well as its transaction price, and a set of dwelling characteristics. This matching exercise leads to the identification of 44,725 transactions by Dutch affordable housing institutions in the period from 2008 up to mid-2013.

The dwelling quality information provided by the Kadaster is rather limited in scope, and in order to get a more comprehensive set of dwelling characteristics we match the Autoriteit Woningcorporaties and Kadaster data with data from the Dutch Realtors Association (NVM). The NVM documents detailed information for every home that is sold by an associated realtor. This enables us to extensively control for the impact of quality differences throughout our analyses. Based on the location of each home - by employing the unique combination of the building's postcode, house number, and house number addition - we combine the information from the NVM database with the set of transactions supplied by the Kadaster. This leads to a total of 25,785 matched transactions.

Further information on the Energy Performance Certificate (EPC) and energy performance index of each home is obtained from the NEA, which is part of the Dutch Ministry of Economic Affairs. This agency facilitates the energy performance certification of existing and new buildings in the Netherlands.

\footnotetext{
${ }^{10}$ The Autoriteit Woningcorporaties is the supervisory body to which all Dutch affordable housing institutions report. We use the overview of institutions they maintain to ensure complete coverage in the earlier years of our sample period since many Dutch affordable housing institutions merged over the last decade: the affordable housing market consolidated from 430 institutions in 2008 to 381 institutions in 2012.
} 
Incomplete information on quality characteristics across transactions limits the sample, and our final sample includes a total of 17,835 transactions. ${ }^{11}$ Of these dwellings, 11,411 have an energy label, and the other 6,424 observations serve as the control sample. ${ }^{12}$

\subsubsection{Descriptive Statistics}

Table 6.1 provides information on the total sample, and on the sub-samples of non-labeled and labeled dwellings, with the latter specified by label quality. The first column of Table 6.1 shows that the average home in the sample sells for some EUR 1,760 per square meter, with an average size of approximately 90 square meters divided over four rooms. Most of the homes are either apartments or duplexes, and these two types account for about 76 percent of the total sample. Most of the homes in the full sample have been constructed between 1961 and 1990. The quality of exterior (interior) maintenance is rated as medium or better for 96.1 (93.6) percent of the observations.

Concerning the thermal quality characteristics, almost 90 percent of the homes use a central heating system. ${ }^{13}$ The insulation quality is on average quite poor with 73 percent of the observations displaying a low insulation quality: less than two types of insulation. Less than 10 percent of the homes have four or more types of insulation.

Energy performance certificates were initially not completely mandatory in the Netherlands. Due to societal resistance against the EPC label, the initial Dutch legislation pertaining to the matter allowed home buyers to sign a waiver that obviated the seller's obligation to provide an EPC with the home. This explains why we observe both labeled and non-labeled dwellings in our sample.

The remaining columns of Table 6.1 provide dwelling characteristics across label categories within the labeled sample. Based on the transaction price per square meter the largest difference occurs between label categories A to B and C to $G$. The average home with energy label B or higher transacts for some EUR 400-500 per square meter more than the average home with label $\mathrm{C}$ or lower. The distribution of dwelling types shows that apartments tend to have a higher energy label. Duplexes and semi-duplexes are more strongly represented in the lower quality label categories. Not very surprisingly, homes with a higher quality energy label tend to be constructed more recently.

Comparing dwelling sizes across label quality groups shows no systematic differences when looking at floor surface area, but homes with the best environmental quality have a somewhat lower number of rooms.

\footnotetext{
${ }^{11}$ Due to non-consistent information on the transaction price between the Kadaster and NVM databases the sample reduces to 22,017 observations. Finally, missing dwelling quality characteristics and ensuring that every postcode area has at least one labeled building further reduces the sample to 17,835 observations.

${ }^{12}$ The Dutch Realtors Association (NVM) is better represented in the urban areas of the Netherlands. To ensure that our results do not suffer from selection bias we have also estimated the results presented in Table 6.2 and 6.3 for the larger sample provided by the Dutch Land Registry (Kadaster), using a reduced set of covariates. The results from these robustness tests are in line with the effects we present in Table 6.2 and 6.3 .

${ }^{13}$ The central heating systems in the Netherlands are mostly gas-powered. The gas/coal heating variable in the table indicates the presence of a gas or coal stove that directly heats living spaces.
} 


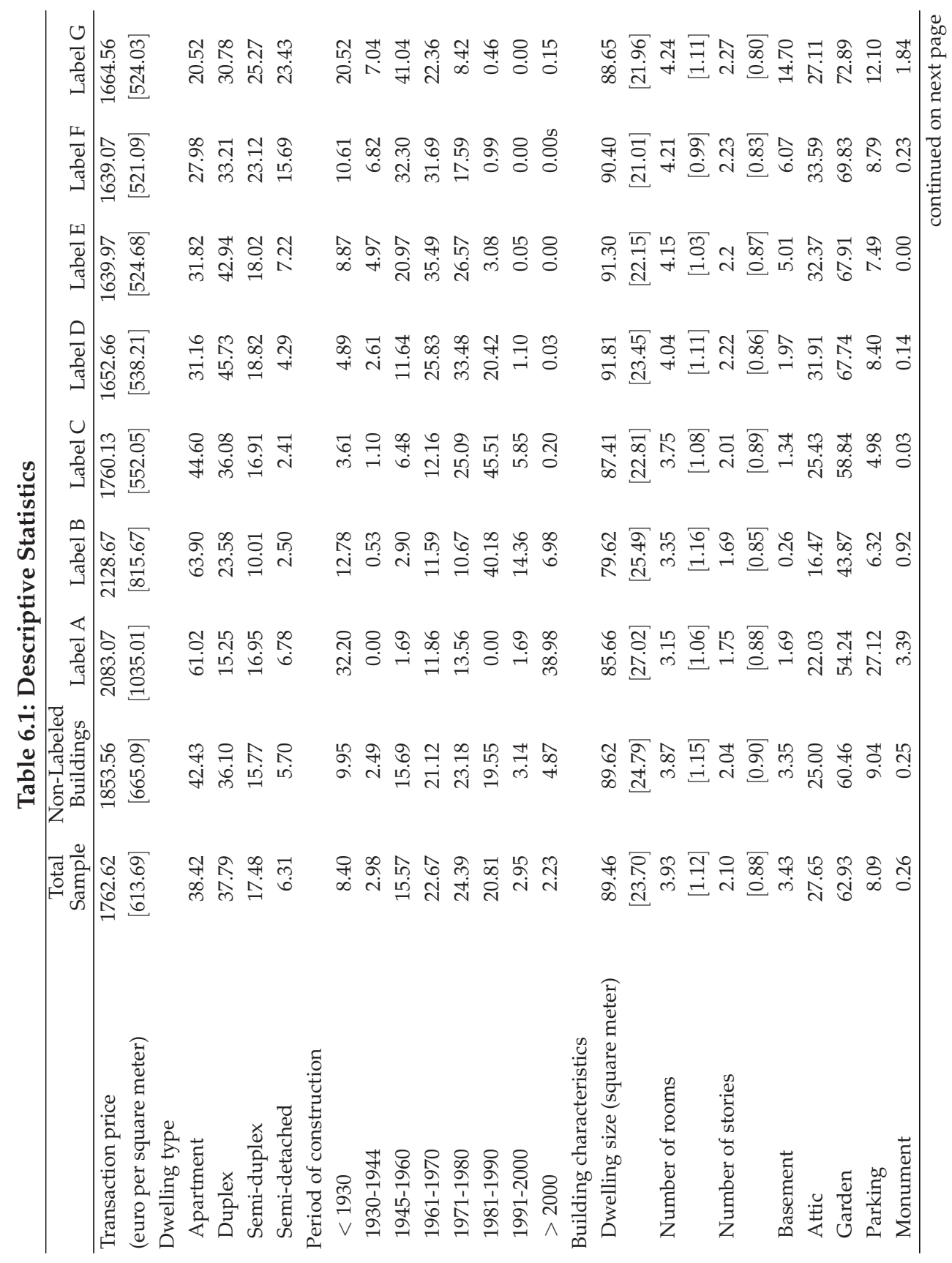




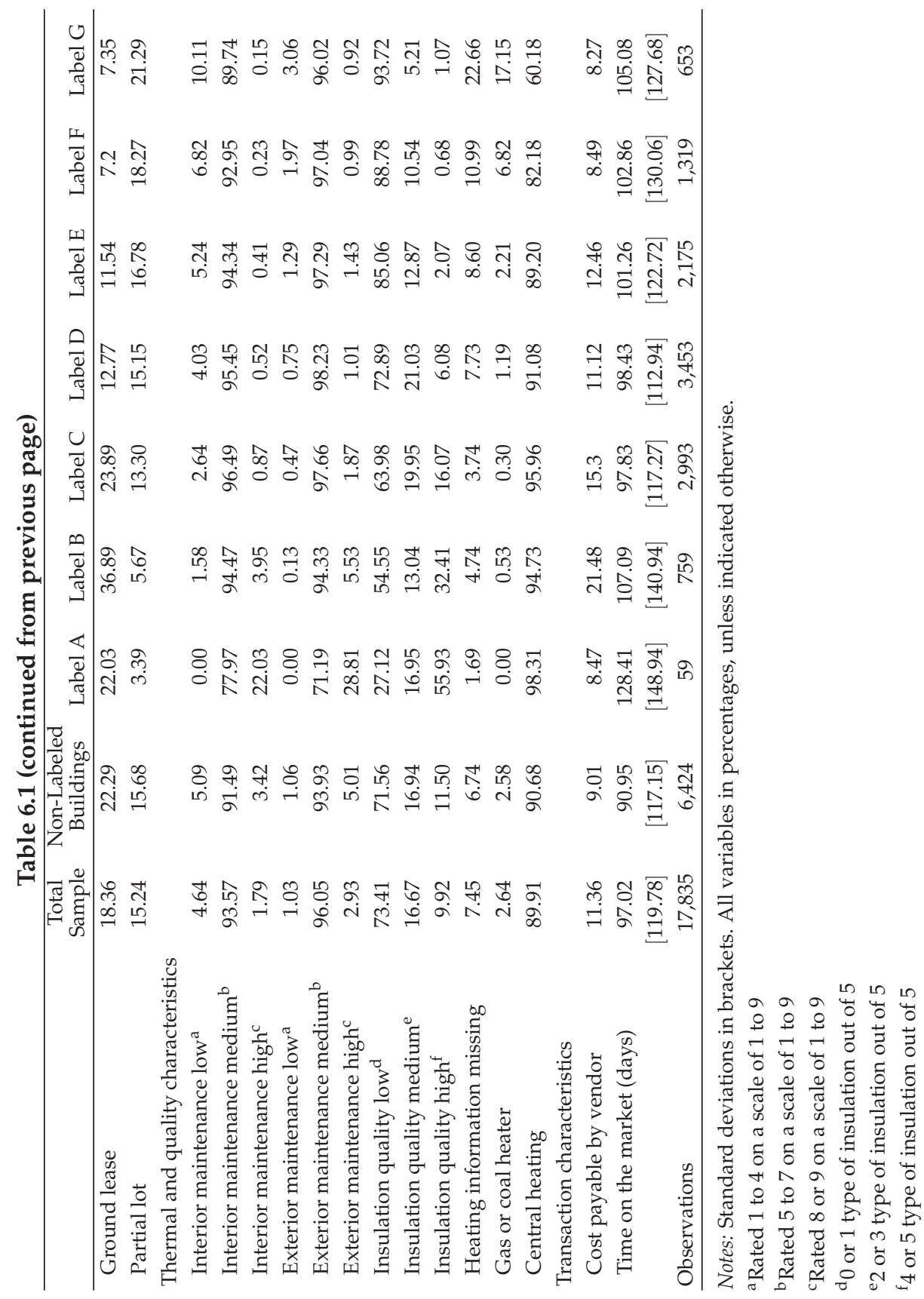


Figure 6.1: Distribution of Energy Performance Certificates

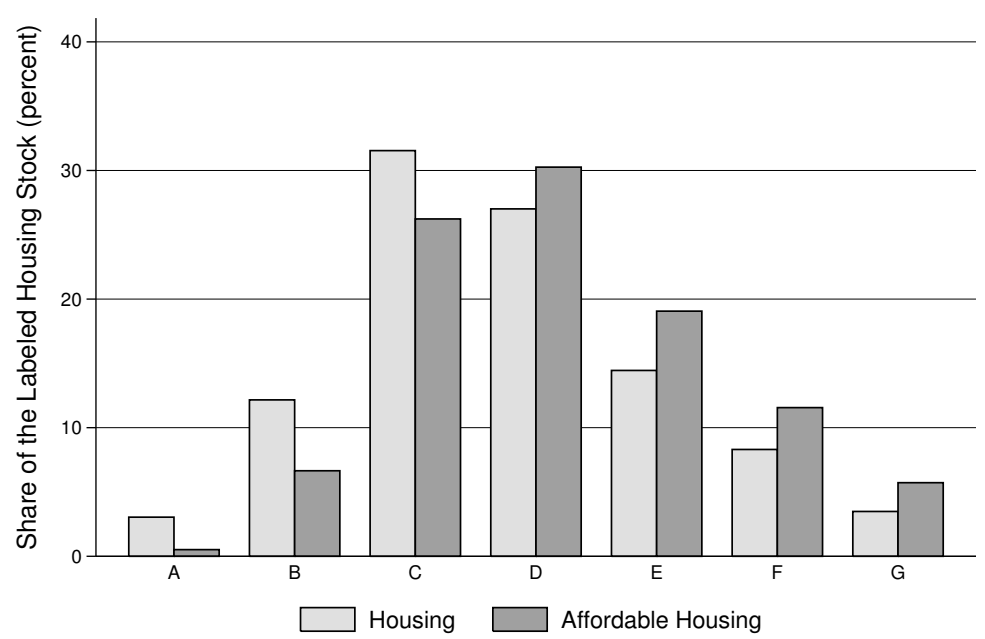

Notes: The above figure displays the average share of the different energy performance certificates for the Netherlands over the 2009 to 2013 time period to the distribution of label categories in our sample of sold affordable housing dwellings. The figures for the national distribution are obtained from: http://www. senternovum.databank.nl.

As expected, thermal characteristics do differ substantially across label categories. Homes with a higher energy label more often use a central heating system, and have higher insulation quality. On average, more than 55 percent of the homes with an A label have a high insulation quality while this is the case for some one percent of homes with a G label. The quality of the interior and exterior maintenance further confirms this.

The distribution of the energy label reveals that label C, D, and E are the largest label categories, cumulatively representing some 75 percent of the sample. Furthermore, less than one percent of the affordable homes sold have an A label compared to a national average of more than three percent. ${ }^{14}$ Given that two thirds of the labeled sample consists of lower quality homes with energy label D or lower there is still a lot to gain from investments in energy efficient retrofits.

Figure 6.1 compares the distribution of the label categories in our sample to the national average over the same time period. In general, comparing the overall label distribution for our affordable housing sample to the national average shows that our sample has a slightly worse average label compared to the national figures.

\footnotetext{
${ }^{14}$ The national figures and distribution for all Dutch homes are available from the NEA, www. senternovem. databank.nl.
} 


\subsection{Method}

To investigate how energy efficiency influences the transaction price of affordable housing, we employ a standard hedonic real estate valuation framework (Rosen, 1974). We estimate a semi-log hedonic equation, relating the log of the transaction price per dwelling to energy efficiency, building characteristics and location, and time:

$$
\log P_{i}=\alpha+\delta G_{i}+\beta X_{i}+\gamma T+\epsilon_{i}
$$

In our base model in Equation (6.1), the dependent variable is the logarithm of the transaction price $P$ per square meter of home $i$. The variable of interest of the model is $G$, which is a dummy variable with a value of one if building $i$ has an energy label and zero otherwise. $\delta$ is thus the average premium (in percent) estimated for a labeled dwelling relative to non-labeled dwellings. In alternative specifications of the model, $G$ denotes the quality of the energy label or the level of the energy performance index on which the EPC labels are based. $X$ is a vector of hedonic characteristics (e.g. size, age, thermal and quality characteristics) and location (the four-digit postcode area the home is located in) of home $i^{15}$ We control for macro-economic factors using year-quarter fixed effects $T$. Last, $\alpha, \beta$ and $\gamma$ are estimated coefficients for the control variables, and $\epsilon$ is an error term.

In this model specification we cannot entirely rule out the possibility that unobserved quality differences between the homes in our labeled and non-labeled sample and within the different label categories determine the observed capitalization differences. For example, affordable housing institutions might choose to bundle high energy efficiency with other quality characteristics such as nicer kitchens or bathrooms. Nevertheless, by extensively controlling for quality characteristics on the building level, such as the level of interior and exterior maintenance we reduce this possibility as much as possible.

\subsection{Results}

We first assess the value of energy labels in general, distinguishing low-quality from highquality labels. After measuring the relative value of energy labels in the full sample we further investigate the effect of dwelling energy efficiency by inspecting a subset of labeled dwellings only.

\subsubsection{The Value of Energy Performance Certificates in Affordable Housing}

Table 6.2 displays the results of our regression analysis of the full sample using the base model presented in Equation (6.1). All specifications presented in Table 6.2 use the natural logarithm of the transaction price per square meter as the dependent variable. This dependent variable is related to an extensive set of hedonic and location characteristics, as well as macro-economic

\footnotetext{
${ }^{15}$ We also tested different location fixed effects, controlling for location at the municipality level or the six-digit postcode level. The results are consistent and robust. Similar location fixed effects have been employed in previous research by Kok and Jennen (2012).
} 
factors that serve as control variables in the specification. ${ }^{16}$ The models in Table 6.2 explain about 90 percent of the variation in the transaction value of the homes in the sample, which compares favorably to what is typically found in the literature employing hedonic valuation models for housing.

The first column in Table 6.2 relates the transaction value of the buildings in the sample to the most important building characteristics, location, and macro-economic factors. The location controls are based on the four-digit zip code; macro-economic trends are controlled for using year-quarter fixed effects.

Results for the control variables are mostly in line with the literature. Our main interest in Column (1) lies in the coefficient for the presence of an EPC label. Interestingly and somewhat surprisingly, an EPC label in general has a negative impact of 0.8 percent on the transaction price per square meter. This effect may stem from the fact that most of our EPC labeled sample consists of homes with a relatively high primary energy demand, having an EPC label of C or less.

The second column of Table 6.2 controls more extensively for the quality characteristics of the homes in our sample and takes the thermal characteristics of the dwelling into account as well. The coefficients of the other control variables, both in terms of sign, magnitude and statistical significance, are in line with the previous specification. The negative labeling effect decreases in this more elaborate specification to -0.7 percent.

The results show that maintenance and thermal characteristics are priced, although the inclusion of these new variables does not push the explanatory power of the model beyond the 0.90 attained in the first specification. Both interior and exterior maintenance are significant determinants of the transaction price, but the former has a much larger effect. Dwellings with the best interior maintenance sell for 12.5 percent more than the worst, while the effect for best external maintenance is only 3.9 percent.

The insulation quality of a home also contributes statistically significantly to transaction values. Compared to homes with the lowest insulation quality, homes with two or more types of insulation experience a gradually increasing premium. Relative to homes having low insulation quality, fully insulated homes sell at a premium of 1.7 percent. When it comes to heating systems, homes with a central heating system transact for approximately 5.7 percent more as compared to homes with a gas or coal heating system in place.

The third and fourth columns of Table 6.2 use similar specifications as discussed before, but cluster housing with high energy efficiency, those having labels A or B, versus housing with low energy efficiency, labels $C$ to $G$, to verify our previous findings. The transaction price for housing with an A or B label is 1.3 percent higher as compared to non-labeled housing. Conversely, homes with a relatively high primary energy demand, label categories $C$ to $G$, sell at a discount of 0.8 percent. Therefore, the negative effect of EPC labels in general as observed in the first and second column of Table 6.2 stems from dwellings with a label of $C$ or worse.

\footnotetext{
${ }^{16}$ The strong similarity of the treatment and control samples of labeled and non-labeled homes allows us to compare these samples directly. Nevertheless, we also applied propensity score weighting in all the specifications, and the results are robust.
} 
Table 6.2: Transaction Value and Energy Performance Certificates

\begin{tabular}{|c|c|c|c|c|}
\hline & $(1)$ & $(2)$ & (3) & $(4)$ \\
\hline Energy label (1=yes) & $\begin{array}{c}-0.008^{* * *} \\
{[0.003]}\end{array}$ & $\begin{array}{c}-0.007^{* * *} \\
{[0.003]}\end{array}$ & & \\
\hline Energy label A or B (1=yes) & & & $\begin{array}{l}0.013^{* *} \\
{[0.006]}\end{array}$ & \\
\hline Energy label C to G (1=yes) & & & $\begin{array}{c}-0.008^{* * *} \\
{[0.003]}\end{array}$ & \\
\hline \multicolumn{5}{|l|}{ Energy performance certificate ( $1=y e s)$} \\
\hline Label A & & & & $\begin{array}{l}0.056^{* * *} \\
{[0.017]}\end{array}$ \\
\hline Label B & & & & $\begin{array}{c}0.011^{*} \\
{[0.006]}\end{array}$ \\
\hline Label C & & & & $\begin{array}{c}-0.002 \\
{[0.003]}\end{array}$ \\
\hline Label D & & & & $\begin{array}{c}-0.008^{* * *} \\
{[0.003]}\end{array}$ \\
\hline Label E & & & & $\begin{array}{c}-0.014^{* * *} \\
{[0.004]}\end{array}$ \\
\hline Label F & & & & $\begin{array}{c}-0.016^{* * *} \\
{[0.005]}\end{array}$ \\
\hline Label G & & & & $\begin{array}{c}-0.008 \\
{[0.007]}\end{array}$ \\
\hline \multicolumn{5}{|l|}{ Building characteristics } \\
\hline Log dwelling size (square meter) & $\begin{array}{c}-0.580^{* * *} \\
{[0.011]}\end{array}$ & $\begin{array}{c}-0.587^{* * *} \\
{[0.011]}\end{array}$ & $\begin{array}{c}-0.586^{* * *} \\
{[0.011]}\end{array}$ & $\begin{array}{c}-0.587^{* * *} \\
{[0.011]}\end{array}$ \\
\hline Number of rooms & $\begin{array}{l}0.023^{* * *} \\
{[0.002]}\end{array}$ & $\begin{array}{l}0.024^{* * *} \\
{[0.002]}\end{array}$ & $\begin{array}{l}0.024^{* * *} \\
{[0.002]}\end{array}$ & $\begin{array}{l}0.025^{* * *} \\
{[0.002]}\end{array}$ \\
\hline Basement (1=yes) & $\begin{array}{c}0.028^{*} \\
{[0.015]}\end{array}$ & $\begin{array}{l}0.030^{* *} \\
{[0.014]}\end{array}$ & $\begin{array}{c}0.031^{* *} \\
{[0.014]}\end{array}$ & $\begin{array}{l}0.031^{* *} \\
{[0.014]}\end{array}$ \\
\hline Attic (1=yes) & $\begin{array}{r}-0.002 \\
{[0.004]}\end{array}$ & $\begin{array}{c}-0.002 \\
{[0.004]}\end{array}$ & $\begin{array}{c}-0.001 \\
{[0.004]}\end{array}$ & $\begin{array}{c}-0.001 \\
{[0.004]}\end{array}$ \\
\hline Garden (1=yes) & $\begin{array}{l}0.031^{* * *} \\
{[0.004]}\end{array}$ & $\begin{array}{l}0.029^{* * *} \\
{[0.004]}\end{array}$ & $\begin{array}{l}0.029^{* * *} \\
{[0.004]}\end{array}$ & $\begin{array}{l}0.029^{* * *} \\
{[0.004]}\end{array}$ \\
\hline Parking (1=yes) & $\begin{array}{l}0.055^{* * *} \\
{[0.005]}\end{array}$ & $\begin{array}{l}0.053^{* * *} \\
{[0.005]}\end{array}$ & $\begin{array}{l}0.053^{* * *} \\
{[0.005]}\end{array}$ & $\begin{array}{l}0.053^{* * *} \\
{[0.005]}\end{array}$ \\
\hline Monument (1=yes) & $\begin{array}{l}0.137^{* * *} \\
{[0.041]}\end{array}$ & $\begin{array}{l}0.141^{* * *} \\
{[0.037]}\end{array}$ & $\begin{array}{l}0.138^{* * *} \\
{[0.038]}\end{array}$ & $\begin{array}{l}0.137^{* * *} \\
{[0.037]}\end{array}$ \\
\hline Ground lease (1=yes) & $\begin{array}{c}-0.007 \\
{[0.011]}\end{array}$ & $\begin{array}{r}-0.010 \\
{[0.011]}\end{array}$ & $\begin{array}{c}-0.010 \\
{[0.011]}\end{array}$ & $\begin{array}{c}-0.010 \\
{[0.011]}\end{array}$ \\
\hline Partial lot (1=yes) & $\begin{array}{c}-0.004 \\
{[0.003]}\end{array}$ & $\begin{array}{r}-0.004 \\
{[0.003]}\end{array}$ & $\begin{array}{r}-0.004 \\
{[0.003]}\end{array}$ & $\begin{array}{r}-0.004 \\
{[0.003]}\end{array}$ \\
\hline \multicolumn{5}{|l|}{ Number of stories ${ }^{\mathrm{a}}(1=\mathrm{yes})$} \\
\hline One story & $\begin{array}{c}-0.036^{* *} \\
{[0.017]}\end{array}$ & $\begin{array}{c}-0.037^{* *} \\
{[0.017]}\end{array}$ & $\begin{array}{c}-0.037^{* *} \\
{[0.017]}\end{array}$ & $\begin{array}{c}-0.036^{* *} \\
{[0.017]}\end{array}$ \\
\hline Two stories & $\begin{array}{r}-0.006 \\
{[0.017]}\end{array}$ & $\begin{array}{r}-0.008 \\
{[0.017]}\end{array}$ & $\begin{array}{c}-0.007 \\
{[0.017]}\end{array}$ & $\begin{array}{c}-0.007 \\
{[0.017]}\end{array}$ \\
\hline Three stories & $\begin{array}{c}-0.009 \\
{[0.017]}\end{array}$ & $\begin{array}{r}-0.014 \\
{[0.016]}\end{array}$ & $\begin{array}{r}-0.014 \\
{[0.016]}\end{array}$ & $\begin{array}{c}-0.013 \\
{[0.016]}\end{array}$ \\
\hline
\end{tabular}


Table 6.2: continued from previous page

\begin{tabular}{|c|c|c|c|c|}
\hline & $(1)$ & $(2)$ & (3) & (4) \\
\hline \multicolumn{5}{|l|}{ Dwelling type ${ }^{\mathrm{b}}$ (1=yes) } \\
\hline \multirow[t]{2}{*}{ Apartment } & $0.071^{* * *}$ & $0.075^{* * *}$ & $0.076^{* * *}$ & $0.076^{* * *}$ \\
\hline & {$[0.009]$} & {$[0.009]$} & {$[0.009]$} & {$[0.009]$} \\
\hline \multirow{2}{*}{ Duplex } & $0.109^{* * *}$ & $0.113^{* * *}$ & $0.114^{* * *}$ & $0.114^{* * *}$ \\
\hline & {$[0.009]$} & {$[0.009]$} & {$[0.009]$} & {$[0.009]$} \\
\hline \multirow[t]{2}{*}{ Semi-duplex } & $0.173^{* * *}$ & $0.182^{* * *}$ & $0.182^{* * *}$ & $0.183^{* * *}$ \\
\hline & {$[0.012]$} & {$[0.012]$} & {$[0.012]$} & {$[0.012]$} \\
\hline \multicolumn{5}{|c|}{ Thermal and quality characteristics (1=yes) } \\
\hline \multirow[t]{2}{*}{ Interior maintenance medium ${ }^{c}$} & & $0.039^{* * *}$ & $0.039^{* * *}$ & $0.039^{* * *}$ \\
\hline & & {$[0.005]$} & {$[0.005]$} & {$[0.005]$} \\
\hline \multirow[t]{2}{*}{ Interior maintenance high ${ }^{\mathrm{d}}$} & & $0.125^{* * *}$ & $0.124^{* * *}$ & $0.124^{* * *}$ \\
\hline & & {$[0.014]$} & {$[0.013]$} & {$[0.013]$} \\
\hline \multirow[t]{2}{*}{ Exterior maintenance medium ${ }^{c}$} & & $0.030^{* *}$ & $0.030^{* *}$ & $0.030^{* *}$ \\
\hline & & {$[0.013]$} & {$[0.013]$} & {$[0.013]$} \\
\hline \multirow[t]{2}{*}{ Exterior maintenance high ${ }^{\mathrm{d}}$} & & $0.039^{* *}$ & $0.038^{* *}$ & $0.038^{* *}$ \\
\hline & & {$[0.016]$} & {$[0.016]$} & {$[0.016]$} \\
\hline \multirow[t]{2}{*}{ Insulation quality medium ${ }^{\mathrm{e}}$} & & $0.007^{* *}$ & $0.007^{* *}$ & $0.006^{*}$ \\
\hline & & {$[0.003]$} & {$[0.003]$} & {$[0.003]$} \\
\hline \multirow[t]{2}{*}{ Insulation quality high ${ }^{\mathrm{f}}$} & & $0.017^{* * *}$ & $0.016^{* * *}$ & $0.015^{* * *}$ \\
\hline & & {$[0.005]$} & {$[0.005]$} & {$[0.005]$} \\
\hline \multirow[t]{2}{*}{ Heating information missingg } & & $0.030^{* * *}$ & $0.030^{* * *}$ & $0.029^{* * *}$ \\
\hline & & {$[0.007]$} & {$[0.007]$} & {$[0.007]$} \\
\hline \multirow[t]{2}{*}{ Central heatingg } & & $0.057^{* * *}$ & $0.057^{* * *}$ & $0.056^{* * *}$ \\
\hline & & {$[0.007]$} & {$[0.007]$} & {$[0.007]$} \\
\hline \multicolumn{5}{|l|}{ Period of construction ${ }^{\mathrm{h}}(1=\mathrm{yes})$} \\
\hline \multirow[t]{2}{*}{$1930-1944$} & $-0.049^{* * *}$ & $-0.045^{* * *}$ & $-0.044^{* * *}$ & $-0.043^{* * *}$ \\
\hline & {$[0.013]$} & {$[0.014]$} & {$[0.014]$} & {$[0.014]$} \\
\hline \multirow[t]{2}{*}{$1945-1960$} & $-0.033^{* *}$ & $-0.027^{* *}$ & $-0.026^{* *}$ & $-0.026^{*}$ \\
\hline & {$[0.014]$} & {$[0.013]$} & {$[0.013]$} & {$[0.013]$} \\
\hline \multirow[t]{2}{*}{$1961-1970$} & $-0.037^{* * *}$ & $-0.034^{* * *}$ & $-0.033^{* * *}$ & $-0.033^{* * *}$ \\
\hline & {$[0.012]$} & {$[0.012]$} & {$[0.011]$} & {$[0.011]$} \\
\hline \multirow[t]{2}{*}{$1971-1980$} & $-0.022^{*}$ & $-0.022^{* *}$ & $-0.021^{*}$ & $-0.022^{* *}$ \\
\hline & {$[0.012]$} & {$[0.011]$} & {$[0.011]$} & {$[0.011]$} \\
\hline \multirow[t]{2}{*}{$1981-1990$} & 0.011 & 0.010 & 0.010 & 0.008 \\
\hline & {$[0.011]$} & {$[0.010]$} & {$[0.010]$} & {$[0.010]$} \\
\hline \multirow[t]{2}{*}{$1991-2000$} & $0.106^{* * *}$ & $0.091^{* * *}$ & $0.090^{* * *}$ & $0.088^{* * *}$ \\
\hline & {$[0.015]$} & {$[0.015]$} & {$[0.015]$} & {$[0.015]$} \\
\hline \multirow[t]{2}{*}{$>2000$} & $0.217^{* * *}$ & $0.175^{* * *}$ & $0.174^{* * *}$ & $0.173^{* * *}$ \\
\hline & [0.017] & [0.016] & {$[0.016]$} & {$[0.016]$} \\
\hline \multicolumn{5}{|l|}{ Transaction characteristics } \\
\hline \multirow[t]{2}{*}{ Cost payable by vendor (1=yes) } & $0.024^{* * *}$ & $0.023^{* * *}$ & $0.022^{* * *}$ & $0.022^{* * *}$ \\
\hline & {$[0.004]$} & {$[0.004]$} & {$[0.004]$} & {$[0.004]$} \\
\hline Time on the market (days) & $0.000^{* *}$ & $0.000^{* *}$ & $0.000^{* *}$ & $0.000^{* *}$ \\
\hline & {$[0.000]$} & {$[0.000]$} & {$[0.000]$} & {$[0.000]$} \\
\hline Location fixed effects & yes & yes & yes & yes \\
\hline Time fixed effects (year-quarter) & yes & yes & yes & yes \\
\hline
\end{tabular}


Table 6.2: continued from previous page

\begin{tabular}{lcccc}
\hline & \multicolumn{1}{c}{$(1)$} & \multicolumn{1}{c}{$(2)$} & \multicolumn{1}{c}{$(3)$} & \multicolumn{1}{c}{$(4)$} \\
\hline Constant & $9.907^{* * *}$ & $9.811^{* * *}$ & $9.808^{* * *}$ & $9.810^{* * *}$ \\
& {$[0.046]$} & {$[0.048]$} & {$[0.048]$} & {$[0.048]$} \\
Observations & 17,835 & 17,835 & 17,835 & 17,835 \\
$\mathrm{R}^{2}$ & 0.91 & 0.91 & 0.91 & 0.91 \\
Adj. $\mathrm{R}^{2}$ & 0.90 & 0.90 & 0.90 & 0.90 \\
\hline
\end{tabular}

Notes: This table shows the results from a regression model using the logarithm of the transaction price per square meter as dependent variable. Robust standard errors clustered at the postcode-year level in brackets. Significance at the 0.10, 0.05, and 0.01 level is indicated by ${ }^{*}, * *$, and ${ }^{* * *}$, respectively.

aDefault for number of stories is "Four stories"

bDefault for dwelling type is "Semi-detached"

${ }^{\mathrm{c}}$ Rated 5 to 7 on a scale of 1 to 9

${ }^{\mathrm{d}}$ Rated 8 or 9 on a scale of 1 to 9

e 2 or 3 types of insulation out of 5

${ }^{\mathrm{f}} 4$ or 5 types of insulation out of 5

gDefault is a gas or coal heater in place

hDefault for construction period is "Pre 1930"

The fourth column analyzes the value of an EPC label for each label category separately. An affordable dwelling with a low primary energy demand, having an A label, sells for 5.6 percent more compared to an otherwise similar non-labeled affordable dwelling. This implies that an average dwelling with a low primary energy demand sells for approximately EUR 9,300 more than a non-labeled dwelling. Transaction premiums for homes with an EPC label of B amount to 1.1 percent. On average, this implies a premium of some EUR 1,800 as compared to similar non-labeled dwellings. On the other hand, homes with a high primary energy demand, those with EPC labels in categories C to G, sell at a discount in the order of 1.5 percent compared to homes without a label. For example, an F labeled dwelling on average sells for EUR 2,600 less than a comparable non-labeled dwelling.

\subsubsection{Heterogeneous Effects}

Having established the baseline results in the previous analysis, we now turn to the EPC labeled set of homes in our sample to further disentangle the observed capitalization of energy labels. The analyses presented in this section employ the same specifications as presented in Table 6.2, and the results for the control variables are as before, so we omit these from Table 6.3. However, we do show results for thermal and maintenance quality.

The first column of the table displays the performance of buildings with a low primary energy demand, A and B labeled buildings, relative to buildings with a high primary energy demand, buildings with an EPC label of $\mathrm{C}$ or lower. These dwellings command a premium of 2.6 percent compared to dwellings with a high primary energy demand. This corresponds to an increase of about EUR 3,900 euros in transaction value. Although the categorization employed here is slightly different from the one used by Brounen and Kok (2011), the observed premium is in line with the 3.7 percent increase they document. 
Table 6.3: Transaction Value and Label Quality within the EPC Labeled Sample

\begin{tabular}{|c|c|c|c|}
\hline \multirow{2}{*}{ Energy label A or B (1=yes) } & (1) & (2) & (3) \\
\hline & $\begin{array}{l}0.026^{* * *} \\
{[0.007]}\end{array}$ & & \\
\hline Energy performance index & & $\begin{array}{c}-0.086^{* * *} \\
{[0.020]}\end{array}$ & \\
\hline Energy performance index ${ }^{2}$ & & $\begin{array}{l}0.016^{* * *} \\
{[0.004]}\end{array}$ & \\
\hline \multicolumn{4}{|c|}{ Energy performance certificate (1=yes) } \\
\hline Label A & & & $\begin{array}{l}0.063^{* * *} \\
{[0.019]}\end{array}$ \\
\hline Label B & & & $\begin{array}{l}0.020^{* * *} \\
{[0.007]}\end{array}$ \\
\hline \multicolumn{4}{|l|}{ Label C } \\
\hline Label D & & & $\begin{array}{r}-0.007^{*} \\
{[0.003]}\end{array}$ \\
\hline Label E & & & $\begin{array}{c}-0.016^{* * *} \\
{[0.005]}\end{array}$ \\
\hline Label F & & & $\begin{array}{l}-0.017^{* *} \\
{[0.007]}\end{array}$ \\
\hline Label G & & & $\begin{array}{r}-0.013^{*} \\
{[0.008]}\end{array}$ \\
\hline \multicolumn{3}{|l|}{ Thermal and quality characteristics } & $0.039 * * *$ \\
\hline Interior maintenance medium ${ }^{a}$ & {$[0.007]$} & {$[0.007]$} & {$[0.007]$} \\
\hline Interior maintenance high ${ }^{\mathrm{b}}$ & $\begin{array}{l}0.110^{* * *} \\
{[0.017]}\end{array}$ & $\begin{array}{l}0.109 * * * \\
{[0.016]}\end{array}$ & $\begin{array}{l}0.108^{* * *} \\
{[0.016]}\end{array}$ \\
\hline Exterior maintenance medium ${ }^{\mathrm{a}}$ & $\begin{array}{c}0.024 \\
{[0.018]}\end{array}$ & $\begin{array}{c}0.023 \\
{[0.018]}\end{array}$ & $\begin{array}{c}0.023 \\
{[0.018]}\end{array}$ \\
\hline Exterior maintenance high ${ }^{\mathrm{b}}$ & $\begin{array}{c}0.032 \\
{[0.021]}\end{array}$ & $\begin{array}{c}0.031 \\
{[0.021]}\end{array}$ & $\begin{array}{c}0.030 \\
{[0.021]}\end{array}$ \\
\hline Insulation quality medium $^{c}$ & $\begin{array}{c}0.004 \\
{[0.004]}\end{array}$ & $\begin{array}{c}0.003 \\
{[0.004]}\end{array}$ & $\begin{array}{c}0.003 \\
{[0.004]}\end{array}$ \\
\hline Insulation quality high ${ }^{\mathrm{d}}$ & $\begin{array}{l}0.017^{* * *} \\
{[0.005]}\end{array}$ & $\begin{array}{l}0.016^{* * *} \\
{[0.005]}\end{array}$ & $\begin{array}{l}0.015^{* * *} \\
{[0.005]}\end{array}$ \\
\hline Heating information missing ${ }^{\mathrm{e}}$ & $\begin{array}{l}0.025^{* * *} \\
{[0.009]}\end{array}$ & $\begin{array}{l}0.024^{* *} \\
{[0.010]}\end{array}$ & $\begin{array}{l}0.025^{* * *} \\
{[0.010]}\end{array}$ \\
\hline Central heating ${ }^{\mathrm{e}}$ & $\begin{array}{l}0.049^{* * *} \\
{[0.009]}\end{array}$ & $\begin{array}{l}0.045^{* * *} \\
{[0.009]}\end{array}$ & $\begin{array}{l}0.047^{* * *} \\
{[0.009]}\end{array}$ \\
\hline Building characteristics & yes & yes & yes \\
\hline Transaction characteristics & yes & yes & yes \\
\hline Location fixed effects & yes & yes & yes \\
\hline Time fixed effects (year-quarter) & yes & yes & yes \\
\hline
\end{tabular}


Table 6.3 (continued from previous page)

\begin{tabular}{lccc}
\hline & $(1)$ & $(2)$ & $(3)$ \\
\hline Constant & $9.865^{* * *}$ & $9.984^{* * *}$ & $9.880^{* * *}$ \\
& {$[0.059]$} & {$[0.064]$} & {$[0.060]$} \\
Observations & 11,411 & 11,411 & 11,411 \\
$\mathrm{R}^{2}$ & 0.91 & 0.91 & 0.91 \\
Adj. $\mathrm{R}^{2}$ & 0.90 & 0.90 & 0.90 \\
\hline
\end{tabular}

Notes: This table shows the results from a regression model using the logarithm of the transaction price per square foot as dependent variable. Robust standard errors clustered at the postcode-year level in brackets. Significance at the $0.10,0.05$, and 0.01 level is indicated by ${ }^{*}, * *$, and ${ }^{* * *}$, respectively.

${ }^{\text {a Rated }} 5$ to 7 on a scale of 1 to 9

${ }^{b}$ Rated 8 or 9 on a scale of 1 to 9

c 2 or 3 types of insulation out of 5

$\mathrm{d} 4$ or 5 types of insulation out of 5

${ }^{e}$ Default is a gas or coal heater in place

The actual categorization of the energy labels is based on the energy performance index. This index is constituted of a rating that directly relates to the thermal quality of the home and takes the insulation quality, heating installation, (natural) ventilation and indoor air climate, solar systems and built-in-lighting into account. The lowest rating indicates the most energy efficient home. The second column of Table 6.3 analyzes the direct impact of the level of a home's energy performance index on the transaction value per square meter. We document a non-linear relationship between the energy performance index and transaction values of the dwellings in our sample.

Figure 6.2 displays the implicit function of the energy performance index based on the coefficients for the energy performance index in the second column of Table 6.3. The figure shows a clear non-linear relationship between the energy performance index and the value increment associated with energy efficiency. The value increment is highest for dwellings with a low primary energy demand and decreases quickly for dwellings with a higher primary energy demand.

The paucity of $\mathrm{A}++$ and $\mathrm{A}+$ labeled dwellings in our sample prevents us from observing their economic performance directly, but the graph in Figure 6.2 allows us to predict it. The implied premium for a dwelling with an A++ label relative to an otherwise comparable home with a $\mathrm{G}$ label is 11.7 percent. Interestingly, the graph suggests that a major part of that premium can be realized when an A-labeled dwelling is further upgraded to A++: 5.2 percent, which corresponds to an increase in transaction value of approximately EUR 9,300. Dwellings with an A label command a 6.5 percent higher transaction price than comparable dwellings with a G label. On average, this implies an increase in transaction value of some EUR 9,600. The difference in the value increment between homes with an $\mathrm{E}$ label or lower relative to one with a $\mathrm{G}$ label is negligible.

The third column of Table 6.3 further differentiates across EPC label categories to assess the value of high energy efficiency in affordable housing using the most elaborate set of building and quality controls. With respect to the impact of energy efficiency we investigate the impact of the different EPC labels relative to a dwelling with an EPC label of level C. Dwellings with 
Figure 6.2: Transaction Value and Energy Performance Index

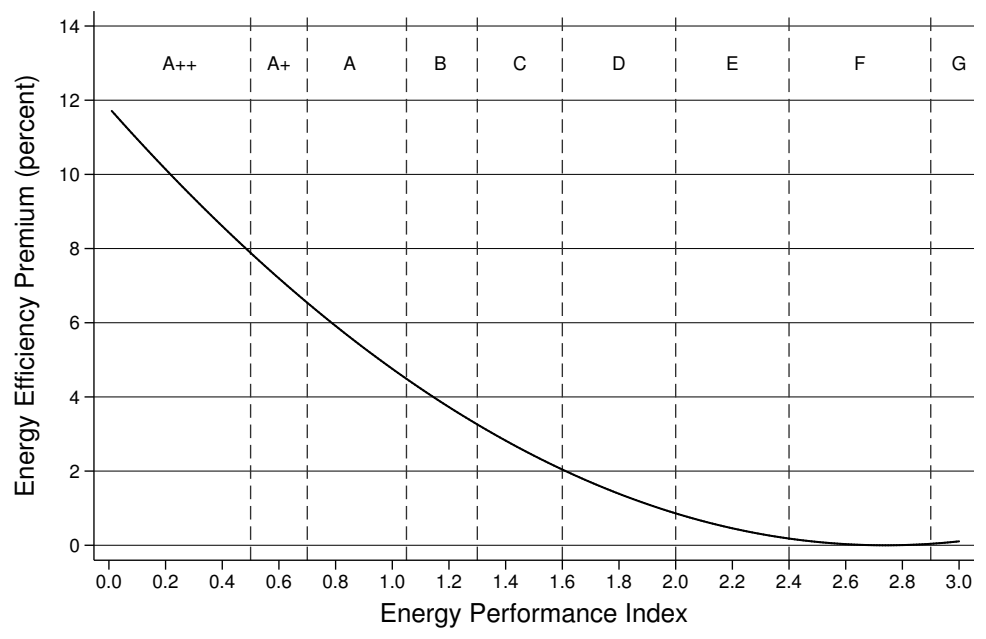

Notes: The above figure displays the non-linear relationship between the energy performance index and the incremental transaction value per square meter. The graph has been rebased to zero for ease of interpretation. The vertical dashed lines display the different cut-off values for the energy labels. This categorization has been revised in January 2015; the cut-off values used are the ones applicable at the time of transaction.

the lowest primary energy demand, those having an A label, sell for 6.3 percent more compared to those with a C label, which translates into an increase in transaction value of about EUR 9,700. A dwelling with an EPC label of B sells for 2 percent more compared to a similar home with a $\mathrm{C}$ label. Homes with labels between D and G sell at small discounts, varying between 1 and 2 percent.

However, these value effects do not paint a complete picture for affordable housing providers who want to improve the sustainability of their housing stock. When existing homes are newly refurbished, increased energy efficiency is just one of the outcomes. Refurbishment will also lead to better interior and exterior maintenance, and the improved label quality will likely be partly driven by investments in better insulation. These latter effects are priced on top of the label effect, and the combined value effect is substantially larger than that of the improved label quality alone. Table 6.3 underscores this.

Let us take the example of an affordable housing institution that refurbishes dwellings initially labeled E, F, or G, and succeeds in improving their energy efficiency to label A. In the process, it improves both the interior maintenance and the insulation quality level from low to high. In that case, the results in Table 6.3 predict a total increase in value of 20.5 percent: 7.8 percent for the jump in label quality, 11.0 percent for the increased interior maintenance, and 1.7 percent for the improved insulation. If we apply that combined value increase to the average square meter value of E, F and G labeled dwellings reported in Table 6.1, we get a predicted value for an A-labeled building of almost EUR 2,000, which is close to the actual average value reported in Table 6.1. This combined result indicates that green redevelopment of affordable housing is best conducted as part of a broader renovation. 


\subsection{Conclusions and Policy Implications}

The Dutch housing sector spent approximately 11.3 billion euros on energy in 2010, emitting approximately 29,500 tons of $\mathrm{CO}_{2}$. For society to apportion less disposable income to household energy expenses in the present and the future, regulators are pushing building owners to abate energy costs through retrofit investments and more stringent and energy-efficient building codes. For the Netherlands, as for other European countries, an important sector in decreasing household energy consumption is the affordable housing sector.

One of the key differences between the owner-occupied residential market and the affordable housing rental market is that affordable housing institutions cannot directly benefit from investments in energy efficiency through lower energy expenses. The tenant pays the reduced energy bill and the building owner undertakes the energy efficiency investment, resulting in a split incentive. Recouping that lower energy bill through higher rents is difficult due to an extensive program of rent protection.

One solution for affordable housing owners would be to sell energy efficient affordable dwellings in the housing market. In principle, this solution is open to affordable housing institutions everywhere, but in many countries, there are legal impediments to doing so. Dutch affordable housing institutions are allowed to sell from their stock, and we use this unique setting in housing policy for our analysis of the value of energy efficiency in affordable housing.

We employ a hedonic pricing model to analyze the impact of energy efficiency on the transaction price per square meter and we separate the sample into EPC labeled and non-labeled dwellings. The results of our EPC labeled sample show that the most energy efficient homes, homes with an energy label of A or B, command a higher transaction price per square meter. We document that a dwelling with an A label commands a 6.3 percent premium compared to an otherwise similar dwelling with a C label, and this premium is 2.0 percent for homes having a B label. This suggests that the average $C$ labeled home in our sample would sell for some EUR 9,700 more were it to trade as an A label. The increase in transaction value for a B label is just over EUR 3,000.

To get a sense of the economic importance of these average transaction premiums we compare them to estimates regarding the costs that affordable housing institutions face when making sustainability retrofits. For example, estimates carried out for the demonstration sites of the Building Energy Efficiency for Massive Market Uptake project as part of the European Union's $7^{\text {th }}$ framework program provide some anecdotal evidence on the costs of energy efficiency retrofitting in the construction market (Chegut and Holtermans, 2014). The estimated costs of energy efficient retrofits for the demonstration sites are approximately EUR 190 per square meter for a typical site. The results documented in Table 6.3 indicate that renovating a E-G labeled dwelling to achieve an A label would increase the transaction price per square meter by EUR 129 . However, this cost-benefit comparison only involves the pure value effect of the label increase, but the results depicted in Table 6.3 show that the combined value effects of refurbishments of affordable homes are substantially larger. We find combined premiums of just over 20 percent, which is equivalent to an increase in price per square meter of EUR 330, which would more than pay for the retrofit.

These rough estimates suggest that the investment in energy efficient retrofits may be partly or fully compensated by an increase in transaction price. However, it is not clear whether the 
retrofit costs from the demonstration cites are representative for the Dutch affordable housing situation, so we cannot draw firm conclusions on this matter. More research on the costs of a larger sample of energy efficiency retrofits should be conducted in order to draw grounded conclusions regarding the cost-benefit trade-off of such retrofits in affordable housing.

Still, given the economic and statistical significance of the results documented in this study, we find that the affordable housing market values energy efficiency and is willing to pay for it. The Dutch affordable housing sector offers a policy example of how to potentially amortize energy efficiency investments through transaction premiums for energy efficient dwellings. Other countries with affordable housing institutions and split incentive issues may consider the Dutch model as one approach to resolve this disincentive for energy efficiency investments in the affordable housing market. This could foster the proliferation of energy efficiency in the housing market. 



\section{Chapter 7}

\section{Conclusion}

This dissertation explores two subjects in the field of real estate finance. The first topic addresses asymmetric information in the commercial real estate market. It investigates how the distance of owners to their asset and how real estate advisors impact the financial performance of office buildings. The second topic assesses the financial implications of the energy and environmental performance of buildings in the U.S. commercial real estate market and the Dutch affordable housing sector.

The first chapter of my dissertation investigates the economic effects of owner distance in the commercial real estate market. Whereas the importance of investor proximity has been extensively investigated in the finance literature, no such study has been performed for real estate. Coval and Moskowitz (2001), for example, show that mutual fund managers exhibit a preference for locally headquartered firms and that these managers earn an abnormal return by doing so. First, I observe a clear pattern in owner distance: far-away owners tend to invest in higher quality assets, possibly to alleviate concerns about informational asymmetries. Second, owner distance is met with a significant discount in the effective rental level of an asset, especially so in case of lower quality assets. In addition, measuring owner distance as straight-line distance shows that this effect is non-linear. The effective rental premium decreases the fastest over short distances, while owner distance does not seem to matter anymore once the owner is far away from the asset. Third, I document that retaining a local property manager, with the market knowledge and expertise to manage the asset, mitigates the distance discount far-away owners face.

Related to the finding in the first chapter that property managers are able to partly mitigate the rent discount borne by the owner being far away from her asset, the second chapter of my dissertation focuses on the added value of real estate advisors in the commercial real estate market. More specifically, this chapter examines how the size and reputation of real estate advisors is related to the financial outcomes of rental and sales transactions. Real estate advisors are heavily employed in the real estate market to rent, buy, manage, and sell assets. In 2015 alone the total value of commercial property transactions in the U.S. office market was USD 72 billion (CoStar Group, Inc., 2016).

Prior research on the impact of real estate brokerage has focused primarily on the residential real estate market. A well-known study by Levitt and Syverson (2008) documents that real estate agents keep their own homes longer at the market and sell them at a premium, suggesting that they use their superior market knowledge and expertise to their own advantage. I investigate 
the impact of real estate advisors, in a variety of capacities, on the rent and transaction value of office buildings in the U.S. Whereas the largest leasing agents and property managers are able to achieve higher rental levels (no effect on occupancy rate), the largest listing and buying brokers underperform relative to their smaller competitors. This raises the question why these real estate advisors have such a large market share. In line with the mergers and acquisition literature I document that the largest commercial real estate advisors are involved in the most complex deals and although these large transaction advisors do not seem to achieve better deals for their clients in terms of pricing, they are able to buy and sell assets more quickly.

The second main topic of my dissertation examines the implications of energy and environmental building performance on the financial performance of buildings. Chapter three contributes to our understanding of the economic implications of environmental building certification in the U.S. office market. The effects of certification and quality disclosure in different industries have been documented quite extensively. In general, certification and disclosure programs provide information to the market that is otherwise hard to obtain. For example for the restaurant industry, Jin and Leslie (2003) investigate the impact of the introduction of restaurant hygiene quality grade cards in Los Angeles. The authors document that since the introduction of the legislation the hygiene score of restaurants has increased substantially and consumers are sensitive to changes in hygiene quality.

The adoption of environmental building certification programs in the U.S. office market has increased rapidly over the last decade, and the market share of certified office space has increased from less than 6 percent at the end of 2005 to almost 40 percent at the end of 2014 . Previous studies that examined the implications of environmental building certification programs assessed these buildings at a single point in time comparing certified buildings to similar non-certified buildings. These studies have been criticized for the lack of comparability of certified and non-certified buildings, since the observable building characteristics, and likely also the unobservable characteristics, of these buildings differ quite dramatically across certified and non-certified buildings. By tracking the rental growth for a set of certified and non-certified office buildings over time I construct a constant quality measure of financial performance. The results of these repeated rent indices show that there is no significant difference in rental growth between environmentally certified and non-certified buildings.

Nevertheless, despite the absence of a difference in rental growth this does not preclude the possibility that the rental levels and transaction prices of environmentally certified buildings are significantly different from those of non-certified buildings. In line with this hypothesis, and corroborating previous research, the performance attribution analysis shows that environmentally certified office buildings command higher rents and transaction price as compared to otherwise similar office buildings. Moreover, I document significant heterogeneity in the determinants of this so-called "green" premium. Local climate conditions, electricity prices and certification levels and scores affect the premium significantly.

Whereas there is growing academic evidence for the presence of a rent, occupancy, and transaction price premium for environmentally certified buildings, little is known about the implications this may have on the financing costs of these assets. When the inherent risk in these investments is lower due to a more stable occupancy rate, higher rents and sale prices, and higher liquidity this should also impact the financing costs. In addition, while the "green" premium is an incentive to invest in these assets, a decrease in the financing costs of these assets 
may be another incentive to invest in environmentally certified assets.

Chapter five of this dissertation analyzes the cost of capital for environmentally certified buildings. I analyze the spreads on commercial mortgages collateralized by environmentally certified assets and the spreads on corporate debt for U.S. REITs, both at issuance and while trading in the secondary market. The results show that the spread on commercial mortgages collateralized by environmentally certified assets is significantly lower relative to the spreads on mortgages for similar non-certified buildings. In addition, an increasing share of environmentally certified assets in a REITs' portfolio also lowers the spreads on corporate bonds. This holds for the time at which the bond is issued as well as while the bond is traded in the secondary market.

Housing represents the largest share of the total real estate market, and in the housing market a large part of the building stock consists of affordable housing, especially so in the Netherlands. In relative terms, the affordable housing sector in the Netherlands is the largest in Europe: almost one third of the housing market consists of affordable housing. Importantly, only some four hundred institutions own this substantial part of the housing stock. Hence, incentivizing these owners to improve the energy and environmental performance of their dwellings has the potential to make a large difference in the energy and environmental performance of the total Dutch housing stock.

However, affordable housing institutions, given their societal function, are severely restricted in adjusting the rental rate of their dwellings to reflect investments in energy efficiency. Since the affordable housing institutions in the Netherlands are allowed to sell part of their stock in the private market, one way for these institutions to recoup part of their investment is at the time of sale. Chapter five of this dissertation investigates the financial implications of energy efficiency in the affordable housing sector in the Netherlands, by analyzing homes sold by affordable housing institutions. I document that homes with high energy efficiency sell for a 2.0-6.3 percent premium as compared to otherwise similar homes. Combining the premium for high energy efficiency with the transaction increments related to the overall quality of a dwelling, shows that when part of a larger renovation package these investments can be cost-effective. 



\section{Chapter 8}

\section{Research Impact}

Real estate is the largest asset class in the U.S. capital market - representing USD 30 trillion, or some 41 percent of investible capital. Of this share, housing makes up about two-thirds and commercial real estate one-third (Geltner et al., 2014). The sheer size of the asset class alone validates it as a subject for academic investigation, especially when considering how the absence of reliable and detailed information has hampered research in this field.

The studies presented in this dissertation contribute to our understanding of the financial performance of real estate and the inner workings of the real estate market in a number of ways. The two research streams laid out each offer a distinct contribution for different stakeholders. Chapters two and three focus on information asymmetry and the functioning of the real estate market, whereas chapters four to six examine the financial implications of the environmental performance of the built environment.

Owner proximity or distance and its effect on the rental performance of commercial real estate is of interest in chapter two. First, there is a clear pattern in owner proximity: distant owners tend to invest in higher quality assets. Second, being far away from one's asset has a significant negative impact on the cash flow, as measured by the effective rent level of the asset. Third, employing a local property manager to manage the asset can partly offset this distance discount. These findings have important implications for real estate investors. Diversification has long been regarded as the only free-lunch in investment. The documented negative consequences of being far away from an asset suggest that investors face a trade-off between the benefits of diversification and a lower return on the investment. Moreover, this study provides some evidence that real estate investors can mitigate the negative distance effect by hiring a local property manager.

Chapter three assesses the added value of real estate transaction advisors in the commercial real estate market. Real estate transaction advisors are employed in all major deals in commercial real estate, both in ownership transactions (acquiring or selling an asset) and rental transactions (leasing an asset). Most prominent real estate investors only employ the largest real estate service firms to assist in their asset transactions. The aim of this study is to investigate whether these advisors also add the most value for their clients, or the relationship between advisor transaction activity and deal performance. With respect to the rental transactions the findings correspond to what one might expect: the most active advisors are able to obtain higher rents for their clients. Interestingly, the opposite relationship occurs in ownership transactions. The most active real estate transaction advisors pay more when assisting the buying party in a transaction and 
accept a lower offer when they represent the selling party in a transaction, relative to boutique advisors. Nevertheless, part of these counterintuitive price effects can be explained by deal complexity - larger real estate transaction advisors are more often involved in more complex deals. In addition, large real estate advisors do provide higher liquidity - the largest real estate transaction advisors are able to acquire or dispose of an asset more quickly. Therefore, in terms of rental transactions real estate investors are best served by the most active real estate transaction advisors. However, when it comes to ownership transactions, real estate investors face a trade-off between price and liquidity when hiring a real estate transaction advisor to acquire or dispose of an office building.

Chapters four and five focus on the financial implications of the environmental performance of commercial real estate in the U.S. Chapter six examines whether refurbishing affordable housing to a higher energy efficiency standard is financially viable in a severely financially constrained sector. By now, it is common knowledge that buildings are responsible for a large share of the consumption of natural resources and pollution. Therefore, the built environment is instrumental in achieving climate goals as set out in international accords - such as the COP21 2015 in Paris. Moreover, an increase in the financial performance of buildings would provide a strong incentive for the real estate industry to improve the environmental performance of buildings.

The environmental performance of buildings and its impact on the rent level, occupancy rate, and transaction price of commercial real estate has been subject of debate in both the industry and academia. The uptake of voluntary environmental certification programs in the U.S. commercial real estate market has grown rapidly over the last decade. In the 30 largest office markets in the U.S., the share of environmentally certified buildings, in terms of square footage, has grown from 5.7 percent at the end of 2005 to almost 40 percent at the end of 2014. Early studies in the field document positive rent, occupancy and price effects for environmentally certified office buildings. Research has shown that certified buildings tend to be newer, larger and of higher quality. One major criticism to these studies, therefore, has been the lack of comparability between environmentally certified and non-certified buildings. To alleviate this concern, the rental growth of environmentally certified and non-certified buildings is tracked over ten years. The resulting rent indices show that certified office buildings, on average, do not outperform non-certified office buildings in terms of rental growth. The results from a performance attribution analysis show that the capitalization of environmental certification in the commercial real estate market varies with local climate conditions, local energy prices, and certification levels and scores. On aggregate, these results provide evidence that the market prices the environmental characteristics of commercial real estate.

Whereas rental, occupancy and price premiums for environmentally certified real estate provide an incentive to the investment community to invest in more energy efficient and sustainable assets, lower financing costs for such assets may provide another impetus. Environmentally certified buildings are associated with higher and more stable occupancy rates, which should reflect positively on the riskiness of the asset. The lower risk of the asset may subsequently be related to better financing terms. Chapter five of this dissertation investigates this question. By combining information regarding the environmental certification of a building with the mortgage collateralizing the asset and the debt used at the corporate level for U.S. REITs, differences in the spread for these two types of debt are examined. Since the financing of the 
asset is directly tied to the asset, the real estate sector provides a unique setting to investigate the effect of energy efficiency and sustainability on the cost of debt. Results indicate that the market prices in the environmental performance of an asset in the form of lower spreads for environmentally certified buildings. This finding holds for both mortgages collateralizing an asset as well as bonds used at the corporate level. Moreover, the spread on corporate level bonds decreases with an increasing share of environmentally certified buildings in the portfolio of U.S. REITs when bonds are traded on the secondary market.

As suggested by the statistics at the beginning of this chapter, housing encompasses the largest share of the real estate market. Within the housing market, affordable housing represents a significant share as well. Traditionally, affordable housing represents some 17 percent of the housing stock in Europe. The share of affordable housing in the Dutch housing market is even larger - approximately 31 percent. The rental market in general suffers from a split-incentive problem regarding the improvement of the energy efficiency of dwellings: the owner makes the investment to improve the energy efficiency and the tenant benefits from a lower utility bill. This problem is even more severe for affordable housing institutions that are legally constrained in increasing the rents for their dwellings. Affordable housing institutions in the Netherlands are allowed to sell part of their housing stock to individuals in the private market. Despite these institutions not being able to benefit from investing in the energy efficiency of their dwellings through higher rents, they may be able to benefit from their investment at the time of sale. The question whether the market recognizes the energy efficiency of dwellings in affordable housing in the Netherlands is the focal point of chapter six. The results indicate that high energy efficient dwellings sell for 2.0 to 6.3 percent more, relative to otherwise similar dwellings with low energy efficiency. However, these premiums only involve the pure value effect of a label increase. The combined value effects of refurbishments of affordable homes are substantially larger. The combined premiums for refurbishing a dwelling — including improving the energy efficiency - are just over 20 percent, which would more than pay for the retrofit.

Taken together, the studies presented in this dissertation provide answers to a variety of questions in the real estate market that can be applied by different stakeholders. The findings in chapter two and three are of special interest to investors in commercial real estate and provide interesting insights in the trade-off these investors face when choosing where and how to invest in real estate. The focus of chapters four to six is on the relationship between the environmental and financial performance of buildings. The findings in these chapters are of direct interest to policy makers, investors and occupants of real assets. 



\title{
References
}

\author{
AEdes (2013a): "Expert: Hoe Ziet de Gemiddelde Corporatiewoning \\ Eruit?" Retrieved January 28, 2014 from: http://www.aedes.nl/content/ \\ feiten-en-cijfers/woning/hoe-ziet-de-gemiddelde-corporatiewoning-eruit/ \\ Expert--Hoe-ziet-de-gemiddelde-corporatiewoning-er.xml.
}
- (2013b): "Expert: Wie Wonen Er in een Corporatiewon- ing?" Retrieved January 28, 2014 from: http://www.aedes.nl/content/ feiten-en-cijfers/bewoners/wie-zijn-de-bewoners-van-een-corporatiewoning/ Expert--Wie-zijn-de-bewoners-van-een-corporatiewon.xml.

Agarwal, S. And R. Hauswald (2010): “Distance and Private Information in Lending," Review of Financial Studies, 23, 2757-2788.

Ahearne, A. G., W. L. Griever, And F. E. WArnock (2004): “Information Costs and Home Bias: An Analysis of US Holdings of Foreign Equities," Journal of International Economics, 62, 313-336.

Albuquerque, R. A., A. Durnev, And Y. Koskinen (2014): “Corporate Social Responsibility and Firm Risk: Theory and Empirical Evidence," Working paper.

Ambrose, B. W., N. E. Coulson, And J. Yoshida (2015): “The Repeat Rent Index," Review of Economics and Statistics, 97, 939-950.

Ambrose, B. W., S. R. Ehrlich, W. T. Hughes, And S. M. WAchter (2000): “REIT Economies of Scale: Fact or Fiction?" The Journal of Real Estate Finance and Economics, 20, 211-224.

Ambrose, B. W., M. J. Highfield, And P. D. Linneman (2005): “Real Estate and Economies of Scale: The Case of REITs," Real Estate Economics, 33, 323-350.

AN, X. AND G. Pivo (2015): “Default Risk of Securitized Commercial Mortgages: Do Sustainability Property Features Matter?" Working paper.

Anderson, R. C., S. A. MAnsi, And D. M. Reeb (2003): “Founding Family Ownership and the Agency Cost of Debt," Journal of Financial Economics, 68, 263-285.

Attig, N., S. E. Ghoul, O. Guedhami, And J. Suh (2013): “Corporate Social Responsibility and Credit Ratings," Journal of Business Ethics, 117, 679-694. 
Autoriteit WoningCorporaties (2012): “De Corporatiesector in Cijfers,” Retrieved February 10, 2014 from: http://www.cfv.nl/financieel_toezicht/de_corporatiesector_in_ cijfers.

(2013): Jaarverslag 2012: Toezicht Door Financiële Risicoanalyses en Interventie: Centraal Fonds Volkshuisvesting, Autoriteit Woningcorporaties.

AYdin, E., D. BROUnEN, AND N. KOK (2015): “Capitalization of Energy Efficiency in the Housing Market," Working paper.

BAUER, R. AND D. HANN (2010): “Corporate Environmental Management and Credit Risk," Working paper.

Bernheim, B. D. And J. Meer (2013): “Do Real Estate Brokers Add Value When Listing Services Are Unbundled?” Economic Inquiry, 51, 1166-1182.

Bernstein, S., X. GiROUd, AND R. R. TOWnSEnd (2015): “The Impact of Venture Capital Monitoring," The Journal of Finance, Advance publication.

BERS, M. AND T. SPRINGER (1997): “Economies-of-Scale for Real Estate Investment Trusts," Journal of Real Estate Research, 14, 275-290.

Bertoldi, P., B. HiRL, AND N. LABANCA (2012): Energy Efficiency Report Status Update 2012; Electricity Consumption and Efficiency Trends in the EU-27, European Union.

Binnenlandse Zaken en KoninkrijKsRelaties (1992): "Besluit Beheer SocialeHuursector," Retrieved February 7, 2014 from: http://wetten. overheid.nl/BWBR0005686/ geldigheidsdatum_07-02-2014.

BODNARUK, A. (2009): "Proximity Always Matters: Local Bias When the Set of Local Companies Changes," Review of Finance, 13, 629-656.

Bollinger, B., P. Leslie, AND A. Sorensen (2011): “Calorie Posting in Chain Restaurants," American Economic Journal: Economic Policy, 3, 91-128.

Bonde, M. AND H. S. Song (2014): “Does Greater Energy Performance Have an Impact on Real Estate Revenues?" Journal of Sustainable Real Estate, 5, 171-182.

Bowers, H. M. AND R. E. Miller (1990): “Choice of Investment Banker and Shareholders' Wealth of Firms Involved in Acquisitions," Financial Management, 34-44.

BronnenberG, B. J., S. K. Dhar, And J.-P. H. DubÉ (2009): “Brand History, Geography, and the Persistence of Brand Shares," Journal of political Economy, 117, 87-115.

Brounen, D. AND P. M. A. EichHoltz (2005): “Corporate Real Estate Ownership Implications: International Performance Evidence," The Journal of Real Estate Finance and Economics, 30, 429445.

BROUNEN, D. AND N. KOK (2011): “On the Economics of Energy Labels in the Housing Market," Journal of Environmental Economics and Management, 62, 166-179. 
CapozzA, D. R. And P. J. Seguin (1998): “Managerial Style and Firm Value," Real Estate Economics, 26, 131-150.

CARBOn TRUST (2013): “Conversion Factors; Energy and Carbon Conversions 2013 Update," Retrieved from: http://www.carbontrust.com/media/18223/ctl153_conversion_factors . pdf.

Cerin, P., L. G. Hassel, And N. Semenova (2014): “Energy Performance and Housing Prices," Sustainable Development, 22, 404-419.

CHAVA, S. (2014): “Environmental Externalities and Cost of Capital," Management Science, 60, 2223-2247.

Chegut, A., P. M. A. Eichholtz, And N. KOK (2014): “Supply, Demand and the Value of Green Buildings," Urban Studies, 51, 22-43.

Chegut, A. And R. Holtermans (2014): “Determination of the Economic Outcomes of Energy Efficiency Retrofits," Report, European Union-Building Energy Efficiency for Massive market UPtake, Building Energy Efficiency for Massive market UPtake.

Copiello, S. (2015): “Achieving Affordable Housing Through Energy Efficiency Strategy," Energy Policy, 85, 288-298.

CoStar Group, Inc. (2016): “The CoStar Office Report, Year-End 2015: National Office Market,” Retrieved from: http://www.costar.com.

CoStar Realty Information, InC. (2011): “CoStar Property,” Retrieved from: http: //www . costar.com.

_ (2013): “CoStar Property/Comps," Retrieved from: http://www . costar. com.

— (2015): “CoStar Property/Comps," Retrieved from: http://www . costar. com.

Coval, J. D. And T. J. Moskowitz (1999): “Home Bias at Home: Local Equity Preference in Domestic Portfolios," The Journal of Finance, 54, 2045-2073.

(2001): “The Geography of Investment: Informed Trading and Asset Prices," Journal of Political Economy, 109, 811-841.

DAHL, M. S. AND O. SORENSON (2012): “Home Sweet Home: Entrepreneurs' Location Choices and the Performance of Their Ventures," Management Science, 58, 1059-1071.

D'Antonio, L., T. Johnsen, And R. B. Hutton (1997): “Expanding Socially Screened Portfolios: An Attribution Analysis of Bond Performance," Journal of Investing, 6, 79-86.

DAstrup, S. R., J. G. Zivin, D. L. COSTA, AND M. E. KAHN (2012): “Understanding the Solar Home Price Premium: Electricity Generation and "Green" Social Status," European Economic Review, 56, 961-973.

Degryse, H. And S. Ongena (2005): “Distance, Lending Relationships, and Competition," The Journal of Finance, 60, 231-266. 
DENG, Y., Z. LI, AND J. M. QUIGLEY (2012): “Economic Returns to Energy-Efficient Investments in the Housing Market: Evidence from Singapore," Regional Science and Urban Economics, 42, 506-515.

DinAN, T. M. AND J. A. MirAnOWSKI (1989): “Estimating the Implicit Price of Energy Efficiency Improvements in the Residential Housing Market: A Hedonic Approach," Journal of Urban Economics, 25, 52-67.

Dranove, D. AND G. Z. Jin (2010): "Quality Disclosure and Certification: Theory and Practice," Journal of Economic Literature, 48, 935-963.

ECCles, R. G., I. IOANNOU, AND G. SERAFEIM (2014): “The Impact of Corporate Sustainability on Organizational Processes and Performance," Management Science, 60, 2835-2857.

EIA (2013): “International Energy Outlook 2013," Report, U.S. Energy Information Agency, retrieved from: http://www.eia.gov/forecasts/archive/ieo13/pdf/0484(2013).pdf.

EichHoltz, P. M. A., N. Gugler, AND N. KOK (2011): “Transparancy, Integration, and the Cost of International Real Estate Investment," Journal of Real Estate Finance and Economics, 43, 152-173.

Eichholtz, P. M. A., K. KoediJK, AND M. Schweitzer (2001): “Global Property Investment and the Costs of International Diversification," Journal of International Money and Finance, 20, 349-366.

EichHoltZ, P. M. A., N. KoK, AND J. M. Quigley (2010): “Doing Well by Doing Good? Green Office Buildings," American Economic Review, 100, 2492-2509.

- (2013): "The Economics of Green Building," Review of Economics and Statistics, 95, 50-63.

EichHoltZ, P. M. A., N. KoK, AND E. YÖndeR (2012a): “Portfolio Greenness and the Financial Performance of REITs," Journal of International Money and Finance, 31, 1911-1929.

Eichholtz, P. M. A., S. Straetmans, And M. Theebe (2012b): “The Amsterdam Rent Index: The Housing Market and the Economy, 1550-1850," Journal of Housing Economics, 21, 269-282.

ENKVist, P.-A., T. NAuCler, AND J. Rosander (2007): “A Cost Curve for Greenhouse Gas Reduction," The McKinsey Quarterley, 1, 35-45.

EPA (2016): “Draft Inventory of U.S. Greenhouse Gas Emissions and Sinks: 1990-2014," Report, U.S. Environmental Protection Agency, retrieved from: https://www3.epa.gov/ climatechange/Downloads/ghgemissions/US-GHG-Inventory-2016-Main-Text .pdf.

Eurostat (2013): "Electricity and Natural Gas Price Statistics," Retrieved February 18, 2014 from: http://epp.eurostat.ec.europa.eu/statistics_explained/index.php/ Electricity_and_natural_gas_price_statistics.

Feige, A., P. McAllister, And H. Wallbaum (2013): “Rental Price and Sustainability Ratings: Which Sustainability Criteria Are Really Paying Back?" Construction Management and Economics, 31, 322-334. 
FINANCE IDEAS (2014): “Dutch Residential Investments; in European Perspective," Report, Finance Ideas.

FRENCH, K. R. AND J. M. POTERBA (1991): “Investor Diversification and International Equity Markets," American Economic Review, 81, 222-226.

Fuerst, F. AND P. MCAlLister (2011): “Green Noise or Green Value? Measuring the Effects of Environmental Certification on Office Values," Real Estate Economics, 39, 45-69.

Gardiner, J., J. Heisler, J. G. KAllberG, And C. H. LiU (2007): “The Impact of Dual Agency,” The Journal of Real Estate Finance and Economics, 35, 39-55.

Geltner, D. M., N. G. Miller, J. Clayton, And P. M. A. Eichholtz (2014): Commercial Real Estate Analysis and Investments, OnCourse Learning, 3rd ed.

GiLmeR, R. W. (1989): “Energy Labels and Economic Search: An Example from the Residential Real Estate Market," Energy Economics, 11, 213-218.

GiRoud, X. (2013): "Proximity and Investment: Evidence from Plant-Level Data," The Quarterly Journal of Economics, 128, 861-915.

Golubov, A., D. Petmezas, And N. G. Travlos (2012): “When It Pays to Pay Your Investment Banker: New Evidence on the Role of Financial Advisors in M\&As," The Journal of Finance, 67, 271-311.

Goss, A. AND G. S. RoBerTS (2011): “The Impact of Corporate Social Responsibility on the Cost of Bank Loans," Journal of Banking and Finance, 35, 1794-1810.

HAN, L. AND S.-H. HONG (2015): “Understanding In-House Transactions in the Real Estate Brokerage Industry," Working paper.

Hansen, L. P., J. Heaten, And A. Yaron (1996): “Finite Sample Properties of Some Alternative GMM Estimators," Journal of Business and Economic Statistics, 14, 262-280.

Holtermans, R., N. KOK, AND D. Pogue (2015): “2015 National Green Building Adoption Index," Report, CBRE, retrieved from: http://www . cbre. com/rgrc.

Huberman, G. (2001): “Familiarity Breeds Investment,” Review of Financial Studies, 14, 659-680.

Hunter, W. C. And J. Jagtiani (2003): “An Analysis of Advisor Choice, Fees, and Effort in Mergers and Acquisitions," Review of Financial Economics, 12, 65-81.

Hyland, M., R. C. LyONS, AND S. LyONS (2013): “The Value of Domestic Building Energy Efficiency-Evidence from Ireland," Energy Economics, 40, 943-952.

IPCC (2014): “Climate Change 2014: Mitigation of Climate Change," Report, Intergovernmental Panel on Climate Change, retrieved from: https ://www .ipcc.ch/report/ar5/wg3/.

Ismail, A. (2010): “Are Good Financial Advisors Really Good? The Performance of Investment Banks in the M\&A market," Review of Quantitative Finance and Accounting, 35, 411-429. 
IVKovic, Z. AND S. WeIsBenNeR (2005): “Local Does as Local Is: Information Content of the Geography of Individual Investors' Common Stock Investments," The Journal of Finance, 60, 267-306.

JIN, G. Z. AND P. LESLIE (2003): “The Effect of Information on Product Quality: Evidence from Restaurant Hygiene Grade Cards," The Quarterly Journal of Economics, 118, 409-451.

- (2009): "Reputational Incentives for Restaurant Hygiene," American Economic Journal: Microeconomics, 1, 237-267.

Jud, D., T. SEAKS, AND D. WinKLeR (1996): “Time on the Market: The Impact of Residential Brokerage," Journal of Real Estate Research, 12, 447-458.

KAHN, M. E. AND N. KOK (2014): “The Capitalization of Green Labels in the California Housing Market," Regional Science and Urban Economics, 47, 25-34.

KAHN, M. E., N. KOK, AND J. M. Quigley (2014): “Carbon Emissions from the Commercial Building Sector: The Role of Climate, Quality, and Incentives," Journal of Public Economics, 113, 1-12.

Kalnins, A. And F. Lafontaine (2013): “Too Far Away? The Effect of Distance to Headquarters on Business Establishment Performance," American Economic Journal: Microeconomics, 5, 157-179.

KAnG, J.-K. And R. Stulz (1997): "Why is there a Home Bias? An Analysis of Foreign Portfolio Equity Ownership in Japan," Journal of Financial Economics, 46, 3-28.

Kleibergen, F. And R. PaAp (2006): “Generalized Reduced Rank Tests Using the Singular Value Decomposition," Journal of Econometrics, 133, 97-126.

KOK, N. AND M. JENNEN (2012): “The Impact of Energy Labels and Accessibility on Office Rents," Energy Policy, 46, 489-497.

KonRAD, K. And T. M (2014): “The Role of Economic Policy in Climate Change Adaptation," CESifo Economic Studies, 60, 32-61.

Kytle, B. And B. A. Hamilton (2005): “Corporate Social Responsibility as Risk Management: A Model for Multinationals," Working paper.

LANDier, A., V. B. NAIR, AND J. Wulf (2009): “Trade-Offs in Staying Close: Corporate Decision Making and Geographic Dispersion," Review of Financial Studies, 22, 1119-1148.

LAQUATRA, J. (1986): “Housing Market Capitalization of Thermal Integrity,” Energy Economics, $8,134-138$.

Laustsen, J. (2008): “Energy Efficiency Requirements in Building Codes, Energy Efficiency Policies for New Buildings," Report, International Energy Agency, retrieved from: https: //www.iea.org/publications/freepublications/publication/Building_Codes.pdf. 
LevitT, S. D. AND C. Syverson (2008): “Market Distortions When Agents Are Better Informed: The Value of Information in Real Estate Transactions," The Review of Economics and Statistics, 90, 599-611.

LEVY, H. AND M. SARnAT (1970): “International Diversification of Investment Portfolios," American Economic Review, 60, 668-675.

LiNG, D. C. AND W. R. ARCher (2010): Real Estate Principles: A Value Approach, McGraw-Hill Irwin, 3rd ed.

Ling, D. C., A. NAranjo, And M. Petrova (2014): “Search Cost, Behavioral Biases, and Information Intermediary Effects," Working paper.

MacInTOSH, W. (1996): “The PREI Research Metropolitan Market Survey," Report, Prudential Real Estate Investors.

Margolis, J. D., H. Elfenbein, And J. WAlsh (2007): “Does It Pay to be Good? A MetaAnalysis and Redirection of Research on the Relationship between Corporate Social and Financial Performance," Working paper.

Markowitz, H. (1952): “Portfolio Selection,” The journal of finance, 7, 77-91.

MCLaughlin, R. M. (1992): “Does the Form of Compensation Matter?: Investment Banker Fee Contracts in Tender Offers," Journal of Financial Economics, 32, 223-260.

MiAn, A. (2006): “Distance Constraints: The Limits of Foreign Lending in Poor Economies," The Journal of Finance, 61, 1465-1505.

Micelli, T., K. PANCAK, AND C. F. SiRmans (2000): “Restructuring Agency Relationships in the Real Estate Brokerage Industry: An Economic Analysis," Journal of Real Estate Research, 20, 31-47.

Oikonomou, I., C. BRoOKS, AND S. PAVELin (2014): “The Effects of Corporate Social Performance on the Cost of Corporate Debt and Credit Ratings," Financial Review, 49, 49-75.

PAlmer, K. AND M. WAlls (2014): “Does Information Provision Shrink the Energy Efficiency Gap? A Cross City Comparison of Energy Benchmarking and Disclosure Laws," Working paper.

PIVO, G. (2008): “Exploring Responsible Property Investing: A Survey of American Executives," Corporate Social Responsibility and Environmental Management, 15, 235-248.

Pivo, G. AND J. D. Fisher (2011): “The Walkability Premium in Commercial Real Estate Investments," Real Estate Economics, 39, 185-219.

RAU, P. R. (2000): “Investment Bank Market Share, Contingent Fee Payments, and the Performance of Acquiring Firms," Journal of Financial Economics, 56, 293-324.

Rosen, S. (1974): “Hedonic Prices and Implicit Markets: Product Differentiation in Pure Competition," Journal of Political Economy, 82, 34-55. 
Rutherford, R. C., T. Springer, AND A. YAVAs (2005): “Conflicts Between Principals and Agents: Evidence from Residential Brokerage," Journal of Financial Economics, 76, 627-665.

Rutherford, R. C. AND A. Yavas (2012): “Discount Brokerage in Residential Real Estate Markets," Real Estate Economics, 40, 508-535.

Schaffrin, A. AND N. Reibling (2015): “Household Energy and Climate Mitigation Policies: Investigating Energy Practices in the Housing Sector," Energy Policy, 77, 1-10.

SEASHOles, M. S. AND N. ZHU (2010): “Individual Investors and Local Bias," The Journal of Finance, 65, 1987-2010.

Servaes, H. AND A. TAMAYO (2013): “The Impact of Corporate Social Responsibility on Firm Value: The Role of Customer Awareness," Management Science, 59, 1045-1061.

Servaes, H. AND M. ZenNer (1996): “The Role of Investment Banks in Acquisitions,” Review of Financial Studies, 9, 787-815.

Sexton, S. E. AND A. L. Sexton (2014): “Conspicuous Conservation: The Prius Halo and Willingness to Pay for Environmental Bona Fides," Journal of Environmental Economics and Management, 67, 303-317.

Sharfman, M. P. AND C. S. Fernando (2008): “Environmental Risk Management and the Cost of Capital," Strategic Management Journal, 29, 569-592.

Sirmans, C. F., G. K. Turnbull, And J. D. Benjamin (1991): “The Markets for Housing and Real Estate Broker Services," Journal of Housing Economics, 1, 207-217.

SOLNIK, B. H. (1974): “An Equilibrium Model of the International Capital Market," Journal of Economic Theory, 8, 500-524.

STERn, N. (2008): “The Economics of Climate Change," American Economic Review, 98, 1-37.

Titman, S., S. TOMPAIDIS, AND S. TSYPlakov (2005): “Determinants of Credit Spreads in Commercial Mortgages," Real Estate Economics, 33, 711-738.

Turban, D. And D. Greening (1997): “Corporate Social Performance and Organizational Attractiveness to Prospective Employees," Academy of Management Journal, 40, 658-672.

Turnbull, G. K. AND J. Dombrow (2007): “Individual Agents, Firms, and the Real Estate Brokerage Process," The Journal of Real Estate Finance and Economics, 35, 57-76.

WACHTER, S. M. (1987): “Residential Real Estate Brokerage: Rate Uniformity and Moral Hazard," Research in Law and Economics, 10, 189-210.

WhiteheAd, C. AND K. J. SCANLON (2007): Social Housing in Europe, London School of Economics and Political Science.

Wiley, J. A., J. D. Benefield, And K. H. Johnson (2010): “Green Design and the Market for Commercial Office Space," The Journal of Real Estate Finance and Economics, 41, 228-243. 
YANG, S. AND A. YAVAS (1995): “Bigger is Not Better: Brokerage and Time on the Market," Journal of Real Estate Research, 10, 23-33.

Yoshida, J. AND A. Sugiura (2013): “The Effects of Multiple Green Factors on Condominium Prices," The Journal of Real Estate Finance and Economics, 50, 412-437.

Zheng, S., J. Wu, M. E. KAHN, AND Y. Deng (2012): “The Nascent Market for “Green” Real Estate in Beijing," European Economic Review, 56, 974-984. 



\section{Curriculum Vitae}

Rogier Holtermans was born on August 2, 1988 in Venray, the Netherlands. In 2010 he obtained a BSc. in International Business from Maastricht University. During his undergraduate studies, Rogier spent a semester abroad at the Handelshögskolan in Gothenburg, Sweden. After his undergraduate he continued his studies at Maastricht University in International Business, focusing on finance. In 2011 he successfully defended his master thesis on real estate finance and obtained his MSc.

Rogier joined the Finance Department of Maastricht University's School of Business and Economics as a researcher in early 2012 under the supervision of Piet Eichholtz and Nils Kok. He taught courses on Corporate and Venture Finance, Real Estate Finance, and Real Estate Investment and Valuation, and supervised students' master theses. In addition to his personal research, Rogier was involved in the management and acquisition of two projects for the European Commission and multiple research projects in cooperation with CBRE. During the doctoral program he held visiting researcher positions at: the U.S. Green Building Council in Washington, DC; the MIT Center for Real Estate in Cambridge, MA; and the Lusk Center for Real Estate at the University of Southern California, in Los Angeles, CA.

Rogier's research interests include the financial implications of information asymmetry and sustainability in real estate markets. One of his research papers has been published in the Journal of Economic Geography and he regularly presents his findings at academic conferences, most notably the Allied Social Sciences Association meetings, the American Real Estate and Urban Economics Association meetings, and the Financial Management Association meetings. Moreover, Rogier recently received the Real Estate Research Institute's 2017 dissertation research award.

Currently, Rogier holds a Postdoctoral Scholar - Research Associate position at the University of Southern California and is affiliated with the European Center for Corporate Engagement. 